\title{
Psychologisch onderzoek inzake arbeids(on)geschiktheid
}

Citation for published version (APA):

Lancée, W. H. J. (1988). Psychologisch onderzoek inzake arbeids(on)geschiktheid. [Doctoral Thesis, Maastricht University]. Rijksuniversiteit Limburg. https://doi.org/10.26481/dis.19881125wl

Document status and date:

Published: 01/01/1988

DOI:

10.26481/dis.19881125wl

Document Version:

Publisher's PDF, also known as Version of record

\section{Please check the document version of this publication:}

- A submitted manuscript is the version of the article upon submission and before peer-review. There can be important differences between the submitted version and the official published version of record.

People interested in the research are advised to contact the author for the final version of the publication, or visit the DOI to the publisher's website.

- The final author version and the galley proof are versions of the publication after peer review.

- The final published version features the final layout of the paper including the volume, issue and page numbers.

Link to publication

\footnotetext{
General rights rights.

- You may freely distribute the URL identifying the publication in the public portal. please follow below link for the End User Agreement:

www.umlib.nl/taverne-license

Take down policy

If you believe that this document breaches copyright please contact us at:

repository@maastrichtuniversity.nl

providing details and we will investigate your claim.
}

Copyright and moral rights for the publications made accessible in the public portal are retained by the authors and/or other copyright owners and it is a condition of accessing publications that users recognise and abide by the legal requirements associated with these

- Users may download and print one copy of any publication from the public portal for the purpose of private study or research.

- You may not further distribute the material or use it for any profit-making activity or commercial gain

If the publication is distributed under the terms of Article $25 \mathrm{fa}$ of the Dutch Copyright Act, indicated by the "Taverne" license above, 


\section{PSYCHOLOGISCH ONDERZOEK INZAKE ARBEIDS(ON)GESCHIKTHEID}

\section{PROEFSCHRIFT}

ter verkrijging van de graad van doctor aan de Rijksuniversiteit Limburg te Maastricht, op gezag van de Rector Magnificus, Prof. Dr. F.l.M. Bonke, volgens het besluit van het College van Dekanen, in het openbaar te verdedigen op vrijdag 25 november 1988 om 14.00 uur

door

Willhelm Heimen Jorgen Lancée

geboren te Amersfoort in 1948

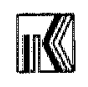

1988

Druk: Krips Repro Meppel 
Promotor: Prof.Dr. J.J.C.B. Bremer Compromotor: Dr. N.H. Groenman

Beoordelingscommissie: Prof.Dr. Ij. de Boorder (voorzitter) Prof.Dr. Ė.P. de Jong (Vrije Universiteit) Prof.Dr. M.A.j. Romme Prof.Dr. M. Timmer (Universiteit van Amsterdam) Prof.Dr. F.C.B. Wan wijmen 
"There are no disabled people. only people..." (Viscardi, 1957)

Aan mijn ouders, Marjan en Lige 
Uitgave: Psychologisch Adviesbureau Lancée $\mathbb{B} . V$. Setuarlo 47 Torenlaan I

$1815 \mathrm{CN}$ Alkmaar tea $\cdot 072-123923$ 9401 HN Mssen tel. $05920-12722$

Omslagtekening: J.W. Lancée

Gedrukt bij: Krips Repro Meppel, 1988 
Op deze plaats wil. ik allen danken voor de medewerking, de ondersteuning en het begtip, die zij mij direct en indrect hebben gegewen bij de cotstandkoming van dit proefschrift.

Mijn dank gat in de eerste plaats uit naar mijn promotor, prof.dr. J.J.C.B. Bremer. Joost, je wele kritische en constructieve kanttekeningen bij het manuscript zijn onontbeerlijk geweest. Ze betekenden voor mij. dat je in de mogelijkheid geloofde een retrospectief veldonderzoek, met al zijn methodologische voetangels en klemmen, een zodanig wetenschappelijk karakter te geven dat het an de eisen van een proefschrift zou kunnen voldoen.

Daanaast ben ik evenzoveel dank verschuldigd aan mijn co-pronotor, dr. N.H. Groenman. Nico, je was degene die iedere keer op de juiste momenten aanezig was, dan wel van je liet horen om mij te motiveren door te gan met het onderzoek en de beschrijuing ervan.

Vervolgens gat mijn dank uit naar drs. F.W.J. Otten woor zijn statistische creativiteit en analyses, nat drs. J.H.M. van Houtem voor de statistische verwerking van het onderzoeksmaterial en maar dr.ing. J.A. Schuerman voor zijn methodologische puntjes op de i.

Zonder de medewerking van het: Algemeen Burgerlijk Pensioenfonds (ABP), het Gemeenschappelijk Administratiekantoor (GAK) en de Gemeenschappelijke Medische Dienst (GMD) zou het onderzoek niet mogelijk zijn geweest.

Voor deze medewerking ben ik deze instanties erkentelijk en bedank ik bij dezen in het bijzonder voor hun bijdragen (in alfabetische volgorde): drs. R. van den Brand, adviserend geneeskundige ABP, drs. D.B. Kagenaar, medisch adviseur GAK, drs. G.B.M. Nagel, districtswerzekeringsgeneeskundige GMD, dhr. M. Passieux, hoofd stafbureau uitvoerende dienst GMD, drs. D. de Pater, voorheen medische adviseur GAK, nw. dra. M.L. SchipperKunz, adwiserend geneeskundige GAK, dhr. B.J. Schoutem, districtsarbeidsdeskundige GMD, drs. J.H.W.A. Schouten, districtsverzekerängsgeneeskundige GMD en dhr. A.J. Steenbergen, hoofdarbeidsdeskundige ABP.

Tevens ben ik voor hun kritische kanttekeningen dank verschuldigd aan mr. drs. M.W.P.J. Pompe, jurist en medisch adviseur Bedrijfsvereniging voor de gezondheid, geestelijke en matschappelijke belangen (BVG), en drs. B. Vos, directeur Bedrijfsereniging voor detailhandel, ambachten en vrouwen (Detam).

De wooronderzoeken, zoals deze zijn verricht door de werzekeringsgeneeskundigen drs. R. Smitshuijzen (Talmapenning, 1986) en drs. A. Wehman, zijt niet alleen van belang geweest voot het verzamelen van de verzekeringsgeneeskundige gegevens voor deze studie, matr hebben voor beiden tot een scriptie geleid in het kader van de opleiding tot verzekerimggeneeskundige.

Van eminent belang is de wijze geweest, warop de medewerkers wan mijn bureau te Alkmar en Assen mij de gelegenheid hebben gegeven dit proefschrift te schrijven, terwijl zij op respectabele wijze de voortgang van de dagelijkse werkzamheden hebben verzorgd. 
Mar de collega's drs. G. kratjenbrink en drs. J.H. Poelstra gat mijn wardering uit vook han inhoudelijke becommentariering van het manuscript.

Voor de taalkundige correcties bedank ik mw. drs. H.M. Lancée-Marco en mijn echtgenote M. k. F. Lancée-van Gestel, als ook dhr. E. Hoeksma voor zijn Engelse vertaling van de samenvating.

Een bijzonder dankwoord gatk wit naar mw. H. var Braam-Groot, mijn secretaresse, die nast har 'gewone werk' de witerste zorg heeft gedragen voor zowel de tekstverwerking als de lay-out. Hanneke, hiervoor ben ik je zeer erkentelijk.

Een belangrijke stirulang heb ik dagelijks ondervonden van mijn toen nog 4-jarig dochtertje Lize, die mij in de periode dat het manuscript moest worden geschreven iedere achtend om 5 uur heeft geroepen met: "Pappa kon, we moeten aan het werk!", warop ze, terwijl ik het manuscript schreef, bij.j mij.j ging zitten tekenen.

Zijn arbeidsethos en creativiteit dan toch erfelijk of is het een kwestie van "model 1.ing"?

In jeder geval laat mijn vader als ontwerper van de omslagtekening zien, dat een hoog arbeidsethos en creaciviceit goed kunen samengan. ook inhoudelijk is dit proefschrift daarvan een illustratie.

West-Graftijk, 1988 


\section{INHOUD}

OVERZICHT VAN SCHEMA'S, TABELLEN, FIGUREN EN GRAFIEKEN

b. 8 .

1. TNLETDING

1. Doel en opbouw van de studie 5

1.2 Het niet-strafrechtelijke forensisch psychologische referentiekader

1.3 Globale probleemstelling

1.4 Vraggstellingen

2. ARBEIDSONGESCHIKTHEID

2.1 Psychologische arbeids(on)geschiktheidsdiagnostiek wanuit hiscorisctu perspectief

2.2 De arbeidsongeschiktheidswetter

2.2.1 Geschiedenis van de arbeidsongeschiktheidswetten 28

2.2.2 Huidige arbeidsongeschiktheidsweten

2.3 Algemene praktijkgang bij de advies- en uitvoeringsorganen van de arbeidsongeschiktheidswetten

2.4 Beroepsmogelijkheden en rechtsgang

2.5 Overzicht van de procesgang bij de arbeids(on)geschiktheidsbeoordeling

3. ARBEIDSONGESCHIKTHEID EN PSYCHI SCHE STOORNISSEN

3.1 Arbeidsongeschiktheid in relatie tot ziekte en gebrek

3.2 Arbeidsongeschiktheid in verband met psychische stoor$n$ issen

3.3 Arbeidsongeschiktheid onder invloed van mat schappelijke en bedrijfsstructurele ontwikkel ingen

3.4 Arbeidsongeschiktheid en iatrogene invalidering

3.5 Arbeidsongeschiktheid en psychologische persoonskenmerken

4.1 Theoret ische achergronden

4.2 Indicatiestellingen voor psychologisch onderzoek

4.3 Protocol voor psychologisch onderzoek inzake arbe ids(on)geschikthe id

4.3.1 Voorbereiding voor het onderzoek

4.3.2 De anamese

4.3.3 Het psychometrisch onderzoek

4. 3.4 Het psychologisch beoordelingsproces en advies

4.3.5 Nabespreking en rapportage 
5. Specificering wan de probleemstelling 101

5.2 Onderzoeksvragen 104

5.3 Vorm en structur wan het onderzoek 107

5.4 Onderzaeksinstrumenten 110

5.5 Overzicht van de werklarende wariabelen en de criteri i un-variabele

5.6. Onderzoekspopulatie

5.6.1 Verdeling naar geslacht 117

5.6 .2 Verdeling naar leeftijd 119

5.6 .3 Verdeling naar opleidingsniveau $\$ 22$

5.7 Methode van datawerzameling 125

6. RESULTALEN EN DISCUSSIE

6. 1 De verstrekte psychologische arbeids(on)geschiktheidsadviezen

6.1.1 Discussie

6.2 (Dis)congruentie van de psychologische arbeids(on)geschiktheidsclassificaties en de beslissingen van de opdrachtgevers

6.3 Overzicht van het aantal beroepszaken 143

6.3.1 Discussie

6.4 Overzicht van de (on)gegrondverklaringen van 'voor beroep vatbare beslissingen"

6.5 Predictieve warde van de enkelvoudige psychologische persoonskenmerken met berrekking tot de psychologische arbeids(on) geschikthe idsclassificaties

6.6 Predictieve waarde van de enkelvoudige psychologische persoonskenmerken met betrekking tot het advies-overnamebeleid van de opdrachtgevers

6.6.1 Discussie

6.7 Predictieve waarde van de enkelvoudige pychologische persoonskentuerken met betrekking tot de beroepszaken 6.7 .1 Discussie

6.8 Predictieve warde van de enkelvoudige psychologische persoonskenmerken met betrekking tot de (on)gegrondverk laringen

6.9 Predictieve warde van de combinatie van psychologische persoonskenmerken met betrekking tot de psychologische arbeids (on)geschiktheidsclassificaties

6.10 Predictieve watade van de combinatie van psychologische persoonskenmerken met betrekking tot de beslissingen van de opdrachtgevers 
7.1 Voorlopige beslissingsregels voor de psychologische arbeids(on)geschiktheidsdiagnostiek

7.2 Een psychometrisch onderzoeksinstrumentarium voot de psychologische arbeids (on)geschiktheidsdiagnostiek

7.3 Vervolgonderzok

7.4 Opleiding en bijscholing

7.5 slotbeschouwing

A. Aantall uitkeringsgerechtigden op 31 december naar diagnose van 1981 tot en met 1985 (GMD Jaarverslag 1985)

$B$. Het antal blijvend arbeidsongeschiktverklaarden bij het $A B P$ in de periode 1981-1985, verdeeld naar ziektecategorie (ABP Jaarverslag 1985) 


\section{Schema's}

Schema I: Basisstructuur van de psychologische arbeids(on)geschiktheidsadvisering.

Schema 2: Overzicht huidige sociale verzekeringswetgeving en advies- en uitvoeringsorganen

Schema 3: Arbeidsongeschiktheidsbeoordeling heidsbeoordeling

Schema 5: Aspecten van de arbeids(on)geschiktheidsdiagnostiek

Schema 6: Beslissingsmodel voor de psychologische arbeidsconlgeschiktheidsbeoordeling

Schema 7: Rapportagemodel van psychologisch onderzoek inzake arbeids (on)geschiktheid

Schema 8: Structulur wan het onderzoek

Schema 9: Overzicht verklarende variabelen en criterium-variabele

\section{Tabellen}

Tabel 1: Niveau-indeling van werkaamheden volgens het ARBIclassificatiesysteem

Tabel 2: Overzicht arbeidsongeschiktheidscategorieën en witker ingspercentages

Tabel 3: Verdeling van de onderzoekspopulatie naar opdrachtgevers

label

4: Verdeling van de onderzoekspopulatie nar geslacht.

5: Verdeling nat leeftijdscategorieën van de onderzoeksen totale AAW/WAO-uitkeringsgerechtigde populatie met de diagnose 'psychische stoornissen"

Tabel 6: Verdeling van de onderzoekspopulatie nar opleidingsniveau

Tabe1 7: Percentuele verdeling nat opleidingsniveau van de onderzoekspopulatie in vergelijking met het tocal. aantal uitkeringsgerechtigden volgens de AAW en WAD en de werkende beroepsbevolking

Tabel 8: Percentuele verdeling arbeids (on)geschiktheidsadviezen nat leeftijd en geslacht

Tabel. 9: Percentuele verdeling arbeids(on)geschiktheidsadviezen naar opleidingsniveau en geslacht

Tabel 10: Overzicht van aantal werkloze mannen en vouwen mar schollingsniveau in relatie tot het aantal openstande vacatures in 1985

Tabel 11: Classificatiematrix wan psychologische adviezen en beslissingen van de opdrachtgevers betreffende arbejds(on) geschiktheid

Tabel 12: Percentuele verdeling van in beroep ( $B G+$ ) versus niet in beroep ( $\left.\mathrm{BG}^{-}\right)$gegane betrokkenen

Tabel 13: Overzicht arbeidsongeschiktheidsschattingen GMD en beroepszaken in Nederland over de periode 1981-1984 
Tabel 4 : Verdeling gegrond en ongegtond verka arde beroepszaken van op pychologisch advies gebaseerde beslissingen van de opdrachtgevers

Tabel 15: Overzicht van het ancial psychiaters en psychologen als adviseurs van de Raden van heroep in Nederland

Tabe1 16: Gemiddelden en t-toetsbevindingen betreffende psychologische persoonskenmerken en psychollogische classificatie: arbeidsgeschikt (AGt) versus arbeidsongeschikt $\left(A G^{-}\right)$

Tabel 17: Gemiddelden en t-toetsbevindingen betreffende de categorie betrokkenen met het psychologisch advies arbeidsgeschikt: door de opdrachtgevers overgenonen (OG+) versus niet overgenomen (OG-) adviezen

Tabel 18: Gemiddelden en t-toetsbevindingen betreffende de categorie betrokkenen die in beroep is gegaan (BG+) versus de categorie die niet in beroep is gegaan (BG-)

Tabe 1. 19: Overzicht gegrond- en ongegrondverklaringen van de landelijke en de onderzoekspopulatie

Tabel 20: Componentenladingen na varimax-rotatie van de verklarende variabelen

Tabel 2la: Verklarende variabelen in volgorde van lading op component $\|$ : psycho-emotionele labiliteit

Tabel 2lb: Verklarende variabelen in volgorde van lading op component 2: verbale intelligentie

Tabel 2lc: Verklarende variabelen in volgorde van lading op component 3: somatiseren

Tabel 2ld: Verklarende variabelen in volgorde van lading op component 4: psychopathologie

Tabel. 2le: Verklarende variabelen in volgorde van lading op component 5: performale intelligentie

Tabe 1 22: Geniddelden van de variabelen van de componenten en t-coetsbevindingen, verdeeld naar de psychologische classificatie: arbeidsgeschikt $(\mathrm{AG}+)$ versus arbeidsongeschikt ( $\mathrm{AG}-)$

Tabel 23: Het uhteindelijke resultat van stapsgewijze logistische regressie-analyse met als criterium-variabele de psychologische arbeids(on)geschiktheidsclassificatie en de predictor-variabelen

Tabel 24: De odds-ratio's van de relevante predictoren en de overeenkomst met $95 \%$ betrouwbarheids intervallen

Tabel 25: Gemiddelden en t-toetsbevindingen betreffende psychom logische persoonskenmerken var de beslissingen van de opdrachtgevers: arbeidsgeschikt ( $\mathrm{AG}+$ ) versus arbeidsongeschikt ( $\mathrm{AG}-$ )

Tabel 26: Gemiddelden van de variabelen van de componenten en $t-t o e t s b e v i n d i n g e n, v e r d e e l d$ a ar de beslissingen van de opdrachtgevers: arbeidsgeschikt ( $A G+)$ wersus arbeidsongeschikt $\left(\mathrm{AG}^{-}\right)$

Tabel 27: Overzicht van de relevante samengestelde componenten en afzonderlijke predictoren als criteria woor de psychologische arbeids(on)geschiktheidsclassificatie 


\section{Figuren}

Figuur I: Voorstelling van de balans cussen de draaglast en draagkracht bij de arbeidscongeschiktheidsbeoordeling

Figur 2: Percentueel overzicht van de verstrekte arbeids(on)geschiktheidsadviezen volgens categorie I tot en met VT, onderverdeeld naar geslacht

Figuur 3: Percentuele verdeling nar geslacht wan de psychologische arbeids(on)geschiktheidsadwiezen

Figur 4: Percentuele verdeling nat leeftija van de psychologische arbeids(on) geschiktheidsadviezen

Figur 5: Percentuele verdeling natr opleidingsniveau van de pychologische arbeids(on) geschiktheidsadviezen

Eiguur 6: Percentueel overzicht van de door de opdrachtgevers wel en niet overgenomen psychologische arbeids(on)geschiktheidsadviezen, verdeeld naar adviescategorieën

\section{Grafieken}

Grafiek I: Aantal uitkeringsgerechtigden wolgens GMD-diagnosecode W: "psychische stoornissen'; van decenber 1968, december 1981 tot en met decenber 1986

Grafiek 2: De ontwikkelingen van het verzuimpercentage in Nederm land over de periode 1959-1983; mannen resp. vrowwen

Grafiek. 3: Leefijdsopbouw van de onderzoekspopulatie en de totale populatie AAW/WAO-uitkeringsgerechtigden volgens GMD Jaarverslag $\$ 984$

Grafiek 4: Werdeling naar opleidingsniveau van de onderzoekspopulatie, total aantal witkeringsgerechtigden en werkende beroepsbevolking, volgens gegevens van het Central

Bureau voor de Statistiek (1987) 



\section{INLEIDING}

\section{I DOEL EN OPBOUH VAN DE SIUDIF}

De latste jaren worden steeds meer psychologen door verzekeringsgeneeskundigen van de advies- en uitvoeringsorganen van de arbeidsongeschiktheidswetgeving ingeschakeld om onderzoek te foen nat arbeids(on)geschiktheid (Broekhuis, 1986).

Ondanks de pleidooten van 0.a. De Cleen (1985) en Wehman (1986) ontbreekt tot nu toe echter de nodige evaluatie van he betekenis van psychologisch onderzoek voor de verzekeringsgeneeskundige arbeids (on) geschiktheidsbeoorm deling.

Voor een zorgvuldige beoordeling van arbeids(on)geschiktheid dient het verzekeringsgeneeskundig oordeel aan een antal kwaliteitseisen te voldoen (Timmer en Koten, 1984). Daarvoor kan in geval van vermeende psychische problematiek een psychologisch onderzoek noodzakelijk zijo. Tegen deze achtergrond kan de evaluatie van psychologisch onderzoek zich richten op de bijdrage die het levert an de besluitvoming inzake arbeids(on)geschiktheid door verzekeringsgeneeskundigen.

Naast een zo adequat mogelijke beoordeling van de arbeids(on)geschiktheid van betrokkenen is het onder meer de tak van verzekeringsgeneeskundigen om zoveel mogelijk beroepszaken te vermijden, ondat het proces van een beroepsprocedure pathogene elementen bevat en derhalve een invaliderende werking kan hebben (knepper en Den Ouden, 1988). Op basis daarvan kan vervolgens worden nagegaan in hoeverre mede op psychologisch onderzoek gebaseerde beslissingen van verzekeringsgeneeskundigen tot wermindering van het antal beroepszaken leiden.

Ingeval er wel sprake is van beroepszaken, is het tenslotte zinvol om te verifiëren in hoeverre de mede op het psychologisch onderzoek gebaseerde "voor beroep vatbare beslissingen" (VBVB'en) door de beroepsinstanties ongegrond worden verklaard.

Op deze wijze kan inzicht worden verkregen in de zinvolheid van het inschakelen van psychologen als externe adviseurs voor het verzekeringsgeneeskundig handelen en oordelen.

Verzekeringsgeneeskundigen blijken zich nogal eens door externe deskundi- 
gen te laten adviseren, alvorens zi tot een definitieve oordeelsworming komen (Groothofe, 1981 ).

In ca. 75\% van de 'psychische gevallen' laten verzekeringsgeneeskundigen zich informeren door de betrokken behandelars en hulpverlemers, dan wel vragen zij door middel van een expertise advies aan een psycholoog of psychiater. In ca. $25 \%$ van deze gevallen beslissen de verzekeringsgeneeskundigen zelfstandig (De Klerk e.a., 1986).

op grond vam de onderzoksgegevens van Knepper (1983) wit een analyse van 500 'schat ingszaken' voor de Raad van Beroep te Den Hag mag worden verondersteld dat de beroepsinstanties bij psychische problematiek in ongeveer $90 \%$ wan het totaal aantal te beoordelen gevallen een extern deskundige inschakelen.

De mate warin door zowel de advies- en uitwoeringsorganen als de beroepsinstanties een beroep wordt gedaan op psychodiagnostisch geschoolde deskundigen geeft aan hoe groot de behoefte is aan specifieke kennis op het gebied van de psychische arbeids(on)geschiktheidsdiagnostiek.

Tegelijkertijd is er toenemend sprake van keitiek op de adviezen van deze deskundigen (Vanmeulenbroeck, 1982; Timmer en Koten, 1982; knepper, 1985; Rujjzendaal, 1985; Tiburg en Gerritsen, 1985; Kottmann, 1987; Kabela, 1988).

Een analyse van de kritiek, die vooral de psychiatrische beoordelingen betreft, mar in het algemeen ook vam toepassing kan worden geacht op de psychologische beoordelingen, leidt tot de constateringen dat:

- er een gebrek is an duidelijkheid en inzicht in het beoordelingsproces;

- het ontbreekt aan eenduidige criteria op grond warvan de oordelen van de deskundigen tot stand komen;

- de beoordelingen en adviezen inhoudelijk nogal uiteenlopen en zelfs dikwijls tegenstrijcig zijn:

- de oordelen niet $z i j n$ uitgewerkt in termen wan reäle resterende arbeidsvermogens (lichamelijke belastbatrheid, psychische belastbarheid en be roepswardigheden).

Mede tegen de achtergrond wan deze kritiek wordt bij herhaling gewezen op de noodzaak van standardisering van het onderzoeksprotocol en op het daarbij gebruik maken wan gestandaardiseerde, genormeerde en gevalideerde 
psychometrische onderzoeksinstrumenten (Buys, 1984; Knepper, 1987; Koele, 1987; Kabela en Lancée, 1988). Standaardisering van het onderzocksprotocol heeft in dit verband betrekking op de procedure volgens welke de anamestische (kwalitutieve) en psychometrische (kwantitatieve) gegevens worden geinventariseerd om tot een oordeelsvorming inzake de arbeids(on)geschiktheid van betrokkenen te komer.

Een goed gestructureerd onderzoeksprotocol bevordert dat aan alle relevante gegevens aandacht wordt besteed (Farr, 1973). Daarbij verdient het a ambeveling een vaste set van variabelen te gebruiken en bij het verzamelen van dêze gegevens een vaste volgorde aan te houden en gebruik te maken van psychometrische onderzoeksmethoden (Roe, 1983).

Psychometrisch onderzoek is een onderdeel van de 'objectiwerende psychologie' (Bonarius, 1988), waarbij gebruik word gemakt van gestandardiseerde, genormeerde en gevalideerde onderzoeksinstrumenten. Met psychometrische onderzoeksinstrumenten worden in dit verband wetenschappelijke onderzoeksmethoden bedoeld, warmee volgens een systematische procedure wordt onderzocht in welke mate et empirisch-theoretisch gedefinieerde psychologische persoonskenmerken bij de onderzochte persoon aanwezig zijn (Drenth, 1975).

Kenmerkend voor psychometrisch onderzoek is dat de onderzoeksopgaven (stimuli) zijn gestandaardiseerd en zodanig in het onderzoek worden gepresenteerd, tat aan de reacties (die dikwijls het karakter van een keuze hebben) gevolgtrekkingen over één of ander persoonskenmerk kunnen worden verbonden.

Bij psychometrisch onderzoek zijn niet alleen de aabiedingen van on derzoekstimuli, maar ook het toekennen van scores aan bepalde reacties aan vaste regels gebonden. Gewoonlijk worden de daardoor verkregen ruwe scores via zogenaande normen (transformatieformules of tabellen) in gestandaardiseerde scotes ongezet. Door gebruik te maken wan gestandardiseerde psychometrische onderzoeksmethoden, warvan de validiteit en bet rowwbarheid bekend zijn (Visser e.a., 1982), worden onderzoeksbevindingen vergelijkbar, wordt iedereen aan de hand van zoveel mogelijk dezelfde regels beoordeeld en kunnen analyses van het beoordelingsproces worden gemaakt.

Een analyse van het beordelingsproces en explicitering van de beslissings- 
criferia geeft inzicht in de oordeelsworming en makt standaardisering van een onderzoeksprotocol mogelijk.

Door midel van onderzok kunnen verbeteringen in bet onderzoeksprococol worden asngebracht en kan de samenstelling van de onderzoeksinstrumenten worden bijgeste $\mathbb{d}$. Met duidelijke aanbevelingen en richtijnen kan een belangrijke stap worden gezet in de richting wan meer eenduidigheid in en vergel ijkbaarheid van de onderzoksprotocollen, de psychometrische onderzoeksprograma"s en de verslagleggingen. Dit kan de objectiviteit an rechtsgelijkheid in oordeelsvorming met betrekking tot arbeids(on)geschiktheid ten goede komen.

Vanuit deze visie richt dit onderzak zich op de bepaling van de 'in strumentele utiliteit" (De Groot, 1972) ofwel de doeltreffendheid en 'objectiverende' gebruikswarde van een antal bestaande psychometrische ondermoeksinstrumenten in het kader wan de psychologische arbeids(on)geschiktheidsdiagnositiek.

Het doel van deze studie kan dan ook worden omschreven als: het maken wan een analyse van in de praktijk verstrekte psychologische arbeids(on)geschiktheidsadviezen, warbi j wordt nagegaan:

le. in welke mate psychometrische onderzoeksbevindingen bijdragen tot de classificatie van arbeidsgeschikten versus arbeidsongeschikten;

2e. met behulp wan welke psychometrische instrumenten de psychologische oordeelsvorming net betrekking tot arbeids(on)geschiktheid geobjectiveerd en eventueel verbeterd kan worden.

Daartoe vindt een evaluatie plaats van een antal psychologische onderzoeken, zoals deze zijn verrüht in het kader van de arbeidsongeschiktheidswetgeving op verzoek van de advies- en witvoeringsonganen (CAK, GMD en ABP) i.ü de periode 1981 cot en met 1984.

- In de eerste plats wordt geînventariseerd welke psychologische arbeids(on)geschiktheidsadwiezer an de desbetreffende instanties zijn verstrekt.

- Vervolgens wordt geanalyseerd in welke mate bepaalde psychometrische onderzoeksgegevens een bijdrage leveren an de psychologische oordeelsvorming (classificaties) inzake arbeids(on)geschiktheid en in het bijzonder hoe op grond van psychometrische gegevens een onderscheid 
cussen arbeidsgeschikten en arbeidsongeschikten kan worden gemakt.

- Ter bepaling van de instrumentele utiliteit van de toegepaste instrumenten wordt nagegaan in hoeverre de desbetreffende psychologische adwiezen daadwerkelijk door de opdrachtgevende instanties zijn overgenomen.

- Tenslotte wordt het oordeel van de beroepsinstanties bij deze evaluatie betrokken, voor zover de psychologische adviezen en rwede daarop gebaseer de "voor beroep vatbare beslissingen' (VBVB'en) van de opdrachtgevers tot beroepsaken hebben geleid.

Op deze wijze kan de wetenschappelijke en matschappelijke relevantie van psychometrische onderzoeksmogelijkheden naar arbeids(on)geschiktheid worden bepald. Alvorens op de verdere uitwerking hiervan in te gan, volgt nu eerst een overzicht wan de opbouw wan deze studie.

Na een korte beschrijuing van het niet-strafrechtelijke forensisch psychologische referentiekader warbinnen psychologisch onderzoek inzake arbeids(on)geschiktheid plaatsvind (1.2), eindigt hoofdstuk I met de formulering van de globale problemstelling van deze studie (1.3) en de daaraan gerelateerde onderzoekswaagstellingen $(1.4)$.

In hoofdstuk 2 wordt vanuit historisch perspectief het ontstaan en de ontwikkeling van de 'sociale verzekeringspsychologie' beschreven (2.1). Vervolgens wordt een globale beschrijwing gegeven van de ontwikkeling wan de arbeidsongeschiktheidsweten en worden de actuele wetellijke criteria van arbeidsongeschiktheid aangegeven (2.2). In paragraaf 2.3 kom de werkwijze van de adviserende en witwoerende instanties met betrekking tot het beoordelen van arbeids(on)geschiktheid aan de orde. Vervolgens wordt kort ingegaan op de beroepsmogelijkheden wan degenen die zich njet kumen ver enigen met de mate van vastgestedde arbeidsongeschiktheid $(2.4)$.

Het hoofdstuk eindigt met een overzicht van de procesgang, zoals deze in het algemeen verloopt bij de beoordeling van de arbeidsongeschikthejd door respectievelijk de adviserende, witvoerende en rechterlijke instanties $(2.5)$.

In hoofdstuk 3 wordt het begrip arbeidsongeschuktheid wegens psychische stoornissen in relatie gebracht met de begrippen ziekte en gebrek (3.1). $\mathbb{E r}$ wordt een overzicht gegeven van het toenemend aantall mensen dat op grond van psychische stoornissen een witkering krijgt krachtens de thans 
geldende arbeidsongeschikcheidswetcen $(3,2)$. Op basis van liceraturstudie wordt en overzicht gegeven van de factoren die op macro-, meso- en microniveau yan invloed kunen zijn op het ontstaan van psychische arbeidsongeachikthex $(3.3$ tot en met 3.5$)$.

In hoofdstuk 4 komen de theoretische achtergronden van de psychologisch arbeids(on)geschiktheidsdiagnostiek aan de orde. In aansluiting daarop wordt een overzicht gegeven van de indicatiestellingen voor psychologisch onderzoek nar arbeids(on)geschiktheid.

Het hoofdstuk eindigt met een overzicht van een protocol voor psychologisch onderzoek inzake arbeids ong geschiktheid.

Hoofdstuk 5 betreft de beschrijuing van de opzet en de witvoering van het evaluatieve gedeel te var deze studie.

De resultaten van en de discussie over de onderzoeksbevindingen worden in boofdstuk 6 weergegeven.

In hoofdstuk 7 worden de conflusies uit de onderzoeksbevindingen getormuleerd (7.1 en 7.2) en worden tevens een aantal anbevelingen gedaan met betrekking tot vervolgonderzoek (7.3) en (post-) doctorale scholing in de sociale verzeketingspsychologie $(7.4)$.

Tot slot (7.5) wordt expliciet aangegeven dat arbeidsongeschiktheid ten gevolge van psychische stoornissem niet alleen een individueel persoonsgebonden probleem is, mar tevens is gerelateerd aan matschappelijke, bedrijfstructurele en social-economische problemen. Het proefschrift eindigt met een samenvating in de Nederlandse en Engelse taal.

\subsection{HET NIET-STRAFRECHTEL IJKE FORENSISCH PSYCHOLOGISCHE REFERENTIEKADER}

In algemene zin kan dit evaluatiemonderzoek worden beschouwd als aen zogenaand 'kwalltatief onderzoek' (Van Zuuren" 1987) van een specifigke praktijkgang binnen het niet-strafrechtelijke forensisch psychologische werkveld. Het betreft een analyse van psychologische onderzoeken en adviezen inzake arbeids(on)geschiktheid van wettelijk verplicht ver zekerdan.

op grond van de huidige onschrijuing van het juridische begrip 'arbeidsongeschikheid", betrekking hebbende op arbeidsonvermogen ten gevolge van 
ziekten of gebreken $(2.2 .2)$, lat de wet toe dat psychologen worden geraacpleegd in het kader van de arbeids(on)geschiktheidsbeoordeling.

Deze beoordeling betrett mensen die wegens psychische en/ot lichanelijke klachten en symptomen zich niet in staat achten of niet in stat geacht worden om te werken en daarom een beroep doen op een uitkering krachtens de Ziektewet (ZW), respectievelijk de Algemene Arbeidsongeschiktheidswet (AAW) en de Wet op de Arbeidsongeschiktheidsverzekering (Who).

Zij die voor pensioen verzekerd zijn bij het Algemeen Burgetlijk PensioenFonds ( $A B P$ ) maken in geval van een blijvende arbeidsongeschiktheid voot hun eigen werk aanspraak op een invaliditeitspensioen (IP) in het kader van de ABP-wet.

In geval van tijdelijke arbeidsongeschiktheid behoudt deze categorie verzekerden het recht op inkomen, in de vorm van salaris, respectievelijk ziekengeld ten laste van de werkgever.

Actief dienende militairen en medewerkers van de Nederlandse Spoorwegen zijn tegen arbeidsongeschiktheid verzekerd krachtens respectievelijk de Algemene Militaire Pensioenwet (AMP) en de Spoorwegpensioenwet. ook in het kader van de uitvoering van deze wetten kan een psychologisch arbeids(on)geschiktheidsonderzoek wenselijk zijn.

op grond van de samenstelling van de onderzoekspopulatie van deze studie (zie 5.6) wordt alleen nader ingegaan op psychologisch onderzoek naar arbeids(on)geschiktheid in het kader van de $Z W$, AAW, WAO en ABP-wet.

Wat betreft de ZW, AAW, WAO en ABP-wet kan een psychologisch onderzoek naar arbeids(on)geschiktheid plaatsvinden in opdracht van respectievelijk de Gemeenschappelijke Medische Dienst (GMD), het Gemeenschappelijk Administratiekantoor (GAK) voor een aantal (16) niet zelf-zdministrerende bedrijfsverenigingen, de zelf-administrerende bedrijfsverenigingen ( $\left.2 A-B V^{\prime} e n\right)$ en het Algemeen Burgerlijk Pensjoenfonds (ABP).

Een dergelijk onderzoek kan tevens worden verricht in opdracht van de beroepsinstanties die belast $z i j n$ met de rechtsprak inzake de sociale zekerheidswetgeving: de Raden van Beroep, de Ambtenarengerechten en de Centrale Raad van Beroep.

Psychologisch onderzoek inzake arbeids(on)geschiktheid ten behoeve van de uitvoering van de sociale verzekeringswetgeving en de sociale verzekerings- 
rechtsprak betreft een betrekkelijk recent toepassingsgebied van de voor dit werkweld relevante delen van de kinische, medische, arbeids- en beroepskeuzepsychologie. Gerelateerd andit specifieke toepassingsgebied kan er worden gesproken wan 'sociale verzekeringspsychologie". op grond wan het adminftratief-rechtelijke kader, warbinnen psychologisch onderzoek van verplicht verzekerden plaasvindt, ressorceert een dergelijk onderzok onder de niet-gtrafrechtelijke forensische psychologie.

forensisch is afgeleid van 'het forum', de centrale marktplats war vroeger recht werd gesproken ten tijde dat de psychologie overigens als wetenschap nog niet bestond (Boon, 1984).

Het actuele forensische aspect van psychologisch onderzoek ligt in de onderbouwing van de juridische beoordeling van de arbeids(on)geschiktheid van mensen, die daarvoor op grond van vermeende ziekten of gebreken in aanmerking komen.

In het algemeen geldt, dat in het kader van de arbeidsongeschiktheidswetgewing rechtstreeks door de adviserende, uitwoerende en beroepsinstanties een onderzoek bij een psycholoog kan worden aangevraagd. Alleen in geval van een beroepszaak betreffende geschillen var geneeskundige aard over het al of niet (voort-)bestan van arbeidsongeschiktheid uit hoofde van de Ziektewer is de rechter, ingevolge artikel $\| 3.5$ van de Beroepswer, verplicht on advies te vragen aan een vaste medisch-geschoolde deskundige. Aam elke Raad van Beroep zijn vaste deskundigen verbonden, die de hoedanigheid van arts beziccen (Beroepswet, artikel 131). Zij worden telkens voor één kalenderjaar aangesteld op voordracht van de voorzitter van de Raad van Beroep. De benoeming geschiedt door de Minister van Justitie, nadat deze advies heeft ingewonnen bij de Koninklijke Nederlandsche Maatschappij tot bevordering der Geneeskunst en de geneeskundige hoofdinspecteur van de volksgezondheid (Beroepswet, artikel 132).

Een vaste deskundige kan zich in geval van psychische problemen laten bijstan door een psycholoog. De psychologische onderzoeksbevindingen worden dan betrokken bij de vaststelling van het advies van de vaste deskundige en daarmee bij de rechterlijke oordeelsworming.

Ingeval er door de psycholoog als adviserend deskundige rechtstreeks op verzoek van de voorzitter van én der administratieve rechtscolleges een 
onderzoek naar arbeids(on)geschikcheid wordt verricht, is er sprake van een directe relatie met betrekking tot de rechtspleging. Het psychologisch rapport en het advies kunnen in $20^{\prime} \mathrm{n}$ geval mede de basis voor de oordeelsvoming van de desbetreffende beroepsinstantie wormen.

Voor zover de beslissingen van de advies- en uitvoeringsorganen mede zijn gebaseerd op psychologische adviezen, is er sprake wn een indirecte bijdrage aan de rechtspleging inzake de sociale zekerheidswetgeving.

Tegen 'voor beroep vatbare bes lissingen', ook die welke (mede) berusten op een psychologisch advies, kunnen betrokkenen bij de administratief-recholijke colleges beroep aantekenen.

Hoewel niet als direct betrokken 'partij' heeft de psycholoog, evenals andere adviserende deskundigen, met beroepspocedures te maken, ondat:

- de advies- en witvoeringsorganen voor hun 'contra-menorie' in het kader van een beroepszak een nadere toelichting, motivering en beargumentering van een aan hen uitgebracht advies of commentaar op een 'contramex pertise' door de psycholoog moodzakelijk achten;

- de psycholoog bij een beroepszaak betrokken kan worden wanneer de rechter het noodzakelijk acht on een nadere toelichting op het verstrekte psychologische advies, dan wel commentar op door derden verricht onderzoek, te vragen.

In het algemeen mag worden verondersteld dat uitspraken van de rechter in dezen een belangrijke invloed kunnen uitoefenen op het adviesbeleid van de psycholoog.

Voor een meer uitgebreide beschrijving wan de platsbepaling van de psychologische arbeids(on)geschiktheidsdiagnostiek en de positie van de psycholoog als adviseur van de advies-, witvoerings- en beroepsinstanties wordt verwezen naar Koenraadt en Pach (1988).

Het onderzoeken en adviseren inzake arbeidg(on)geschiktheid binnen het niet-strafrechtelijke forensisch psychologische referentiekader vereist van de deskundige dat hij of zij procedureel en inhoudelijk an bepalde eisen, voorwaarden en verwachtingen voldoer. Hierop wordt in hootdstuk 4 nader ingegaan. 
Het verrichten van psychologisch onderzoek nat arbeids(on)geschiktheid in het kader van de sociale wetgeving vindt plats op verzaek van instanties die datroe krachtent de wet zijn bevoegd.

De opdracht tot extern onderzoek van verzekerden door derden wordt vanuit een 'werticale relatie" gegeven (zie Beroepsethiek voor Psychologen; Mederlands Institut van Psychologen, 1987).

In deze sudie zijn de opdrachtgevers verzekeringsgeneeskundigen van de advies-en uitvoeringsorganen van de arbeidsongeschiktheidswetten.

De werkzamheden van deze verzekeringsgeneeskundigen hebben als zodanig grotendeels een wetsuitvoerend karakter (Holthuis, 1980b) en bestan uit:

- het vaststellen van de rechtmatigheid van de aanspraken op een uitkering krachtens de desbetreffende arbeidsongeschikthe idswetten;

- het beoordellen van de prognose met bet rekking tot genezing en werkhervatting:

- het eventueel vaststellen van een hersteldatum;

- het treffen van matregelen om blijvende arbeidsongeschiktheid te voorkomen, dan wel zoveel als mogelijk te beperken (Den Bieman, 1987).

De verzekeringsgeneeskundige dient de arbeidsgeschiktheid aamemelijk te maken door, eventueel met behulp van extern deskundig onderzoek, vast te stellen dat er bij betrokkene geen arbeidsbelemerende ziekteverschijnselen of gebreken (meer) aanwezig zijn. Als zodanig dient er een positief bewijs te worden geleverd dat betrokkene, ondanks eventuele klachten en symptomen, voldoende dragkracht en beroepsvaardigheden heeft on te kunen werken. Derhalve ligt de 'bewijslast" wan arbeidsgeschiktheid bij de darover oordelende verzekeringsgeneeskundige (Philipsen, 1979). Diens beoordeling moet wettelijk op medische argumenten berusten, passen binnen het social-wettelijk kader en bestand zijn tegen een toetsing door (deskundigen van) de (Centrale) Raad van Beroep.

Dit vormt de achtergrond wan waruit verzekeringsgeneeskundigen hun vraagstellingen Formuleren en opdrachten geven tot extern deskundig onderzoek. Zij verzoeken de deskundige vragen te beantwoorden met betrekking tot de arbeids(on)geschiktheid van een derde, krachtens de wet verzekerde persoon: betrokkne, belanghebbende of verzekerde genoend. 
De verticale opdrachtrelatie en de sociaal-wettelijhe context zijn bepalend en richtinggevend woor de verzekeringsgeneeskundige vrabgrellingen en daarmee voor het deskundig onderzoek ter zake.

De belangrijkste redenen voor verwijzing naar een psycholoog zijn vragen van de verzekeringsgeneeskundige omtrent de psychische belastbarkeid en geschiktheid van betrokkene on bepalde arbeid te kunnen verrichten.

De vraagstellingen van werzekeringsgeneeskundigen watrop door middel van psychologisch onderzoek een antwoord wordt verwacht, centreren yich dan ook rond de volgende individugebonden themata:

- Wat is de psychische gesteldheid van betrokkene in relatie tot de anbeids(on) geschiktheid?

- Indien en voor zover betrokkene als arbeidsongeschikt noet worden beschouwd, wat zijn dan de specifieke psychische stoornissen en darmee samenhangende beperkingen in 'belastbarheid en beroepsvararigheden' (Timmer, 1985)?

- Indien en voor zover betrokkene als arbeidsongeschikt moet worden beschouwd, is dit dan van blijvende of tijdelijke aard (prognose)?

- Indien betrokkene voor eigen of vergelijkbaar werk als arbeidsongeschikt moet worden beschouwd, voor welke werkzamheden is hij/zij dan wel geschikt en is daarvoor om-, her- of bijscholing nodig?

- Wat is de prognose na om-, her- of bijscholing ten aanzien van het herstel van de arbeidsgeschiktheid?

- Is er een indicatie voor psychotherapeut ische behandeling of begeleiding?

- Wat is de prognose na een thetapeutische behandeling of begeleiding ten aanzien van het herstel van de arbeidsgeschiktheid?

- Was er reeds sprake van arbeidsongeschiktheid bij aanvang der verzekering of was het op dat moment te verwachten dat betrokkene binnen een half jaar wegens psychische stoornissen zou uitvallen?

De beantwoording van voornoemde vraggtellingen vereist de toepassing van een bepald onderzoeksprotocol en specifieke onderzoeksinstrumenten, gericht op de beoordeling van:

- de verhouding tussen enerzijds de psychische belastbaarheid en beroepsvaardigheden en anderzijds de psychische belasting, voortkomend vit de werkzaamheden en werkomstandigheden, waraan volgens de opdrachtgevers 
moec worden gerefereerd (eigen beroep en/of "referentieberoepen" en darbij behorende "werkutvoetingseisen". Timmer, 1985).

- de andezighejd van arbejdsbelemerende psychische, psycho-fysiologische en gedragsmat ige stoornissen;

- het ontstan, beloop en gebrek aan herstel van voornoemde stoornissen, wardoor er gprake kan $z$ ijn van arbeidsongeschikrheid.

In het algemeen betreft de psychologische diagnostidk een proces wan beslissingen in onzekere situaties, warbij zowel subjectieve als objectieve gegevenheden een rol spelen (Be Bruyn, 1988). De methodologische grondligut kan worden getypeed als een diagnostisch-prognostische cyclus (Westmeyer, 1972), welke uitmondt in een diagnose, een classificatie of een kans-uitsprak.

Bij de beoordeling wan de arbeids(on)geschiktheid wordt door de psycholoog gebruik gemakt wan anannestische (kwallitatieve) en psychometrische (kwantitatieve) gegevens.

Op grond van de interpretatie van deze gegevens komt de psycholoog-adviseur tot een oordeel inzake de arbeids(on)geschiktheid van betrokkene. Dit oordeel gat als advies nar de opdrachtgever van het psychologisch onderzoek.

De basisstructur van de psychologische arbeids(on)geschiktheidsadvisering is in schema I vereenvoudigd weergegeven.

Schema 1: Besisstructur van de psychologische arbeidstongeschiktheidsadvisering

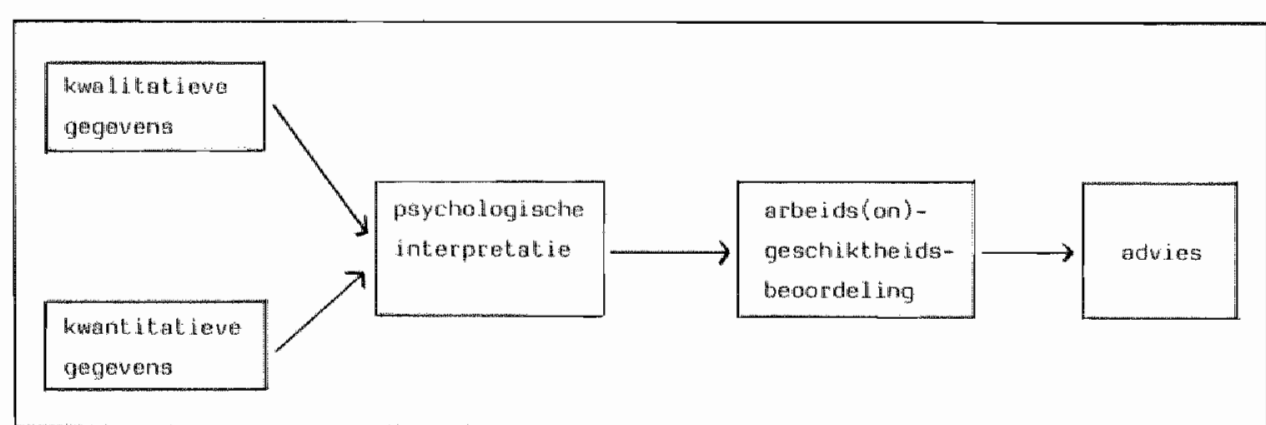

De kwalitatieve gegevens betreffen de anamestische inventarisatie van de 
psychische belasting (dragglast) en de belastbartheid (dragkrache) in termen wan de subjectieve betekeniswerlening van betrokkene an:

- de klachter en symptomen, wardoor betrokkene zich niet in stat voelt om te werken, respectievelijk op grond waarvan dege een beroep doet op de arbeidsongeschiktheidsrege ingen;

- het ontstaan en beloop van de klachten en symptomen, gerelateerd aan de genoten behandelingen en hun effecten;

- schokkende gebeurtenissen en traumat ische ervaringen ( 1 i fe-events);

- de levensloop en ontwikkelingsgang;

- de gevolgde scholing en hec arbeidsverleden;

- verwachtingen, vexplichtingen en verantwoordelijkheden, woortkomend wit de werk- en privésituatie.

De kwantitatieve gegevens zijn de getalsmatige resultaten wan betrokkene op bepalde psychometrische cests, persoonlijkheids- en screeningsuragenlijsten, die als zodanig een gestandaardiseerd en genormeerd beeld geven van de psychische belastbarheid en beroepsvardigheden. Deze hebben als samengestelde factoren (Roe, 1983) betrekking op:

- cognitief-intellectuele functies;

- kenis en vardigheden;

- karakterstructuur;

- emotionaliteit en lichamelijke gevoelens;

- persoonlijke warden, normen, doelen, instelling en motivatie;

- affiniteiten;

- gedrag en anpassingsvermogen.

Omdat het hier om een combinatie van 'scores' op een aantal psychologische persoonsvariabelen gat, kan er worden gesproken van de 'psychonectische belastbaarheid en beroepswaardigheden' (Hofstee, 1984).

De psychologische interpretatie kan worden beschouwd als ean mediërend proces, warbij op grond van een conglomeraat van feiten, kennis, theorew tische inzichten en klinische ervaring met betrekking tot de kwalitaticue en kwantitatieve gegevens door de psycholorg de verhouding tussen de psychische belasting en belastbarheid van betrokkene wordt angegeven. Dit wordt geformuleerd in termen van resterende psychische belastbarheid en beropsvardigheden. 
De prychologische beoordeling van de arbeids(on)geschiktheid kont rot stand door de geconstateerde resterende psychische belastbaarheid en beroepsaardigheden te relateren aan de eigen en/of andere passende en in billijkheid op te dragen werkzamheden, zoals deze door de opdrachtgevers vanuit de wettijke kaders woten aangegeven.

op grond van deze beordeling wordt betrokkene door de psycholoog als arbeidsgeachikt of arbeidsongeschikt geclassificeerd. De psychologische classificatie wordt als advies aan de opdrachtgever uitgebracht. Mede op basis daurvan kan de opdrachtgever de beslissing nemen wat betreft de waststelling van de mate van arbeids(on)geschiktheid van betrokkene.

Theneinde de vergelijkbarheid tussen psychologische adviezen inzake arbeids(on)geschiktheid en de beslissingen van de opdrachtgevers daaratcent mogelijk te maken, kunnen de psychologische onderzoeksbevindingen betrefw fende de resterende psychische belastbarheid en beroepsvardigheden worden 'getransformeerd' naar een indeling van adviescategorieën, zoals deze in de praktijk van de advies- en uitvoeringsorganen worden gehamceerd (Wehman, 1986; Smitshuijzen, 1987).

Daabij dient expliciet te worden opgemerkt dat de psychologische arbeidsongeschiktheldsbeoordeling op basis van een ander besissingsmodel en andere criteria tot stand komt dan door de advies en uitvoeringsorganen worden gehanteerd.

Psychologische beoordelingen en uitspraken in termen van 'arbeids(on)geschiktheid' zijn het resultaat van een afweging tussen de geconstateerde resterende psychische belastbaarheid en beroepsvardigheden in relatie tot de belasting, voortkomend uit de werkzamheden waraan volgens de opdrachtgevers moet worden gerefereerd. Daarbij wordt rekening gehouden met de eventuele lichamelijke beperkingen, zoals die door de verzekeringsgeneeskundige zijn arangegeven. Op grond van de psychisch en somat isch geconstateerde resterende arbeidswermogens, uitgewerkt in termen van beroepsvardigheden, persoonlijkheidskenmerken en lichamelijke kenmerken (Timmer, 1985), vindt door de arbeidsdeskundige, in samenspraak met de wetstechnisch-beoordelar, de juridisch-economische beoordeling plaats (Haak, $1970)$

Deze juridisch-econorische beoordeling riche zich op het bepalen van derechten op een uitker ng, warvan de hoogte mede afhankelijk is van de res- 
terende "verdiencapaciteit". De mate wan pastgestelde resterende werdiencapaciteit en de hoogte van het latst genoten inkonen zijn bepalend voor de arbeidsongeschiktheidscategorie warin iemand wordt ingedeeld.

In verband met het hanteren wan verschillende beoordelingscriteria besta de mogelijkheid dat er een discongruentie is tussen de psychologische arbeidsongeschiktheidsbeoordeling en de witeindelijke wettelijke arbaids(on)geschiktheidsclassificatie.

Ter adstructie van het verschil in beoordelingsprocessen wordt een apate subparagraf (2.3) gewijd aan de wijze warop de advies- en uitvoeringsorganen te werk gaan bij het bepalen van de arbeids(on)geschiktheid.

In hoofdstuk 4 wordt nader ingegaan op de theoretische achtergronden en het uitvoeringsprotocol van de psychologische arbeids(on)geschiktheidsdiagnostiek.

De psychologische arbeids(on)geschiktheidsdiagrostiek berust op een diagnostisch proces van beslissingen. Op grond van kwalitatieve en kwantitatieve gegevens worden in een bepalde volgorde van denkstappen en keuzemonenten beslissingen genomen, die leider tot een besluit inzake de resterende psychische belastbaarheid en beroepsvardigheden.

Gezien het oogmerk van deze studie: bepaling van de 'objectiverende relevantie" van gestandaardiseerd, genomeerd en gevalideerd psychologisch onderzoek als hulpmiddel bij de psychologische arbeidsongeschiktheidsbeoordeling, worden de anamestische (kwalitatieve) gegevens njet in dit onderzoek betrokken, al hebben ze wel hun invloed gehad op de 'klinische oordeelsvorming".

Vanut dit perspectief richt dit onderzoek zich dan ook specifiek op de zogenaande 'statistische oordeelsvorming', dat wil zeggen op het vaststellen van de nate warin kwantitatieve gegevens van bepalde psychometrische onderzoeksinstrumenten van invloed zijn op de psychologische arbeids(on)geschiktheidsclassificatie.

Op grond darvan wordt antwoord gezocht op de vraag:

In hoeverre kumen mensen, die in principe op lichamelijke gronden wel arbeidsgeschikt, maar mogelijk wegens psychische stoornissen niet arbeidsgeschikt zijn, met behulp van psychometrische onderzoeksinstrumenten worden onderscheiden in arbeidsgeschike en arbe idsongeschikt? 
Aan deze probleemstelling kunen de volgende evaluatieve aspecten worden ondersweiden:

1e. vaststelling van de predictieve (voorspellende) warde van de toegepaste psychometrische onderzoeksgegevens, arzonderlijk en in combinatie, met betreking tot de psychologische arbeids(on)geschiktheidsclassificatie arbeidsgeschikt versus arbeidsongeschikt (psychologische adviezen):

2e. vaststelling an de instumentele utiliteit in bredere zin van de gehanteerde psychometrische instrumenten met betrekking tot de psychologische advisering in relatie tot de besluitvorming van de opdrachtgevers, betrokkenen en beroepsinstanties;

3e. vaststelling wan (voorlopige) beslissingsregels op grond van de geconstateerde predictieve warde en instrumentele utiliteit van de desbetreffende psychometrische onderzoeksgegevens woor de psychologische arbeidsongeschiktheidsdiagnostiek.

Ondat er geen eenduidig en extern objectief criterium bestat voor arbeidsgeschiktheid versus arbeidsongeschiktheid, en de oordeelsvorming daaromtrent grotendeels berust op cansensus wan de oordelende advies-, uitwoerings- en beroepsinstanties, eventueel na inwinning van een extern deskundig advies, wordt het predictieve vermogen, dat aan de onderzoeksbevindingen mag worden ontleend, empirisch getoetst aan de hand van de volgende criteria:

- de mate warin de psychometrische onderzoeksgegevens een significant onderscheid maken «ussen mensen die door de psycholoog-adviseur als arbeidsgeschikt, respectievelijk arbeidsongeschikt zijn geclassificeerd;

- de mate watrin de psychologische arbeids(on)geschiktheidsadviezen door de opdrachtgevende instanties zijn overgenomen;

- de mate warin betrokkenen wel en niet in beroep zijn gegaan tegen cen mede op het psychologisch advias gebaseerde 'voor beroep vatbare beslissing" van de uitvoeringsorganen;

- de mate warin in geval van beroepszaken de beroepen tegen de 'voor beroep vatbare beslissingen" door de beroepsinstanties (on)gegrond zijn verklaard.

Woonoemde criceria representeren in deze studie het zogenaande "predictie- 
doel" (De Gropt, 1972). han de hand van de hiervolgend beschrevan vragstelingen zal de predictieve warde van een antal psychometriache onderzoeksgegevens ten anzien van de desbetreffende crietia met behulp van uni- en multivariate technieken nader worden geanalyeded. op gtond daarvar kan dan de instrumentele ut i liteit van de desbetreftende psychometrische instrumenten worden bepald en kumen (voorlopige) bes lissings regels woor de psychologische arbeidslongeschiktheidsdiagnost id worden ge formuleerd.

\subsection{WRAASTELLINGEN}

Refererend aan de globale probleenstelling kunen de volgende vragstelingen worden geformuleerd, welke als zodanig het uitgangspunt voor deme studie vormen:

1. In welke psychologische persoonskenmerken verschillen personen die door de psycholoog-adwiseur als respectievelijk arbejdsgeschikt en arbeidsongeschike worden geclassificeerd?

2. Wat is de predictieve waarde van de psychometrische onderadegegevens, alzonderlijk en in combinatie, ten aazien van:

- de beslissingen van de psycholoog-adviseur (advies arbeidsgaschikt/arbeidsongesctrikt);

- de beslissingen van de opdrachtgevers (advies wel/niet overgenomen);

- de beslissingen van de betrokkenen (wel/niet in beroep gegam);

- de beslissingen van de oordelende beroepinstanties (beroep we $1 / n i a t$ gegrond verk a a r d ) ?

3. Welke beslissingsregels kunnen op grond van de geconstaterede predintheve warde van de desbetrefiende psychometrische onderasobgegevens voor de psychologische arbeidsongeschiktheidsdianogtiek wordeg geformulerd?

4. Welke psychometrische onderzoeksinstrumenten komen op basis van hum 
instrmentele uriliteic in anmerking voor toekonstig gebruik bij de prychologische arbeids(on)geschiktheidsdiagnostiek?

Teneinde voonoemde vraagtellingen te beanwoorden heeft er een retrospectief onderzoek platsgevonden. Als zodanig zijn eerder verworven onderzoeksbewindingen geanalyseerd, hetgeen enerzijs richting en anderzijds beperkingen heeft gegeven aan het onderzoek.

Deze studie is een beschrijuing van een op een psychologische praktijk gebaseerd onderzoek met een descriptief, exploratief en mogelijk prescriptief karakter, wasvan de resultaten niet zonder meer in tijd, plats en personen te generaliseren $z i j n$.

Het onderzoek is descriptief voor zover het gat over de beschrijuing van de toegepaste pisychometrische onderzoeksinstrumenten en de daarmee verworven gegevens, het gehanceerde beslissingsmodel, de verstrekte arbeids(on) geschiktheidsadviezen en de consequenties daarvan voor de beslissingen van respectievelijk de opdrachtgevers, betrokkenen en beroepsinstanties.

Het onderzoek is exploratief war het gat om door middel van statistische analyses te ontdekken in welke mate de psychologische arbeids(on)geschiktheidsclassificaties van de psycholoog-adviseur berusten op objectiveerbare psychometrische onderzoeksbevindingen, c.q. de verschillen tussen arbeidsgeschikten en arbeidsongeschikten statistisch kunnen worden verklaard en voorspeld.

Het onderzoek kan prescriptief zijn voor zover de onderzoeksbevindingen conclusies toelaten omtrent het predictieve vermogen en de instrumentele utiliteit van de psychometrische onderzoeksgegevens ten aanzien van het classificeren van de categorie arbeidsgeschikten versus arbeidsongeschikten. Op grond daarvan kunnen (voorlopige) beslissingsregels worden geformleerd en aanbevelingen worden gedaan woor toekomstig gebruik van bepalde psychometrische onderzoeksinstrumenten bij de psychologische arbeids(on)geschiktheidsdiagnostiek. 


\section{ARBE IDSONGE SCHIKTHETD}

\section{PSYCHOLOGISCHE ARBEIDS(ON)GESCHIKTHETDSDIAGNOSTTER VANUTT HISTORISCH PERSPECTIEF}

Reeds ten tijde van het Romeinse Rijk van 200 voor tot 200 na Christus werden mensen beoordeeld op hun "arbeids 60 geschiktheid'. Dit betrof overigens alleen burgers die wrijwillig in militaire dienst waren gegan en zo gehavend wit het strijdgewoel te voorschijn waren gekomen, dat zij hun militaire functie niet meer nar behoren konden vervullen en hun oorspronkelijke werk niet meer konden doen. Soms werd daar een uitkering van 'rijkswege' tegenover gesteld in de vorm van een passende aantekkelijke functie of een stuk land, zodat men in de gelegenheid was on ongeveer op gelijke woet verder te leven. De revalideerbaren onder hen ontwingen nazorg in zogenaande "valitudinaria' om vervolgens weer terug te kunnen keren in de strijd (Bremer, 1972).

In de loop der eeuwen werd de aawezigheid van lichamelijk en geestelijk gebrekkigen die nawelijks of niet werkten in wisselende nate als een mat schappelijk gegeven aanvaard. Tn het voor-industriële tijdperk konden echter de meesten van hen, ondanks beperkte capaciteiten en mogelijkheden, toch een zekere bijdrage leveren an de coen nog voornamelijk agrarische arbeid en huisnijverheid.

Wet het coenemende beroep op arbeidspotentieel door de industriële ontwikkelingen en het ontstaan van de fabrieksarbeid kwam de categorie 'onvolwardigen' ofwel. "arbeidsongeschikten' steeds meer onder de aandacht.

Zoals in de Romeinse tijd soldaten na opgelopen verwondingen in valicudinaria weer militair inzetbaar werden gemakt, zo werd vanaf het begin van het industriele tijdperk het herstel van de arbeids-inzetbarheid van zieken, gebrekkigen en uitgevallen werknemers nagestreefd.

Onder inwloed van enerzijds de coenemende werkdruk, de mechanisatie, de specialisatic en de economische expansie en anderzijds de ontwikling van het stelsel van sociale voorzieningen rakten steeds meer mensen met ziekten en gebreken buiten het arbeidsproces. Over deze groep arbeidsongegchikten ging men zich steeds meer zorgen naken: 'eerst als maatschappelijhe 
anotialie en vervolgens als object var medisch handelen (Dechesne en Buijog, 1983).

De problematiek van het 'gehandicapt 2 ijn' werd gedefinieerd in termen van economische inproduktiviteit ex financiele onzelfscandigheid. Het medisch handelen werd mede daardoor twenemend gericht op herstel van de arbeidsgeschiktheid van gehandicapte mensen, teneinde hen zodoende weer gereed te maken om aan het produktieproces te kunnen deelnemen.

Voor zover gehandicapte mensen ook werden beschouwd als "een categorie die in onze samenleving veel kastende financiele rechten heeft, weinig matschappelijke verplichtingen kent en steeds minder verantwoordelijkheid voor de eigen gezondheid op zich neemt" (Boelen en Bremer, 1987), ontstonden matschappelijke regelingen on hen te beoordelen op hun dadwerkelijke onvermogen om te kunnen werken.

Typerend voor de situatie in dezen op het einde wan de lgde eeuw is de rede die de chirurg Renssen hield over: 'De verzorging der gebrekkigen en mismakken" " met daarin de uhtspraak: "Wij zien woor ons geestesoog een grote groep kleine kinderen die, groter wordende, nooit in staat zullen zijn doon eigen arbeid in hun onderhoud te voorzien, die te beschowen zijn als parasieten, die de rijke bron vormen waruit de bedelars, de bezienswardigen en de gebrekkige merkwardigheden voortkomen. Een rekensom makt duidelijk dat het voor ons national vermogen een aarwinst is, wanneer deze paria"s tot arbeid kunnen worden gebracht" (Renssen, 1899). Aanvankelijk richte men zich op de gehandicapte kinderea, "ondat daraan nog lets viel te doen", aldus Biesalski (1911).

Ten aanzien van volwassenen werden witlatingen gedaan, die ook thans nog in discussies over de sociale voorzieningen meek 1 inken: "zij genieten een witkering en zijn op grond daarvan niet gemotiveerd on weer aan het werk te gaan." (Büesallski, 19|1).

Onder de druk van de matschappelijke en economische ontwikkelingen breidde in de loop der tijd de andache zich uit tot het revalideren van de volwassenen, met als doel het bevorderen van het arbeidsvermogen. In zijn historisch-psychologische beschouwing over het ziekenhuis wijst Bremer (1972) erop, dat in het begin van deze eeuw het ziekenhuis nog onweersproken kon worden gedefinieerd als "een social-meconomische instelling met 
het doel het produktievermogen van het volk te herstellen en te vergroten" (Wortman, 1915).

In het Nederlands Tijdschrift voor Geneeskunde van 1923 stelde Biesalski: "dat de aalmoesontvangende bedelar in een belastingbetalende burger moest worden omgezer, waarbij de zieken en gebrekkigen onder hen zodanig moesten worden verpleegd, behandeld en gerevalideerd, dat zij uiteindelijk weer geschikt zouden worden voor arbeid."

In het verlengde van de industriele revolutie was het derhalve in het begin van deze eeuw met name de "arbeidsongeschiktheid" wan zieken en gebrekkigen, die hen tat object van medische zorg makte.

Gaandeweg gingen revalidatie-instellingen hun werkijzen en doelstellingen formuleren in termen van een untegrale, medisch-educatieve aanpak, gericht op behandeling, opwoeding, onderwijs en beroepsworming.

Men is de te revalideren populatie als een social-geneeskundig probleem gaan zien, toen bleek dat er, ondanks deze zorg, nog heel wat mensen met een handicap overbleven, die niet aan het rbeidsproces konden deelnemen. Bovendien vielen veel mensen, na enigherstel, opnieuw uit en moesten daarom beoordeeld worden op hun uitkeringsrechten krachtens de coen geldende ongevallenwet $(1901 / 1921)$.

In 1921 kreeg de Rijksverzekeringsbank - coen belast met de uitvoering van bepalde sociale verzekeringswetcen - de bevoegdheid en de mogelijkheid tot het regelen en financieren van omscholing en revalidatie. Deze bevoegd heid wormde de grondslag van de verzekeringsgeneeskunde; in 1963 officieel erkend alls de vilerde specialisatie binnen de sociale geneeskunde, naast de arbeids- en bedrijfsgeneeskunde, jeugdgezondheidszorg en algemene gezondheidszorg. Bovendien vormde genoende bevoegdheid tegelijkertijd uen belangrijke voorwarde voor de ontwikkeling van de psychotechniek en later de pychodiagnostiek in dit specifieke werkveld.

De psychologie werd coen in eerste instantie vooral gewardeerd wegens zijn psychotechnische onderzoksmogelijkheden. Selectie en beroepskeuze vormden destijds de hoofdmoot van de psychologische adviespraktijk. In deze periode zijn de eerste psychologische adviesbureaus opgericht (Roe, 1982), die o.a. werkten in opdracht van de Rijksverzekeringsbank. Dit is niet verwonderlijk gezien de doelstelling van de Rijksverzekeringsbank: beoordeling van hernieuwde geschiktheid woor arbeid en het treffen 


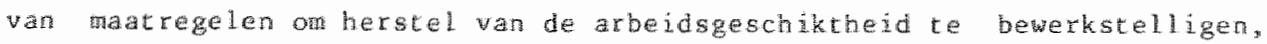
eventueel met gebruknaking wan de herscholingsmoge ijkheden uit ae ongevallenest vart $1901 / 1921$.

Wede omdat, ondanks revalidate en scholing, reuntegratie in het arbeids proces dikwijls mislukte, mamer de geschillen tussert de Rijksverzekeringsbank en verekerden omtrent het wel of niet arbeidsgeschikt zijn toe Als gevolg darvan who op grond van de Beroepsutet van 1902 in het kader van de sociale verekeringsrechtsprak toenemend een berop gedan op forengische pychiaters. Het was an hen om vast te stellen in hoeverre er grake was wan een arbeidsbelemmerend psychiatrisch ziektebeeld or gebrek.

Herrema (1959), psychologg en ambenar bij de tommalige Rijksverzekeringsbank, concludeerde in zijn disertatie bat cot in deze periode zowel het bijbrengen van beroepswardigheden, als het weer arbeidsgeschikt verklaren wegens a fwezigheid wh een psychiatrisch ziektebeeld betrekkelijk weinig resultat opleverden ten a zaen van de daadwerkelijhe terugkeer in het arbe idsproces.

Volgens Herrema (1959) werd er te weinig rekening gehouden met een eventueel zwake motivatie tot het verrichten van arbeid als gevolg van de belewing van de handicap door betrokkene en diens orggeving. De psychische verwerking van de handicap en de eigen subjectieve perceptie van het resterende abeidsvermogen kregen meer a andacht nargelang steeds duidelijker werd dat niet zozeer ernstge psychiatische ziektebeelden, maar woral deze psychologische fenomenen de struikelblokken waren wardoor terugplagtsing in het arbeidsproces nogal eens mislukte. ondanks een psychit ische abbidsgeschiktheidsverklaring konden veel mensen door een invalidarende handicapverwerking en onvoldoende aampassingsvermogen toch

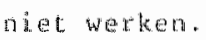

Revalidacie en abeidsresnegratie werden onder meer op grond van deze dnzichten steeds meer als een pychollogische angelegenheid gezien. Psyanische en psychomsociale factoren werden in de loop der tija toenemend als bevorderende en ondethoudande oarzaken wan ziekreverzuim en arbeidsongenchiktheid onderkend en erkend (wight, 1960). Deze ontwikkeling werkte mede een interdisciplinaire samemerking tussen de medische en psychologische disciplines in de hand (Lancée, 1980). Daarmee kregen de 
psychologen de mogelijkheid om zich binnen het specifieke werkueld van de revalidatiegeneeskunde en verzekeringsgeneskunde verder te profileren.

Gezien de mate warin voornoemde wisie op arbeidsongeschiktheid en woorkoming daarvan thans ingang heeft gevonden, is het begrijpelijk dat door verzekeringsgeneeskundigen steeds meer een beroep wordt gedaan op psychologen.

Sinds de inwerkingtreding van de WAO (1967) is het Revalidatie-Instituut Muiderpoort (RIM) één wan de eerste revalidatiecentra geweest met een eigen psychologische afdeling, die zich op geintegreerde wijze, in samenspraak en samenwerking met de Gemeenschappelijke Medische Dienst (GMD), met psychologische arbeids(on)geschiktheidsdiagnostiek is gaan bezighouden (liak, 1970).

Inmiddels is een dergelijke vorm van samenwerking tussen revalidatiecentra en de GMD landelijk gebruikelijk, al geldt in het algemeen dat daarvoor (nog) geen wet- en regelgeving bestaat (Epker, 1987). Daarnaast zijn er ook gereguleerde vormen van samenwerking tussen de GMD en revalidatie-afdelingen van algemene ziekenhuizen ontstaan.

Vos (1976) beschrijft hoe er op initiatief van de GMD een aantal samenwerkingsprojecten tussen de GMD en de revalidatie-afdelingen van algenene ziekenhuizen zijn opgezet. Deze samenwerkingsprojecten hebben onder meer geleid tot platselijk en regional gestructureerd overleg tussen de verzekeringsgeneeskundige en de curatieve sector. Het doel van deze gestructureerde samenwerkingsprojecten is het arbeidsreintegratieproces van nog in het ziekenhuis opgenomen patienten te bevorderen door het vroegtijdig signaleren van diegenen, die gezien de ard van hun aandoening(en) in de WAO dreigen te komen. Naast een somatisch onderzoek kan er bij de betrokken patiënten psychologisch onderzoek platsvinden, dat is geticht op het bepalen van verdere behandelmogelijkheden en toekomstige passende beroepsmogeli jkheden (Lancée, 1979).

Deze ontwikkeling van een geintegreerde vorn van samenwerking tussen de sociale verzekerings- en curatieve sector, heeft mede het inzicht bevordert dat psychologisch onderzoek een relevante bijdrage kan leveren ten aanzien van het beoordelen van arbeids(on)geschiktheid (Lancée, $1981 c$ ).

Daarmee is binnen het werkveld van de "Psychologie van Mrbeid en Gezondheid" (Schabracq, 1988) de basis gelegd voor de 'sociale verzekeringspsy- 
chologie" die zich in het bijzonder bezighoudt wet de psychologische arbeidg(on)geschikcheidsdiagnostiek, uitgevoerd binnen het kader van de arbeideongeschitheidswergeving.

\subsection{DE ARBEIDSOHGESCHIKTHETDSWETTEN}

De arbeidsongeschiktheidshetten hebben waraf het begin wan deze eeuw een snelle ontwikeling doorgemakk. Binnen de context van deze studie zou het te ver gan on het ontstan en de ontwikkeling van de arbeidsongeschiktheidswetten uitgebreid the beschrijwen.

"Toch is enige kennis nodig van de denkbeelden die meer dan driekwart eeuw geleden hebben geleid tot het ontstan van de arbeidsongeschikcheidswetgeving on de huidige arbeidsongeschiktheidswetten te kunnen platusen", aldus Veldkamp in 1976.

op grond daarvan wordt hier kort de geschiedenis van de desbetreffende arbeidsongeschiktheidswetten vermeld (2.2.1) en vervolgens zullen de huidige arbeidsongeschiktheidswetten en recente wijzigingen daarin worden beschreven $(2,2,2)$.

\subsubsection{Geschiedenis van de arbeidsongeschiktheidswetten}

Vanut historisch-matschappelijk perspectief vertoont de gezondheidszorg een ontwikkeling die qua vraag verloopt van een gurst naar een recht en gua invloed van particulier intiatief nar de overheid. Parallel daamee loopt de ontwikkeling van de sociale voorzieningen van een 'sociale verzekering" natr een "sociale zekerheid" (Weldkanp, 1976).

Het stelsel van de sociale verzekeringswetgeving nam in Nederland daadwerkelijk een anvang met de Ongevallenwet in 1901. Het was de eerste wet die het karakter kreeg van een verplichte sociale verzekering, welke werd verzorgd door de Rijksverzekeringsbank (later Sociale Verzekeringsbank). Deze wet beperkte zich in het begin tot het financieren van de geldelijke gevolgen wan bedrijfsongevallen van een beperkte groep werknemers * namelijk degenen die in de meest gevaarlijke industrieën werkzaam waren. Met deze 
wetgeving inzake sociale zekerheid werd gekozen woor een verzekeringsconstructie op basis van strikte causaliteitsbetrekkingen. Dit impliceerde een relatie tussen de te betalen premie en het risico dat er werd gelopen van een bedrijfsongeval enerzijds en de arbeidsprestaties die werden geleverd en de hoogte wan de eventueel te verlenen periodieke uitkering anderzijds.

Beroepsziekten (bijvoorbeeld bakkerseczeem) en ongevallen, opgeloper in de vrije tijd wielen niet onder deze ongevallenwet (1901).

Pas in 1921 werden de werknemers van alle industriele bedrijven onder de ongevallenwet gebracht.

Na de Ongevallenwet van $1901 \mathrm{kwan}$ in 1919 de Invaliditeitswet (Tw), die voorzag in een uitkering woor loontrekkende werknemers bij blijwende invaliditeit als gevolg van verlies wan temminste $2 / 3$ deel (ongeveer 66\%) van de verdiencapaciteit.

Invaliditeit omate niet alleen lichamelijke ziekten of gebreken, maar ook psychische ziekten en stoormissen, gezien de toenmalige definitic: "Hij die door ziekten of gebreken buiten stat is om met arbeid, die voor zijn kracht en bekwambeid is berekend en met het oog op zijn opleiding en vroegere beroep hem in billijkheid kan worden opgedragen, ter plaase war hij arbeid verricht of het latst verricht heeft, of op een naburige soortgelijke plaats, $1 / 3$ te verdienen van hetgeen lichamelijk en geestelijk gezonde personen van dezelfde soort en van soortgelijke opleiding op een zodanige plaats met arbeid gewoonlijk verdienen".

Deze Invaliditeitswet, waran de nam van minister Talma onverbrekelijk verbonden is, was de eerte wetclijke regeling ten behoeve van een meer veralgemeende sociale zorg. Nast de Beroepswet van 1902 , warin de wi.ju van procederen bij geschillen ontrent de toepassing van de sociale verzekeringswetten was geregeld, wormde de Invaliditeitswet een bellangrijke woorwarde voor onder meer de latere ontwikkeling van de niet-strafrechtelijke forensische psychiatrie en psychologie. Gezien de formulering ging het in genoemde. Invaliditeitswet niet on de lichamelijke gesteldheid of de psychische toestand op zich, maar on de mate warin door onvoorziene en orvoorspelbare veranderingen daain als gevolg van een ziekte of gebrek daadwerkelijk eer beduidende en blijvende vermindering in de verdiencapaci- 
teit kon worden aangetoond. In deze wet waren al een arat ultgangspunten anwezig wan de huidige arbeidsongeschikheidsweten.

Drie jar na de Inwaliditeitswet werd per 1 juli 1922 de pensioenwet in werking gesteld, warwan de uitvoering werd opgedragen aan de zogenaamde "Bensioenraad" - het Latere Algemeen Burgerlijk Pensioenfonds (ABP). Met deze wet verkregen invalide ambtenaren het recht op pensioen, al moest het wel overduidelijk zijn dat ze niet in staat waren uit de eigen middelen in het levensonderhoud te voorzien, wilden zij dat pensioen ook daadwerkelijk krijgen (statsuitgeverij, 1949).

In 1928 werden de bedrijfsgeneeskundige diensten door de overheid erkend en kreeg de bedrijfsgeneeskunde in het kader van de ongevallenwet een wettelijke basis, met de Arbeidsinspectie als controle- en beroepsinstantie. Tegelijkertijd wond toen een gelijkstelling plats van beroepsiekte met bedrijesongevall.

In 1930 trad de Ziektewet in werking voor werknemers in loondienst beneden een bepalde loongrensi.

Zwangerschap werd gelijkgesteld an ziekte, maar dit gold alleen voor gehuwde vrouwen; na de Tweede wereldoorlog konden ook ongehuwde vrouwen in dezen anspraken doen gelden. In geval van ziekte werd men na zes maanden beoordeeld volgens de normen van de Invaliditeitswet.

Het ontwerp van de Ziektewet (zw) kende oorspronkelijk twee doellen: een verzeker jng tegen loonderving wegens ziekte en een verzekering tegen ziektekosten "In de ziektewet van 1930 werd witeindelijk echter alleen de verzekering tegen loonderving wegens ziekte geregeld.

De ziektekostenverzekering is later apart geregeld in het ziekenfondsbesluit van 194: en vervolgens in de ziekenfondswet (1964) en in de Algemene Wet Bijzondere Ziektekosten (1967).

In 1947 werd de 2 iektewet-periode verlengd tot éển jaar, ondat de uitkering van de Tnvaliditeitswet te lag werd bewonden.

In 1963 kwan nast de Invaliditeitswet de Interimwet-Invaliditeitsrentetrekkess (IWI) tot stand, die de mogelijkheid bood de uitkering van degenen die na de ziektewet krachtens de I een te lage witkering ont- 
vingen, an te vullen tot een anvaatbar te achen nivean (van der pas, 1978).

Grondslag voor de IW en de IWI vormde de arbeidsongeschiktheid op grond van ziekte of gebrek. De wetgever ging er - achterat ten onrechte - van uit dat onder medici voldoende overeensteming bestond over wat ziekte en gebrek was, zodat vrij nawken per lichaatsdeel de arbeidsbeperkingen en darmee de mate van arbeidsongeschiktheid zouden kunmen worden vastgesteld. Pas later bleek in de praktijk dat het op deze wijze vastallet van de mate van arbeidsongeschiktheid in de meeste gewallen niet was te handhaven. Dit is nog eens versterkt door de dacrop wolgende wettelijke omschrijuingen van arbeidsongeschiktheid. Darin kregen, nast een sociaal-medisch aspect, ook een arbeidskundig en loontechnisch aspect een essentiele rol in de wijze warop de mate van arbeids(on)geschikthe moesc worden bepaald.

Na de Tweede Wereldoorlog zijn de actueel geldende Allgemene Burgerlijke Pensioenwet (1966), de gewijzigde Ziektewet (1967), de wet op de Arbeidsongeschiktheidsverzekering (1967) en de Algemene Arbeidsongeschiktheidswet (1976) van kracht geworden.

Deze wetten regelen onder meer de huidige verplicht gestelde arbeidsongeschiktheidsverzekering en bepalen de uitkeringspercentages ingeval er, alls gevolg van ziekte of gebrek, sprake is van onvermogen on te werken, c.q. loon te verdienen. Doel ervan is het doen voortbestaan van de eigen mogelijkheden en de eigen leefwijze van het individu, weergegeven in twee rechtsgronden:

- het recht op zelfontplooiing en

- het recht op gelijke kansen.

Met deze wetten is het principe van 'ruilevenwicht' cussen risico, premie en witkering volledig losgelaten ten gunste van het principe der 'matschappelijke solidariteit". Daarmee is de groep verzekerden witgebreid van de matschappelijk zwakkeren tot de gehele groep der loontrekkenden en zelfstandigen, warbij de grondslag van de verzekering niet meer het 'risque professionel', maar het 'risque social' geworden is (Veldkamp, $1976)$.

Het gaat niet meer om hóe men arbeidsomgeschikt is geworden, maar dàt men arbeidsongeschikt is. Dit geldt voor alle huidige arbeidsongeschiktheids- 
wetcem warmee psychologen die zich bezighouden met arbeidscon)geschiktheidediagnostek ce maken kuner hebben.

\subsubsection{Huidige arbeidsongesch iktheidswet ten}

De huidige arbeidsongeschiktheidswetgeving heeft mede toc doel de volks gezondheid vanuit een wetelijk-juridisch kader te steuren (Muntendam, 1977). De verplichte arbeidsongeschiktheidsverzekering is thans geregeld un de Algemene Burgerlijke Pensioenwet (ABP-wet) van 1966 , de gewijzigde ziektewer (2W) van 1967, de Wet op de Arbeidsongeschiktheidsverzekering (WAO) van 1967 en de Algemene Arbeidsongeschiktheidswet (AAW) wan 1976. voor respectevelijk de ambtenaren, werknemers en de gehele bevolking.

\section{Algemene Burgerlijke Pensioenwet (ABP-wet)}

Historisch heett de Algemene Burgerlijke Pensioenwet zich geheel los ontwikkeld van hetgeen men de sociale zekerheidswetgeving pleegt te noemen. llang vóór de moderne sociale zekerheidswetgeving in het particuliere bedriffsleven in ons land tot bloei kwam, was pensionering van ambtenarem door middel van onderlinge verzekeringsfondsen als extra beloning en privilege een bekend verschijnsel. De pensioenlasten kwamen geheel ten laste van de schatkist (prenievij pensioen).

In de loop der tijd kwanen er, mede onder invloed van andere opvattingen over de taak van de gemeenschap en de overheid tegenover het individu, vele vetanderingen in de pensioenwergeving, wardoor deze steeds moeilijker te hanteren werd.

De Algemene Burgerlijke Pensioenwet van 1966 wis bedoeld als vereemoudiging van de pensioenwet van 1922 en moest aansluiten op de matschappelijke ontwikkelingen van die cijd, aldus de opdracht an statscomissie Van Prol je $(1949)$.

Het penstoenfonds - toen nog onder de natan "Pensioenraad" in Den Hag gewestigd - werd gelijktijdig omgedoopt tot het 'Algeneen Burgerlijk Penshoenfonds" en kreeg als zodanig de uitvoering van deze wet opgedragen. De opdracht houd in het utvoeren van de ambcelijke pensioenvoorziening en daruit voortwloeiend het beheer van het fondsuermogen. 
Het begrip "pensioen" is intiddels uitgegroeid tot een veramelnam voor een groot aantal sociale worzieningen ten behoeve van dat deel van de bevolking dat qua pensioenwerzekering ressorteert onder de ABPwet. De ABp-wet betreft een wettelijke collectieve voorziening die ervoor zorgt dat een eenmal door ambtenaren en semi-ambtenaren opgebout welvartsperil tot op zekere hoogte gehandhaafd kan blijven (ABP, 1981).

ondanks dat de ABP-wet in beginsel niet op de sociale vertekeringsgedachte is gestoeld, komen de actuele verzekeringstechnische, sociaal-economische en medische aspecten in vergaande mate met die van de sociale zekerheidswetgeving owereen (Mannoury en Asscher-Vonk, 1987).

Volgens de ABP-wet krijgt betrokkene alleen een invalidiceitspensioen (IP), indien hij of zij blijvend arbeidsongeschikt wordt beschouwd voor het eigen werk op grond van ziekte of gebrek.

Bij de vaststelling van de hoogte van het invaliditeitspensioen spelen diensttijd en invaliditeitspercentage een rol. Een eventuele gedeeltulijke werkloosheid wordt niet verdisconteend. Bovendien stelt de ABP-wet expliciet dat de ongeschiktheid in overwegende mate moet berusten op somatische en/of psychische functiestoornissen alls gevolg van en/of samenhangend met ziekte of gebrek.

Voor het vaststellen van de mate van algemene invaliditeit wordt verwezen nar paragraaf 2.3 .

\section{Ziektewet $(Z W)$}

De ziektewet verzekert werknemers tot 65 jaar tegen loonderving wegens ziekte, ongeval en gebreken en geet recht op een uitkering gedurende ten hoogste 52 weken.

Er is sprake van arbeidsongeschiktheid in de zin var de ziektewet. indien betrokkene op grond van ziekte of gebrek ongeschikt is voor zijn eigen laatst verrichte werk bij zijn eigen werkgever (zW, antikel $\| 9$ ).

De Ziektewet kent geen klassen wan arbeidsongeschiktheid.

\section{Algemene Arbeidsongeschiktheidswet (AAW)}

De AAW verzekert alle ingezetenen in Nederland die de leeftijd wan 65 jaar nog niet hebben bereikt tegen de geldelijke gevolgen van langdurige arbeidsongeschiktheid wegens ziekte en gebrek. Recht op uitkering heeft de 
verzekerde die voor $25 \%$ or meer arbeidsongeschikt is, nadat de ongeschintheid 52 weken heet gedurd.

Aar verzekerden die de leeftijd van 18 jaar nog niet hebben bereikt, wordt gext uitkering toegekend. 'Jeugd-gehandicapten' hebben in principe recht op een MA-uikering vanaf hun 18 de jat, waneer ze vanaf hun 17 de jaar of darvoor onafgebroken arbeidsongeschikt zijn geweest.

Sinds 1976 valt de in loondienst werkende beroepsbewolking niet meer prämair onder de Who, maar onder de AAw. Aam werknemers wordt een supplet he vinuit de WAO toegekend, voorzover het uitkeringsbedrag de AAW-uitkering overteft.

Per I januari 1980 is de AAW gewijzigd om mannen en wrowen in het sociale verzekeringsstelsel geljjke behandeling te geven. Ook een getrouwde vrouw heeft recht op een AAW-uitkering, mits ze aan bepaalde vootwaarden voldoet.

In de exste plats moet betrokkene woldoen an de zogenaande "referce"of inkomenseis, dat wil zeggen dat in het jaar voorafgaand an het intreden van de arbeidsongeschiktheid een bepaald inkomen mot zijn verworven wit of in verband met arbeid in het bedrijfs- en beroepsieven. De hoogte van de ütkering wordt bepald door:

le. de algemene grondslag (= wettelijk minimumLoon);

2e. de individuele grondslag.

De individuele grondslag wordt berekend op basis van de gemiddelde verdiensten van vóór de arbeidsongeschiktheid (eigen dagloon). De individuele grondslag wordt overigens alleen toegepast in die gevallen warin de inkomsten minder bedragen dan het volle wettelijke minimumloon.

De AAW opent, zoals tot 1976 de WAO, de mogelijkheid in bepaalde gevallen voortieningen in de leetsfeer en/of tot behoud, herstel of bevordering wan de arbeidsgeschiktheid te treffen. "len anzien van het recht op deze voorzieningen geldt geen wachteijd.

Personen beneden de 18 jaar en andere verzekerden die geen recht hebben op een uitkering, kumnen wel woor voorzieningen in aanmerking komen.

In principe bestat ook in dit verband de mogelijkheid dat er een psychologische beoordeling wordt gevragd, alvorens tot verstrekking van voorzieningen wordt overgegan. 


\section{Wet op de Arbeidsongeschiktheidsverzekering (WAO)}

De wo verzekert werkmemers tot aan 65 jaar tegen loonderving wegens ziekce, ongeval en gebreken na de ziektewetperiode, dat wil zeggen na een arbeidsongeschiktheidsdur van 52 weken. Het criterium voor arbeidsongeschiktheid is bij de WAO, anders dan bij de ZW, gehele of gedeelcelijke ongeschiktheid voor werk in het algemeen.

Het begrip arbeidsongeschiktheid ofwel het onvermogen tot het kunden verrichten van betald werk is bepald niet identiek aan somatische en/of psychische invaliditeit.

Erkenning van medische, dat wil zeggen somatische en psychische oorzaken voor arbeidsongeschiktheid, maar ook andere, niet-medische redenen wordt mogelijk gemakt door de wettelijke omschrijuing ervan in respectievelijk artikel 18 eerste lid wan de WAO, artikel 5 eerste lid van de RA an artikel Fo tweede lid wan de ABP-wet:

"Arbeidsongeschikt, geheel of gedeeltelijk, is hij die ten gevolge van ziekten of gebreken geheel of gedeeltelijk buiten stat is om met arbeid, die voor zijn krachten en bekwamheid is berekend en die met het oop op aijn opleiding en wroeger beroep hem in billijkheid kan worden opgedragen. cer plaatse war hij arbeid verricht of het latst heeft verricht of op een naburige soortgelijke plaats, te verdienen, hetgeen lichamelijk en geestelijk personen van dezelfde soort en soortgelijke opleiding op zodanige plats met arbeid gewoonlijk verdienen.

De criteria opleiding, beroep, regio (afstand), latst verdiende Loon en situatie op de locale arbeidsmarkt, zijn nast de constatering van een ziekte of gebrek, tot eind 1986 mede van belang geweest bij de bepalling of i.emand wel of niet als arbeidsongeschikt kon worden beschouwd.

Pij de stelselherziening van I januari 1987 heeft ar 0 . a. een herformulering van het arbeidsongeschiktheidscriterium platsgevonden. Iermand die wookheen op grond van zijn of hat resterend arbeidsuernogen ten dele arbeidsgeschikt was, mar als gevolg van de handicap weinig of geen kang had on op de vrije arbeidsmarkt geaccepteerd te worden, kreeg tot l januari 1987 coch een volledige arbeidsongeschiktheidsuitkering. Daarmee werd het gedeelte warvoor men eigenlijk als werkloos werd beschouwd "verdisconteerd" in de uiceindelijke arbeidsongeschiktheidsclassificatie (Haak, 1970). Met deze wetswijziging zal iemand alleen nog over dat 
percentage een AhW/Wh-uitkering krijgen, waarvoor hij als gevolg wan een ziekte of gebrek als arbeidsongeschikt worde beschow

Gedeeltelijk arbeidsongeschkte werknemers krijgen nast hun womitkering, ongeacht hum leeftijd en werkloos-zijn of worden, een uitkering voor het gedeelte dat zij in principe arbeidsongeschikt zijn volgens de nieuwe wet op de Inkomensvoorziening voor Oudere en gedeeltelijk Arbeidsongeschike werkloze werknemers (roAw). Deze toAm heeft ten doel de positie van de daarin genoemde werknemers te handhaven door hen inet afhankelijk te lacen worden wan een bijstandsuitkering.

Een zelfde regeling is er sinds I juli 1987 voor oudere en gedeeltelijk arbeidsongeschikte zel. Estandigen ( $10 \mathrm{Az}$ ).

Behalve dat de verdisconteringsbepalingen van de werkloosheid zijn vervallen, is tevens het 'ter plaacse war"-criceriur uit de wetcelijke definitie van arbeidsongeschikcheid geelimineerd. Thans gelden de landelijk voorkomende beroepen en vacatures als uitgangspunt vool het bepalen van 'dujdbare functies'.

Verder worden vanaf 1 januari 1987 alle AAW/WAO-uitkeringsgerechtigden wan 35 jaar en jonger herbeoordeeld wat betreft hun mate van arbeidsongeschiktheid.

op basis warvan en hoe in de dagelijkse praktijk van de advies- en uitvoeringsorganen thans de arbeids(onjgeschiktheidsbeoordeling tot stand komt, wordt in de volgende paragraaf (2.3) besproken.

Voor een overzicht van de hiervoor beschreven arbeidsongeschiktheidswetten, de desbetreffende advies- en uitvoeringsorganen en hun platsbepaling binnen de context van onze huidige sociale verzekeringswetgeving wordt verwezen nat schema 2 .

Terwille van de overzichtelijkheid is het Algemeen Burgerlijk Pensioenfonds als uitwoeringsorgan woor het overheidspersoneel, evenals de relatie tussen de sociale verzekeringswetten en de pensioenvoorzieningen volgens de ABP-wet, weggelaten. Daarvoor wordt verwezen nar 'Pensiloen en pensioentonds' (ABP, 1981 ). 
Schema 2: Overzicht huidige sociale verzekeringswetgening en aduido- an uithoringsorganem

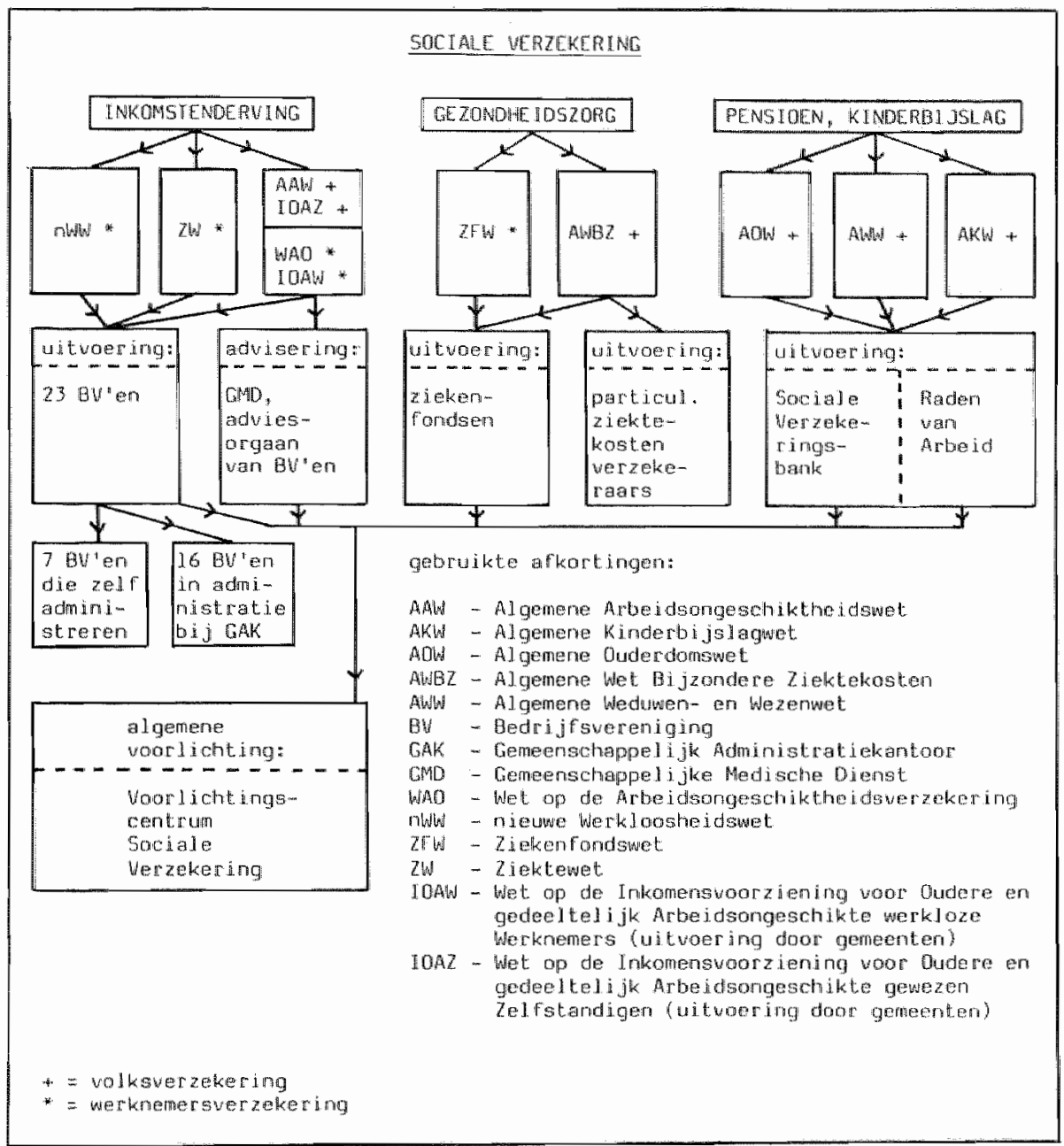

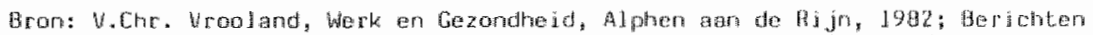

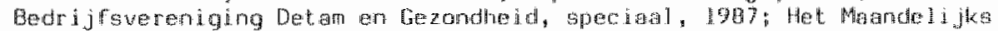

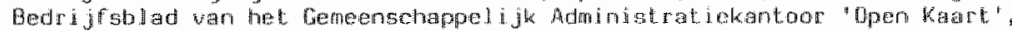
jeargang $31, \mathrm{n} \cdot \mathrm{r}, 3,1988$.

\subsection{ALGEMENE PRARTIJKGANG BIJ DE ADVIES- EN UTTVOERINGSORGANEN VAN DE AREETDSONGE SCHIKTHEIDSWETTEN}

De beslissingen over de mate van arbeidsongeschiktheid in het kader van de 
AAH/WO worden genomen door de bedrifeverenigingen (BV'en), die daarontrent worden geadviseerd door de Gemeenschapelijke Medische Dienst (GD). Er zijn 23 bedrijfsuerengingen, die leder een bepalde categorie wan professies representeren.

De bedrijfsverenigingen nemen in hun beslissingen bijna altijd de inhoud van het GMD-adves over, "watardoor de GM in sterke mate wordt gerdentiriceerd mec de bedrijevereniging", aldus Buis (1986a).

Deze in feite onafhankelijke instanties zijn beide ingesteld op grond van de Organisatiewet sociale verzekering (1953), met een bestur, warin wetkgeverg en werknemers partair zijn vertegenwoordigd (bedrijesverenigingen), angevuld met door de minister angegeven bestuursleden (GMD). zestien bedrijfsveranigingen hebben ieder bun administratie opgedragen aan het Gemeenschappelijk Administratiekantoor (GAK). De zeven overige verzorgen hun eigen adminigtratie en zijn de zogenaame "zelfadministrerende"

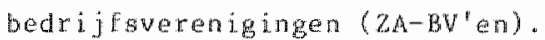

Gedurende het eerste halfjat dat er sprake is van ziekteverzuim van werknemers worden medische onderzoeken verricht door de verzekeringsgeneeskundigen van het GAK en de zelfadministretende bedrijfsverenigingen.

Sinds oktober 1985 is de zogenaande 'zesdemaandsmelding' ingevoerd. Deze regeling houdt onder meer in dat een anzienlijth aantal 'ziektewetgevallen" in de zesde mand door de verzekeringsarts wan de bedrijfsvereniging en/ok het GAK moeten worden gemeld bij de GMD. Het betreft de betrokkenen die niet meer geschikt zijn voor hun eigen werk. Hierdoor is het mogelijk dat er reeds in de 2 wmperiode een onderzoek plaatsvind naar de resterende arbejds(on)geschikcheid in algemene $z$ int.

zowel het vaststellen of er sprake is van arbeidsongeschiktheid als de mate warin geschiedt door de GMD in samenspraak met de bedrijfsverenigingen. Voot ambtenaten en daataan gelijkgestelden volgens de ABP-wet gebeurt dit door het Algeneen Burgerlijk Pensioeatonds (ABP).

Uitgangspunt voor de bepaling van de mate van arbeidsongeschiththeid vormt het zogenamde "getotaliseerd arbeidsvermogen' dat iemand nog heeft om loonverdienende atbeid te kunen vertichten. Vanut het verzekeringsgeneeskundig referentiekader (Timer, 1985b) wordt onder het getotaliseerd arbeidsvermogen verstan: "het geheel van alle beroepsvaadigheden, per- 
soonlijkhe idskenmerken en lichamelijke kenmerken, warower de arbo udende mens beschikt en op korte termijn kan beschikken en welke hij kan ingecten op de positie binnen het arbeidsbestel waxop hij is benoend of zich heeft gevestigd, respectievelijk kan worden benoemd of zich kan westigen."

Bij het vaststellen van arbeidsongeschiktheid ten gevolge wan ziekten of gebreken kumen de volgende stappen (Timmer en Koten, 1984l worden onderscheiden:

Stap |. Ziekten en gebreken worden met professionele wetenschappelijke methoden vastgesteld en weergegeven in termen van lichamelijke, geestelijke en sociale stoornissen.

Stap 2. De geconstateerde scoornissen worden ingedeeld en als zodanig aangegeven naar hun aard, te weten:

- energerische stoornissen;

- motorische stoornissen;

- cognitive stoornissen;

- emotionele stoornissen;

- sociale stoornissen;

- bestendigingstoornissen.

Stap 3. Inventarisatie van de gevolgen van de functiestoornissen op het arbeidsvermogen, weergegeven in termen van (resterende) lichame1ijke belastbarheid, psychische belastbarheid en beroepsvardigheden. Deze latste drie genoemde categorieën zijn tezamen de krachten en bekwamheden warmet arbeid kan worden uicgevoerd.

Stap 4. Beperkingen in belastbaarheid en beroepsvardigheden als gevolg van lichamelijke en/of psychische functiestoornissen dienen te worden afgewogen tegen de noodzakelijke of voorwaandelijke 'werkuitvoeringseisen' van de referentieberopen.

De werkuitwoeringseisen hebben betrekking op:

- de werkuicvoeringsprocessen;

- de werkscuringsprocessen;

- de werkormen;

- de werkonstandigheden;

- de situationele en incidentele eisen.

Indien er tussen de geconstateerde scoormissen en werkwitwoeringseisen een discrepantie bestat, moet op basis wan het verlies a an 
verdienmogelifheden en economische acheerstand de rate van arbeide(on) geschiktheid horden vastgesterid.

De beordeling wan ten xiske of gebrek in termen van gedeelcelijke of gehele arbeidsongeschikeheid wo gens de bepalingen van de wet ken derhalve als wolgt schematisch worden weergegeven:

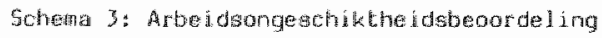

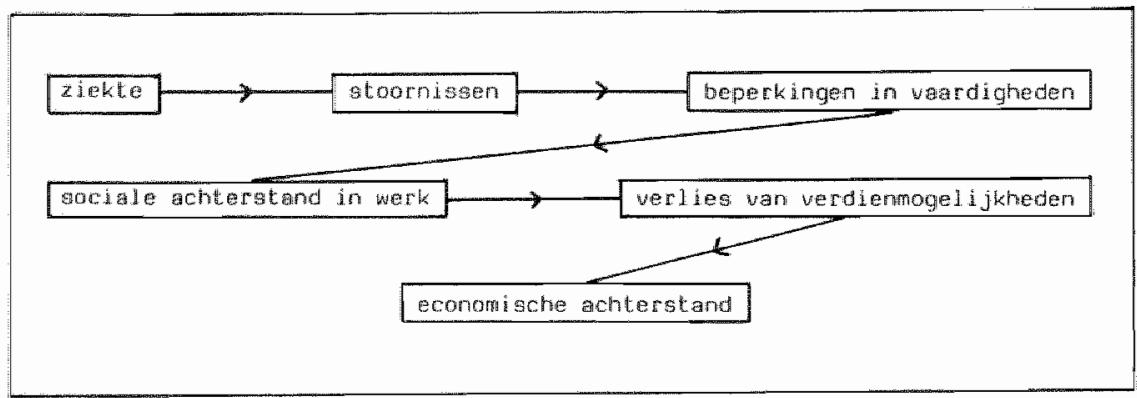

Het voorlopige en/of uiteindelijke percentage arbeidsongeschiktheid en de darriee verbonden uitkerimg wordt bepald door de zogenamde resteremde 'verdiencapaciteit". Deze wordt door de arbeidsdeskundige bepald an de hand van een lijst van functies "wartoe betrokkene in principe op grond wan zijn actuele 'arbeidsvermogen', uitgewerkt nar beroepsaardigheden, persoonlijkheidskenmetken en lichamelijke kenmerken, geschikt kan worden geacht (Timmer, 1985b).

De gang van zaken bij het coetsen van Euncties om de resterende werdiencapacitejt wat te $9 \mathrm{Ct}$ Len verloopt in grote lijentas volgt.

Er vind aen zogenamde "duiding" plats van functies. warroor betrokkene op grond van een medisch belastbarheidspatroon in principe wel woldoende lichamelijke en geestelijke mogelijknedan heet . De arbeidscomplexendow cumentie (ACD) vorat het utgangspunt voor deze functieduiding (Hak, 1970). In deze ACD woden gangare functios landelijk bijgehouden.

* Voce een allgemene inhoudel ijhe omschrijuing van de desbercefiende funties kuner de zogenamde "Beropprainiaturen' van de Hoofdafdeling Beroepskeuzevoorlicht ing en Methodichontwikheling wan het Directorat-Generaal van de Arbeidswooralening van het Ministerie van Sochale Zaken en Werkgelegenkeid worden geradphegd. 
Indien betrokkene op grond van toetsing van het medisch belastbarineidspatroon aan de ACO in staat wordt geacht bepalde werkaameden te verrichten, wordt nagegan wat iemand in die functies kan verdienen. Het aantal bij de arbeidsongeschiktheidsbeoordeling te betrekken functies wordt in het advies van het bestuur van de Federatie van Bedrijhserenigingen d.d. 16 april 1987 aan de bedrijfsverenigingen gesteld op teminste vijf functies met gemiddeld tien arbeidsplaatsen (vacacures) in Nederland.

Daarbij wordt rekening gehouden met de zogenamde "werkstanding", dat wil zeggen dat er geen Euncties worden "geduid", ofwel in de beoordeling van de arbeids(on)geschiktheid mogen worden gehanteetd, die meer dan fén beroepsniveau lager liggen dan warop betrokeme voorheen heef gefunctioneerd.

De vaststeling van het beroepsniveau waarop betrokkene heeft gefunctioneerd en eventueel nog kan functioneren vindt plaats volgens de Arbeidsen Beroepenindeling van de Arbeidsvoorziening van het Ministerie van Sociale zaken en Werkgelegenheid: het ARBImclassificatiesysteem.

Tabel 1: Niveau-indeling van werkzambeden wolgens het ARBI-class if icatiesysteem

\begin{tabular}{|c|c|c|c|c|}
\hline Klasse: & $\begin{array}{l}\text { Karakteristiek } \\
\text { van die arbeid }\end{array}$ & Aanleertiju & Zel fotandigheid & Voorsctooling] \\
\hline 1 & zeer envoudig & $\begin{array}{l}\text { enke le dagen } \\
\text { tot enkede } \\
\text { lateken }\end{array}$ & naciwe l i jks & $\begin{array}{l}\text { (enke le klassen) } \\
\text { basisonderwi jo }\end{array}$ \\
\hline 2 & eenvoudig & enkele maanden & gering & $\begin{array}{l}\text { basisonderwijs plus } \\
\text { evt. enkele kiassen } \\
\text { woontgezet onderwijg }\end{array}$ \\
\hline 3 & enigszins & $\frac{1}{2}$ tot 2 jaar & bescheiden & $\begin{array}{l}\text { LBO of Mavo plus } \\
\text { evt. pr inga ire opl. } \\
\text { leer lingutezers }\end{array}$ \\
\hline 4 & wrij ingemikmeld & geruines tijo & vrij veel & 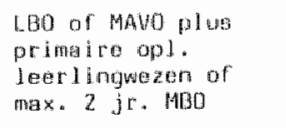 \\
\hline 5 & ingew ikke ld & langdurig & weel & HAwO of $3 \mathrm{j} \mathrm{r} . \mathrm{MaO}$ \\
\hline 6 & zeer ingewikkeld & langdurig & zen weel & $\operatorname{maO}$ \\
\hline 7 & $\begin{array}{l}\text { (praktisch) } \\
\text { wetenschappe li ijk }\end{array}$ & 1.angdurig & zeer weel & $\begin{array}{l}\text { wetenscheppe l i jth } \\
\text { ondrow } \mathrm{i} \text { jo }\end{array}$ \\
\hline
\end{tabular}

Het beroepsniveau is een globale anduiding van de platas die het beroep 
inhednt in het beroepenveld. Het geeft in combinate met andere gegevens, zoals de ard wan het werk, een indicatie wor reategratiemogelijkheden. Er worden zeven functieniveatg gehancerd bij de uitvoering van de sociale verzekeringsweten (Moeskops, 1948; Rijks Arbeids Bureau, 1952).

Deze niveau-indeling, witgewerkt nar karakteristieken wan de arbeid, anleertijd, zelftandigheid en scholingsniveau, wordt weergegeven in tabel ! (Wegersma, 1976$)$.

Binnen de GMD worden sinds 1974 bij de bepaling van het beroepsniveau van de in billijkheid op te dragen werkzambeden de volgende aspecten aan het ARBT-class ificatiesysteem toegevoegd:

- de aard van de functie (wereiste andeg);

- het benodigde inzicht en de benodigde kennis;

- de diepgang van de problemen die men in de functie tegen kan komen;

- de beslissingsvrijheid die men heeft;

- de aandacht die is vereüst (De Vreede, 1979).

Deze aspecten zijn overigens verder niet operationeel gedefinieerd en hoe ze meecellen wordt verder nergens aangegeven.

Mede darom hebben Kooreman en Berk (1987) een checklist met beoordelingscriterial ontwikkeld en geintroduceerd, warmee het beroepsniveau meer betroubaar kan worden vastgesteld.

Bij de 'schatting' wordt het niveau van de in billijkheid op te dragen werkaamheden vergeleken met het niveau van het latste beroep dat betrokkene heeft gehad.

Het witeindelijke arbeidsongeschiktheidspetcentage (schatting) wordt berekend met de formule:

\section{$\frac{\text { matmaninkonen - resterende verdiencapaciteit }}{\text { maatman inkonen }} \times 100 \%$}

In deze berekening stat het natmaninkomen voor het inkomen dat een vergelijkbare werknemer, werkzam in het laatste beroep van betrokkene, op dat momert verdient.

De resterende verdiencapaciteit is een theoretisch begrip, dac wordt bepadd an de hand van het inkomen dat betrokkene in principe kan verdienea 
in functies, welke hij gezien zijn restcapaciteiten en "werkstanding" moet kunnen verrichten.

De resterende verdiencapaciteit wordt afgeleid van een reeks functies met verschillende loonwarden. Hieruit wordt én inkomen gedescilleerd op grond van het 'mediane loonbedrag" : het aiddelste uit de openvolgende van kleir nar groot geplaatste reeks loanbedragen van de geduide functies.

Afhankelijk van de witkomst wordt de 'economische achterstand' bepaald en wordt men ingedeeld in één van de arbeidsongeschiktheidscategorieén, zoals staat weergegeven in tabel. 2. Per uitkeringscacegorie is aangegeven wat het concrete uitkeringspercentage is, warop de berekening van de uitkering plaatsvindt, uitgesplitst naar bedrijfsvereniging (BV) en Algemeen Burgerlijk Pensioenfonds (ABP).

De arbeidsongeschiktheidscategorie 'minder dan 15\%' (AAW<25\%) geeft geen recht op een (aanvullende) witkering volgens de desbetreffende arbeidsongeschiktheidswetten.

Tabel 2: Overzicht arbeidsongeschiktheidscategorieèn en uitkew ringspercentages

\begin{tabular}{|c|c|c|}
\hline \multirow{2}{*}{$\begin{array}{l}\text { Arbeidsongeschikthe idscategorie/ } \\
\text { invaliditeit sgrond }\end{array}$} & \multicolumn{2}{|c|}{ Uitker ingspercentage } \\
\hline & BW & AlBP \\
\hline$<15^{\circ}(A A W<25 \%)$ & - & - \\
\hline $15-25 \%$ & $14 \%$ & $9,39 \mathrm{~g}$ \\
\hline $25-35 \%$ & $21 \%$ & $18,25 \%$ \\
\hline $35-45 \%$ & $288^{\circ}$ & $27,640:$ \\
\hline $45-55 \%$ & 35 & 36,500 \\
\hline $55-65: 0$ & $42^{\text {踖 }}$ & 45,89 \\
\hline $65-80_{0}^{8}$ & $50,75 \%$ & 59,450 \\
\hline $90-100^{*}$ & 70 : & 7396 \\
\hline
\end{tabular}

Indien er door de advies- en uitvoeringsorganen geen conclusie met betrekking tot de arbeidsongeschiktheid kan worden getrokken wegens onvoldoende informatie, kennis en/of inzicht in iemands psychische belastbarheid en beroepsvaardigheden, kan de verzekeringsgeneeskundige een psychodiagmos tisch onderzoek aanvragen.

Als het gaat om onduidelijkheid wat betreft de geschiktheid voor bepalde 
Werkzambeden en indien daaryor eventueel scholing nodig is, kan er can vullend) een psychotechnisch en beroepseuze-onderzok worden aangevraagd. Het verrichten wan een psychotechnisch en beroepsheuze-onderadek vindt overigeng mestal pas plate ingeval de arbeidsdeskundige op basis van het belastbatheidsparroon en coetsing daarvan an het systeem van de arbeidscomplexendocumentatie geen direct halbare functies en/of beroepen kan amroven (duiden).

op grond wan de verkregen psychologische informatie wordt opnieuw bepald of er sprake is van een volledige (voorlopige en/of blijvende) arbeidsongeschiktheid. Darbij bestaat de mogelijkheid dat ex voldoende restcapaciteaten an om drect terug te keren in het arbeidsproces, dan wel dat het uitzich daskop ta be bieden door betrokkene eerst én of andere vorm van scholing lacen wolgen. Het antal arbeidsvoorzieningen in de vorn van fhanciering van om, her of bijscholing neemt de latste jaren toe en netrut op het total wan deze voorzieningen de eerste plaas in (JaarversLg GMD, 1982, 1984,1986$)$.

Voor een meer gedetailleerde en rechnische beschrijving van de wijze warop door de GMD de arbeids(on) geschiktheid word beoordeeld aan de hand van het vastgestelde resterende arbeidsvemogen, witgewerkt nat beroepsvardigheden, persoonijikheidskenmerken en lichamelijke kenmerken, wordt verwezen nar. "Het Verzekeringsgeneeskundig Referentiekader, deel II, III en IV' (Timmer, $1985 a, b, c)$.

Voornoemde praktijkgang bij de GMD onderscheidr zich, afgezien van enkele organisatorische verschillen, niet wezenlijk van de wijze waarop door de verzekeringsgeneeskundigen en arbeidsdeskundigen van het Algemeen Burgerlijk Pensioenfonds de mate van arbeids(on)geschikcheid van de aldar verzekerden wordt vastgesteld.

In geval van ziekte van een ambenate wordt veelal in eerste instantie medisch onderzoek verticht door Bedrijfsgezondheidschensten, Gemeentelijke en Districts Geneeskundige Gezondheidsdiensten of de Rijks Geneeskundige Dienst. Ook deze instanties kunnen voor hun beeldvorming van betrokkenes 'psychische belastbarheid', eventueel ter voorbereiding van een ABPkeuring, een beroep doen op psychologen. 
Deze psychologen kunnen werkaam zija in de curatieve sector, bij de Rijks psychologische Dienst of zelfstandig gevestigd zijn.

Bij het ABP heet het onderzoek nat de arbeidscongeschiktheid formeel "de pensioenkeuring" en betreft een medisch onderzoek, warrwan het doel tweeLedig is:

1. Jagaan of iemand wit hoofde van ziekten of gebreken blijwend ongesehik is voor zijo/har Functie, respectievelijk herplaatsbar kar worden geacht, en in welke mate er sprake is van algemene invaliditeit;

2. creffen van matregelen om arbeidsongeschikcheid tegen te gan dan wel voorzieningen treffen tot behoud, herstel en bevordering van de arbeidsgeschiktheid.

Een dergelijke pensionkeuring kan zowel door betrokkere zeli als zijn werkgever (meestal wia de bedrijfsgeneeskundige dienst) bij het $A B P$ worden aangewraagd. In het kader van een dergelijk onderzoek kan er bij een psycholoog door de betrokken verzekeringsgeneeskundige een psychodiagnostisch onderzoek en door de arbeidsdeskundige een psychotechnisch en beroepskeuze-onderzoek worden aangewraggd, alvorens het ABP de besissing neent.

De keuringsprocedure mondt uit in én van de volgende besilissingen:

a. wit hoofde van ziekten of gebreken blijwend ongeschikt, warbij tevens het percentage algemene invaliditeit wordt vastgesteld; niet herplatsbaar.

(N.B. Het juridisch begrip 'herplatsbaar" in de zin van de ABP-wet houd in dat de betrokken anbtenaar na ontslag wegens ziekte of gebrek wit zijn functie geen invaliditeitspensioen ontvangt. Indien er aasiuitend geen werkhervate ing in ander passend werk volgt, komt herplaatsingswachtgeld cen laste van $x i j n$ lagtste werkgever voor een periode yan ten hoogste vijf jaar. In geval wan werkhervatting kan door het $A B P$, onder bepalde voorwarden, een herplatisingstoelage worden toegekend.)

b. Wt hoofde van ziekten of gebreken blijvend ongeschikt, doch herplattsbaar, warbij tevens het percentage algemene invalidite th wordt vastgesteld.

c. niet blijvend ongeschikt.

Afhankelijk van de uiteindelijke beslissing vindt er wel of geen verdere begeleiding wanuit het ABP plats. 
Particulite verzekeringshaachappijen hebben voor de vaststelling van de mate van arbeids(ongeschiktheid eigen binnen de wet toegestane regels en criteria. Meestal komen deze niec overeen met de regels en criteria die door de adves- en uitvoeringsorganen van de sociale wergeving bij de arbetidsongeschiktheldsbeoordeling worden gehanteerd.

Dit verschil in beoordelingsbeleid kan vooral de nodige problemen en moe lijkheden geven (o.a. bij de premievrijstelling), wanneer iemand deels verplicht werzekerd is en zich deels particulier tegen risico"s van arbeidsongeschiktheid heeft verzekerd. Met deze problematiek kunnen psychologen worden geconfronteerd, die zich bezig houden met arbeids(on)geschiktheidsdiagnostiek wan zowe verplicht als particulier verzekerden.

\subsection{BEROEPSMOGELIJKHEDEN EN RECHTSGANG}

Wanneer betrokkene zich niet kan verenigen met een beslissing van één van de uitvoeringsorganen inzake zijn of haar arbeids(on)geschiktheidsbeoordeling, kan op grond wan de Beroepswet wan 1955 tegen die beslissing beroep worden angetekend bij respectievelijk de Raden van Beroep, het Ambtenarengerecht en in geval van hoger beroep de Centrale Raad van Beroep. Er zijn tien Raden van Beroep, tien Ambtenarengerechcen en één Centrale Raad van Beroep.

De Raden van Beroep zijn samengesteld uit een juridisch geschoolde voorzitter en leden die gelijk verdeeld op Koninklijk Besluit zijn benoem op voordracht wan respectievelijk de werkgevers- en werknemersorganisaties (Beroepswer 1955, artikel 4 en 19).

De ambtenarengerechten hebben dezelfde standplats en hetzel fde rechtsgebied als de Raden van Beroep (Ambtenarenwet, artikel 4). De voorziters van de Raden van Beroep treden tevens bij de respectievelijke Ambtenarengerechten ter standplaats op in dezelfde hoedarigheid (Ambtenarenwet, artikel 4 lid 2). Benoembar tot lid is iedere ingezeten Nederlander die voor de aarwang van het lopende kalenderjaar de Leettijd van 25 jar heeft bereikt (Ambtenarenwet 1929: artikel. 7).

De Centrale Rad van Beroep bestat uit minstens drie leden die juridisch wijn geschoold en in ambtelijke dienst zijn (Beroepswer, artikel 34 1.id 2). 
Een beroepsprocedure wordt aanhangig gemakt door midel van een "klagg schrift", nadat een "voor berop vatbare beslissing" (VBvB) van het uitvoeringsorgan is verkregen.

De VBVB geeft in de wetcelijk voorgescheven worm aan wat het utuberingsorgaan heeft beslist, hoe het daaroe is gekomen, op grond van welke ingewonnen gegevens (adviezen) en welke wettelijke bepalingen darbij in aamerking zijn genomen. Bovendien noet te vBub vermelden bij welke Raad van Beroep betrokkene binnen welke termin door midded van een klagschrift beroep kan aatekenen.

Het indienen van een klagschrift heeft geen schorsende werking ten aanzien van de oorspronkelijke beslissing van hec uitvoeringsorgan.

Hangende de uitspraak van de desbetreffende beroepsinstantie wordt dus de uitkering gegeven overeenkonstig de beslissing van de uitwoerende instantie. Indien er dan geen recht bestat op een gehele of gedeeltelijke arbeidsongeschiktheidsuitkering, c.q. een invaliditeitspensioen, betekent het meestal dat betrokkene een uitkering krijgt krachtens de nieuwe Werkloosheidswet of de Algemene Bijstandswet.

De taak van de beroepsinstanties is on de beslissing wartegen de betrokkene beroep heeft aangetekend te toetsen aan de wet. Vit de jurisprudentie van de beroepsrechter blijkt echter dat toetsing van voor beroep vatbare beslissingen van uitvoeringsorganen is beperkt tot rechmatigheidscontrole (De Jong, 1984). Daarbij toetst de rechter a an de algemene beginselen van behoorlijk bestuur, wartoe gerekend worden: het motiveringsvereiste, het zorguuldigheidsbeginsel, het gelijkheidsbeginsel, het vertrouwensbeginsel. en het rechtszekerheidsbeginsel (Haverkamp, 1982).

Tegen deze achtergrond heeft de beroepsrechter de bevoegdheid cot het zelfstandig onderzoeken van de standpunten en argumenten van de partijen en hij mag darbij alles als bewijsmaterial gebruiken. In dat werband is de uitvoerende instantie verplicht alle stukken over verricht onderzoek aan de beroepstechter te overleggen, welke voor de partijen ter inzage worden gelegd (Beroepswet, artikel 98 en 111 ).

De beroepsprocedure wordt door Buis (1986a) vanuit een besturrakundige inwallishek beschreven als een informatieproces dat verschillende tasen 
kent en bij wootgang lểdt tot én van de volgende drie uitspraken van de desbetreferde beroepsinstantie:

- beroep niet ontvankelijk serklaard;

- beroep gegrond verklaard;

- beroep ongegrond verklaard.

Indien het beroep gegrond wordt geoordeeld, kan, met gehele of gedeeltelijke vernietiging van de bestreden beslissing, hetzij een uitspraak worden gegeven welke treedt in de plats van die beslissing, hetzij worden bepald dat het organ, door of namens hetwelk de bestreden beslissing is genonen, eer nadere beslissing dient ce nemen of te doen nemen met inachtneming wan de uitspraken (Beroepswet, artikel 70 ).

Tegen een uitspraak van de Raad van Beroep of het Ambtenarengerecht kunnen de partijen door middel van een 'beroepschrift" in hoger beroep gaan. De Centrale Rad wan Beraep behandelt lagere beraepsaken van zowel de Raden van Beroep als de Ambtenarengerechten. Het hoger beroep schorst de uitsprak wartegen het is gericht (Beroepswet, artikel 147).

voor zover het een oordeel betreft over het wel of niet arbeidsongeschikt zijn, kan tegen een einduitspraak van de Centrale Raad van Beroep geen beroep worden aangecekend.

Voor een meer uitgebreide beschrijwing van de beroepsprocedure wordt verwezen naar De Jong (1984), Caldenborgh e.a. (1985), Buis (1986a), Schnitzler (1986) en Mannoury en Asscher-Vonk (1987).

2.5 ONERZICHT WAN DE PROCESGANG BIJ DE ARBEIDS(ON)GESCHIKTHE IDSBEOORDEL ING

Door de arbeids(on)geschiktheidsbeoordeling als een proces te beschouwen kunnen daarbinoen verschillende momenten worden onderscheiden.

Aansluitend op voorgaande beschrijuing van de algemene prakijkgang bij de arbeids(on)geschiktheidsbeoordeling kunner, ingeval er door de adviesof uitvoeringsorganen een psychologisch advies is gevraagd, de meest relevante momenten van de procesgang als volgt vereenvoudigd worden werergegen: 


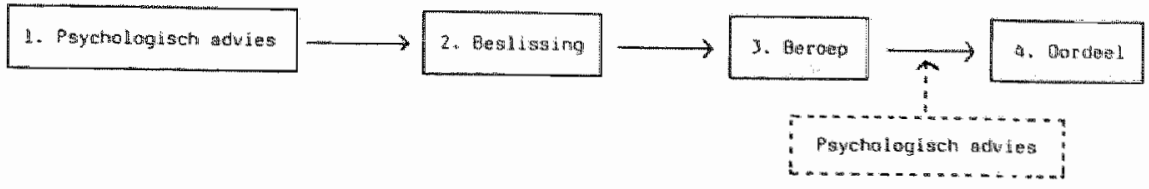

ad. 1

Het psychologisch onderzoek is gericht op de vaststelling van de resteren de psychische belastbarheid en beroepswardigheden, op grond warvan het psychologisch advies inzake de arbeids(on)geschiktheid wordt geformuleerd.

ad. 2

Mede op basis van een uitgebracht psychologisch advies komen advies- en uitvoeringsorganen in gezamenlijk overleg tot een beslissing inzake de mate van arbeidscongeschiktheid van betrokkene.

ad. 3

Indien betrokkene de, mede op het psychologisch advies gebaseerde beslissing van de uitwoeringsorganen niet acceptabel vinde, kan hij in beroep gaan.

ad. 4

Het is dan aan de beroepsinstantie(s) on uit te maken of het beroep gegrond of ongegrond, dan wel 'niet ontwankelijk' wordt verklaard. In dat: verband kan door de rechter eveneens een psycholoog worden geconsulteerd, alvorens $h i j$ beslist.

Len psychologisch adwies kan door de adviserende en utvoeringsorganen wan de arbeidsongeschiktheidswetgeving wel of niet worden overgenomen. De beslissing ligt in handen van het desbetreffende uitvoeringsorgana, terwijl in geval. van beroep tegen een "voor beroep vatbare beslissing" de desbetreffende beroepsinstant ie het uiteindelijke oordeel bepalt.

Een meer uitgewerkt overzicht van de procesgang bij de arbeidg(on)geschiktheidsbeoordeling is in schema 4 weergegeven. Voor de overzichtelijkheid is in dit schema geen onderscheid gemakt tussen de beslissingen van het 
adviesorgan (GM) en van de uitwoeringsorganen, welke overigens meestal conform zijn ( $z$ i.e ook Buis, 1986a).

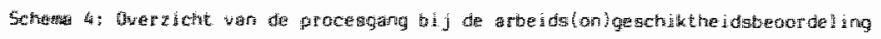

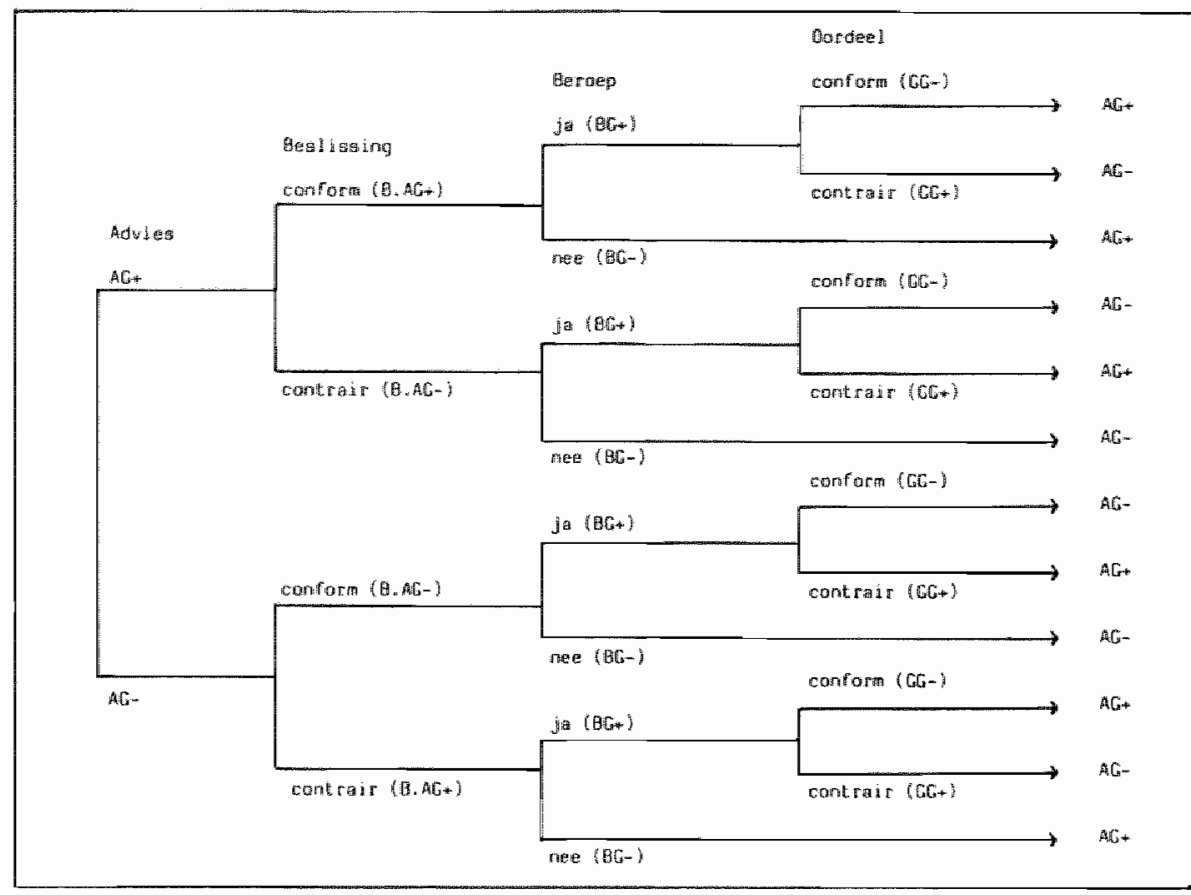

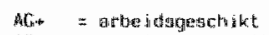

$\mathrm{AC}-\mathrm{C}-\mathrm{arbe}$ idsongeschikt.

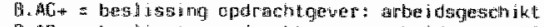

BC: = beslissing bet rokkinen: beroep alangetekerad

BC- = beslizsing bet raktiene: geen berwep anget ekend

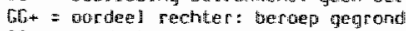

H. ME- = bes

$\mathrm{GC}-\mathrm{z}$ morded rechter: beroeg armegrond

Een psychologisch advies arbeidsgeschikt (AG+) kan door de advies- en uitvoaringsorganen wel of niet worden owergenomen. Ingeval de beslissing conform het advies is (B.AG*), kan dit aanleiding zijn tot een beroepsaak (BGw). Indien betrokkene geen beroep aantekent (BG-), blijft het advies arbeidsgeschikt ( $\mathrm{AG}+)$ gehandhafd.

Wordt in geval van een beroepsaak betrokkene door de beroepsinstantie als atbeidsgeschikt beschouwd, dan wordt het beroep dus ongegrond (GG-) verklatd. Is het beroep gegrond (GG+) verklaard, dan wordt het advies arbeidsgeschikt (AGt) ongedaan gemaakt.

Dezelfde procesgang wordt gevolgd ingeval een psychologisch advies van 
arbeidsongeschiktheid ( $A G^{-}$) wordt overgenomen door het advies-- en/of uitvoeringsorgan. Ook dan makt bij een beroepsaak de beroepsinstantia uiteindelijk uit of betrokkene contorm het adves arbeidsongeschikt is.

Bij het niet overnemen van het psychologisch advies door het advies- enfof uitvoeringsorgaan kan het psychologisch oordeel mogelijk alleen nog van invloed zijn in geval van een beroepszak, indien de beroepsinstantie het psychologisch onderzoek en het daarop gebaseerde advies, tegen de beslissing van het advies- en/of uitvoeringsorgan in, toch als zodanig overneent.

Alle verrichte onderzoken in het kader van een arbeids(on)geschiktheidsbeoordeling kunnen in principe door de beroepsinstanties worden betrokken bij hun uiteindelijke oordeelsvorming.

Meestal laat de beroepsinstantie zich in geval van tegenstrijdige uitspraken adviseren door (vaste) deskundigen, van wie de uitspraken een sterke invloed hebben op de uiteindelijke oordeelsvorming (Knepper, 1984; Hoencanp en Schipper, 1985).

Uitspraken van de beroepsrechter kunen een "precedent-werking" hebben. Dat wil zeggen, dat de advies- en titvoeringsorganen daaruit funnen opmaken hoe beroepsinstanties in soortgelijke gevallen kunnen oordelen, hetgeen van invloed kan zijn op het beslissings- en beoordelingsbeleid van de advies- en uitvoeringsorganen.

Het juridisch referentiekader woor arbeidsongeschiktheidsbeoordelingen wordt overigens niet alleen bepala door de wet, mat blijkens de jurisprudentie ook door de algemene rechtsbeginselen, de algemene begünselen van behoorlijk bestuur en de algemene beginselen van een goede procesorde. Zowel de wet als de jurisprudentie kunen op zich aan veranderingen onderhevig zijn onder invloed van wijzigingen en veranderingen in de weten schappelijke en matschappelijke visies met betrakking tot "arbeidsongeschiktheid' in relatie cot 'ziekte en gebrek'.

In het volgende hoofdstuk 3 wordt hier nader op ingegan. 


\section{ARBEIDSONGESCHIRTHEID EN PSYCHISCHE STOORNTSSEN}

\subsection{ARBETDSONGESCHIKTHETD IN RELATTE TOT ZIEKTE EN GEBRBR}

Noodzakelijke voowarde voor een uitkering krachtens de $2 W$, ANW, WAO en ABP-wet is de aanwezigheid van ziekte of gebrek. Er zijn vele pogingen gedaan de begrippen "ziekte' en 'gebrek' operationeel te definiëren. Tot heden is er nog geen eenduidige, geaccepteerde en werkbare formule gevonden (Bijlsma en Koopmans, 1982; Snitslaar en De Klerk, 1982; Buis, 1986b; panhuis 1987). Dit heeft zijn consequenties voor de beoordeling van de arbeids(on)geschiktheid.

Sinds de inwerkingtreding van de WAO op 1 juli 1967 wordt er geen onderscheid meer gemakt tussen de begr lippen ziekte en gebrek. Woordien werd een gebrek als een aangeboren abnomaliteit met een statisch karakter beschouw, terwijl ziekte als een min of meer procesmatige, tijdelijke evenwichtsverstoring van het organisme met een kans op herstel, evencueel op een lager niveau, werd gezien (Hymans van den Bergh en Bart de la Faille, 1936).

Formeel zijn de begrippen ziekte en gebrek noch in medische termen, noch im wettelijke termen in het sociale verzekeringsrecht vastgelegd, wardoor variatie in de vaststelling ervan mogelijk is (Van Zaal, 1974).

"Het ontbreekt ten aanzien van de begrippen ziekte en gebrek aan een gouden objectieve standard en darmee an een eenduidig toetsbar criterium", aldus Sergeant (1987).

Zhekte en gebrek zijn niet identiek an het wetelijk begrip arbeidsongeschiktheid, al liggen deze begrippen wel in elkars verlengde.

De gedachte dat de grens tussen ziekte en gebrek enerzijds en gezondheid anderzijds objectief is vast te stellen, wordt steeds meer verlaten (Groothoff, 1986).

Er zijn vloeiende overgangen ussen psychisch gezond en psychisch ziek zijn en daamee onk tussen arbeidsgeschiktheid en arbeidsongeschiktheid. Hetzelfde geldt mutatis mutandis wook het onderscheid tussem 'normal' en "abnormal" op het wak van de persoonlijkheidsstruccuur en de mate warin 
op grond van diefecten en stoornissen daarin sprake is van arbeidscongeschiktheid (scherster, 1970).

Arbeidsongeschiktheid is in feite het resultaat wan een samenspel tussen individuele eigenschappen wan betrokkenen en structurele kenmerken van de matschappij (Van Zaal, 1984) en berust derhalve op steeds veranderende consensus. Maatgevend in dezen is tot nu toe de jurisprudentie van de adminigtratieve rechtsprak, die op haar beut worde bernvloed door wetenschappelijke en matschappelijke ontwikkelingen (Polak, 1979).

Historisch gezien werder in het kader van de administratieve rechtspraak betreffende de psychische ziekten en gebreken in eerste instantie alleen psychosen, cerebraal-organische stoornissen en ernstige vormen van zwakzinnigheid met arbeidsongeschiktheid in verband gebracht. De beordeling daarwan door deskundigen gat weinig of geen problemen of onduidelijkheden. De algemene definitie van gezondheid door de world Health organization (1946), omschreven als 'een toestand van volledig lichamelijk, geestelijk en sociaal welzijn en niet slechts afwezigheid van ziekten en gebreken', en de uitbreiding van het begrip ziekte door Rümke (1951) en Van der Horst (1953) naar begrippen als neurose, psychopathie en persoonlijkheidsstoornis, hebben een grote invloed gehad op de begripsbepaling van "psychische ziekte' en clarmee op de problematiek van de vaststellingen van arbeids(on)geschiktheid.

De meest recente international. aanvarde omschrijuing van het begrip 'psychische ziekte' luidt volgens de Diagnostic and Statistical Manual of Mental Disorders (third edition-revised: DSM-III-R, American Psychiatric Association, 1987): "A clinically significant behavioral or psychological syndrone or pattern that occurs in a person and that is associated with present distress (a painful symptom) or disability (impairment in one or more important areas of functioning or with a significantly increased risk of suffering death, pain, disability, or an important loss of freedom. In addition, this syndrome or patern must not be merely an expectable response to a particular event, e.g., the death of a loved one. Whatever its original cause, it must currenty be considered a manifestation of a behavioral, psychological, or biological dysfunction in the person." 
Met betrekking tot de becordeling van de arbejds(on)geschiluheid impliceert deze formulering volgens kortmann (1987), dat er twee wragen moeten worden beantwoord:

1. Is er bij betrokkene sprake van een kinisch significant syndroom in psychische, fysiologische en/of gedragsmatige zin en zo ja, welk?

2. Gaat dit syndroom gepaard met beperkingen in én of meerdere functiegebieden van betrokkene, watdoor hij of zij niet kan werken?

Mede op advies van de Werkgroep Rapportage en de Sociale Wetgeving (Hoencamp e.a., 1988) wordt landelijk steeds meer bij de beantwoording van voornoemde vragen witgegaan van het classificat iesysteen van de DSM-III-R. Deze ontwikkeling komt voort wit de toenemende behoefte aan vergroting van de vergelijkbaarheid en betrouwbarmeid van adviezen inzake arbeids(on) geschiktheid en beslissende uitspraken daaromt rent.

De consequentie ervan is dat mensen met psychische, fysiologische gedragsmatige symptomen, welke in de DSM-TII-R staan beschreven, in principe als 'ziek' kunnen worden beschouwd, en als 'arbeidsongeschikt' wanneer ex sprake is wan functiestoornissen, welke met betrekking tot de referentieberoepen en daraan gerelateerde werkut voeringseisen beperkingen geven.

Ondat de DSM-TII-R grotendeels een beschrijvende en met betrekking tot de etiologie een a-theoretische benaderingswijze is, kont de categorie 'neurotische stoornissen' als zodanig niet voor (Rooymans, 1986), "terwijl deze neurotische stoornissen een belangrijk deel van de huidige populatie van arbeidsongeschikten uitmaken", aldus De Klerk e.a. (1986).

De neurotische aandoeningen zija nu overigens in de DSM-IYY-R cerug te vinden in de angststoornissen, affectieve stoornissen, somatoforme stoomigu sen, seksuele stoornissen en ampassingstoornissen en kumen als zodanig getormuleerd de grond woor arbeidsongeschiktheid vormen.

Vooral wat betreft de neurotische stoornissen hebben de normen voor arbeidsongeschiktheid de laatste jaren een werruming ondergaan. Dit is onder meer het gevolg van een proces van toevaegingen van neurotische werschijnselen (Smit, 1952), zoals het hyperesthet isch-emotioneel syndroom (Weyel, 1970), overspannenheid (Kraft, 1972, 1975), stress (Selye, 1976) 
en decompensatie (Jongerius, 1984) als randgebieden der psychiatrie, an het begrip tiekte (schrbeder e. a . 1988).

Deze roewoging is enerzijds het gevolg van de hemieude orientatie na de Tweede Nereloorlog op de invloed van matschappelijke en omgevingsfactoren op de gezondheid en her welzijn van het individu en anderzijds berust deze normverruiming op de toemame van het aantal mensen dat met gezondheidsklachten die onder één van voornoemde begrippen vallen, niet in stat is om te werken.

In hoeverre beperkingen in het arbeidsvermogen, voortkomend uit een bijzondere karakerologische ontwikkeling reden kunen zijn voor arbeidsongeschiktheid, is nog steeds ter discussie en afhankelijk van onderzoek (Menges, 1986). In ieder geval constateert Van zandwoort (1987) dat er steeds meer inzicht en begrip ontstat voor de lange en dikwijls blijvende duur wan ziekteverzuin wegens psychische decompensacie bij mensen met een 'neurotische persoonlijkheidsstructuur', as gevolg van een meer dan normal. Wershelde afname in psychische belastbarheid, vergeleken met de niet-neurotisch gestructureerde leeftijdgenoten.

ook kunnen bepalde 'defecten' in de persoonlijkheidsstructuur (Panhuis, 1987) op korte of langere termijn beperkingen geven ten aanzien van specifi.eke werkzamheden onder bepaalde onstandigheden (bijvoorbeeld werken in ploegendienst; Jansen, 1987), mogelijk resulterend in een verhoogd verzuimrisico, respectievelijk verminderde geschiktheid en ongeschiktheid.

Daarnast hebben de ontwikkelingen op het gebied van de psycho-somatiek geleid tot het inzicht dat een bepalde karakterstructuur kan bijdragen tot het ontstaan van bepalde arbeidsbelemmerende fysiologische klachten, symptomen en thoonisisen (Boer e.a., 1983 ).

ontoereikende opleiding en beperkte bekwameden (analrabetisme, zwakegafdheid) worden nite op voorhand als ziekte of gebrek beschouwd. Wel. kunnen ze onder bepalde onstandigheden secundair tor ziekte (bijvoorbeeld surmenage) leiden, wanneer er door ontwikkellingen in de werksituatie een groter beroep wordt gedaan op cognitief-intellectuele aampassingsvermogens en/of specifieke vaardigheden dan wartoe betrokkene in staat is.

De bepaling van de arbeids(on)geschiktheid vereist afweging van de mate 
wan onvermogen als gevolg wan wiekte of gebrek tegenover de bielasting wan de desbetreffende werkzaanheden, waraan gezien de vragstell Ing moet worden gerefereerd. Tevens dient darbij de kans op recidief ziekteveruim bij terugkeer in het arbeidsproces te worden geschat en in de beoordeling te worden meegenomev.

Teneinde tot een gedeelcelijke of gehele arbeidsongeschikheid te kunnen besluiten, is het ingevolge de wet noodzakelijk dat er een ziektebeeld dan wel gebrek ter verklaring wordt gegeven. Dit impliceert dat er in ieder geval een aannemelijke verklaring op somatische em/of psychische gronden nnoet kunnen worden angegeven on te kumen concluderen dat ar sprake is wan arbeidsongeschiktheid in de win der wet.

Met name in geval van psychische stoornissen is volgens Bax (1984) het beoordelen van de arbeidsongeschiktheid een witerst discutabele aangelegenheid. Er is nogal eens sprake van verschillen in diagnose, verwachtingen over beloop, herstel en therapie. "Mensen met psychische ziekten vormen voor verzekeringsgeneeskundigen een probleemgroep, ondat ze met meer onzekere factoren te maken hebben dan bij de meeste andere ziekten", aldus De Klerk e.a. $(1986)$.

Aangezien deze groep abbeidsongeschikten in onvang sterk toeneent, neemt ook de problematiek van de arbeids(on)geschiktheidsbeoordeling in verband thet psychische stoornissen toe en is het te begrijpen dat deze oncwikkeling zowell beleidsmatig als wetenschappelijk bijzondere andacht vragt.

\subsection{ARBEIDSONGESCHTKTHETD IN VERBAND MET PSYCHISCHE STOORNISSEN}

Psychische stoornissen komen toenemend voor, onder meer in samenthang met arbeidsvervullingsproblemen, en worden steeds belangrijker als oorzak wan arbeidsongeschiktheid. De sterke wolumegroei van het aantal personen met een arbeidsongeschiktheidsuitkering als gevolg van "psychische deficiënties' is een sociaal-matschappelijk probleem (Hibbeln, 1980). Dit is geen specifiek Nederlands verschijnsel, maar doet zich in vrijwel alle geindustrialiseerde 'verzorgingsstaten. woor (De Gier, 1981).

Met name in deze landen is een stijgende lijn te constaterem in het a antal mensen dat buitem het arbeidsproces geraakt wegens psychische stoornissen. 
In Nederland is rutu de helft van de groei van het totaal aantal uitkeringsgerechtigden sinds 1982 afkomstig uit de categorie "psychische stoor" nisgen'. Momenteel vormen deze stoornissen de belangrijkste diagnose onder de categorie 'Langdurig volledig arbeidsongeschikten' (Knepper, 1987).

Sinds 1967, het jar watin de Wo in werking trad, neemt het antal arbeidsongeschikten wegens psychische stoornissen vrijwel lineair toe. Volgens het onlangs aan de vaste kamercomissie voor Sociale zaken en Volksgezondheid aangeboden rapport "Preventie van ongeschikte arbeid" (Den Heeten e.a., 1988) komen jaarlijks ruim 16.000 mensen wegens psychische problemen in de AAW/WAO cerecht. Volgens hetzelfde rapport heeft, afgezien van de aandoeningen en diagnosecodering, naar schatting de helft van de 725.000 mensen die in de AAw/WAO zitten "psychische problemen'. Dit betreft vooral jongeren tot 25 jaar, jonge vrouwen en mensen bowen de 55 jar.

In 1968 was het aantal arbeidsongeschiken met de hoofddiagnose 'psychische stoornissen' volgens de gegevens wan de GMD (De klerk e.a., 1986) nog $11 \%$ van het cocall aantal uitkeringsgerechtigden voor de WAO. In 1985 was dit percentage $27 \%$, warmee het contingent van lijders aan psychische stoornissen, na dat van lijders aan stoornissen in het bewegingsstelsel, de grootste categorie van arbeidsongeschtkten is geworden. Deze ontwikkeling wordt weergegeven in grafiek 1 , warvan de gegevens over de jaren 1981 cot en met 1985 zijn ontleend aan het GMD Jaarverslag 1985 (zie bijlage A) en de gegevens over 1968 en 1986 aan De klerk e.a. (1986).

Volgens het GMD Jarverslag 1986 vertoont overigens het andeel van de psychische stooritsen in het total van het ancal nieuwe uitkeringsgerechtigden enige dating en veroorzaakt in het total een teruggang van $27 \%$ naar 26\%. "In hoeverre dit meer dan incidenteel is, zal nog moeten blijken"

Ook bij deze daling blijkt overigens de diagnose "psychische stoornissen' bij de nieuwe uitkeringsgerechtigden onder de groep 18- tot 35-jarigen de eerste plats in te nemen.

Voor de 'jeugdgehandicapten' zijn de psychische ziekten zelfs de grootste diagnosecategorie voor arbeidsongeschiktheid. Deze jonge uitkeringsge- 
rechtigden, die in vele gevallen nog nooit aan het arbeidsproces hebben deelgenonen, maken thans meer dan 50 git van het antal niewwe AAw-uthew ringsgerechtigden.

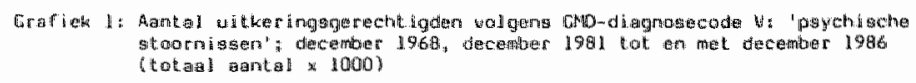

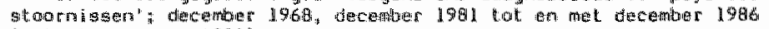
(thoramb gantal $\times 1000$ )

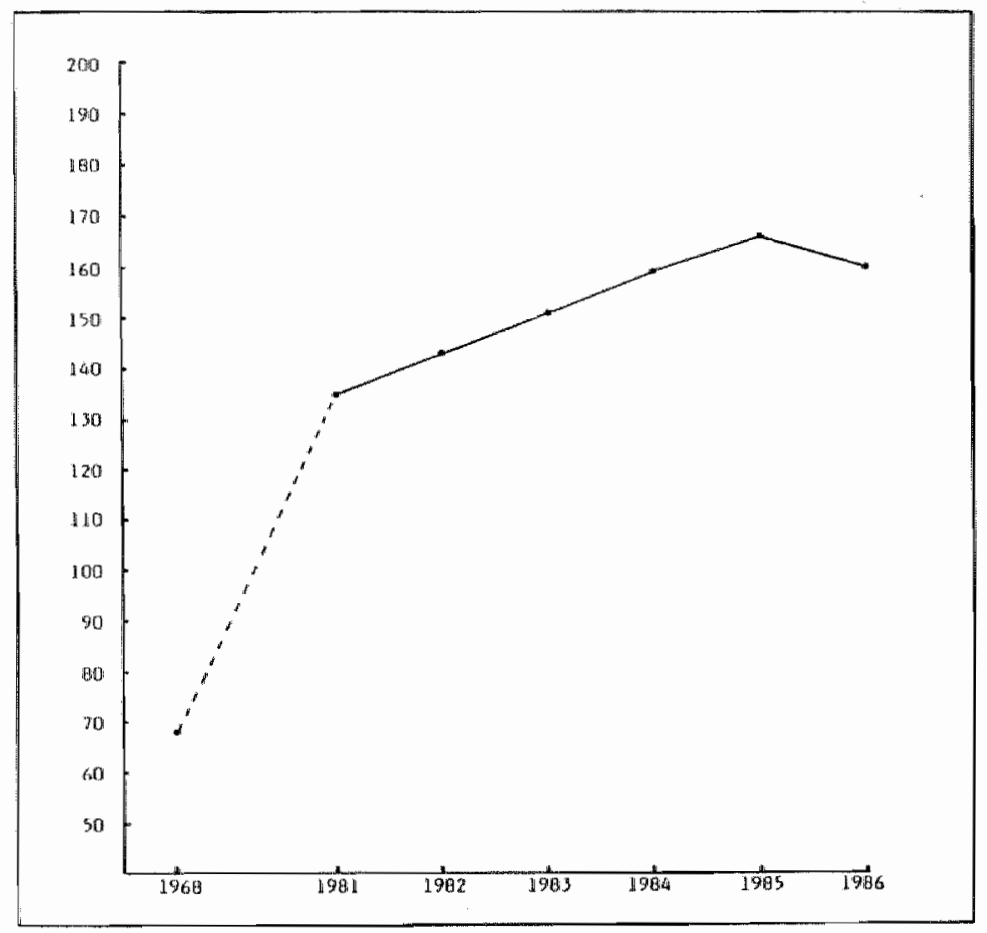

De groep, die wegens psychische stoormissen AM- en/or who-gerechtigd is, wordt in het door de GMD gehanteerde classificatiesysteem (de TCD -9*) angeduid als diagnosecategorie $V$. Deze dignosecategorie bestat uit 26 gespecificeerde diagnose-mogelijkheden, warvan de meest voorkomende zijn: psychosen, neurotische stoornissen, aanpassingsstoornissen en depressieve stoornisisen.

vit cen clossierstudie van De Klerk e.a. (1986) is naar voren gekomen dat 
mensen die tot cakegorie behoren, in tegenstelling tot andere diagnosecategoriearn:

- jonger zijn:

- relatief vaker van het vrouwelijk geslacht zijn (Besseling en Brünsma, 1986);

- meer alleenstand zijn (mannen zijn in de meeste gevillen gescheiden en wrowwen ongehusd);

- hoger zijn opgeleid;

- cen hoger beroepsniveau en inkomen hebben;

- vaker full-time werken;

- meer in onregelmatige diensten werken;

- meer in grote steden wonen;

- meer onder de Nieuwe Algemene Bedrijfsvereniging en de Bedrijfsvereniging voor het Bank- en Verzekeringswezen ressorteren;

- meer contact hebben met de behandelende sector van de gezondheidszorg;

- met uitzondering wan de arbeidsongeschikten met hart- en vatziekten de meeste psychofarmaca gebruiken (Bruinsma e.a., 1987);

- Ilanger volledig arbeidsongeschikt zijn (Knepper, 1987);

- bij beroepszaken meer in het gelijk worden gesteld (Knepper, 1983 en 1984; Hoencamp en Schipper, 1985).

Uit het ABP Jaarvetslag 1985 blijkt de groep "psychische ziekten" binmen de ABP-populatie (ca. 25\% van de Nederlandse bevolking) zelfs de eerste plats in te nemen onder de ziektecategorieën voor blijvende arbeidsongeschiktheid (ca. 35\%). Voor de exacte aantallen wordt verwezen naar bijlage B, warin over de periode 1981 tot 1985 thet aantal blijvend arbeidsongeselikt-verklabrden stat weergegeven.

Dat uit de ABP-gegevens de toename vam psychische ziekten als reden voor arbeidsongeschiktheid niet zo expliciet naar voren kont als in de GMDgegevens, heeft te maken met het verschil van criteria die in de jaarverslaglegging worden gehanteerd. De GMD hanteert de stand van zaken per einde wachttijd voor de AAW/WAO aan het einde van het kallenderjaar. Het ABP hanteet op hetzelfde tijdstip het aantal blijvende ongeschiktverklaringen, wardoor de 'tijdelijk ongeschikten' wegens psychische stoornissem buiten deze gegevens zijn gebleven. Deze categorie tijdelijk arbeidsonge- 
schikten is in vele gevallen niet bij het ABP bekend, waar is wel terug te vinden in het bestand van de bedrijfsartsen.

Volgensi Van oosterom (1984) betreft zeker $55 \%$ van de patientenpopulatie wan bedrijfsartsen mensen met psychische problematiek.

Dit wordt doot Van der Putten (1985) bevestigd doon zijn onderzoek naar het antal ambtenaren dat bij de "arbeids(on)geschiktheidskeuring" weliswar niet blijwend volledig is argekeurd, maar bij wie wel een 'werm laagde', c.q. afgenomen psychische belastbatheid werd geconstateerd. Bij $58 \%$ wan de mannen en $63 \%$ wan de vrouwen was er sprake van een verminderd arbeidsvermogen wegens hun afgenomen psychische belastbarheid.

Een analyse van de soort psychische problematiek, wardoor mensen niet in stat zijn on te werken, heeft geleid thot de constatering dat een niet onaanzienlijk deel van de populatie arbeidsongeschikten op psychische gronden binmen de categorie 'lichte psychopathologie' valt cBroekhus, 1986).

De klerk e.a. (1982, 1986) komt eveneens tot de conclusie dat de progressie van het antal uitkeringsgerechtigden in diagnosegroep $V$ in mindere mate de ernstige psychopathologie betreft, mar dat het vooral de lichte psychiatrische stoornissen, zoals neurotische stoornissen, angststoornissen, depressieve stoornissen, inadequate aanpassingsreacties (overspannenheid/surmenage, stress, decompensatie en levenstaseproblematiek) en somatisatie zijn die tot arbeidsongeschiktheid leiden.

van het totaal aantal 'psychische gevallen" bleek in $198375 \%$ tot deze "lichtere psychopathologie' te behoren. Daarbinnen is de categorie mensen met neurotische stoornissen (36\%) oververtegenwoordigd (De Klerk e.a., 1985), gevolgd door de categorie mensen met chronische psychogene rugklach ten (25\%: Bruinsma, 1987).

opvallend is dat personen die wegens psychische stoornissen aituallen over het algemeen jonger zijn en beter opgeleid dan de overige arbeidsongeschikten. Daarnast zijn mensen met psychische problemen vaker volledig en langer arbeidsongeschikt dar mensen die tot de andere diagnosegroepen behoren. Bovendien blijken uiteindelijk relatief weinig van hen terug te keren in het arbeidsproces (De klerk e.a., 1986; knepper, 1986), wardook er sprake is van een cumulatief effect, van waruit de sterke toename wan 


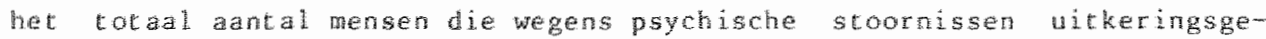
recht igd 2 in kan worden begrepen.

Sude de latste 15 jat is ex weel betenschapel jk onderzok gedaan naar de ooraken en achergronden wan de toename van het antal AAw/Wo-uiteringegerechtigden (Snuliders, 1984b). Ondanks deze vele onderzoeken en publicaties kan er nog steeds geen eenduidige verkining worder gegeven voor de oorzaken wan arbeidsongeschiktheid en woor de omang die deze heeft angenomen (Buys, 1984). Zoals hierwoor reeds is aangegeven, kont de snelste tomame van het a antal arbeidsongeschikten voor rekening van de psychische stoornissen: diagnosecategorie V (De Klerk e.a., 1986 ).

Over de oorzaken wan de coename wan de (lichte) psychische stoornissen als reden van arbeidsongeschiktheid bestan vanut o. a. de sociologische, psychologische en psychiatrische disciplines referentiekaders en theoretjohe paradigma"s verschillende hypothesen en verklaringen lo.a. Philipsen, 1969; Giel, 1976, Wiersma, 1980; De Jong, 1984; Schellart, 1987).

Wegens het feit dat er op macro, meso- en microniveau meerdere oorzaken voor ziekteverzuim en arbeidsongeschiktheid an de orde kunnen zijn, 1 igt een multicausal werklaringsmade voor de hand.

Wolgens het eindvers lag van de commissie 'Bestudering Ontwikel ing Ziekteverzuim' (Mertens en Strengy 1981) kunmen de factoren welke voor de verklaring van het toenemend ziekteverzuim en het toenemend aant arbeidsongeschikten wegens psychische stoornissen van belang zijn, in de volgende drie categorieên worden verdeeld:

- maatschappel ijke en bedrijfstructurele ontwikkelingen;

- iatrogene effecten;

- wpecifieke psychologische persoonskenmerken.

In de volgende peragrafen worden deze drie verklaringscategoriežn op basis van literaturstudie mader ge inventariseerd.

\subsection{ARBEIDSONGESCHIKTHEID ONDER INULOED VAN MAATSCHAPPELIJKE EN BEDRTJFSSTRUCTURELE ONTWTKKELINGEN}

lln de loop der tijd zijner vanut matschappelijke en bedrijtsstructurele 
ontwikklingen meerdere verklaringen gegeven voor het tomenend aambl mensen dat wegens psychische problemen niet (meer) kan werken. Samengevat komen de verklaringen erop neer dat enerzijds one moderne maatschappij de mensen psychisch ziek en daarnee arbeidsongeschikt makt, terwijl anderzijds steeds meer mensen in geestelijke problemen komen door de aard wan het hedendagse werk en de slechte werkomstandigheden.

Zo gaat Aakster (1973) ervan ult, dat verveending in de werksicuate onder invloed van processen van "schalvergroting" en Functieveranderingen, fusies, reorganisaties en tegelijkertijd de onbereikbarheid van immateriele doelen en cem onzeker toekomstperspectief, verantwoordelijk zifn voor stresssymptomen en darmee voor de progressie van het aanal arbeidsongeschikten.

Weyel (1974) verklaart de stijging van het aantal arbeidsongeschikten wegens psychische problemen vanuit een toenemende "sociogene welzijnsmood". Volgens voornoemde auteur heeft de huidige sociale onzekerheid een belangrijke invloed op het ontstaan van klachten en symptomen zoals gevoelens wan gejaagdheid, prikkelbarheid, 'afgeknapt' zijn, nergens meer tegenop kunnen, neiging tot huilen, neerslachtigheid, onzekerheid, verminderde concentratie, gebrek aan eetlust, seksueel disfunctioneren, onredelijke agressiviteit, gevoelens van leegte, angst en depressiviteit.

Deze klachten en symptomen van 'sociale ziekte' worden vollgens weyel (1974) mede veroorzakt door het feit dat degenen die daadwerkelijk lichamelijk ziek zijn, psychosomatisch gestoord of psycho-social deficiënt, wel een witkering krijgen en zo behoed worden tegen verarming, mar regelijkertijd in een sociaal isolement terechtkomen.

Een dergelijk isolement en daardoor ontstane klachten en symptomen laiden tot angststoornissen en kunnen op zich een sochal invaliderend effect hebben (Eijk, 1982).

Welzjjnsnood en daarmee samenlangende angsten komen volgens Ringelberg (1973) woort wit de toegenomen sociale onzekerheid ten gevolge van het conflict dat bij vele mensen is ontstaan vanuit de discrepantie tussem enerzijds de matschappelijke ontwikkeling, gekenmerkt door humanisering van de arbeid en democratisering van de samenleving, en anderzijds do technisch-economische ontwikkeling, die in het bedrijfsleven steeds meer 
gat overheersen en toenemende hoge thal iteitseisen aan mensen stelt.

noor deze ontwkkelingen in de werksfeer is de individuele zelfstandige werker-oude-stij! het meest kwetsbar. "Zonder succes verzet hij zich tegen de dreigende vervreending van $z$ ijn werk en hij vindt onvoldoende compensarie in zijn gezin en wijetijabesteding. Bij invaliditeit of ziekte - al dan niet mede het gevolg van de frustratie - moet hij dan nog de moellijke verandering ondergan van een wereldbeeld, geent op een witdagende vadermatschappij, nat es wereldbeeld, geent op een koescerende moedermatschapij, late als uitvloeisel de zegeningen van de sociale collectieve voorzieningen", aldus Ringelberg (1973).

De cognitieve en emotionele herstructurering die dergelijke veranderende omstandigheden vereisen, kan gepaard gaan met intrapsychische conflicten, welke op zich tot psychische, fysiologische en aanpasingsproblemen kumen Leiden (verkley en spruit, 1983).

ook Giel (1976) zoekt de oorzaak niet zozeer in het toenemen van psychische stoomissen op zich, maar in de toegenomen sociale onzekerheid en eenzatmeid onder de mensen. De daardoor ontstane psychische problemen leiden tot ziekregedrag en somatisering, inclusief vluchten in behandeIing, al of niet in het alternatieve circuit, dan wel in pseudo-religieuze therapeut ische gemeenschappen. Disfunctionerende en in het arbeidsproces minder bruikbare mensen die regulier ziektegedrag vertonen, komen in het kanal. van het sociale zekerheidsstelsel terecht. "Een proces," allus Beek (1977), "dat begrijpelijk is vanuit de economische doelstelling van het arbeidsbestel en mogelijk is vanuit de sociale wetgeving en een utopisch solidariteitsbegrip, warbij de vervuliler niet betalt, omdat er geen directe financiäle terugkoppeling nar de werkgever plaatsuind en betrokkenen de verantwoordelijkheid voor hun verzuimgedrag wordt ontnomen."

Daarbij spelen factoren als een werkgelegenheidstekort, een verschil in vraag en a arbod en met name een gebrek aan passend werk een determinerende rol, In dit verband veronderstellen o.a. Van den Bosch en Petersen (1980) dat het aantal arbeidsongeschikten een afspiegeling is van de ontwikkelin gen op de arbeidsmarkt en derhalve niet alleen wordt bepald door persoonsgebonden arbeidsbeleminerende psychische ziekten of gebreken.

Wiersma (1979) verklaart de oorzack van het toegenomen aantal langdurig. 
arbeidsongeschikten op psychische gronden un de geleidedijk toegenomen stress, waraan men in onze samenlewing met $z$ ijn snel opeenvolgende veranderingen wordt blootgesteld. Industrialisering, autonome technische ontwikkelingen, automatisering, schalvergroting, ontzuiling, nomverandering en individualisering maken volgens hem onze samenleving zodanig complex, dat het individu steeds meer wordt geconfromteerd met gevoelens van onzekerheid, wich witend in psychische en psychosomacische klachten, wardoor men viteindelijk buiten het arbeidsproces kan geraken.

volgens vroege (1982) is in deze kwestie het proces van 'survival of the fittest' in het geding. Ontslagdreiging, toename wan eisen met betrekking tot de produktiviteit en hogere eisen met betrekking tot het werktempo, worden 'betaald" met een toename van zäekteverzuin en arbeidsongeschikeheid. Dit geldt met name in die gevallen waar, mede als gevolg van stare managementstructuren, onvoldoende flexibiliteit in het werk en de werksituatie aanwezig is en te weinig hersteltijd en herstelmogelijkheden worden gegeven om ervoor te zorgen dat de balans tussen belasting en belastbatheid in evenwicht kan bijuen.

Nijhuis (1984) en Smulders (1984) tonen aan hoe arbeidsomstandigheden, bedrijfsstructurele, technologische, specifieke tak- en functiegebonden ontwikkelingen mede een belangrijke rol spelen bij arbeidsongeschikcheid wegens klachten wan 'psychogene aard'. Dit geldt overigens niet alleen voor het vrije bedrijf, maar ook voor de sociale werkplaatsen (Dijkstra, 1977; Wijnen, 1986).

Bijlsma en Koopmans (1982) wijzen erop, dat blijvende arbeidsongeschiktheid bernvloed kan worden vanuit de bedrijven. Daarbij noemen zij manipulatie en op afvloeing gerichte activiteiten, zoals reorganiseren, weranderen van functie-eisen en tijdens het ziekteverutu geen contacten onderhouden met de betrokkenen. Deze bedrijfsmatregelen an het gebrek aan 'social support"' vanuit een afdeling personeelszaken blijken ernstige psychische problemen teweeg te kunnen brengen en tot persisterende arbeidsw ongeschiktheid te kumen leiden (Nijhuis en Soeters, 1982).

Van der Putten (1981) en Buys (1984) verklaren de toename wan ziekteverzuim en arbeidsongeschiktheid om psychische redenen uit de intensivering van de arbeid, met name in het onderwijs, het welzijnswerk, de gezondheids- 
sector en het bankwezen. In deze sectoren mot gandeweg, dikwils ten gevolge wan bezuinigingen, meer mental belastend werk verricht worden door minder mensen, met als gevolg een toename vam psychische belasting en een darmee samenhangende verhoogde kars op psychische en psychosomatische klachter.

Wiet alleen overbelasting, mar ook onderbelasting in de werkituatie en daaran gerelateerde gevoelens van machteloosheid worden als een belangrijke determinant wor ziekte en arbeidsongeschiktheid gesignaleerd (Van Wely, 1983). Onderbelasting kan tevens een gevolg van werkloosheid zijn. Meerdere onderzocken ondersteunen deze veronderstelling, dat 'arbeidsdeprivatie" bij veel mensen aanleiding geeft tot psychische stoornissen (Merens-Rietstra, 1981; Philipsen, 1983; Spruit, 1983; Den Heeten e.a., 1988).

Ziektegedrag in de vorm wan werkverzuim en witheindelijke arbeidsongeschikt heid worden vanuit een circulair causaliteitsmodel, het zogenaamde 'cybernetische model" steeds meer gezien als een gevolg van de te grote discrepantie tussen dragkracht en draglast (Bax, 1984). Met betrekking tot de draagkrachtzijde meldt Bowbly (1979) een vermindering daarvan als gevalg van veranderingen in het opvoedingspatroon en de gezinsomstandigheden in de westerse geindustrialiseerde landen. Aan de draaglastzijde wijst Kompier e.a. (1986) op de algemene verschuiving van fysieke naar steeds hogere mentale eisen in het hedendagse westerse arbeidsproces als mogelijke verklaring voor het toenemend aantal arbeidsongeschikten op psychische en psychosomat ische gronden.

Nast de roegenonen ingewikkeldheid van onze maatschappij, die weel mensen noodzakt voortdurend "op hum tenen te lopen', hebben mensen ook steeds hogere eisen en verwachtinget ten aanien van hun vrijetijdsbesteding, hetgen mede extra psychische belasting teweeg kan brengen en de kans op 'welvartsziekten' vethoogt. De porzaak wan deze ontwikkeling wordt a.a. in een veranderde atbeidsethos gezocht: "mensen zoeken thun zelfontplooiing niet meer alleen in het verrichten van arbeid, maar ook in hun wrije tijd, hetgeen thet doel en het functioneren van de arbeidsongeschiktheidswetten arntast wegens de mate warän psychische overbelasting in de privésituatie 
tot klachten en symptomen leidt, war een gedeeltelijke of gehele witkering tegenover staat. De AW en WA zijn daarmee niet alleen klachten-belonende wetten, mar geven op basis van 'recht op een whkering" ook ruinte woor een 'zinvolle vrijetijdsbesteding", aldus Zweekhorst $(1977)$.

Dararaast geven ziekte, pijn en ongeluk cegelijkertijd recht op verzorging, verpleging, financiêle schadeloostelling en een vermändering, soms zelfs volledige wijstelling, van verplicheingen en verantwoordelijkheden. Wolgens Ten Kroode (1982) heeft dit de preoccupatie met het eigen licham wersterkt, waardoor de pijndrempels zijn verlaagd en de hypochondrie is toegenomen.

Woor zover onze verzorgingstat met har sociale wetgeving en har uitvoeringstructuur van invloed is op de 'ervaren ongezondheid', met alle ziekteverzuimgevolgen van dien, wordt er gesproken van 'lexogene effecten'.

Volgens Giel (1985) verzwakken onze arbeidsongeschiktheidswetten de verplichting om de 'ziekenrol' te verlaten. De ontwikkeling van het toenemend ziekteverzuim en het antal arbeidsongeschikten zou zijns inziens dan ook meer te anaken hebben met veranderingen in de 'bekrachwiging" vanuit de privé- en werkomstandigheden van de ziekenrol dan met veranderingen in het patroon van ziekten.

Schuerman (1980) geeft in zijo theoretische beschouwing over "revalidatie als leerproces" duidelijk an, dat (im)materiele bekrachtigende condities in hoge mate bepalend zijn voor het falen of slagen van de revalidatie. Faien kan in dit verband betekenen dat betrokkene in de ziekenrol blijft en o.a. darom niet terugkeert in het arbeidsproces terwijl wagen betekent dat betrokkene in sociaal en beroepsmatig opzicht zo zelfstandig en adequat mogelijk (weer) functioneert (Lancée, $198 \mathrm{lb}$ ).

Hoe belangwekkend een leer-theoretische functie-analyse van de operante werking van de huidige arbeidsongeschiktheidsregelingen kan zijn, wordt hiermee angegeven. Een dergelijke analyse zou vooral van belang zijn om znzicht te krijgen in de positief bekrachtigende werking van deze regelingen op ziektegedrag, mar valt buicen de context van deze studie.

Samengevat kan worden geconstateerd dat matschappelijke veranderingen in 
onze samenleving en bedrijfsstructurele ontwikelingen gedurende de 1.atute decennia de spanningen in het leven van welen heept doen toenemen. op grond van de met deze spanningen samenhangende klachten en symptomen achten ook steeds meer mensen zich niet in stat on te werken.

Mede tegen de achtergrond van de "medicalisering" (Wellen, 1981) van onze stanenleving worden deze spanningsklachten en symptomen geplatst in het perspectief van gezondheid en ziekte.

In dit verband wijst Scheff (1966) op een verschuiwing in beslisingsregels bij medici, in die zin dat, wanneer geen duidelijke keuze mogelijk is, artsen geneigd zijn on in het belang van betrokkene eerdex de aanwezigheid van een ziekte te verondersteliten dan deze te ontkennen. Het risico lopen om een andoening over het hoofd te zien, kan woor de betrokken arts bovendien negatieve consequenties hebben in de vorm van beroepszaken of een tuchtrechterlijke wervolging.

In her kader van de arbeids(on)geschiktheidsbeoordeling wordt het én en ander volgens Beek (1977) nog eens versterkt door het feit dat het gemakkelijker is om betrokkene op grond van een diagnose arbeidsongeschikt te verklaren dan om aan te geven wat de resterende arbeidswermogens zijn en voor welke beropen betrokkene nog wel geschikt zou kunner worden geacht. Dergelijke ontwikkelingen werken volgens lilich (1975) de zogenaamde 'iatrogene invalidering' in de hand, waardoor onder meer onnodig ziekteverzuim en arbeidsongeschiktheid worden veroorzakt.

\subsection{ARBEIDSONGESCHLTHE DD EN LATROGENE INVALIDERING}

In de relatio die er bestat tussen ziekteverzuim en arbeidsongeschiktheid enerzijds en de gezondheidszorg anderzijds kunnen zogenamde 'iatrogene factoren' een rol spelen en als zodanig op betrokkene een invaliderend eflect hebben.

Het begrip 'iatrogene invalidering' wordt gehanteerd in de betekenis wan het ziek(er) en arbeidsongeschikt(er) worden of voelen, dan wel blijwen als gevolg van foutief, onnodig, vertraagd of niet witgevoerd medisch handelen (Buys, 1984). Dit kan zowel betrekking hebben op de bedrijfs- en verzekeringsgeneeskundige als de curatieve sector van de gezondheidszorg. 
Holthuis (1980) wijst in dit verband op de werhoogde hans van "iatrogene invalidering' door de zogenaamde 'uitsluitingsdiagrostiek'.

Bij klachten die psychisch van oorsprong aijn, wordt wata toch eerst ean (volledig) onderzoek naar mogelijke lichamelijke oorzaken gedam.

Tegelijkertijd is er in geval van (dikwijhs later) geconstateerde psychim sche stoornissen een verhoogde kans op 'iatrogeen verzuim" als gevolg wan het sceeds groter wordende antal verwijzingen binnen de curatieve sector nat de tweede-1in en de (ambulante) geestelijke gezondheidszorg (RIAGG). De dardoor ontstane lange wachtijden kunnen een ziek(er)makend effect hebben (De Groot, 1958; Post, 1985).

Soeters (1983) spreekt in dit verband van "stuurloze perioden" waran noch door de behandelende, noch door de verzekeringsgeneeskundige sector een worm van begeleiding word gegeven.

Wooral bij mensen met psychische stoornissen zouden dergelijke stuurloze ziekteverzuirmerioden aan de orde zijn. Bovendien blijken in de praktijk deze sturloze perioden nogal eens extra verlengd te worden, omdat mensen wolgens de curatieve sector niet in a annerking komen voor psychotherapeutische behandeling, bijvoorbeeld wegens "onbehandelbarheid' en 'gebrek aan motivatie" ook al zijn ex klachten aan de orde die werken onmogelijk maken.

Van Mansveld (e.a., 1975) attendeert daarbij op de onnodige herstelvertraging als gevolg van "de chaotisch aandoende structur van de gezondheidszorg en de sociale wetgeving, watbinnen de curatieve en verzekeringsgeneeskundige instanties onathankelijk van elkaar functioneren, dikwijls van elkar niet wetend wat de ander doet of niet doet." rllich (1975) spreekt in dit verband van 'sociale en structurele iatrogente'.

In het kader van de arbesis(on)geschiktheidsbeoordel ing kan een psychologisch of psychiatrisch expertise-onderzoek op zich een klachten- en symcomen-versterkend effect hebben. Daarbij noet niet uitgesloten worden geacht dat de (dikwijls bedreigende) beslissing van de beoordelaar het functioneren van betrokkene tijdens het onderzoek mede bepalt.

Inhoudelijk kumen verschillende vormen van iatrogene efrecten bij onderzoek naar psychische stoornissen worden anderscheiden:

- iatrogene effecten door bij- en nevenwerkingen wan het onderzoek op zich wegens het feit dat betrokkene door de onderzoeksprocedure en -inhoud 
expliciet met zichzelf, zijn verleden en zijn taekomst wordt geconfronteerd;

- iatrogene effecten door 'te veel." of 'te zwar' onderzoek, waardoor er sprake kan zijn van lichamelijke en/of pycho-enotionele overbelasting met zowel kortdurende als blijvende effecten:

- iatrogene effecten door 'onvoldoende' onderzoek: een bekend fenomeen is dat mensen zich niet au sérieux genomen volen, wanneer er naar hun idee onvoldoende of gen aandacht aan hun klachten wordt besteed of wanneer eer onderzoek naar hun gevoel 'kort' duurt, terwijl er wel een uitspraak over de arbeids(on)geschiktheid wordt gedaar. Eén en ander kan fixatie van betrokkenen op tun klachten in de hand werken (Verhulst, 1974).

Samengevat kan worden gesteld dat iatrogene effecten mede kunnen leiden tot (persistering van) arbeidsongeschiktheid en dat deze effecten in het kader van de arbeidsconlgeschiktheidsbeoordeling zo expliciet mogelijk dienen te worden gemakt. Daabij is het met name van belang om aan te geven welk gewicht er in de oordeelsvorming wordt toegekend a an deze iatrogene processen en de (meestal autonoom verlopende) effecten ervan op de subjectieve ktachtenbelewing en ingeschatte belastbaarheid van betrokkene, rekening houdend met diens psychologische persoonskenterken.

\subsection{ARBEIDSONGESCHIKTHEID EN PSYCHOLOGISCHE PERSOONSKENMERKEN}

Psychologische persoonskemerken kunnen een (medierende) invloed hebben op de intensiteit van de subjectieve klachtembeleving en de ziekte- en afwezigheidscrempel, onathankelijk of dit door derden formeel is gefiatteerd of gesanctioneerd.

Recente onderzoeken richten zich steeds meer op de persoonlijke belastbaarheid en weerbarheid als (mede) bepalende factor bij het zich wel- en onwel bevinden, en van daruit op de relatie tussen psychologische persoonsw kenmerken enerzijds en arbeidsongeschiktheid anderzijds (ormel, 1980; Croot Bluemink e.a., 1982; Smulders, 1984).

De relevantie on op microniveau deze problematiek te benaderen wordt bepald door het feit dat bij elke vorm van verminderde arbeidsgeschiktheid 
het individu degene is die beslist of hij doorgat met werken dan wel aich ziek meldt. Het is imers betrokkene zelf die, al of niet op advies yan anderen, beslist tot afwezigheid wegens ziekte en zich daarom arbeidsongeschikt acht.

Tot nu toe zijn er geen aanwijzingen gevonden voor de toename wan ziekteverzuin en arbeidsongeschiktheid als gevolg van een versiechtering in de gezondheidstoestand van onze bevolking (Hunfeld, 1980; Groothoff, 1986). op grond darvan zijn er redenen om aan te nemen dat de beslissing on ziek te worden of door te werken steeds meer uitwalt ten gunste wan ziek worden. De 'ziekcedrempel' is daamee lager komen te liggen.

Het "omslagpunt." on zich op grond van gepercipieerde klachten ziek te me!den en vervolgens arbeidsongeschikt te (willen) blijven, impliceeve in vele gevallen dat een aantal malen achtereen beslissingen moecen worden genomen. Een dergelijke beslissing is geen uitsluitend rationeel besluit, maar één die mede afhankelijk is van een aancal factoren die de "ruimte" bepalen voor een dergelijke beslissing.

In navolging op De Groot (1958) en Larmers (1964) concludeert Philipsen (1969) in zijn proefschrift dat 'de beslissing' om wel of niet te stoppen met werken wegens klachten niet altijd wordt bepald door de and en de arnst wan de aandoening, maar dat er sprake is van een zekere "beslissingsvrijheid' om wel of niet uit het arbeidsproces te gasn. Nast de matschappelijke en de privé-situatie spellen volgens hem daarbij persoonlijke eigenschappen mede een belangrijke rol. Ziektegedrag in de vorm van afwezigheid op het werk heeft te maken met de mate van 'moeten' (verzuim noodzak), "kunnen" (verzuimgelegenineid) en "willen' (verzuimbehoefte).

Het individu beslist in welke mate de gegeven onstandigheden nas zijn idee een bedreiging women voor zijn gezond bestan. In een araral gevallen zal deze beslissingswijheid nihil zija: de ernst van aandoening als zodanig makt werken onmogelijk. In andere gevallen zal de andoening echter minder dwingend zijn en moet het individu op basis van a.a. de gepercipieerde ernst van de aandoening, de belasting binnen de werksicuatie en de geschatte voor- en nadelen van afwezigheid beslissen tot (blijvend) verzun wegens ziekte of niet.

$B$ ij dit beslissingsproces speelt een veelheid van andere factoren een rol, 
zoals de persoonlijke warden, normen, doeleinden, atitude en eventuele veranderingen darin met betrekking tot het wel of niet werrichen van arbeid.

Ziekteveraim en arbeidsongeschikheid kunen tegen die achtergrond worden beachouwd als een individueel gedragspatroon, warbij in zekere mace bepalde psychologische persoonskenmerken richtinggevend zijn ten aanzien wan de gedragskeuz: ziek thuis blijven en potentieel tot de categorie arbeidsongeschikten behoren versus (door-) werken.

Als psychologische persoonskenmerken wan mensen die zich relatief dikwijls ziek melden en zich arbeidsongeschikt vollen, in tegenstelling tot degenen die dit niet doen, worden door diverse auteurs gesignaleerd:

- gebrek aan ambitie en motivatie (Hinkle en Plummer, 1952);

- gebrek aan aanpassingsvermogen, sociale flexibiliteit en tolerantie (Hinkle en plummer, 1952);

- incroversie (Taylor, 1968; Rakhawy, 1973; Cllark, 1975);

- een negatief zelfbeeld en geringe zelfwaardering (Vroom, 1962; Tau, 1981);

- externe 'locus of control' met betrekking tot de gezondheid CPardine e.a." 1981), samenhangend met apathie en pasiviteit (Wiersma, 1980);

- psycho-enotionele (neurotische) labiliteit, angststoornissen en depressiviteit (Sinha, 1956; Cooper en Payne, 1967; Schmidt, 1967; Howell en Crown, 1971; Clark, 1975);

- somatisering van psychologische conflicten en gevoelens van psychisch onbehagen (Howell en Crown, 1971);

- chronische pijn (Fordyce, 1976; Groemman, 1986);

- psychopathologische en persoonlijkheidsstoornissen (Kaplan en Sadock, 1981; Goldman, 1984; Sanders-Woudstra en De Witte, 1986).

Deze aan de hand van een literaturstudie geìnentariseerde psychologische persoonskenmerken zijn mede bepalend geweest: voor de samenstelling van het psychometrisch instrumentarium, dat in deze studie wordt geëvalueerd op zijn 'objectiverende" watrde voor de psychologische arbeids(on)geschiktheidsdiagnostiek (zie 5.4). 


\section{PSYCHOLOGISCHE ARBE IDS (ON) GESCHIKTHE IDSDTAGNOSTYEK}

\subsection{THEORETISCHE ACHTERGRONDEN}

Een psychologisch onderzoek naar arbeids (on)geschiktheid in het kader van de sociale verzekeringswetgeving is eern onderzoek nar de psychische toem stand van betrokkene met het bijzondere doel een schating te maken, voor heden en toekomst (en in sommige gevallen het verleden) van het ziekte-, invaliditeits- en pensioenrisico, alsmede de geschiktheid tot her verrichten van bepalde arbeid (Winkler Prins, 1961).

In het algemeen geldt dat wordt voldaan aan de wettelijke criteria van arbeidsongeschiktheid wegens psychische stoornissen, wanneer er sprake is van arbeidsbelemmerende psychopathologie (ziekte) en/of persoonlijkheidsstoornissen (gebrek). In geval van arbeidsongeschiktheid kan dit wan tijdelijke of blijvende aard zijn. Beide wormen van arbeidsongeschiktheid kunnen betrekking hebben op alle vookkmende loonverdienende werkzambeden op de vrije arbeidsmarkt, dan wel situationeel gebonden zijn aan bepaalde werkzaameden en/of omstandigheden.

Theoretisch is de psychologische arbeids(on)geschiktheidsdignostiek gericht op het bepalen van de functionele relatie ofwel de verhouding cussen enerzijds de 'werkuitvoeringseisen' wan de beroepen wararan volgens de geldende wetelijke criteria moet worden gerefereerd en anderzijds de individuele psychische belastbarheid en beroepsvardigheden.

Voor een juiste oordeelsvorming is het wan belang dat de belasting, woortkomend uit de 'werkuitvoeringseisen' wan de referentieberoepen en de individuele belastbaarheid van betrokkene als grootheden aodanig worden gedefinieerd, dat eenheden kumen worden gevonden met behulp warvan ge metbaar (De Boorder, 1983) en inzichtelijk zijn.

De verhouding tussen de werkuitvoeringseisen (draglast) en de psychische belastbaarheid em beroepsvaardigheden (dragkracht) kan worden voorgesteld als een balans. Figuur 1 brengt de balans tussen draaglast en dragkracht in beeld.

Aan de draaglastzijde van de balans worden nast de werkuitwoeringseisen ook de privé-omstandigheden aangegeven. De draagkrachtzijde betreft het 
arapasings- en oplossingsvermogen (coping) en de ondersteuning vanuit de omgersing (support).

Mer 11 genten geformuleerd heeft de draagkachtijde betrekking op de zogenamde "verwerkingsmogelijkheden" van het indiwidu (kalsbeek, 1967; Kamphus: 1977; Winnubst, 1981; Kleber, 1982).

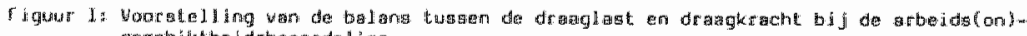

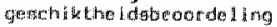

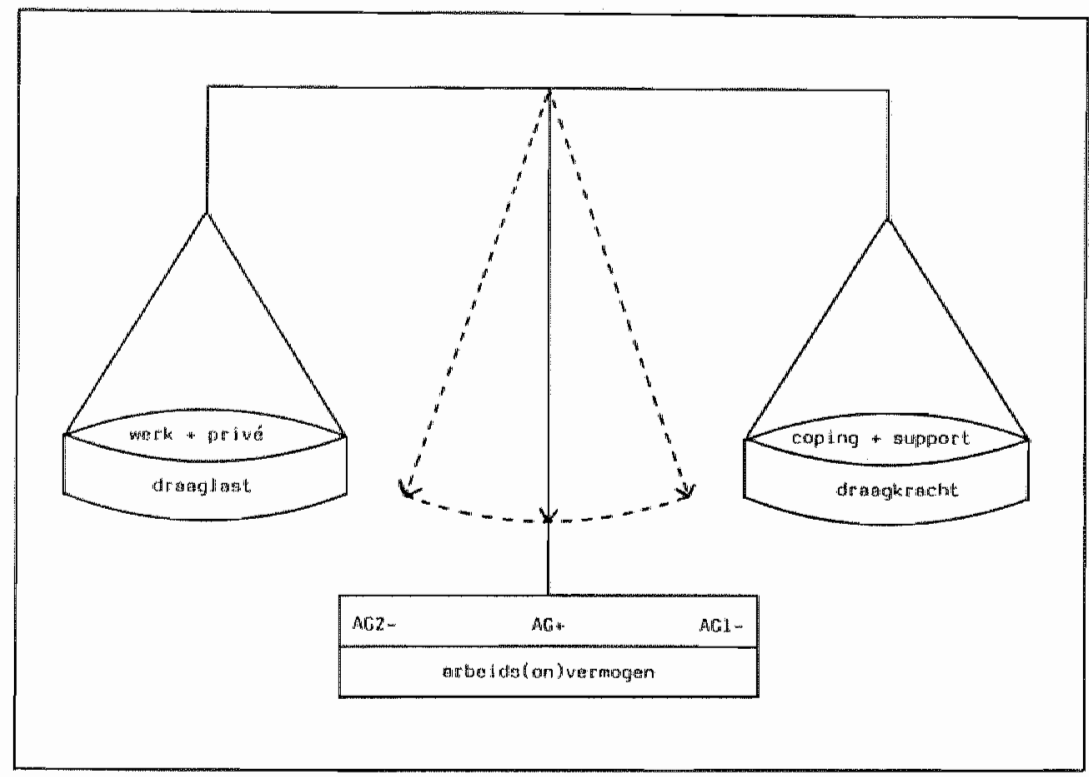

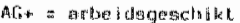

AC;- - orbe ingongenchjot

Het in figuur 1 aangegeven arbeids(om)vermogen kan worden beschoubd als ean resultante van de verhouding tussen draglast en dragkracht en kan worden uitgedrukt in termen van (resterende) psychische belastbaaneid en beroepsward igheden.

Figuur I toont hoe een verstoring van deze balans in twee richtingen het arbeidsvernigen kan beinvloeden en tot arbeidsongeschiktheid (AG-) kan leiden, nanelijk enerzijds cen gevolge van overbelasting (AGl-), anderzijds tien gevolge van onderbelasting ( $A G 2-$ ).

Het gat databijniet on absolute warden, mar om de verhouding tussen draaglast en draagkracht (Frijling-Schreuder, 1970), en bij een te grote 
discrepatie or de mate warin mensen door de darmee samenhangende klachten en symptomen niet in stat zijn om te werken (Bastians, 1977).

Zowel eadogene als exogene factoren kumen een generemende, witlokkende dan wel onderhoudende rol spelen bij het ontstaan van een verstoorde balans tussen draglast en dragkracht, wegens:

- intra- en interpersoonlijke problemen, psychopathologische en persoon1.j.jheidsscoornissen (Schermer, 1970; Panhuis, 1987 ) en/of lichamelijke andoeningen en functiestoornissen (Koten en timmer, in press).

- onvoldoende coping-vermogen (Bandura, 1977), ofwel het niet in stat zijn aan de ongevingseisen en -verwachtinger te voldoen, ondat daarbij de individuele energetische, motorische, cognitieve en emotionele grenzen van belastbartheid (dreigen te) worden overschreden (Van Bastelaer en Van Beers, 1982; Koten, 1985);

- het ontbreken van voldoende ondersteuning (support) door anderen om de persoons- en omgevingsgebonden problemen, eisen en verwachtingen aan te kunnen (Ronme, 1974);

- onvoldoende mogelijkheden on aan de lichamelijke en geestelijke behoeften van het individu tegemoet te komen (Caplan e.a., 1975; Grandjean, (982);

Een te grote en langdurige discrepantie tussen draglast en dragkracht kan bij onvoldoende tussentijdse lichamelijke en psychische ontspanning als pathogene factor leiden tot functiestoornissen en mede leiden tot een vermindering in psychische belastbarheid en beroepsvaardigheden als gevolg van:

- veranderingen in de affectieve functies, zoals angst, vrees, depressie en schuldgevoelens (Cofer en Appley, 1964);

- veranderingen in cognitieve functies, zoals concentratie, geheugen, warnemen, denken en bewustzijn (Kahn, 1970);

- veranderingen in de fysiologische functies, welke berusten op reacties wan het autonome zenuwstelsel en het hormonale systeem (selye, 1976);

- veranderingen in de motorische functies, zoals verhoogde spierspanning en tremoren (Lazarus, 1976);

- veranderingen in gedrag en aanpassingswermogen (Horowitz, 1976).

Hierop aansluitend kunnen voor de psychologische arbeids(ongeschiktheids- 
diagnowiek global drie relevante klassen van arbeidsbelemerende gtoornisen worden onderscheiden: psychische, fysiologische en gedragsmatige (sociale) stoornissen.

Zonder natr volledigheid te streven geven kleber (1982) en Suesan en he iche (1983) de volgende stoornissen ala:

\section{Psychische stoornissen}

ariget, geturiteerdheid, wijandigheid/wrok/moede, verdriet, zich gespanner

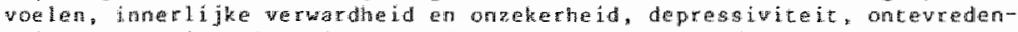

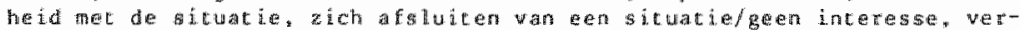

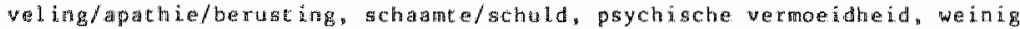
zedrespect. hulpeloosheid, gerfige tolerantie wor anderen, besluiteloos heid, concentratie- en derkatoornissen, vergeetacheigheid, psychoneurotische scootnisgen, psychotitsche stoornissen.

\section{Fysilologische stoornissen}

werhogíng bloeddruk on hartwala, verandering in ddembling, werandering in huldweteramd, verandering in spierspanning, afname spijsvertering, verhogirg bioedsulkerspiegel, hoger gehalte witte en rode bloedlichampjes, hoger gettelta cholesterol en vifje wetzren in thec bloed, verhoging stal-

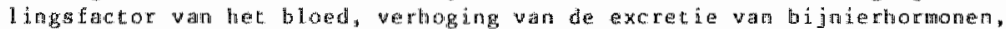
droge mond, transpireren, du zel inger en flausten, vermoeidheid, darmuscornigsten, werandering in lichambgewicht, menstruatie- en pocenciestoornigsen, tanden knarsen, coronaire stoornissen, magzweet, eczeem, hypervent latie, hoofd-, nek- en rugktachen, slipeloosheid.

\section{Gedragsmatige (socialle) stoornissem}

agressief gedrag, rusteloos gedrag, ongecoórdineerd en inefficient gedrag, paniek - en angstig gedtag, het vermüjen wan een situtie, verandering in activiteiten en prestaties, ongelukken (bijwoorbeld op her werk), troken, gebruk van alcohol, Jrugs en/of medicijnen, slaaproblenen, verander ing in ectust, stotieren, bewegingsdrang (tics), wetkverzuin.

Psychische, fysjologische en gedragsmatige stoornisser kunen functioneren als afzonderlijke processen naar aanleiding van een interne of externe gebeurtenis met ejgen specifieke reacties en darmee samenhangende beperkingen. De specificiteit van deze reacties kan volgens olst, Kok en orlebeke (1980) zowel aan de stimulus (stimulus-specificiteit), als ook aan de indjuiduele persoon gebonden $z$ ijn (individuele respons-specificiteitit.

Ten atnzien van deze specificiteit zijn er verschillen tussen personen met betrekking tot:

- de betekenisverlening an de interne of exterme stimuli ('appraisal': Lazarus, 1966); 
- de aard en de vorm van de verwerking ervan ('anticipation'. 'selfmefficacy" en 'coping': Bandura, 1977);

- de gedragskeuze ('locus of control': Andriessen, 1972), hetgeen mede wordt bepald door

- de regelmogelijkheden, vrijheidsgraden en sociale ondersteuning (Ronne, $1974)$.

Tegen de achtergrond wan deze persoonsgebonden specificiteit van verwerkingsmogelijkheden betreft psychologisch onderzaek naar arbeids(on)geschiktheid een andividuele beoordeling van de (resterende) psychische belastbarheid en beroepsvaridigheden.

Bij onderzoek naar de arbeids(on)geschiktheid wordt in de eerste plaats gekeken naar de belasting, voortkomend uit bepalde werkomstandigheden, specifieke taken en eisen (draglast), in relatie tot de belastbaarheid en beroepswaardigheden (draagkracht).

In de werksituatie wordt verwach dat men zich aan de werkomstardigheden aanpast, de taken behorende bij de functie adequat uitvoert en daarbij woldoet aan de darmee verbonden sociale, economische, psychologische, lichamelijke en perceptuele eísen.

Werkbelasting, toekomstonzekerheid, gebrek aan steun en participatie, intrapersoonlijke conflicten, maar ook rolconflicten, voortkomend wit. iemands functie en rolambigutedt als gevolg van onduidelijkheid in de functie-omschrijuing en een gebrek aan een goede afbakening van taken, verplichtingen en verantwoordelijkheden, kunnen als evenzovele "stressoren" werken (Van Vucht Tijssen e.a., 1978).

In ditt verband spreekt Gersons (1987) van 'werkstress', warmee een verzameling van toestanden wordt angeduid, die verbonden ziju aan de warkituathe als oorzakelijk element van owerbelasting. In het algemeen betreft het werkzamheden en werkomstandigheden die evident onredelijk van ard zijn of die van een bepalde persoon zonder twijfel teveel eisen.

Wanneer de aard van de werktaken voor het individu te zwar of te moeil ijk is, wordt gesproken van kwalitatieve overlading, terwijl ar bij teen te grote hoeveetheid van taken en werkzambeden sprake is van kwantibatieve overlading (French en Caplan, 1972). Volgens Kas1 (1978) geeft kwalita tieve overbelasting vooral psychische stoornissen en kwantitatieve overbe- 
lasting fysiologische stoornisgen. Beide vormen van overbelasting kunnen tot stoornissen in het sociale en beroepsmatige functioneren leiden.

Darnast kan ex ook sprake zijn van "onderbelasting" in de werksicuatie. ook een balangverstoring door zogenamde "onderstress" verhoogt de kans op arbeidsbelemmerende klachten en symptomen (Van Wely, 1981).

op indiwiduel niveau is het zeer goed mogelijk dat het werband tussen psychische belasting en ziekteverzuim, aq. arbeidsongeschiktheid, niet Lineair verloopt, maar volgens een U-vormig verband: bij een zeer hoge en zeer geringe psychische belasting is er sprake van een grotere kans op ziekte dan bij een 'normale' psychische belasting (Schellart, 1987). Bij belastingverhoging binnen de grenzen van de draakracht blijft stress de betekenis houden van uitdaging, zogenamde 'eustress". Gaat de belasting daarencegen deze grenzen te boven, dan krijgt deze al gauw een bedreigend karatkter, zogenamde 'disstress' (Bremer, 1983).

ook schijnbar weinig belastende, maar voortdurende monotone en repeterende taken worden in verband gebracht met ziekteverzum (Ministerie van Sociale Zaken en Volksgezondheid, 1954), terwijl eveneens de mechanisering, automatisering en weinig vrijheid of autonomie in het werk als mogelijke oorzaken daarvan worden genoemd (Smulders, 1984b).

Crandjean (1982) wijst in dezen op het fenomeen 'verveling' als psychologisch construct ter verklaring van ziekteverzuim en arbeidsongeschiktheid van mensen:

- die moe zijn;

- die in de nachtdienst werken;

- met een lage motiwatie;

- met een lagg opleidingsniveat, kennis en geschiktheid;

- met een hoog streefniveau, die verlangen nar een meer uitdagende baan.

Uit Grandjeans onderzoek (1982) blijkt dat zowel psychische overbelasting als onderbelasting een stijging van de aamak van adrenaline ('the performance hormone") tot gevolg hebben. De Functionele toestand van verveling gat derhalve samen met hormonale reacties, die de kans op arbeidsbelemmerende klachten en symptomen zouden verhogen.

Tenslotte wordt er bij de psychologische arbeidsongeschiktheidsbeoordeling nagegaan in hoeverre er sprake is (geweest) van problemen in de privé- 
situatie van betrokkene. Psych ische overbelasting in de privésituatie kan name1ijk eveneens tot ziekte en arbeidsongeschiktheid leiden (Boer, werhage en De WolfE, 1983).

Met name kunnen problematische privé-omstandigheden een overbellastend effect hebben, zoals ziekte, financiele zorgen, conflicten, sociaal isom lement en een gebrek an hechte relaties. Hec verlies van belangrijke personen, van werk en van huis kan een extra belasting betekenen (Argyle e.a., 1983).

Kleber e. (1986) geeft overzichtelijk weer, hoe zowel plotselinge eenmalige schokkende gebeurtenissen (ongeluk, naturramp, gijzeling en geweld) als dikwijls langdurige cumulerende traumatische ervaringen (oorlog en concentratiekamp) bij inadequate verwerking tot ernstige emotionele en lichanelijke klacheen kunnen leidem en aanpassingsproblemen geven in het social an beroepsmatig functioneren.

Bij de psychologische arbeids(on)geschiktheidsbeoordeling wordt dus met de beide mogelijke oorzaken van overbelasting, wanuit zowell de werk- als de privésituatie, rekening gehouden.

Vraagstellingen naar iemands arbeids(on)geschiktheid met de coevoeging "privé-onstandigheden buiten beschouwing latend" dienen dan ook als 'inadequat.' te worden beschouwd.

In hoeverre er eventueel sprake is van een blijvende arbeidsongeschiktheid hangt af van de mate warin de effecten van de ballanserstoring een reversibel of irreversibel karakter hebben.

Deze (ir)reversibiliteit is enerzijds afhankelijk van de aard, de ernst en de dur van de over- of onderbelasting en anderzijds van de herstel- en compensatiemogelijkheden. De herstel- en compensatiemogelijkheden hebben a. a. betrekking op het vermogen om actief probleem-oplossende en emotie-regulerende 'coping-strategieën' te kunnen hanteren, eventueel met extane vormen van hulp, behandeling en ondersteuning (Lazans 1976).

Er is sprake van een verhoogde kans op chronisch ziekteverzuim en een blijvende arbeidsongeschiktheid, wanneer er wegens onvoldoende herstel- en/of compensatiemogelijkheden sprake is van irreversibele psychische, fysiolow gische en gedragsmatige veranderingen . 
In geval van irreversbele frecten als gevolg wan onvoldoende herstel- en compensatiemogelijheder, met dientengewolge

- struccurele psychische veranderingen (bijvoorbeeld vermindering in cognit tef-intellectuele capaciteiten),

- structurele fysiologische veranderingen (bijwoorbeld chronische hypertensie) of

- structurele gedrags- en aanpassingsstoornissen (bijvoorbeeld agorafobische stoornissen,

kan er sprake zijn wan een blijvende arbeidsongeschiktheid in algemene zin dan wel woor bepalde werkaameden of omstandigheden.

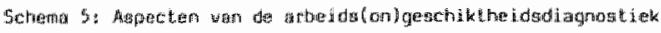

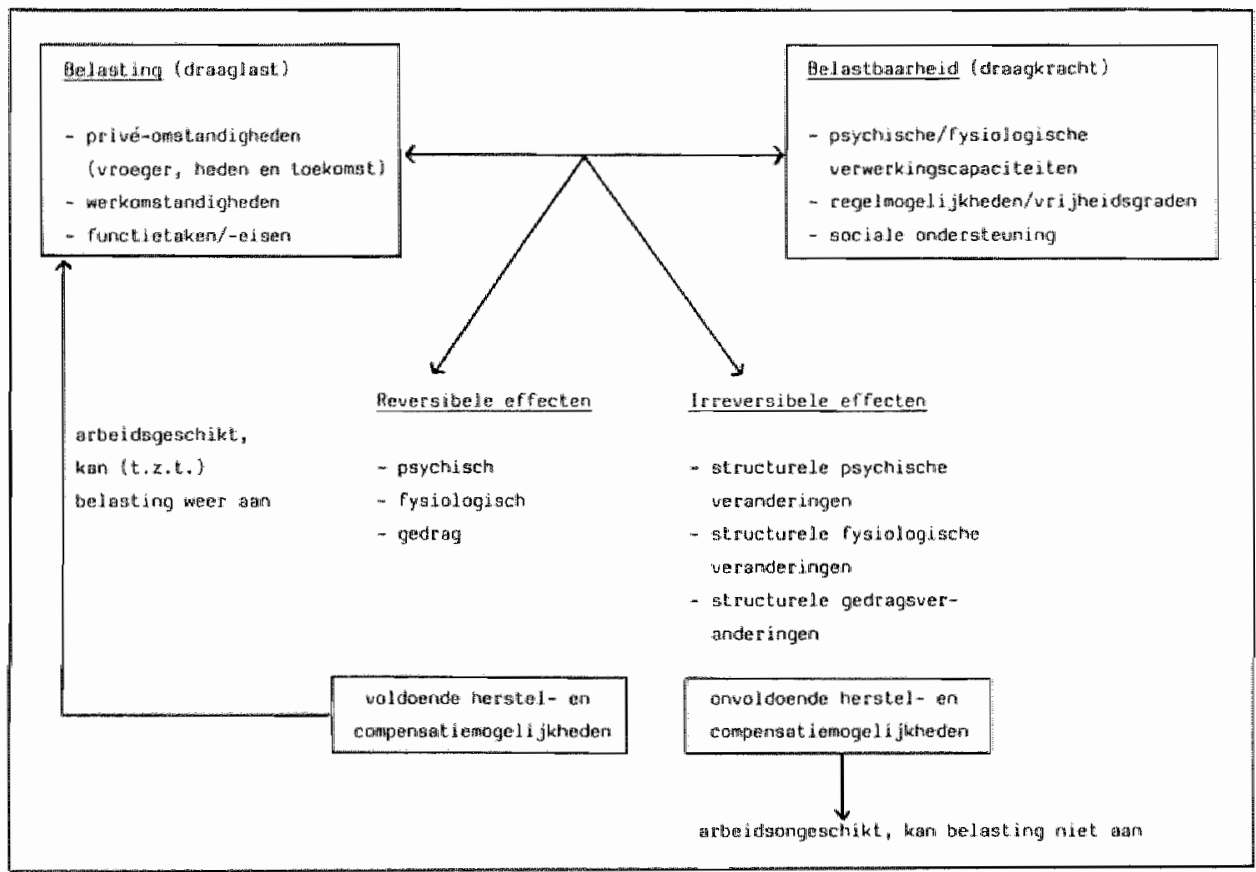

Bovenstand schema 5 geef een overzicht wan de aspecten van de psychologische arbeidsongeschiktheidsdiagnostiek. Deze aspecten vormen de basis van de psychologische oordeelsworming.

Samengevat kan worden gesteld dat de uiteindelijke arbeidsongeschikcheidsbeoordeling afhangt van: 
- de aard van de belasting in relatie tot

- de belastbaarheid,

- de mate warin er na over of onderbelasting voldoende herstel- en compensatiemogelijkheden zijn, ofwel de effecten op psychisch. fysiologisch en gedragsniveau reversibel zijn en

- de mate warin bij onvoldoende herstel- en compensatiemogelijkheden irreversibele effecten gevolgen hebben op structureel psychisch. fysiologisch en gedragsniveau (Lancée, 1988).

Teneinde een zo betrouwbar en doelmatig mogelijke uitspraak te doen over de aard van de beperkingen in belastbatheid en beroepsvardigheden en over eventuele compensatoire mogelijkheden (bijvoorbeeld therapie, scholing e.d.), ter gebele of gedeeltelijke opheffing wan de arbeidsongaschiktheid, is het noodzakelijk dat (ix) reversibele stoornissen, hun determinanten en eventuele herstel- en compensatiemogelijkheden (prognose) op een zo adequat. mogeli jke wijze worden bepaald.

Bij de huidige operationalisering van de arbeidsongeschiktheidsbeoordeling ligt het uitgangspunt niet meer bij de kinische begrippen ziekte er gebrek, maar bij de mogelijk daarmee samenhangende stoornissen en daaruit. voortwloeiende beperkingen in belastbaarheid en beroepsvardigheden.

"Stoornissen in verzekeringsgeneeskundige $z$ in zijn waarneembare uitingen van ziekten en gebreken, die een zodanig nadelig effect uitoefenen op één of meerdere elementen van het verzekerd arbeidsvernogen, dat dit hierdoor afneemt", aldus Timmer (1985).

Nast de lichamelijke belastbarheid kunnen de psychische belastbarrheid en de beroepsvaardigheden worden uitgedrukt in grootheden, die in principe aan de mens te meten zijn: parameters met betrekking tot de destabilisering en/of disregulators in functionele systemen (Lararus, 1966; Meyman en O"Hanlon, 1983; Vrolijk, 1984), tot witing komend in de volgende effecten:

1. Functiestoornissen, waardoor een vermindering in algehele psychische bel astbarheid kan ontstaan;

2. reductie van beroepsvaardigheden, wardoor bepalde taken en werkaamheden mogelijk niet meer kunnen worden uitgevoerd.

Als zodarig zijn de meetbare functiestoornissen en beroepsvarardigheden clan ook de bas is voor de psychische arbeids(on)geschiktheidsdiagnostiek. 
Anders geformuleerd: in het kader van de arbeids(on)geschiktheidsbeoordeling ontuent de diagnostiek wan somatische en psychische functiestoormissen zijn gewicht aan de verklaring die deze stoornissen gewen voor de rede beperkingen in belastubarheid en beroepsvaradigheden.

Deze benaderingswijze sluit an bij de Internatonal classification of Impaiments, Disabilities and Handicaps (TCLDH), welke bij een psychisch ziektebeeld of gebrek onderscheid makt nat soort, duur, ernst en lijdensdruk en wel wat betrett de volgende drie aspecten:

- psychopachologische symptomen/syndromen, respectievelijk persoonlijkheidstoornissen:

- somatische en/af psychische Eunctiestoornissen;

- beperkingen in:

- algemene dagelí jkse lewensactiviteiten (ADL);

- sociale vardigheden;

- beroepsuardigheden;

(World Health Organization, 1980; De Jong e.a., 1983).

Ervan uitgaande dat er geen valide enkelvoudige meetmethoden of psychometrische instrumenten bestan om de psychische belastbararheid en beroepsvardigheden te meten (Meyman en OHanlon, 1983), zal bij psychologisch onderzoek naar arbeids(on)geschiktheid gebruik moeten worden gemaakt van verschillende methoden en instrumenten tegelijkertijd.

Op grond var voornoemde theoretische achtergronden, uitgangspumten en literatuur (zie 3.5) wordt er van uitgegan dat de psychische belastbaarheid en beroepsvardigheden, als samengestelde factor, zich manifesteren in de volgende "meetbare" psychologische persoonskenmerken:

- cognitief-incel lectuele functies;

- kentis en valardigheden;

- karatikerstructuur;

- cmotionaliteit en lichamelijke gevoelens;

- persoonlijke warden, normen, doelen, instelling en motivatie;

- vefinititeiten;

- gedrag en anpassingsvermagen.

De onderzoeksinstrumenten die in het kader van deze studie zijn gehanteerd 
or deze psychologische persoonskenmerken te inventariseren worden beschreven in paragraaf 5.4 .

Hiervolgend word estst nader ingegaan op de indicatiestellingen voor psychologisch onderzoek naar arbeids(on)geschiktheid $(4.2)$ en het protocol dat daarbij kan worden gevolgd $(4,3)$.

\subsection{INDTCATTESTELLINGEN VOOR PSYCHOLOGISCH ONDERZOEK}

Psychologisch onderzoek met betreking tot arbeids(on)geschiktheid is in het bijzonder gericht op het geven van uifsluitsel of betrokkene ten gevolge van ziekte of gebrek qua belastbaaneid en beroepsvardigheden aantoombar al of niet slechter functioneert dan zijn of has leeftijd en beroepsgenoten. Op grond wan kwalitatieve en kwant itatieve gegevens wordt een analyse gemakt van het niveau van (dis-) functioneren van betrokkene.

Psychologisch onderzoek is geindiceerd in geval van:

- psychische pathologie, warbij onduidelijk is welke psychische, fysiologische en gedragstoornissen en daarmee samenhangende beperkingen in belastbaarheid en beroepsvaardigheden aan de orde zijn;

- persoonlijkheidsstoornissen, zoals deze uir de psycho-sociale anamese blijken, zonder dat is vastgesteld welke beperkingen de desberrefende defectcoestanden in de belastbaarheid en beroepsvaardigheden teweegbrengen;

- organisch-cerebrale schade met vermeende veranderingen in gedrab, niveau van intellectueel functioneren, mentale functies (aandacht, concentratie en geheugen), psychomotoriek (stuurkundige varaigheden) en psychisch tempo;

- arbeidsbelemerende klachten, symptomen en stoornissen, samenhangend met over- of onderbelasting in de werk-en/of privésituatie.

In algemene zin kan door middel. van psychologisch onderzoek een gestandaardiseerd en genormeerd beeld worden verkregen van:

- cognitief-intellectuele functies, zijnde intelligentie (het vermogen om allerlei soorten van problemen op te lossen en daarbij gebruik te maken 
var opgedane ervaringen), concentratievermogen, geheugen, begripsvermogen, beoordelingsvermogen, 10 isch denth- en redeneerwermogen;

- kenn is en vardigheden, zijnde de bekwambeden die men zich eigen heefo gemakt door scholing en ervaring, o.a. op administratief, technisch, handvarardig, sociaal en leidinggevend gebied;

- karakterstruetuur, zijnde de eigenschappen, die kenmerkend zijn voor Lemands functioneren, min of meer onathankelijk van de situatie warin iemand zich bewindt;

- enotionaliteit en lichamelijke gevoelens, zijnde de emotionele belevingen en stemingen, watbij kan worden gedacht aan angstgevoelens, stress, depressiviteit, overspantheid, algehele labiliteir, maar ook mogelijk darmee samenhangende lichamelijke sensaties, zoals pijn;

- persoonlijke warden, normen, doelen, instelling en motivatie, zijnde de essentiele uitgangsputen en basis van waruit en warwoor iemand leeft, doet en laat:

- affiniteiten, waronder jemands voorkeur voor bepalde beroepsrichtingen wordt verstan, afgezien van het fejt of hij daarvoor woldoende capaciteiten en mogelijkheden heett;

- gedrag en aampassingsvermogen, betrekking hebbende op hoe iemand warneembar functioneert en in staat is om zich aan te passen aan wisselende omstandigheden.

Afhankelijk van de aard en de inhoud wan de vraagstelling(en) kan er bij psychologisch onderzoek inzake arbeids(on)geschiktheid global het volgende onderscheid worden gemaakt:

- Psychodiagnostisch onderzoek, gericht op de constatering van psychische, psychowysiologische, gedrags- en anpassingsstoornissen en daaruit vootwloeiende beperkingen in psychische belastbarheid en beroepsuardigheden. Het betreft tevens onderzoek naar persoonlijkheidsstoornissen, 'defecten" in de psychische ontwikkeling en mogelijk daarmee samenhangende belemerimgen ten aamien van de geschiktheid voor het kunnen verichten van reguliere arbeid.

Psychodiagnostisch onderzoek is een grensbepalend onderzoek nar belemmerende psychische factoren met betrekking tot de belastbarheid en beroepsvardigheden.

- Psychotechnisch onderzoek, gericht op bepaling van het capaciteiten- 
niveau qua aanleg, persoonshenmerken en igemschapen, leervermogens en specifieke beroepsvaardigheden.

Psychotechnisch onderzoek is als zodanig voorspellend onderzoek betreffende de mate van geschiktheid voor bepaalde werkatuheden.

- Beroepskeuze-onderzoek, gericht op het vaststellen van affiniteiten en rotivatie voor bepalde beroepsrichtingen, functies en werkzamheden en heeft als zodanig een richtingwijzend karakter.

In deze studie staat de evaluatie van 'psychodiagnostisch onderzoek' centraal. Het protocol voor psychologisch onderzoek inzake arbeidscon)geschiktheid en in het bijzonder het protocal voor de psychodiagnostische onderzoeken, zoals die in het kader van deze studie zijn verricht, wordt in de volgende paragraat beschreven.

\subsection{PROTOCOL VOOR PSYCHOLOGISCH ONDERZOEK INZAKE ARBEIDS(ON)GESCHIKTHETD}

Het protocol voor psychologisch onderzoek naar arbeids(on)geschifcheid kent de volgende fasen, welke successievelijk in de tussen harkjes aangegeven paragrafen zullen worden beschreven:

- voorbereiding voor het onderzoek (4.3.1);

- de anamese $(4.3 .2)$;

- het psychometrisch onderzoek (4.3.3);

- het psychologisch beoordelingsproces en adwies (4.3.4);

- nabespreking en rapportage $(4.3 .5)$.

Bij de hiervolgende beschrijuing van deze onderzoekstasen zal tevens worden ingegaan op bepalde beroepsethische aspecten daarvan.

\subsubsection{Voorbereiding voor het onderzoek}

Na binnenkomst wan het schriftelijk verzoek on een bepalide persoon psychologisch te onderzoeken, teneinde en advies wit te brengen ontrent diens arbeids(on)geschiktheid, wordt de betrokken persoon schriftelijk uitgenodigd om op een daarvoor bestemde datum te komen. Deze uittnodiging gaat bij 
voorkeur vergezeld van een informatiefolder over de onderzoeksprocedure en het programa. Een dergelijke folder kan mede zijn bedoeld on betrokkene, voorafgand aan het onderzokk, expliciet bekend te maken met aijn plichten en rechter.

Bij onderoek nar de arbeidscongeschiktheid in het kader wan de uitvoering van de sociale wetgeving of rechtspleging daaromtrent, heeft betrokkene onder meer het recht op kennisneming van de concrete vraagstelling(en) en inzicht in het wetelijk kader warbinnen de onderzoeksgegevens on het daarop gebaseerde advies worden gebruikt.

op grond van de NLP-beroepscode (artikel 2.4 lid 1) wordt betrokkene vooraf mondeling op de hoogte gesteld wan het werloop en de globale inhoud van het onderzoek.

Van tussentijdse wijzigingen in het protocol wan onderzoek wordt betrokkene wan levoren op de hoogte gesteld.

In geval wan een procedure op grand van de Beroepswet is het uitvoeringsorgaan verplicht alle gemakte rapportages van verrichte onderzoeken in het kader van de arbeids(on)geschiktheidsbeoordeling aan de beroepsinstantie ter beschikking te stellen. Het is an de instantie die de opdracht tot psychologisch onderzoek geeft om betrokkene van tevoren op deze verplichting te wijzen.

Het is an de psycholoog die het onderzoek verricht en advies zal uitbrengen betrokkene te wijzen op het bestaan van een klachtrecht en de wijze warop dit recht is geregeld.

Zijnerzijds is betrokkene wettelijk verplicht zich te onderwerpen an een psychologisch onderzoek, dat door één van de wetsuitvoerende instanties ann de betrokken psycholoog is opgedragen. De medewerkingsplicht wordt begrensd door het recht op integritcit, hetgeen onder meer inhoud dat het doel. niek wordt overschreden, dat de middelen adequat en strikt noodzakeLijk zijn en dat het onderzoek niet psychisch schadelijk is.

Deae medewerkingsplicht aan een psychologisch expertise-onderzoek in het kader van de sociale verzekeringswetten berust overigens niet op dwang, mar heeft de strekking van drang. Drogendijk en Rang (1966) spreken in dit verband over 'duldingsplicht': "Inbreuk op de vrijheid van betrokkene kan bij weigering in het kader van de sociale verzekeringswetgeving nooit verder gaan dan een indirecte dwang (= drang)." Dit betekent dat iemand 
niet gedwongen kan worden om een psychologisch onderzoek te ondergan, maar het houdt wel in dat een weigering consequenties kan hebben voor de ulteindelijke beslissing wan de opdrachtgevers.

In de NIP-beroepscode wordt erwan uitgegaan dat indien betrokkene zifo feitelijke medewerking an een onderzoek verleent, hij daarmee ook toem steming voor het onderzoek heeft gegeven (NIP-beroepscode, artikel 3.5).

Volgens de NIP-beroepscode (artikel 3.8) heeft betrokkene overigens in principe te allen tijde het recht on zijn medewerking aan het onderzoek of bepaalde onderzoeksmethoden te weigeren. In de dagelijkse praktijk kan het tot Fricties leiden, dat betrokkene volgens de NTP-beroepscode in principe niet aan door derden opgedragen psychologisch onderzoek hoeft mee te werken, terwijl het weigeren wel wan invloed kan zijn op de beslissing van de opdrachtgever en derhalve voor betrokkene negatieve gevolgen kn hebben.

op de ambivalente rechtspositie van de 'keurling' in het kader van de uitvoering wan de sociale wetgeving en verzekeringsrechtspraak wordt door van plooy (1985) met zijn literatur- en jurisprudentieregister uitgebreid ingegaan.

Met ingang van januari 1988 heeft er een herziending platsgevonden van de beroepscode voor psychologen van het Nederlands Instituut van Psychologen (De Psycholoog, 1987), met betrekking tot o.a. de niet-strafrechtelijke forensische psychologie. Daarin wordt de verticale relatie 'geregeld' tussen enerzijds de te onderzoeken persoon, verwezen door de opdrachtgevers die zich bezighouden met de uitvoering van de sociale wetgeving en de sociale verzekeringsechtspraak, en anderzijds de in dat kader adviserende psycholoog.

\subsubsection{De anamnese}

De anamese is erop gericht een beeld te vormen van voor de waggtelling relevante informatie over iemands levensloop en achtergronden, wan waruit de actuele problematiek kan worden begrepen.

Deze actuele problematiek, waardoor betrokkene mogelijk niet kan werken, wordt vanut een 'multi-conditionele benaderingswijze" (Kruithof, Godaert 
efi Schreurs, 1978) gernventariseerd en geanalyseerd door betrokkene een beschrijuing te laten geven van:

le. de externe of interne gebeurtenstsen) watuoor of watrna de (claim-)Kachten en sympomen zijn ontstaan: de zogenaamde "startconditie".

2e. de wijze watop betrokkene deze startconditie warneemt en interpreteert: de zogenaande "appraisal" (Lazarus, 1966).

3e. de wijze warop betrokkene met deze appraisal omgat, dat wil zeggen acties ondermemt die een verandering van de startconditie ten gevolge kumen hebben: dw zogenaamde "coping' (Lazarus, 1966).

Darbij kan er sprake zijn wan adequate en inadequate coping-stijlen, onder meer afhankelijk wan de 'anticipation', 'self-efficacy' (Bandura, 1977), 'Locus of control" (Andriessen, 1972), regelingsmogelijktheden, wrijheidsgraden en sociale ondersteuning (Romme, 1974).

4e. de emotionele en lichamelijke belevingen en gevoelens in termen wan kachten en symptomen.

5e. de consequenties die deze klachten en symptomen voor betrokkene met zich meebrengen in sociaal en beroepsmatig opzicht, de reacties erop wan de directe omgeving, waaronder ook dievan de curatieve sector (Emanuel, 1986), en de verwachte gevolgen ervan op langere cermijn.

Deze beeldvorming kan vanuit verschillende theoretische verklaringsgron:den, afhankelijk van de factoren die aan de orde zijn, leiden tot de (voorlopige) constatering dat er bij betrokkene sprake is van:

- een 'lnarmonisch evenwicht' tussen de psychische belastbaarheid en beroepsaardigheden in relatie tot de referentieberoepen en functies;

- ees "schijnevenwicht" tussen de psychische belastbaarheid en beroepswat igheden in relatie tot de referentieberoepen en Euncties, wardoor et sprake is vain een verhoogd risico van fysiologische, psychische en mampassingsstcoornisgen, en betrokkene bij daadwerkelijke terugkeer in de refentieberoepen en functies tot schade van zijn gezondheid kar werken;

- Een "gebrek aan wenwicht" tussen de psychische belastbatheid en be roepswardigheden in relatie tot de referentieberoepen en functies, gezien de mate warin er sprake is van fysiologische, psychische en aanpassingsstoonissen (Defares e.

Ten aanzien van de anamese bij psychologisch onderzoek naar arbeids(on)ge- 
schiktheid geldt in het algeneen dat vragen niet verdew nogen gasn dar het doel: het schatten van het ziekteverzuimrisico en het bepalen var de geschiktheid voor het kunen verrichten van arbeid. As adviseur mag de psycholoog daarbij niet verder doordringen in de intimiteit van betrokkene dan nodig is om de voomoemde aspecten wan de arbeids(on)geschiktheid zo adequat mogelijk vast te stellen (NIP-beroepscode, artikel 7.7 ).

De grensbepaling darwan is in de dagelijkse praktijk van de onderzoekende psycholoog overigens een arbitraire angelegenheid wegens het ontbreken van duidelijke criteria en het gegeven, dat dikwijls juist weer persoonlijhe en zelfs intieme ervaringen, belevingen en betekenisverleningen (nede) bepalend zijn voor de te beoordelen psychische belastbarineid en beroepsvardigheden.

Een meer reële grensbepaling ter privacy-bescherming vanult de richt ijinem is, dat betrokkene weet dat de verstrekte informatie en de onderzoeksgegevens niet voor een ander doel mogen worden gebruikt dan voor het gestelde (Leenen, 1980) en dat betrokkene op grond van het inzage- en correctierecht onvolkomenheden in de rapportage kan veranderen en onjuistheden kan laten verwijderen (NIP-beroepscode, artikel $6.5 \mathbb{1}$ id 1 en artikel 7.1 lid 2).

Indien wenselijk en/of noodzakelijk kan met toestemming van betrokkene een 'hetero-anamese" worden afgenomen bijmensen uit zijn of haar directe privé- en/of werksteer, teneinde een zo volledig mogelijk beeld ce krijgen. In dat verband kan er tevens informatie worden ingewonnen van derden uit de behandelende en bedrijfsgeneeskundige sector.

Het is zowel schriftelijk als mondeling (telefonisch) mogelijk om met de behandelende en bedrijfsgeneeskundige sector overleg te plegen, wannepr betrokkene dartoe een schriftelijke machtighn heeft gegeven en de besproken zaken schriftelijk (diefst met datum en tijd van overleg) zijin vastgelegd. Deze schriftelijke notitie makt deel uit wan het dossier en valt daarmee onder het inzage en correctierecht.

\subsubsection{Het psychometrisch onderzoek}

Nast het anamnestisch interview als instrument ter inventarisacie van de 
kwallititeve gegevens voor de pychologische arbeids(on)geschiktheidsbeoordeling, beschik de psycholoog over gestandaardiseerde, genormeerde en gevolideerde psychometrische onderzoksinstrumenten (urenth, 1975; De Zeeuw, 1981; Visser e.a., 1982; Roe, 1983).

Voor de kwantitatieve bepaling wan de psychische belastbarheid en beropsvardigheder, als samengestelde factor bestande uit een aantal psychologische persoonskenmerken, kan van dergelijke geobjectiveerde oriderzoeksinst rumenten gebruik worden gemakt.

We inhoudelijke samenstelling van het psychometrisch onderzok wordt bepaad door de vraagstelling(en) van de opdrachtgevers en de variabelen die in dat werband een classificerende en predict heve warde kunnen hebben.

Teneinde wergelijkbarheid tussen de onderzoekstesultaten en daarop gebaseerde uitspraken van verschillende beoordelaars mogelijk te maken, gaat de woorkeur wit naar een 'standaard onderzoek" dat een meting doet van de psychische belastbaarheid en beroepswardigheder, in termen van:

- cognitief-intellectuele functies;

- keninis en wardigheden;

- karakterstructur ;

- emotionaliteit en lichamelijke gevoelens;

- persoonlijke warden, normen, doelen, instelling en motivatie;

- affiniteiten;

- gedrag en a anpassingsvermogen.

Een dergelijk onderzoek kan, afhankelijk van de anamestische bevindingen en eventuele specifieke vraagstellingen, variabel worden uitgebreid met specifiek onderzoek (bijvoorbeeld neuropsychologisch onderzoek) on bepalale informatio en darop gebaseerde hypothesen te bevestigen dan wel te weer leggen .

Tot heden bestat er echter (nog) geen algeneen geaccepteerd en gehanteerd standard psychometrisch instrumentarium voor de psychologische arbeids(on)geschiktheidsdiagnost iek.

In deze studie wordt daatoe een aanzet gegeven door een in de praktijk toegepast onderzoeksinstrumentarium te evalueren op zijn voorspellende warde voor de classificatie arbeidsgeschikt versus arbeidsongeschikt in geval. Wan psychische problematiek.

Voor de samenscelling van het desbetreffende psychometrische onderzoeksinstrunentatium wordt verwezen nar paragraaf 5 . en bijlage $c$. 
In de hiervolgende subparagraf wordt eerst in het algemeen ingegan op het psychologisch beoordelingsproces en wordt beschreven hoe het arbeidsw (on)geschiktheidsadvies van de psycholoog tot stand komen.

\subsubsection{Het psycholagisch beoordelingsproces en advies}

Bij de psychologische beoordeling var arbeids(on)geschiktheid dienen tegen de achtergrond van de wettelijke criteria voor arbeidsongeschiktheid in het algeneen de volgende vragen te worden beantwoord:

1. In hoeverte berusten de klachten en symptomen op een ziekte of gebrek?

2. In hoeverre is er daadwerkelijk sprake wan arbeidsbelemmerende functiestoornissen?

3. In hoeverre is herstel van de ameidsbelemerende functiestoomissen en daarmee de arbeidsongeschiktheid voor eigen en/of andere in billijkheid op te dragen werkzaamheden mogelijk?

Ter beantwording van deze vragen zijn in dit onderzoek door de beoordalende psycholoog-adviseur de volgende beslispunten gehanteerd:

1. aanwezigheid van klachten en symptomen, die arbeidsbelemerend (kumen) zijn en mogelijk samenhangen met of een gevolg zijn van een ziekte of gebrek;

2. scores op de in dit onderzoek gehanteerde psychometrische schalen die op een geringe psychische belastbaarheid wijzen;

3. discongruentie tussen het niveau van de scores op de tests die beroepsvaardigheden (intelligentieniveau en werktempo) meten en het niveau wan de werkaameden waraan volgens de opdrachtgevers bij de beoordallmg moet worden gerefereerd;

4. de (ir)reversibiliteit van de klachten, symptomen, verminderde psychische belastbarheid en beroepswardigheden, in relatie tot de herstelen compensat iemogeli jkheden.

Voornoemde beslispunten vormen de basis voor de keuzen die de psycholoogadviseur makt tijdens het beoordelingsproces en zijn riche inggevend voor de beslissingen die stapsgewijs in de diagnostische besluitvorming worden gemomen. 


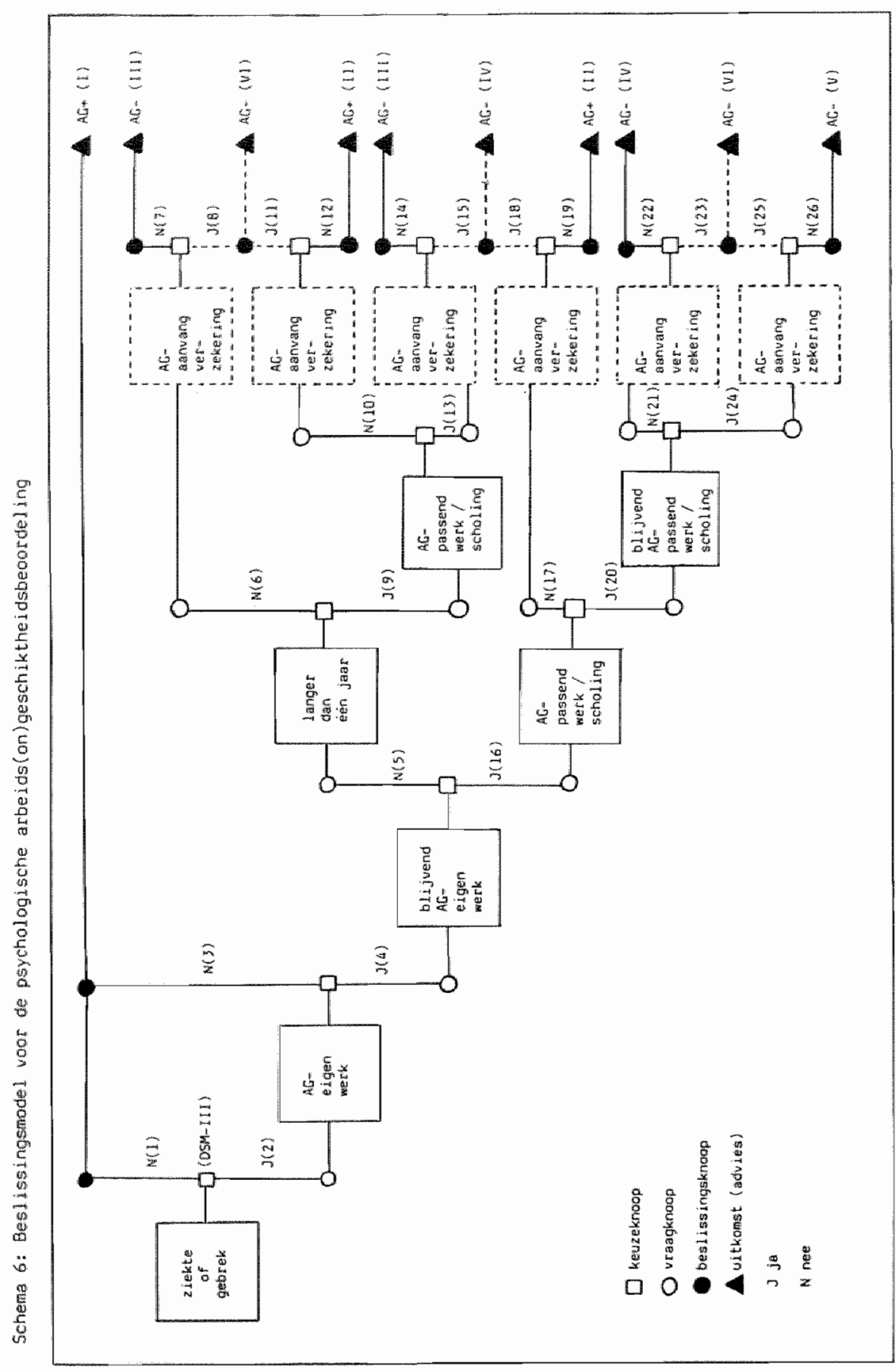


Op basis wan anamestische en psychometrische informatie enerajos en expliciete en impliciete deskundige kennis anderijis neemt de psycholoog-adviseur beslissingen. Derhalve is er sprake van een zogenamad "informeel beslissingsproces" (Roe, 1983), waabij de psycholoog-adviseur op grond van een semi-kinische werkwijze tot voorspellingen komt an wan daaruit redenerend tot belissingen; woorspellen en beslissen vallen als zodanig samen.

Tegelijkertijd wordt er met de regelgevende criteria van de opdrachtgevende (wetsuitvoerende) instantes rekening gehouden, met name me de voorgeschreven volgorde, waarin bepalde vragen moeten worden beantwoord. De volgorde van de vragen wan de opdrachtgeversheeft als zodanig een prescriptief karakter en de beantwoording darvan houdt ifedere keer een beslissing in.

Deze beslissingsmomenten in het beoordelingsproces zijn aan te geven in een model ofwel een zogenaamde "besissingsboom'. Een dergelijke bes 1 is singsboom structureert het beslissingsproces, wardoor het zichtbar wordr en de onderdelen en keuzemogelijkheden ervan expliciteert (vlek, 1987).

Het in deze studie gehanteerde beslissingsmodel voor de psychologische beoordeling van de arbeids(on)geschiktheid is weergegeven in schema 6 .

In dit beslissingsmodel zijn aangegeven:

- de volgorde van denkstappen ( 1 t.e.m. 26);

- de respectievelijke keuzemomenten ( $\square=$ keuzeknoop);

- de keuzemogelijkheden/vraagstelingen ( $\mathrm{O}$ = vraagknoop);

- de beslissingen ( $=$ beslissing);

- de uiteindelijke adviezen $(\Delta=$ advies $)$.

Aansluitend op voornoemde psychotogische beoordelingscriteria en de regelgeving van de advies- en uitwoeringsorganen met betrekking cot de volgonde van de te beantwoorden vragen worden de volgende beslissingsregels gehanteerd.

In de eerste plaats wordt aan de hand van descriptieve gegevens bepaald of er sprake is wan een psychisch ziektebeeld dan wel psychisch gebrek.

Het 'omslagpunt' daarbij is of de klachten, symptomen en stoornissen classificeerbaar zijn volgens de diagnostische criteria van de Diagnostic and Statistical Manual of Mental Disorders, (DSM-ILI-R, American Psychiatric Association, 1987). 
Als deze vraag onthennend wordt beantwoord op grond van de interpretatie van de beschikbare gegewens en er dus geen sprake is van een ziekte of gebret (1), volgt daruit automatisch de besissing dat er niet kan worden gesproken vat arbeidsongeschiktheld in de zin der wet, c.q. dat betrokkene in algmene zin arbeidsgeschikt is $(A G+, T)$.

Indien er wel sprake is wan een psychisch ziektebeeld (2), leidt dit tot de vraag in hoeverre betrokkene op grond van de datmee samenhangende psychische, fysiologische en gedragsmatige stoornissen zodanig beperkt wordc, dat hij of $z i j$ ook daadwerkelijk niet in staat is tot het verrichten van het eigen werk. Het is namelijk mogelijk dat er wel sprake is van symptomen en kenmerken van een psychisch ziektebeeld, maar dat er geen dusdanige beperkingen in belastbararheid en beroepsvaardigheden aan de orde zijn dat betrokkene als arbeidsongeschikt kan worden beschouwd (3). Het besluit is dan 'arbeidsgeschikt voor eigen werk" (AG+, I).

Met behulp van psychometrisch onderzoek kunnen dusdanige beperkingen in bepaalde psychische, fysiologische en gedragsmatige functiegebieden worden geconstateerd, dat betrokkene - althans actueel - niet geschikt blijkt voor het eigen werk (4). Hierbij vindt een afweging platis tussen de anderzoeksbevindingen en interpretaties daarvan, in relatie tot de desbetreffende werkzaamheden, taken en functie-eisen, waaran volgens de opdrachtgevers moet worden gerefiereerd.

Indien betrokkene als ongeschikt wordt beschouwd voor zijn eigen werk, rijst de vraag in hoeverre hij voor dit werk blijvend ongeschikt is. Zo nee (5), dan kan de vraag gesteld worden of de arbeidsongeschiktheid naar al le warschijnlijkheid langer duurt dan én jaar.

ook kan op verzoek van de opdrachtgever de vraag moeten worden beantwoord in hoeverre er reeds bij anvang van de verzekering sprake was van een gehele of gedeeltelijke (woorspelbare) arbeidsongeschiktheid (6). Zo mee (7), dan is er sprake van voorlopige arbeidsongeschiktheid ( $\mathrm{G}_{-}-$, ITI). Wanneer er wel sprake is van een reeds coen bestaande of voorspelbare arbeidsongeschiktheid (8), kan één van de risicodekkende artikelen, de zogenaamde 'uitsluitingsartikelen', aan de orde zijn ( $A G-$, VI).

Indien kan worden verwacht dat de arbeidsongeschiktheidsperiode voor het eigen werk wel langer dan één jaar duurt (9), kont de vraag aan de orde of betrokkene ook minstens gedurende een vergelijkbare periode arbeidsonge- 
schikt zal zijn voor ander passend werk en in hoeverre scholing cor verkorting van de arbeidsongeschiktheidsperiode, $c$. . ophefing van de arbeidson geschiktheid kan leiden. Is dit niet het geval (10), dan rijst opnieuw de vraag of eventueel één van de uitsluitingsattikelen van toepassing kan zijn. 20 ja (11), dan is het advies 'reeds bij anvang der vergekering geheel, gedeeltelijk of voorspelbaar arbeidsongeschilk' (AG-, VI). Zijn er geen uitsluitingsartikelen van toepassing (12), dan wordt het advies 'geschikt woor ander passend werk, eventueel met scholing" (AGt, II).

Wanneer betrokkene ongeschikt is voor passend werk (13), kan wederom de vraag zich voordoen of mogelijk én der witsluitingsartikelen war towpassing kan zijn. Zo nee $(14)$, dan is er sprake van voorlopige arbeids ongeschiktheid ( $A G^{-}$, III). 20 ja (15), dan is de adviescategorie 'reeds ongeschikt bj aanvang der verzekering' (AG-, VI) aan de orde.

Wanneer betrokkene als blijvend ongeschikt voor eigen werk wordt beschoumd (16) wegens het irreversibele karakter van de beperkingen in de belastbanheid en beroepsvaardigheden, moet de vraag worden beantwoord in hoeverre betrokkene eventueel ook ongeschikt is voor ander passend werk. zo nee (17), dan kan de vraag aan de orde zijn of één van de uicsluitingsartikelen toegepast kan worden. Wanneer dit het geval is $(18)$, dan is het advies 'reeds ongeschikt bij aanvang der verzekering' (AG-, VI). Tndien de toepassing van één der vitsluitingsartikelen niet aan de orde is, dan wordt er geadviseerd "geschikt voor ander passend werk, eventueel met scholing." (19).

Ingeval betrokkene arbeidsongeschikt wordt beschouwd voor ander passend werk (20), dan komt de vraag an de orde in hoeverre dit ook van blijvende aard is en in hoeverre scholing hier iets aan zou kunnen veranderen. Als dit niet het geval is (2l), dan volgt mogelijk de vrab in hoeverre er reeds bij anvang van de verzekering sprake was wan gehele, gedeeltelijke of voorspelbare arbeidsongeschiktheid.

Wanneer voorspelbare arbeidsongeschiktheid niet an de orde is $(22)$, word: er geadwiseerd 'blijuend ongeschikt voor ejgen werk, voorlopig ongeschikt woor ander passend werk' (AG-, IV). Is er wel mogelijk sprake wan arbeidsongeschiktheid bij aanvang der verzekering (23), dan wordt als zodanig geadviseerd $(A G-, V I)$. 
Wanneer tenslote betrokkene ook blijvend ongeschike wordt beschouwd voor ander passend werk (24) en én der uitsluitingsartikelen van toepassing kan zijn (25), dan wordt er als zodanig geadviseerd (AG-, WI). Indien dil niet aan de orde is (26), dan wordt een blijuende arbeidsongeschikeheid voor eigen en ander werk geadyiseerd ( $\left.\mathrm{AG}^{-}-\mathrm{V}\right)$.

Op basis van de toepassing van voorstande beslissingsregels zijn de adviescategorieen I tot en met VI van dit onderzoek tot stand gekomen, nameli.jk:

1. geschik woor eigen werk en/or vergelijkbare werkzaameden;

Il. blijvend ongeschikt voor eigen en/of vergelijkbare werkzamheden, wel geschikt voor andere passende werkambeden, eventueel na scholing;

III. voorlopig ongeschikt voor alle werkzamheden;

IV. blijvend ongeschikt voor eigen enfof vergelijkbare werkzamheden, voorlopig ongeschikt voor andere passende werkzamheden;

v. blijuend ongeschikt voor eigen en/of vergelijkbare werkzamheden en ook blijvend ongeschikt voor andere werkzameden;

VI. reeds geheel, gedeeltelijk of woorspelbar (blijuend) arbeidsongeschikt bij aanvang der verzekering:

- geheel arbeidsongeschikt (artikelen: 44-la-le $\mathrm{ZW} ; 21-1 \mathrm{a} * 21-2 \mathrm{~b}$ AAW; 30-1 a WAO; F (4-1a ABP-wet);

- gedeelteljjk arbeidsongeschik (artikelen: 5-II AAW; 18-II WAO; [F-3 (ABP-wet);

- voorspelbaar arbeidsongeschikt binnen een half jaar na aanang der verzekering (artikelen: 44-1a-2e $2 W ; 21-1 \mathrm{c}+21-1 \mathrm{~d}$ AAW, 30-lb WAO; $F(4-1 b+14-2 A B P-w e t)$.

Op het psychologisch advies als criterium-variabele in deze studie wordt nader ingegaan in paragraaf 5.5.

\subsubsection{Nabespreking en rapportage}

Betrokkene heeft het: recht op het, met tekst en uitleg, mondeling vernemen van de onderzoeksbevindingen en van het advies dat aan de opdrachtgever wordt witgebracht (NLP-beroepscode, artikel 6.7). 
De ervaring in de dagelijkse praktijk leert dat het bespreken van de psychologische onderzoeksbevindingen en het advies in het algeneen op prijs wordt gesteld.

De rabespreking is een aparte dimensie van het expertise-ondersoek, ondat daarin niet alleen andacht kan worden besceed an het eventueel resterende arbeidsvermogen, mar ook aan de herstel- en compensatienogelijkheden van het potentielle arbeidsvermogen. "Dit voorkomt negatieve rixaties en benadruke de eigen verantwoordelijkheid van de betrokkeren", aldus knepper en Den Ouden (1988).

De (afwijkende) mening omtrent de conclusies en het advies van betrokkere kan separat in de rapportage worden opgenomen, al heeft hij of zij ook het recht om zijn of has mening over het psychologisch onderzoek en het advies rechtstreeks en zelfstandig aan de opdrachtgever kenbaar te maken (NIP-beroepscode, artikel 7.8 lid 2$)$.

Wegens het sociaal-wetelijke en administratief-rechtelijke referentiekader warbinmen het psychologisch advies wordt uitgebracht aan daartoe bij de wet gerechtigde instanties en het teit dat de rapportage als zodanig als ondersteuning van een wetsgeldige beslissing van deze instantie geldt, kan betrokkene een verstrekking van de rapportage aan de opdrachtgever niet blokkeren (NIP-beroepscode artikel 7.6 1id 2).

Het is overigens beroepsethisch ontoelatbaar dat vertrouwelijk ingewonnen gegevens van betrokkene ter kennisneming wordt gegegeven aan de opdrachtgever, wanneer deze irrelevant zijn voor het beantwoorden van diens vraagstelling(en). Volgens de huidige jurisprudentie is het dan ook onjuist om in keuringssituaties an opdrachtgevers meer mee te delen dan de onderzoksbevindingen en de conclusie als antwoord op de gestelde wragen (Hubben, 1987).

De psycholoog is niet verplicht een afschrift van de rapportage, die voor de wetsuitwoerende opdrachtgevers bestemd is, aan betrokkene te verstrekken (NIP-beroepscode, artike1 7.5).

De schriftelijke verslaglegging van het onderzoek en het advies mag als "medisch geheim" alleen aan een arts, psycholong. jurist of een dactoe door de wet angewezen instantie, zoals de (Centrale) Raad var Beroep en het Ambteratengerecht, worden verzonden. 
Gezien het feit dat de rapportage meestal voor niet-psychodiagnostisch geschoolde mensen is bedoeld, dient de verslaglegging inzichtelijk en begrijpelijk te zijn, zonder concessies te doen an het wetenschappelijk katakter van de daraan ten grondslag liggende gegevens en de daarop gebaseerde wicspraken en adviezen.

Het ABP kent sinds 17-9-1982 het zogenaamde 'inzagerecht" van betrokkenen met betrekking tot hun gegevensbestanden. Op $28-8-1985$ is daar het 'correctierecht' aan toegevoegd.

De bedrjifswerenigingen, het GAk en de GMD kennen sinds $1-1-1986$ het inzage- en correctierecht.

Betrokkenen thebben op grond darvan het recht op werbetering, aanvuling en verwjdering van gegevens in de rapportage, indien kan worden aangetoond dat de opgenomen gegevens onjuist of onvolledig zijn, of gezien de vrag- en doelstellingen niet ter zake doende zijn (NIP-beroepscode, artikel 7.8 lid 1$)$.

Volgens de herziene versie van de NIP-beroepscode (1987) hebben betrokkenen recht op inzage in de psychologische rapportage, ook wanneer deze voor een wetsuitvoerende instantie is bedoeld (NIP-beroepscode, artikel 6.5 lid 1).

Ongevraagde inzage is niet altijd an te bevelen wegens het risico dat kennisneming wan de onderzoeksbevindingen tot schade van de gezondheid van betrokkene kan zijn (NIP-beroepscode, artikel $7.2 b$ ), dan wel een negatief effect kan hebben op de (psychotherapeutische) behandeling. Dit latste wordt wei de 'therapeutische exceptie' op de desbetreffende beroepscoderegel genoend.

Wanneer inzage in de rapportage als zodanig kennelijk een ernstig nadeel voor betrokkene zelf kan geven, mag volgens de huidige wetscoepasing de psycholoog inzage weigeren. In dat geval heeft wel een door betrokkene aan te wijzen vertrouwenspersoon (psycholoog, arts of jurist) recht op inzage (NLP-beroepscode, artikel 6.51 id 2 ).

Volgens de uitspraak van het Gerechtshof te Amsterdam op 9 juli 1987 is het inzagerecht van vertrouwenspersonen een eigen en zelfstandig geregeld recht (Bron: Medisch Contact, 2 aktober 1987). Dit betreft onder meer dat 
de

vertrouwenspersoon

al leen

over ter

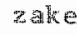

doende informatie met betrokkene mag spreken.

Indien betrokkene geen vertrouwenspersoon wil inschakelen en ondanks een negatief advies in dezen toch inzage in de rapportage wenst, krijgt betrokkene uiteindelijk het recht op inzage volgens het huidige voorontwerp van de zogenande "Patientenwet".

Volgens de bovengenoende uitsprak van het Amsterdams Gerechtshof (juli. 1987) zullen in een dergelijk geval betrokkene, eventueel de behandelaars, maar in ieder geval de "keurend beoordelaar' de gevolgen van de informate hebben te aanvaarden. Daarbij dient de nodige opvang en begeleiding te worden angeboden bij de verwerking van de inzage.

Het hoofdbestur van de Koninklijke Nederlandsche Maatschappij tot Bevordering der Geneeskunst heeft zich in algemene zin uitgesproken voor een 'ongeclausuleerd' inzagerecht (Cense, 1987), doch dit is recentelijke door de algemene ledenvergadering verworpen.

op grond wan artikel \|\| 1 id 4 van de Beroepswet kan de rechter in het belang wan de geestelijke of lichamelijke gezondheid van de betrokken persoon, al dan niet op verzoek van het desbetreffende uitvoerjugsorgaan, bepalen dat het inzien van geneeskundige rapporten niet wordt toegestaan aan een bepaalde betrokkene persoonlijk, maar uitsluitend aan een gemachtigde, die hetzij arts, hetzij advocaat of procureur is, dan wel wan de rechter bijzondere toesteming heeft verkregen.

Ter afsluiting van dit hoofdstuk wordt in schema 7 het rapportagemodel weergegeven, dat voor de verslaglegging van psychologisch onderzoek inzake arbeids(on)geschiktheid kan worden gehanteerd en als zodanig is toegepast. bij de onderzoekspopulatie van deze studie. Dit rapportagemodel kan cegelijkertijd als een algemene leidraad voor de structur, unhoud en uitwoering van het desbetreffende psychologisch onderzoek worden gebruikt. voor een witgebreide beschrijwing van dit model. wordt verwezen naar kabela en Lancée (1988). 


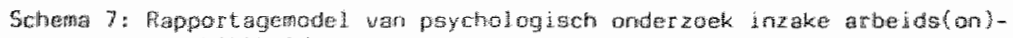
geteris the id

1. Reden war abmeldimg en vaagstelling

2. Personalia

3. Arathesti ische gegevens:

3.1 Kluchtenbescheijuing en ziekteverschijuselen

3.2 Specifiture (medische) aramneme

3.3 ractus anamest

3.4. Familiahe ziektobelden

3.5 Frallitalife anamege

3.6 Blograflsche armannese

3.7 oplelding

3.8 Arbelusinutarisatie

3.9 Militaire dienst

3.10 Psychaseksuele orbwikkeling en huidige gezinssituatie

3. Il Woont i. tuat ie

3. 12 Codsdienst enr leverisbeschousing

3.13 Wijetijdabesteding. dagulling en sociale contacten

3.14 Politiente justitiele contacten

3.15 Persoonlijke crisis en life-events

4. Zelfoeschrijuing en toekomstvisie

5. Algemene klintsche indruk

6. Paychometrisch onderzaek

6.1 Cognitief-intel lectuele runcties

6.2 Kennis en vaurdigheden

6.3 Karakterstructur

6.4 Emotionaliteit en lichamelijke gevoelens

6.5 Persoonlijke warden, normen, doelem, instelling en motiwatie

6.6 Affiniteiten

6.7 Gedrag en wanpassingsvertiogen

7. Hetero-anamerase

8. Ower los behandelende sector

9. Sameruat ing, beschoulwh en conclusie

10. Oiagnose volgens OSM IIII

11. Mdvi.es

12. Magesprek

13. lintage

14. Bi jli age $(n)$ 


\section{HEF ONDERZOEK : OPZET RN UTTVOERING}

In dit hoofdstuk wordt de probleemstelling van het onderzoek van deze studie nader gespecificeerd $(5.1)$ en in concrete onderzoeksvagen witgewerkt (5.2).

In paragraf 5.3 worden de vorm en structur van het onderzoek beschrewen. Paragraaf 5.4 geeft een overzicht van de psychonetrische onderaeksinstrumenten, die in dezen worden geëvalueerd op hum warde voor de psychologische arbeidsongeschiktheidsdiagnostiek. In paragraaf 5.5 stan de verklarende variabelen, die door de respectievelijke psychonetrische instrumenten worden gemeten, en de criterium-variabele schenatisch weergegeven.

De beschrijving van de onderzoekspopulatie wordt in paragraaf 5.6 beschreven en een specificatie var de wijze van data-verzameling (5.7) besiuit dit hoofdstuk.

\section{I SPECTF TCERING VAN DE PROBLEEMSTELLING}

De probleemstelling van dit onderzoek heert betrekking op het bepalen van de voorspellende warde van specifieke psychometrische onderzoeksgegevens in het kader van de psychologische arbeids(on) geschiktheidsdiagnostiek.

De psychologische pordeelsvorming wordt statistisch geanalyseerd en geexpliciteerd aan de hand van beschikbare psychometrische gegevens.

Het gat daarbij on wast te stellen hoe de psycholoog-adviseur de psychomem trische gegevens warower hij beschikt, combineert tot een oordeel inzake de arbeido (ongeschiktheid van de onderzoekspopulatie. Daarioe vind een statistische modelvorming plats buiten de impliciete en expliciate cognitieve representaties van de psycholoog-adviseur om.

Met statistische technieken wordt gezocht nat de formule, die het beste de psychologische arbeids(on)geschiktheidsclassificaties wit de psychometrische gegevens verklaart c.q. woorspelt. Een dergelijke statistische modelvorming impliceert een reductie van een complex beslissings- en beoardelingsproces. Het desbetreffende statistische model geeft aan, welke variabelen bij de psychologische arbeids(on) geschiktheidsbeoordeling zijn 
gebrukt en welke gewichten an elk wan de gebraikte variabelen aijn gegewen.

Omdat het bij deze werkwijze onduidelijk is of het statistische model een goede beschrijuing geeft van hec proces van afwegen en combineren dat de peycholoog adwiseur in werkeli ikheid heeft gevolgd, is er sprake wan een "paramorfe representatie" wan het beslissingsmodel (Roe, 1983). A1s zodanig ressortert deze scudie onder de zogenaamde "paramorfe oondeelstudies" (Hoffitrain, 1960$)$.

In de parmorfe representatie-studies wordt gebruikt gemakt van regressieFormules (Westmeyer, 1976; Knippenberg en Sjero, 1980).

De opzet daarvan bij de psychologische arbeids(on)geschiktheidsdiagnostiek i. als volgt.

De psycholoogadviseur beschikt over cen aantal psychometrische gegevens van de te beoordelen betrokkene. Mede op grond van deze gegevens, maar zonder formules of wegingsvoorschriften, kont de psycholoog-adviseur tot een oordeel ower de arbeidscon)geschiktheid van betrokkene en doet daaromtrent een uitspraak in termen van eem advies. Dit advies kan worden beschouwd als een beslissing.

E* wordt een regressieformule opgesteld op bas is van de beschikbare verklarende variabelen als mogelijke predictoren, warmee de beslissingen (psychologische adviezen) zo goed mogelijk worden voorspeld.

Lineaite regressieformules blijken een goede statistische benadering van beslissingen te geven, warbij de gevonden 'regressiegewichten' de mate aangeven, warin de psycholoog adviseur belang heeft gehecht aan de verklarende variabelen bij zijn oordeelsworning (Roe, 1983). In dat verband wordt ook wel gesproken wan "policy-capturing" (Koele, 1987), "betrekking hebbende op: het statistisch analyseren van informatie-verwerkend en beslissingsgadrag wan de psycholoog-adviseur, met als doel te ontdekken hoe deze de beschikbare psychometrische gegevens heeft gebruikt om cot een arbeids (on)geschiktheidsbeoordeting (voorspelling) te komen.

Het onderzoek is zodanig opgezet dat e kan worden gezocht mar de relatie tussen de desbetreffende psychometrische onderzoeksbevindingen van bepaalde psychologische persoonskemerken als "verklarende variabelen", 
afzonderlijk en in combinatie, en de mede datop gebaseerde psychologische arbeids(on)geschiktheidsclassificatie als "criterium-variabele".

Darmee kan inzicht worden verkregen in de mate warin bepalde meetbare psychologische persoonskentherken de onderscheiden groepen van arbeidsgeschikten en arbeidsongeschikten adequat weten te voorspellen.

De centrale vaag daabij is hoe variantie in de criterium-vandabele cerug te voeren is op variantie in (combinaties van) de verklarende variabelen (predictoren). De criterium-varibele is de psychologische arbeids(ongeschiktheidsclassificarie (adviezen).

In verband met de bepaling wan de instrumentele utiliteit van de desbetreffende psychometrische onderzoeksgegevens wordt nagegan h hoeverre de mede daarop gebaseerde psychologische adviezen daadwerkelijk door de opdrachtgevers zijn overgenomen. Daabij wordt levens onderzocht in hoewerre betrokkenen wel of niet tegen de nede op de psychologische adviezen gebaseerde "voor beroep vatbare beslissingen' van de opdrachegevers in beroep zijn gegaan en wat daaromtrent het rechterlijk oordet wan de desbetreffende beroepsinstanties is geweest.

Aan de hand van deze 'afgeleide' criterium-variabelen kan de doeltrellendheid van bepalde neetbare psychologische persoonskenmerken in breder verband worden aangetoond wat betreft het voorspellend vermogen cen aanzien van:

- de beslissingen van de opdrachtgevers;

- de beslissingen van betrokkenen met betrekking tot het wel of niet in beroep gaan;

- de beslissingen van de beroepsinstanties wat betreft het wel of niet gegrond verklaren van aangetekende beroepen.

Op grond wan de gevonden predictieve waten van de desbetreffonde meet bare psychologische persoonskentrken met betrekking rot de witeindelifke arbeids (on) geschiktheidsbeoordeling kunnen:

le. (woorlopige) beslissingsregels worden geformuleerd, atu de liand waar. wan kan worden beoordeeld of iemand arbeidsgeschikt of -ongeschikt is"

2e. aanbevelingen en voorstellen worden gedaan voor de samenstelling wan een psychometrisch instrumentarium voor de psychologische arbeids(on)geschikthe idsdiagnost iek; 
3e. mogelijkheden worden a angegeven hoe daze onderzoksinstrumenten op hun "voorspellende" warden in de praktijk kunnen worden gereevalueerd en eventuel verbeterd, opdat de psychologische arbeids(on)geschiktheidsbeoordelingen per individuele beoordelaar en tussen beoordelars onderling zo betrowbar en consistent mogelijk worden.

\subsection{OWDERZOERSVRAGEN}

Vanuil de algenene probleenstelling van dit onderzok: 'het nagan van de mate warin op grond wan meetbare psychologische persoonskemerken een voomsplling kan worden gedaan ten aanzien van de classificatie arbeidsgeschikten versus arbeidsongeschikten', kunnen een aantal specifieke onderzoekswragen worden afgeleid.

Deze hebben betrekking op:

- de criterium-variabele, het psychologisch advies: arbeidsgeschikt ( $\mathrm{GG}^{+}$) versus arbeicsongeschikt $\left(\mathrm{AG}^{-}\right)$.

- de afgeleide criterium-variabelen, die inhoud geven aan de 'objectiviteit" van de criteriun-variabele:

- beslissingen van de opdrachtgevers: psychologisch advies wel (ogt) versus niet $\left(O G^{-}\right)$overgenomen;

- beslissingen wan de betrokkenen: wel in beroep (BG+) versus niet in beroep ( $\left.\mathrm{BG}^{-}\right)$gegaan;

- beslissingen van de beroepsinstanties: beroep wel gegrond (GG+) versus niet gegrond (Go-) verklaard.

- de verklarende variabelen, de meetbare psychologische persoonskenmerken en de mate warin deze verschillen bij:

- betrokkenen die door de psycholoogadviseur als arbeidsgeschikt (AG+) versus arbeidsongeschikt ( $A G-$ ) zijn beoordeeld;

- betrokkenen van wie de psychologische arbeids(on)geschiktheidsbeoordelingen wel (OG+) versus niet (OG-) door de opdrachtgevers zijn overgenomen;

- betrokkenen die wel ( $\left.B G^{+}\right)$versus niet ( $\left.B G^{-}\right)$in beroep zijn gegaan; 
- betrokkenen van wie het beroep door de beroepsinstanties gegrond (com) versus ongegrond (GG-) is verklaard.

- de relatie cussen de verklarende variabelen enerzijos en de critceriumvariabele en afgeleide criterium-variabelen anderzijds.

De wragen met betrekking tot de criterium-variabele en afgeleide criterium-variabelen zijn:

1. Melke arbeids(on) geschiktheidsadviezen zijn er door de psycholoog-adviseur an de opdrachtgevers verstrekt ( $A G+$ versus $A G^{-}$)?

2. Welke arbeids(on)geschiktheidsadviezen zijn er van de psycholoog-adviseur door de opdrachlgevers wel en niet overgenomen (oG+ versus oG-)?

3. In hoeverre hebben mede op het psychologisch advies gebaseerde "voor beroep vatbare beslissingen' van de opdrachtgevers wel en niet tot beroepszaken geleid ( $B G+$ versus $\left.B G^{-m}\right)$ ?

4. In hoeverre zijn in het kader van beroepszaken mede op het psychologisch advies gebaseerde 'voor beroep vatbare beslissingen' van de opdrachtgevers door de beroepsinstanties wel en niet gegrond verklaard (GG+ versus GG-)?

De vragen met betrekking tot de verklarende variabelen zijn:

5. In welke meetbare psychologische persoonskenmerken verschillen bet rokkemen die door de psycholoog-adviseur als arbeidsgeschike, respectievelijk arbeidsongeschikt zijn beoordeeld ( $A G+$ versus $A G-$ )?

6. In welke meetbare psychologische persoonskenmerken verschillen betrokkenen van wie de psychologische arbeids(on)geschiktheidsadviezen wel en niet door de opdrachtgevers zijn overgenomen (oG+ versus oG-)?

7. In welke meetbare psychologische persoonskenmerken verschillen betrok- 
kenen die wat en niet in beroep aijn gegan tegen een voor beroep watbare beslissing van de opdrachegevers (BCt versus $B G-$ )?

8. In welke meetbare psychologische persoonskenthen verschillen betrokkenen van wie in het kader wan een beroepsaak het angetekende beroep gegrond, respectievelijk ongegrond is verklaard (GG+ versus GG-)?

De vagen thet betreking tot de relatie tussen de verklarende variabelen (predictoren) enerzijds en de criterium-variabele en de afgelleide variabelen anderzijds zijn:

9. Wut is de predictieve warde van meetbare psychologische persoonskenmerken, afzonderlijk en in combinatie, ten aanzien van de psychologische arbeids(on) geschiktheidsclassificaties?

10. Wat is de predictieve warde van meetbare psychologische persoonskenmerken, afzonderlijk en in combinatie, ten aanzien van de beslissingen van de opdrachtgevers?

11. Wat is de predictieve watede van meetbare psychologische persoonskenmerken, afzonderlijk en in combinatie, ten aanzien van de categorieen betrokkenen die respectievelijk wel en geen beroep aantekenen tegen een voor beroep vatbare beslissing van de opdrachtgevers?

12. Wat is de predictieve warde wan meetbare psychologische persoonskenmerken, afronderlijk en in combinatie, ten aanzen van de categorietn betrokkenen van whe het angetekende beroep door de beroepsinstanties wel, respect jevelijk niet gegrond wordt verklaard?

Het zich bij de beantwoording van voornoemde vragen voordoende methodalogische probleem is, dat de criterium-variabele arbeids(on)geschiktheid arbirrair is wegens het ontbreken van een wetenschappelijke operationele defintie. Het is een voornamelijk op 'expertsmconsensus' gebaseerde criterium-variabele, warbij het ontbreek aan een extern objectief criterium. Externe objectieve toetsing en validering is daardoor niet noge 1 is jk. 
Bovendien is er sprake van een 'verwevenheid" van de psychometrische gegevens en de psychologische adviezen. Van Strien (1986) spreekt in dit verband van 'besmetting' tussen de psychomecrische gegevens an de psychologisch adviezen enerzijds met de beslissingen van respectievalijk de opdrachtgevers, betrokkenen en beroepsinstanties anderzijds. Wegens het retrospectieve karakter van dit veldonderzoek is het niet mogelijk om de psychometrische data en de mede darop gebaseerde psychologische adviezen onafhankelijk van elkar te relateren aan de beslissingen wan opdrachtgevers, betrokkenen en beroepsinstanties.

Deze methodologische "artefacten" geven niet alleen beperkingen in de opzet en uitvoering van dit onderzoek, maar impliceren tevens dar de onderzoeksbevindingen met betrekking tot de predictieve warde en instrumentele utiliteit van de psychometrische onderzoeksgegevens met de nodige voorzichtigheid moeten worden geänterpreteerd. De conclusies van het onderzoek beperken zich vooralsnog tot de desbetreftende onderzoekspopulatie binnen de grenzen van de plats warop en het rijabescek warbinnen de onderzoeksgegevens zijn verzameld.

\subsection{VORM EN STRUCTUUR VAN HET ONDERZOEK}

Het onderzoek heeft een descriptief, exploratief en, voor zover de onderzoeksresultaten dat coelaten, prescriptief karakter.

Het descriptieve gedeelte heeft betreking op de beschrijving van de psym

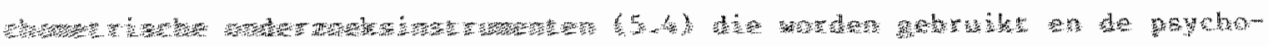

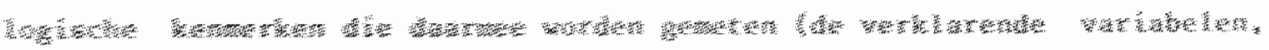
5

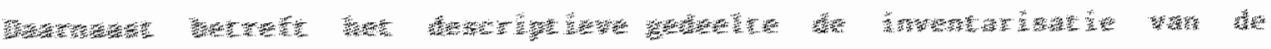

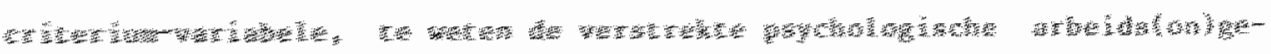

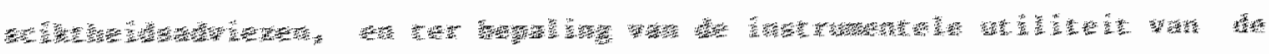

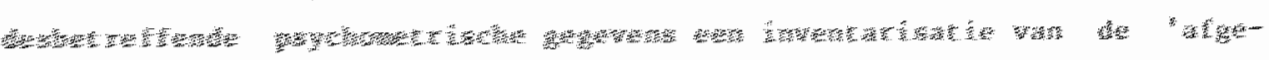

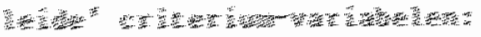

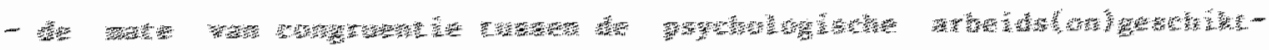

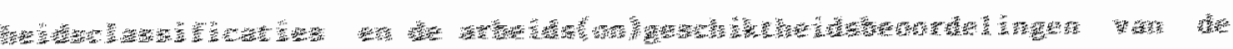

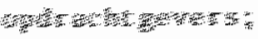


- de mate warin betrakkenen al of niet beroep hebben aangetekend tegen op de psychologische adwiezen gebaseerde "voor beroep vatbare beslissingen" van de opdrachtgevers;

- de mate warin in geval van beroepsaken er congruentie bestat tussen de prychologische arbeids(on)geschiktheidsclassificaties en de uiteindelijke beslissingen van de desbetreftende beroepsinstanties.

In het exploratieve gedeelte wordt ter bepaling van de worspellende warde van de verklarende variabelen nagegaan in hoeverre er significante werschilten zijn in biografische en psychologische persoonskenmerken tussen de subcategoriedu van respectievelijk:

- de betrokkenen die naar het oordeel van de psycholoog-adviseur arbeidsgeschikt en arbeidsongeschikt zijn;

- de betrokkenen wan wie de psychologische arbeids(on)geschiktheidsadviezen well en niet door de opdrachtgevers zijn overgenomen;

- de betrokkenen die wel en geen beroep hebben aangetekend tegen voor beroep vatbare beslissingen van de opdrachtgevers;

- de betrokkenen van wie de beroepen door de beroepsinstanties wel en niet gegrond is verklaard.

Het prescriptieve gedeelte berust op de bevindingen en analyses van het descriptieve en explotatieve deel van het onderzoek en geeft aan welke psychometrische gegevens een voorspell lende warde hebben ten aanzien van:

- de pychologische arbeids(on) geschiktheidsclassificaties;

- de beslissingen van de opdrachtgevers;

- de beslissingen wan betrokkenen om wel of niet in beroep te gan;

- de beslissingen wan de beroepsinstanties in geval van beroepsaken.

op grond daarvan kumen anbevelingen en voorstellen worden gedaan met betrekking tot een antal (voorlopige) beslissingsregels en om bepalde (combinaties van) psychometrische onderzoeksinstrumenten standaard te gaan gebruiken in het kader van psychologische arbeids(on)geschiktheidsdiagnostiekt.

In aansluiting op de procesgang van de arbeids(on)geschiktheidsbeoordeling (atie 2.5) en de onderzoeksvragen kan de structuur van het onderzoek als volgt schematisch worden weergegeven. 
Selveme 8: Seructur wan het onderzoek

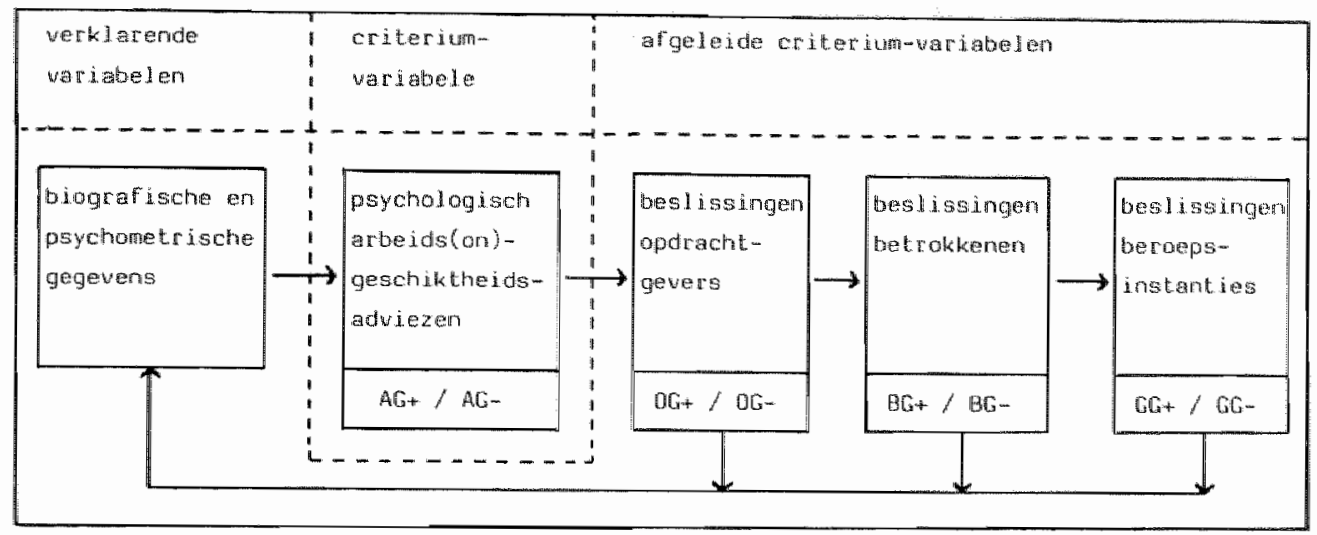

Aan de hand van de onderzoeksvragen, vorm en structuur van het onderzoek kan er onderscheid worden gemaak in de volgende fasen:

Fase 1: onderzoeking en beschrijving vam de getalsmatige gegevens van de criterium-variabele $(6.1)$.

Fase 2: onderzoeking en beschrijving van de mate van overeenkamst tussen de criterium-variabele (de verstrekte adviezen) en de afgeleide criterium-variabelen.

Daabij wordt aangegeven in hoevere op de psychologische adviezen gebaseerde 'voor beroep vatbare beslissingen' tot beroepsaken hebben geleid en in hoeverre dexe congegrond a in verklaard.

Fase 3: onderzoeking en beschrijuing van de voorspellende warde van de verklarende variabelen op univariat niveau met betrekking tot:

- de psychologische arbeids(on)geschiktheidsclassificaties;

- het advies-overnamebeleid van de opdrachtgevers;

- de beslissingen van de betrokkenen;

- de beslissingen van de beroepsinstanties.

Fase 4: onderzoeking en beschrijving van de voorspeltende warde van de biografische en psychologische persoonskemerken op multivariaat 
niveau ten anzien wan de psychologische arbeids(ongeschiktheids classificatien.

Pase 5: onderzoking en beschrijuing van de voorspeliende warde wan de biografische en psychologische persoonskenmerken op mult ivariaat niveau ten aanzien van het beslissingsbeleid van de opdrachtgevers, betrokkenen en beroepsinstanties.

Bovengenoemde fasering zal worden angehouden bij de beschrijuing en uitvoering van de onderzoeksresultaten in hoofdstuk 6.

\subsection{OHDERZOEKSTNSTRUMENTEN}

In djt onderzoek wordt gebruik gemakt van gestandardiseerde en genormeerde psychometrische onderzoeksinstrumenten, warvan de mate van betroubaarheid en validiteit bekend zijn en die teminste de wardering 'acceptabel' hebben gekregen van de Commissie Testangelegenheid (CoTAN) van het Nederlands Institutut van Psychollogen.

De keuze wan de desbetreffende instrumenten is gebaseerd op:

- de psychometrische kwaliteit (Visser e.a., 1982);

- een inventarisatie van psychologische persoonskenmerken die volgens de 1.jteratuur een zekere relevantie hebben met betrekking tot ziekteverzuim en arbeidsongeschiktheid (zie 3.5);

- de theoretische achtergrond van de psychologische arbeids(on)geschiktheidsdiagnostiek (aie 4.1);

- de beschikbarheid en de praktische toepasbaatheid (Lancée, $1981 \mathrm{c}$ ).

op grond van deze keuzecriteria is angenomen dat de gehanteerde onderzoeksinstrumenten klinisch relevante psychologische persoonskennerken en dimensies meten met betrekking tot de psychologische arbeids(on)geschiktheidsbeoordeling (zie ook Roe, 1984). Dit onderzoek is erop gericht on dit: t. bevestigen of te weer leggen.

De psychologische beoordeling van arbeids(on)geschiktheid is gebaseerd op de interpretatie van de kwaltatieve en kwantitatieve gegevens, betrekking hebbende op de psychische belestbarheid en beroepsvaardigheden. 
In ausluiting op voornomde keuzecriteria mag worden verondersteld dat de psychische belastbarheid en beroepsuardigheden zuch manitesteran als samengestelde tactor in:

- cognitief-incellectuele functies;

- kenis en (specifieke) vaardigheden;

- karakterstructur ;

- emotionaliteit en lichamelijke gevoelens;

- persoondijke warden, nomen, doelen, instelling en motivatie;

- affinteiten;

- gedrag en aanpassingsvermogen (aie ook 4.3).

De belastbaarheid en beroepswardigheden worden in dit onderzoek instumenteel gerealiseerd door niddel wan 34 psychologische persoonskenmerken (verklarende variabelen). Ter bepaling daarvan is in dit onderzoek gebruik gemakt van de volgende psychometrische tests, persoonlijkheids- en screeningsuragenlijsten:

- de Wechsler Adult Inteligence Scale (J. Stinissen e.a., 1970);

- de Differentiële Aanleg Test (S.D. Fokkena, A. Dirkzwager, 1968);

- de Nederlandstalige Minnesota Multiphasic Personality Lnventory (MMPI, C-vorto), (J. Nurtin en J.B. Beuten, 1969);

- de Amsterdamse Biografische Vragenlijst (G.J.S. Wilde, 1970);

- de Zelf-Beoordelings Vragenlijst (H.M. van der ploeg, P.B. Defares, C.D. Spielberger, 1980);

- de depressieschaal van Zung (1973);

- de Vragenlijst voot Onderzoek van de Ervaren Gezondheidstoestand (.I.M. Dirken, 1974);

- de Pijnschal (Fordyce, 1976).

Woor een nadere beschrijuing van deze onderzoeksinstrumenten en de psychologische persoonskenmerken wat deze betrekking op hebben, wordt verwezen natr bijlage $C$.

\subsection{OVERZICHT VAN DE VERKLARENDE VARTABELEN EN DE CRTIERIUM-VARTABELE}

De verklarende variabelen in he onderzoek zijn, nast de biografische 
gegevens betreftende geslacht, leeftijo en opleidingsiveau, de psychologische heriterken, zoals deze zijn getinwentariseerd me behulp van bovengenoemde psychonetische onderzocksingtrumenten.

Deze variabelen worden beschouwd als zogenamde potentiele 'voorspellervariabelen" van de criterium-variabele: de psychologische classificatie arbeidsgeschikt (AG+) versus arbeidsongeschikt ( $A G^{-}$).

Gegeven de darvoor bestemde wetcelijke criteria is bij deze clasificatie de volgende incleling gehanteerd:

I. geschikt voor eigen werk en/of vergelijkbare werkzaameden;

III. blijuend ongeschikt wor eigen enfof vergelijkbare werkzamheden, wel geschikt voor andere passende werkzamheden, eventueel na scholing;

II. voorlopig ongeschikt voor alle werkzaamheden;

IV. blijvend ongeschikt voor eigen en/of vergelijkbare werkzameden, voorlopig ongeschikt voor andere passende werkaamheden;

v. blijvend ongeschikt voor eigen en/of vergelijkbare werkzamheden en ook blijvend ongeschikt woor andere werkzambeden;

WT. reeds geheel, gedeeltelijk of voorspelbar (blijvend) arbeidsongem schikt bij aanvang der verzekering:

- geheel arbeidsongeschikt (artikelen: 44-la-le $Z W ; 21-1 a+21-2 b$ AAW; 30-la WAO; F 14-la ABP-wet);

- gedeeltelijk arbeidsongeschikt (artikelen: 5-IL AAW; 18-II WAO; F9-3 ABP-wet);

- voorspelbat arbeidsongeschikt binnen een half jaar na aanang der verzekering (artikelen: 44-la-2e $2 \mathrm{~m} ; 21-1 \mathrm{c}+21-1 \mathrm{~d}$ AAh, 30-lb WAO; $F \mid 4-1 b+F 14-2$ ABP-wet $).$

Voonoende categorisering van de psychologische adviezen makt vergelijking mogelijk met de beoordelingscategoriecen van de opdrachtgevers.

In verband met de probleemstelling van dit onderzoek betreffende de voorspelbatheid van de classilicatie arbeidsgeschikten versus arbeidsongeschikten (criterium-variabele) op basis van psychometrische gegevens, zijn bij de verwerking van de variabelen de categorieẻn $I$ en II samengevoegd: arbeidsgeschikt woor eigen en/of ander passend werk, eventueel na scholing $(A G+)$, terwijl categorie III tot en met VI zijn samengevoegd als zijnde én categorie: arbeidsongeschikt ( $\mathrm{AG}$ ). 
De verklarende variabelen en de criterum-variabele staan owerzichtelijk weergegeven in schema 9.

Schema 9: Overzicht werklarende variabelen en criterium-watiabeles

\begin{tabular}{|c|c|}
\hline werklarende variabelen & instrunent \\
\hline 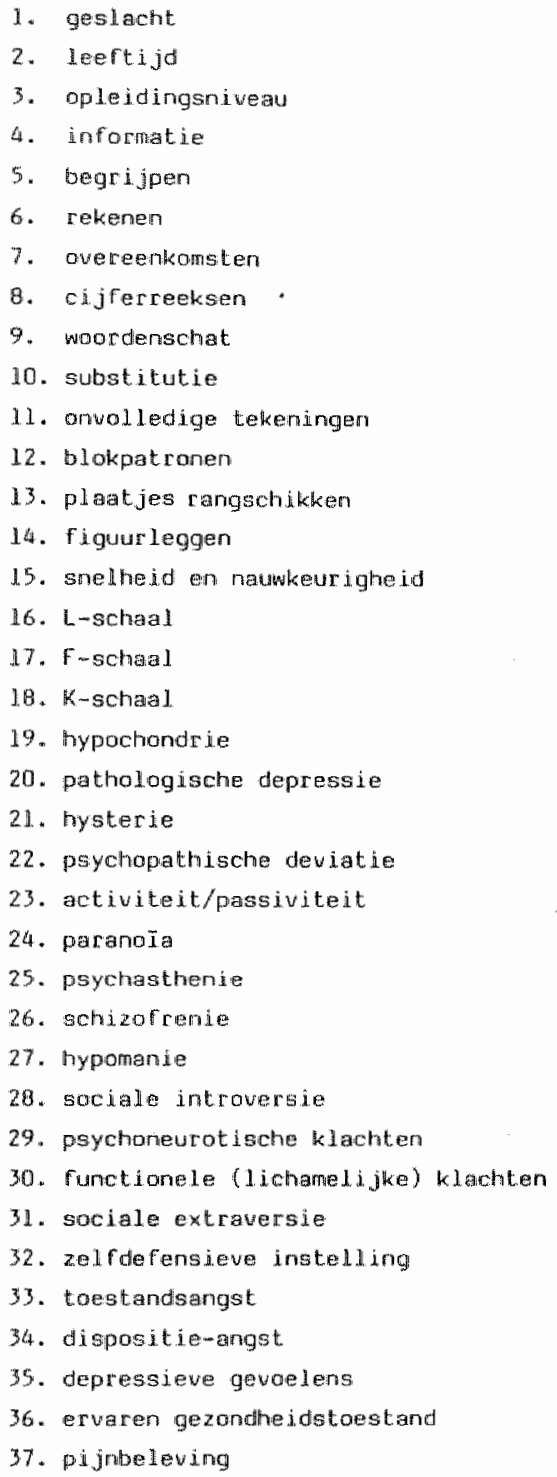 & $\begin{array}{l}\text { ZBU } \\
\text { ZIUNG } \\
\text { VOEG } \\
\text { PS }\end{array}$ \\
\hline
\end{tabular}

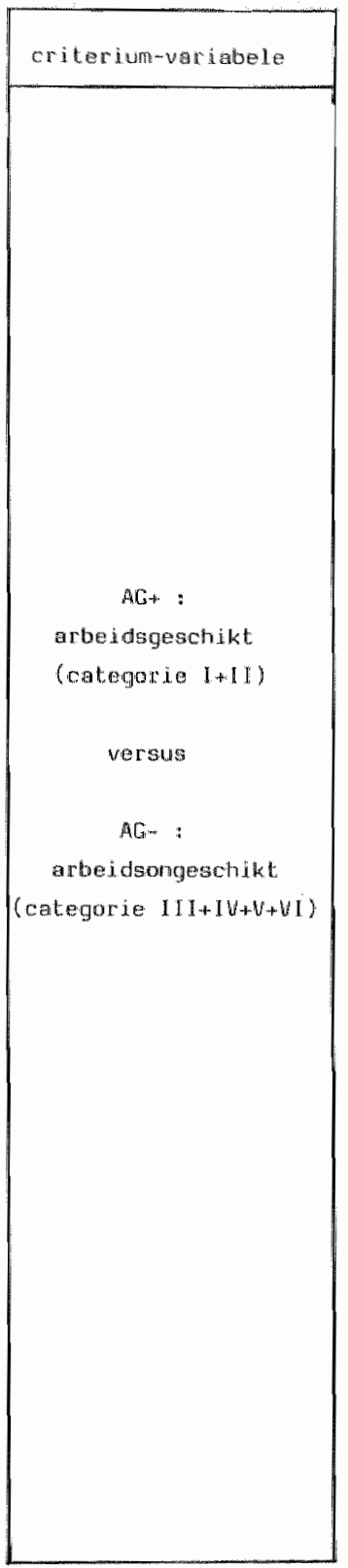


Wat betreft de 'objectiviteit van de criterium-variabele (AG+/AG-) is al eerder angegeven dat wegens de abezigheid van een operationele definitie en een txtern hard criterium wataan zou kunnen worden getoetst, in wetenschappelijk opicht niet geheel kan worden voldaan aan het 'objectiviteits" beginsel' (De Groot, 1972).

op grond van het gegeven dat de arbeids(on)geschiktheidsbeoordeling grotendeels berust op "experts-consensus" kan worden uitgegaan van de verondersteling dat de gewenste "objectiviteit" het dichtst worde benaderd door:

- de mate van overeenkonst tussen de adviezen van de psycholoog-adviseur en de beslissingen van de opdrachtgevers inzake de arbeids(on)geschiktheid van betrokkenen;

- de mate warin door de opdrachtgevers overgenomen adviezen wel en net hebben geleid tot beroepsaken;

- de mate warin beroepsaken hebber geleid tot (ongegrondverklaringen door de beroepsinstanties.

\subsection{ONDERZOEKSPOPULATIE}

De onderzokspopulatia wordt gevornd door de mensen die in de periode van 1981 tot en met 1984 door respectievelijk GMD, GAK en ABP (opdrachtgevers) zijn verwezen naar de psycholoog-adviseur van Psychologisch Adviesbureau Lancée te Alknar voor mader psychologisch onderzoek, met het verzoek een witspraak te doen ontrent de arbeids(on)geschiktheid wan de betrokkenen $(\mathrm{N}=322)$.

Verwijzing voor een dergelijk onderzoek vind plaats binnen het kader wan de sociale wetgeving door verzekeringsgeneeskundigen van woornoemde instanties. Bij de betrokkenen is voorat door middel van sonatisch-diagnostisch onderzok door de verwijzende verzekeringsgeneskundigen vastgesteld, dat ex op somatisch gebied geen of onwoldoende abjectiveerbare redenen anwezig zijn voor arbeidsongeschiktheid. Zij worden verwezen in het kader wh de vrag of er bij hen psychische gronden bestaan voor een eventuele arbe jongeschiktheid.

Het gat daabij om mensen met psychische en/of somatoforme verschijnselen, op grond warvan zij zichzelf niet in staat achten om te werken, ter- 
will de verzekeringsgeneeskundigen zich daarentegen arvergen in hoeverre zij wel tot werken in stat zijh, mar daaromtrent onvoldoende gegevens hebben om tot een adequate oordeelsvorming te komen. Die mensen van wie de verzekeringsgeneeskundige kan angeven dat er sprake is van een apert arbeidsbelemerend ziektebeeld, dan wel bij wie 'niets an de hand is", komen niet voor verwijzing in aanmerking en vormen derhalve geen onderdeel van de onderzoekspopulatie.

De onderzaekspopulatie bevindt zich op een voor de verzekeringsgeneeskundige onduidelijke plats op het continuim tussen arbeidsgeschikt en arbeilsongeschikt. Daabij is het de verzekeringsgeneeskundige met nane niet duidelijk hoe de verhouding psychische draglast/draagkracht ligt, noch wellke kans er bestaat op decompensatie bij verzwaring van de draaglast door een arbeidsgeschiktheidsverklaring af te geven.

Binnen de desbetreffende onderzoekspopulatie zijn de volgende categorieën te anderscheiden:

- mensen met vermeende cat arbeid belemerende psychische en/of persoonlijkheidsstoornissen;

- mensen met somatoforme klachten zonder aantoonbare arganische basis, al of niet als uiting van onderliggende psychische problemen en/of mentale overbelasting;

- mensen bij wie somatische ziekten of klachten als luxerend moment voor latente psychische problemen kunnen worden gezien;

- mensen met psychische klachten, symptomen en/of stoornissen ten gevolge van somatische ziekten of gebreken, welke op zich geen reden voor arbeidsongeschiktheid zijn.

Een retrospectief veldonderzoek beperkt de samenstelling van de onderzoekspopulatie. Mensen van wie geen informatie bij de opdrachtgever bekend was ontrent 'de wettelijke arbeidsongeschiktheidsbeoordeling na het psychologisch advies", zijn niet in het onderzoek betrokken $(n=6)$. Ook zij van wie er onvoldoende psychologische gegevens verzameld en/of beschikbar waren, zijn buiten de onderzoekspopulatie gelaten ( $\mathrm{n}=3$ ).

op ethische gronden is de mening gerespecteerd van hen die geen toestemming gaven tot gebruik van hun onderzoeksgegevens $(n=9)$.

Van het totaal aantal psychologisch onderzochte personen over wie een ar- 
beids(on)geschiktheidsadvies is uitgebrache $(N=822)$, zijn er derhalve 18 niet in de onderzokspopulatie opgenomen.

Van de resterende onderzoekgroep $(M=804)$ zijn de biografische gegevens wat betreft leeftijd, geslacht en opleidingsniveau ge invencariseerd; enerzijds ter beschrijving van de onderzoekspopulatie en anderzijds on te verkennen of deze variabelen mede een voorspellende warde hebben met betreking tot de psychologische arbeids(on)geschiktheidsclassificaties (criterium-wariabele).

De verdeling van de onderzoekspopulatie naar verwijzende instanties (opdrachtgevers), te weten GMD-kantoren Alkmar en Haarlem, ABP-kantoren Alkmar en Diemen en GAK-districtskancoor Alkmat, is gespecificeerd in tabel. 3 .

Tabel 3: Verdeling wan de ondorzoekspopulatie nas opdrachtgevers

\begin{tabular}{|c|c|c|}
\hline Opdrachtgevers & $\begin{array}{l}\text { absolute } \\
\text { frequentie }\end{array}$ & $\begin{array}{l}\text { relatieve } \\
\text { frequentie }(\%)\end{array}$ \\
\hline GMO & 647 & 80 \\
\hline ABP & 76 & 10 \\
\hline GAIK: & 81 & 10 \\
\hline totaal & 804 & 100 \\
\hline
\end{tabular}

Uit een mondeling gehouden enquete bij de betrokker opdrachtgevers is gebleken dat de verhouding in de relatieve frequentie van verwijzingen voor psychologisch onderzoek naar arbeids(on)geschiktheid overeenkont met het landelijk verwijzingspatroon van deze instanties.

zonder dat het exact is te staven, mag redelijkerwijs worden verondersteld dat het verschil cussen de opdrachtgevers wat betreft het aantal verwijzingen voor psychologisch onderzoek samenhangt met de respectievelijk verschillende taken die zij in het kader van arbeids(on)geschiktheidsbeoordeling hebber. Zo onderzoekt het GAK voor de niet-zelfadministrerende bedrijfsverenigingen voornamelijk mensen die nog in de ziektewet zitten en derhalve in eerste instantie alleen moeten worden beoordeeld op hun (on)geschiktheid voor het eigen latst uitgevoerde werk. Dit in tegenstelling 
tot de GMD, die als adviserende instantie van alle bedrijfsverenigingen cen algemene arbeids(on)geschiktheidsbeoordeling geeft over alle betrokkenen die aansprak maken op een uitkering krachtens de AAh en WAO.

Het relatief geringe aantal verwizingen wan het ABP hangt naar alle warschijnlijkheid samen met het feit dat via de ABP-wet verzekerde mensen pas daadwerkelijk door verzekeringsgeneeskundigen van het ABP worden onderzocht en eventueel door hen voor psychologisch arbeids(on)geschiktheidsonderzok worden werwezen, wanneer er sprake is van een mogelijke blijvende ongeschiktheid voor het eigen latst witgevoerde werk. Bij een voorlopige arbeidsongeschiktheid voor het eigen werk ligt de oordeelsvorming daaromtrent in eerste instantie bij de betrokken bedrijfsarts. In de dagelijkse praktijk wordt het steeds meer gebruikelijk dat ABP-verzekerden door de bedrijfsarts worden verwezen voor psychologisch onderzoek, nadat daaromtrent overleg is gepleegd met de verzekeringsgeneeskundige wan het $A B P$.

Ondat het geslacht, de leeftijd en het opleidingsniveau op grond wan beschikbare databestanden een zekere relevantie blijken te hebben ten aanzien van de groep mensen met een arbeidsongeschiktheidsuitkering (De Klerk e.a., 1983, 1985, 1986), zijn verwolgens deze biografische persoonskenmer ken van de onderzoekspopulatie geinventariseerd en onderstaand beschreven in paragraaf 5.6.1 tot en met 5.6.3. De representativiteit van de onderzoekspopulatie met betrekking tot deze biografische gegevens wordt aangegeven door vergelijkingen te maken met het landelijk totaal aantal AAW/WAO-uitkeringsgerechtigden. Deze biografische gegevens worden bij de analyse van de onderzoeksbevindingen betrokken, teneinde na te gaan in hoeverre ze mede een voorspellende warde hebben met betreking rot de psychologische arbeids(on)geschiktheidsclassificaties, de beslissingen van de opdrachtgevers, betrokkenen en beroepsinstanties.

\subsection{Verdeling naar geslacht}

De totalverdeling binnen de onderzoekspopulatie naar geslacht van de verwezen personen (rie tabel 4) is 534 mannen en 270 wrowwen, dat wil zeggen ongeveer tweemaal zoveel mannen als vrouwen. 


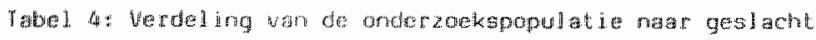

\begin{tabular}{|c|c|c|}
\hline Geslacht & $\begin{array}{l}\text { absolute } \\
\text { rogueritis }\end{array}$ & $\begin{array}{l}\text { relatiove } \\
\text { requente (s) }\end{array}$ \\
\hline Man & 534 & 56 \\
\hline Vroust & 270 & $3 / 4$ \\
\hline total al & 804 & 100 \\
\hline
\end{tabular}

De percencuele verhouding tussen mannen en vrowben, respectievelijk $66 \%$ versus 34\%, ea de totale uitkeringsgerechejgde populatie, respectiewelijk 68\% mannen versus $32 \%$ vroumen (Bruinsme e.a., 1987 ), wijst op een vrijwel evenredige verwijzing.

Wh betreft het totale ziekteverzuim, barin er zowel sprake kan zijn van voorlapige als blijwende arbeidsongeschiktheid, blijkt dat in iggs het percentage vrouwen dat zich ziek heeft gemeld hoger ligr (9, l\%) dan het aantal mannen $(7,2 \%)$, hetgeen is weergegeven in onderstande grafiek 2.

Grafiek 2: De ontwikkel ingen van het verzuimpercentage in Nederland over de periode 1959-1983; mannen resp. wrouwen

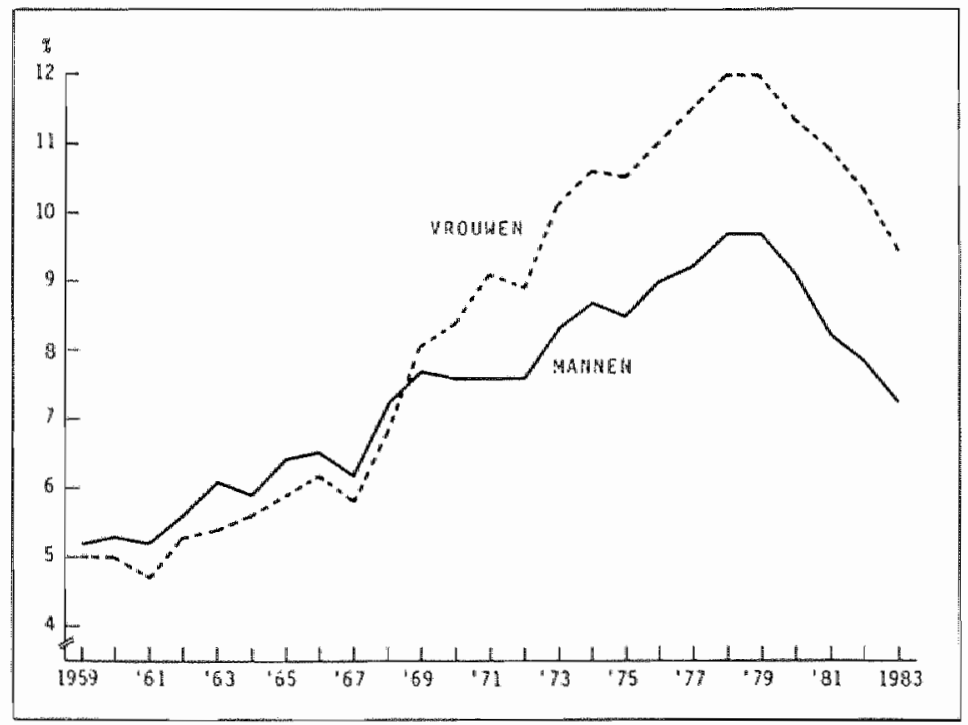

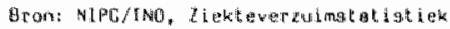


Wit een recent onderzoel wan het GAK naar deze verzuimuerschillen tussen mannen en vrowen in 1983 blijkt dat deze percentages over de hele populatie "arbeidsongeschikten" nagenoeg gelijk liggen, na correctie op (net zutheverlof wettelijk gelijkgesteld) zwangerschaps- en bevallingsverlot (Persbericht GAK, I april 1987).

In geval van de specifieke diagnosegroep "psychische stoornissen" is ech" ter percentagegewijs het aatal vrowwen dat arbeidsongeschikt is hoger dan het aantal arbeidsongeschikte mamen (Besselling en Bruinsma, 1986).

Uit het leeftijdsonderzoek 1980 en 1983 van het CBS (1984) blijkt dat vrowwen meer last hebben van psychische en psychosomatische klachten dan mannen. Uit het onderzoek van Bruinsma e.a. (1987) naar sociale indicatoren woor arbeidsongeschiktheid blijkt bij de vrouven $34 \%$ van de arbeidsongeschiktheid primair te worden toegeschreven aan psychische oorzaken, terwijl dat bij de mannen $25 \%$ bedraagt.

De oorzak wan deze verschillen wordt toegeschreven aan de combinatie van een aantal factoren, waronder o.a.:

- de dubbele belasting van vrouwen wegens de an werk gerelateerde stress en daarnast de zorg voor het huishouden en de kinderen (philipsen, $1977)$;

- biologische verschillen, geparar gaand met chronische aandoenünen en cyclische klachten en mogelijk daarmee samenhangende verschillen in beleving van de psychische stabiliteit (oudendijk, 1983);

- een relatief geringere psychische belastbaarheid, tot uiting komend in lagere scores op de schalen voor zelfwardering (Ormel, 1980) en hogere scores op de schalen voor neuroticisme en gezondheidsbeleving (Bruinsma, e. a., 1987).

\subsubsection{Verdeling naar leeftijd}

De verdeling naar leeftijd van dé onderzoekspopulatie ten tijde van het psychologisch onderzoek is weergegeven in tabel 5 .

Uit deze tabel blijkt dat de leeftijdscategorie van 16 tot 45 jaar de grootste categorie binnen de onderzoekspopulatie vormt ( $88 \%$ ). 


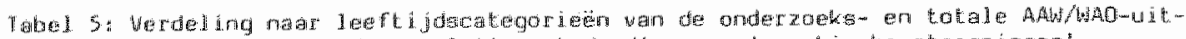
keringogerechtigde populat wet de diagnose "psychische stoornissen"

\begin{tabular}{|c|c|c|c|c|c|}
\hline \multirow[b]{2}{*}{$\begin{array}{l}\text { Leftijos } \\
\text { categorie }\end{array}$} & \multicolumn{3}{|c|}{ onder zoekspopulatie } & \multicolumn{2}{|c|}{ totale populatie } \\
\hline & $\begin{array}{l}\text { abeolute } \\
\text { frequent ie }\end{array}$ & 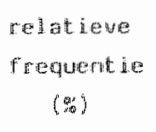 & 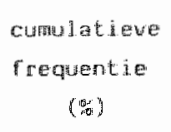 & 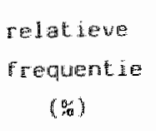 & $\begin{array}{c}\text { Cumulatieve } \\
\text { frequentie } \\
\left(\begin{array}{c}0 \\
0\end{array}\right)\end{array}$ \\
\hline $36-25 \mathrm{j}, \mathrm{mr}$ & 130 & 17 & 17 & 9 & 5 \\
\hline $26-353$ a & 349 & 43 & 61 & 15 & 24 \\
\hline $36-45$ ja & 222 & 20 & 89 & 20 & 44 \\
\hline $46-55$ jaar & 92 & 10 & 98 & 24 & 68 \\
\hline $546_{2}-65$ j $28 \mathrm{r}$ & $1 / 4$ & 2 & 100 & 32 & 100 \\
\hline Cotatis & 804 & $\$ 00$ & & 100 & \\
\hline
\end{tabular}

De gegevens van tabel 5 betreffende de leeftijdsopbouw van de onderzoekspopulatie zijn grafisch weergegeven in grafiek 3 . Daarin is tevens ter vergelijking de verdeling natr leettijdscategorieën opgenomen wan de totale AAW/WAO-uitkeringsgerechtigde populatie (GMD Jaarverslag: Statistische informatie, 1984).

Uit deze gegevens kan worden geconcludeerd dat het verwijzingsbeleid van de opdrachtgevers wat betreft de leeftijdscategorieën weinig parallelliteit vertoont met de totale AAw/WA-uitkeringsgerechtigde populatie.

De categorie 26 mot $35-j a r i g e n$ is relatief het meest verwezen voor psychologisch onderzoek in verband met mogelijke arbeidsongeschiktheid (43\%), gevolgd door respectievelijk de categorie 36-tot 45-jarigen (28\%) en 16tot 25 -jarigen $(17 \%)$.

Gezien het verwijaingsbeleid wordt door de opdrachtgevers verwacht dat relatief jonge mensen, na een tijdelijk onderbroken loopbaan wegens arbeidsongeschiktheid, eventueel met behulp van therapie, begeleiding, om-, her- of bijscholing, nog een reejle kans hebben om weer terug te keren in het arbeidsproces.

Dikwijls wordt een psychologisch advies dan ook niet alleen gevraagd on een uitspraak te doen over de arbejds(on)geschiktheid, maar tevens om daarbij an te geven voor welke vorm van behandeling of begeleiding betrokkene 
Crafiek 3: Leefti josopboum van do onderzoekspopulat is an de to-

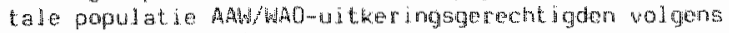

GHD Jarwarsalan 1984

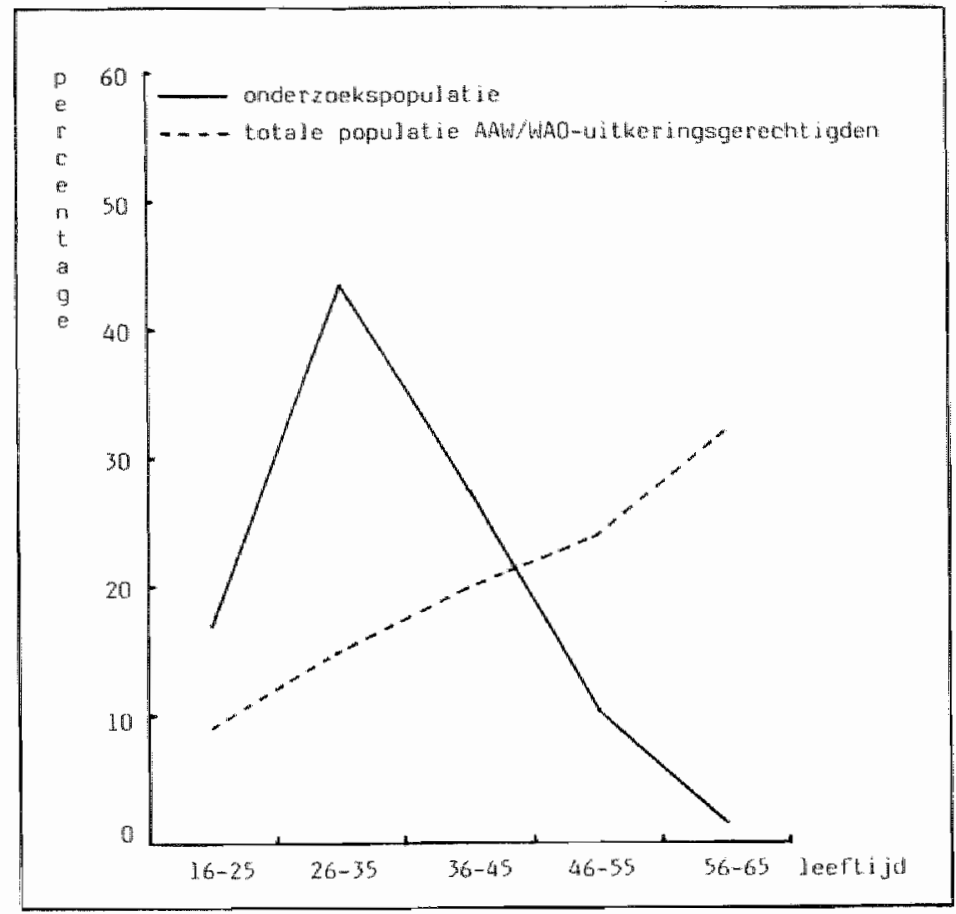

in aamerking komt en in toeverre on-, her- of bijscholing mogelijk is, teneinde langdurig ziektewerzuim en (blijvende) arbeidsongeschiktheid te voorkomen.

De praktijk wijst uit dat vooral scholing de kans van slagen van een reincegratiepoging vergroot (Kooreman en Groot, 1984). Scholing wordt als reintegratie-instrument voomamelijk toegepast bij de categorie 26 - tot 35-jarigen. Uit het GMD Jaarverslag van 1985 blijkt dit 77 van het total van deze voorziening te zijn.

Een hogere scholingsgraad en een hoger opleidingsniveau verkleint de kans op arbeidsongeschiktheid. Deze verminderde kans wordt grotendeels verklaard uit verschillen in de kwaliteit van de arbeid die men met de respectievelijke niveaus van oplaiding kan verrichten (Kruidenier, 1980; Nijhuis en Soeters, 1982; Smulders, 1984), en de daamee samenhangende verschillen in taak-intrinsieke arbeidssatsfactie (Ris, 1977). 
Volgens een malyse wan Schellart (1987) van de onderzotkgegevens van het CBS (1984) is ex sprake van een hogere belastbarheid naarmate het opleidingsiveau hoger is. Het is overigens in dit verband relevant on nogmals te wijzen op de bevindingen wan De klerk e.a. (1985, 1986) dat w vergeleken met de andere diagnosecategoriean onder de diagnosegroep psychische stoornisen juist en relatief groot antal thoger opgelleide arbeidsongeschikten ressortert.

Het feit dat ex ondanks een goed scholingsniveau tach sprake kan zijn van arbeidsongeschiktheid op psychische gronden kan worden geinterpreteerd als een aanwijzing dat andere persoonsgebonden factoren dan het scholingsniveau de psychische bellastbarheid mede bepalen.

\subsubsection{Verdeling naar opleidingsniveau}

De verdeling van de onderzoeksgroep naar opleidingsniveau is weergegeven in tabel 6 .

Tabel 6: Verdeling van de onderzockspopulatie naar oplejdingsniweau

\begin{tabular}{|c|c|c|c|}
\hline Op le idingeniveau & $\begin{array}{c}\text { absolute } \\
\text { frequentie }\end{array}$ & $\begin{array}{l}\text { relatieve } \\
\text { frequentie } \\
(\%)\end{array}$ & $\begin{array}{l}\text { cumulaticue } \\
\text { frequentie } \\
\text { (os) }\end{array}$ \\
\hline 1. Lager Onderwijs ( LO, 6 & 291 & 35 & 35 \\
\hline $\begin{array}{l}\text { 2. Voortgezet Lager (Beroeps-) } \\
\text { Onderwijs (LTS, LEAD, LAVO, } \\
\text { (VGLO, LHNO) }\end{array}$ & 228 & 28 & 63 \\
\hline 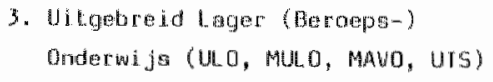 & 88: & 11 & 74 \\
\hline $\begin{array}{l}\text { 4. Middelbaer Beroeps-0nderwi js } \\
\text { (MIS, Vorplecgk.opl., MEAO) }\end{array}$ & 75 & 9 & 84 \\
\hline 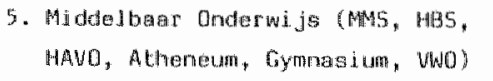 & 62 & 7 & 9.1 \\
\hline $\begin{array}{l}\text { 6. Hoger Beroeps Underwi jo (HTS, } \\
\text { (Ped.Academie, HEAO, LO-akten) }\end{array}$ & 26 & 3 & 95 \\
\hline 7. Universitair Dnderwi js, Mo-akten & 4.4 & 6 & 100 \\
\hline totas 1 & 804 & 100 & \\
\hline
\end{tabular}


Bij deze verdeling is gebrik genatk van de categorieën, zoals die worden gehanterd door de Socialle Vertekeringsraad. Bij de indeling van onderzoch ten in deze categorieën is het hoogst genoten en met diplona afgeronde opleidingsaiveau van vór de uitval uit het abeidsproces gehanteerd. Uit tabel 6 blijkt dat bijna $75 \%$ van de onderzoekspopulatie scholing op een relatief lag niveau en $25 \%$ middelbare of hogere scholing heeft gevolgd.

Wergelijking wan de verdeling nat opleidingsniveau binnen de onderzoeksgroep met die van respectievelijk de totale groep witkeringsgerechtigden (Kooreman en Groot, 1984) en de werkende beroepsbevolking (CBS Jarrstatistiek van de bevolking, 1983) is percentagegewijs weergegeven in tabel 7.

Tabel 7 : Percentuele verdeling naar opleidingsniweau ven de onderzakspopulatie in vergelijking met het total ant al witkeringsgerechtigden wolgens de AAb en WAO en de werkende beroepsbevolking.

\begin{tabular}{|c|c|c|c|}
\hline Opleydingsniveau & $\begin{array}{c}\text { onderzoeks- } \\
\text { propulatia } \\
\left(\begin{array}{l}\left(\frac{8}{0}\right) \\
0\end{array}\right)\end{array}$ & $\begin{array}{l}\text { witkerings- } \\
\text { gerechtigden } \\
\qquad 6)\end{array}$ & $\begin{array}{c}\text { werkende beroeps- } \\
\text { bevolking } \\
(\%)\end{array}$ \\
\hline $1 \quad$ LO & 35 & 36 & 19 \\
\hline $2 \quad \mathrm{LBO}$ & 28 & 26 & 10 \\
\hline 3 Mavo & Ll & 21 & 21 \\
\hline $4 \quad M 80$ & 9 & 8 & 31 \\
\hline 5 HAWO/WWO & 8 & 5 & 11 \\
\hline $6 \mathrm{HaO}$ & 3 & 3 & 5 \\
\hline 7 Uniw. & 6 & 1 & 4 \\
\hline totaal & 100 & 100 & 100 \\
\hline
\end{tabular}

De gegevens wan rabel 7 zijn grafisch weergegeven in grafiek 4. Dadruit blijkt dat de verdeling naar opleidingsniveau binnen de categorieén uitkeringsgerechtigden volgens de AAW en WAO en de onderzoekspopulatie redelijk parallel lopen.

Een uitzondering op deze paralleliteit vormt de categorie 'uitgebreid lager onderwijs" (niveat 3), waarin ex percentagegewijs relatief meer uitkeringsgerechtigden zijn (21\%) dan er voor onderzoek zijn verwezen (11\%), warvoor op woorhand geen verklaring kan worden gegeven. 


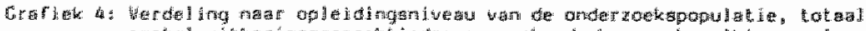

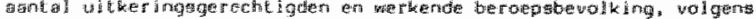

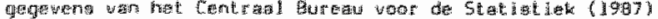

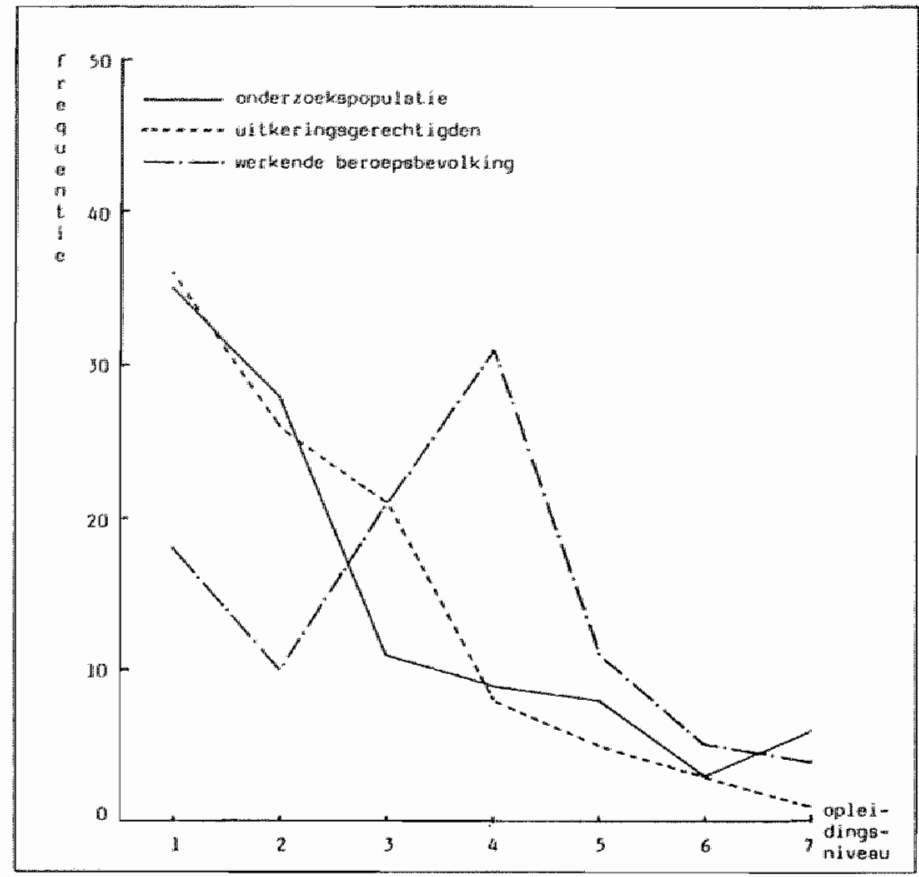

Wat betreft de verhouding tussen de uitkeringsgerechtigden en de verwezen populatie enerzijds en de verzekerde beroepsbevolking anderzijds op scholingsniveau 4 (middelbaar beroepsonderwijs), valt op dat op dit niveau relatiet de meeste mensen werkzaam zijn, terwijl vergeleken met de andere scholingsniveaus het percentage 'arbeidsongeschikten' gering is.

Het tegenovergestelde geldt woor de niveaus 1 en 2 , respectievelijk het lager en het voortgezet lager onderwijs. Het percentage uitkeringsgerechtigden is, evenals dat van de verwezen onderzoekspopulatie, werhoudingsgewijs aanzienlijk hoger dan het percentage mensen dat op dat niveau werlezanis.

Tenslote geelt dit cijfematerial een bevestiging van het gegeven dat het grootste gedeelte van de totale populatie uitkeringsgerechtigden tot de relatief lager geschoolden behoort ( $84 \%$ heeft lager, voortgezet en unitgebreid lager onderwijs genoten), terwijl dit ook de grootste groep vorm die voor onderzoek is verwezen (75\%). 
Sanengevat kan worden gesteld dat met betrekking tot de leefijidsopbouw van de onderzoekspopulat he voornamelijk de $16-t o t 45-j a r i g e n$ ain die voor psychologisch onderzok zijn verwezen, terwill de categotie mensen met de diagnose 'psychische scoornissen' boven de 45 jaar landelijk altijd $\operatorname{nog} 56 \%$ is.

Met betrekking tot de biografische gegevens wat betreft geslach en opleiAingsniveau van de onderzoekspopulatie kan worden gesteld dat deze in grote lijmen representatie kumen worden genoend voor de totale uitkeringsgerechtigde populatie in Nederland.

Gezien echter de opzet en uitvoering van het onderzoek mogen ondanks deze redelijke representativiteit in leatijd en opleidingsniveau vooralsnog geen onderzoeksresultaten, zoals hiervolgend beschreven in hoofdstuk 6 , worden gegeneraliseerd nar de totale (potencięle) AAw/WAO-uitkeringsgerechtigde populatie.

\subsection{METHODE VAN DATA-VERZAMELING}

Deze studie berust op gegevens die in de dagelijkse praktijk van de psycholoog-adviseur zijn verzameld en retrospectief door middel van dossierstudie zijn geinventariseerd. Het betreft een inventarisatie van onderzoeksgegevens van mensen die psychologisch zijn onderzocht op hun (resterende) psychische belastbarheid en beroepsvaardigheden im het kader yan hun arbeids(on) geschiktheidsbeoordeling.

Er heeft een inventarisatie platsgevonden van respectievelijk:

- een aantal biografische gegevens;

- een aantal psychologische persoonskenmerken;

- de verstrekte psychologische arbeids(on)geschiktheidsadviezen;

- de beslissingen van de opdrachtgevende instanties;

- de beslissingen van de betrokkenen;

- de beslissingen van de beroepsinstanties.

Deze gegevens zijn aan de hand van bestaande psychologische dossiers geüventariseerd, geanonimiseerd en gecodeerd. De formulering en codering van de adviezen heeft plaatsgewonden volgens een bij de opdrachtgevers 
gebruikelijhe indeling, rodat wergelijking van de psychologische adviezen met de beslissingen van de opdrachtgevers mogelijk is.

De beslissingen an de opdrachtgevers, betrokkenen en beroepsinstantias zijn door een antal verzekeringsgeneeskundigen van de advies- en uitvoeringsorganen aan de hand yan hun dossiers verzameld, geanonimiseerd en gecodeerd.

Het geheel van gegewens is in de periode van 1985-1986 verwerkt bij de statistisch-methodologische afdelling van de vakgroep Medische Psychologie van de Rijksuniversiteit Limburg (onder leiding van prof.dr. J.J.C. B. Bremer). 


\section{RESULTATEN EN DISCUSSIE}

In dit hoofdstuk worden, in ansluitung op de volgorde van de onderzoeksvragen $(5.2)$ en de structur van het onderzoek $(5.3)$, de resultater weergegeven van de analyses die hebben platsgevonden op het onderzoeksmaterial.

Ten eerste worden de onderzoeksbevindingen weergegeven die betrekking hebben op de beschrijving van de criterium-variabele en de afgeleide criterium-variabelen, respectievellijk:

- de verstrekte psychologische arbeids(on)geschiktheidsadviezen (6.1);

- de mate van overeenkomst tussen ce psychologische abeids(on)geschiktheidsadviezen en de beslissingen daaromtrent van de opdrachtgevers (6.2);

- het tantal mensen dat respectievelijk wel en geen beroep heeft angetekend tegen een 'voor beroep vatbare besilissing' (6.3);

- het antal mensen van wie het beroep door de rechterlijke instanties respectievelijk wel. en miet gegrond is verklaard (6.4).

Vervolgens wordt ter bepaling van de voorspellende waarde wan de verw klarende variabelen op univariaat niveau aangegeven in hoverre er daadwerkelijk significante verschillen in biografische en psychologische persoonskenmerken zijn geconstateerd tussen:

- de betrokkenen die door de psycholoog-adviseur als arbeidsgeschikt, respectievelijk arbeidsongeschikt zijn geclassificeerd (6.5);

- de betrokkenen van wie het psychologische arbeids(on)geschiktheidsadvies well, respectievelijk niet door de opdrachtgevers is overgenonen $(6,6)$;

- de betrokkenen die wel, respectievelijk geen beroep hebben aangetekend $(6.7) ;$

- de betrokkenen van wie het beroep wel, respectievelijk nite gegrond ig verklaard $(6.8)$.

Tenslatte worden de onderzoeksbevindingen beschreven van de aralyses met betrekking tot de voorspellende wardebepaling van de biografische en psychologische persoonskenmerken op multivariaat niveau cen aanzien van de psychologische arbeids(on)geschiktheidsclassificaties $(6.9)$ an het beslissingsbeleid van de opdrachtgevers $(6.10)$. 
Wegens onvoldoende respondenten binnen de respectievelijke subcacegorieen - beroepszaken en (on) hegrondverklaringen - heeft geen onderzoek plaats kunnen vinden naar de predictieve wardebepaling van de biografische en psychologische persoonskenmerken met betrekking tot het beslissingsbeleid van betrokkenen en de beroepsinstanties.

\subsection{DE VERSTREKTE PSYCHOLOGISCHE ARBETDS(ON)GESCHTKTHETDSADVLEZEN}

De psychologische arbeids(on)geschiktheidsclassificaties $z$ in door éen psycholoog adviseur in termen van een arbeids(on)geschiktheidsadvies geformuleerd.

De psychologische arbeids(on)geschiktheidsadviezen die aan de opdrachtgevers zijn verstrekt zijn ingedeeld in de zes eerder aangegeven categorieën (zie 4.3 .4$)$.

Gegeven deze arbeids(on)geschiktheidscategorieèn I tot en met VI, blijkt het total van de adviezen $(N=804)$ door de psycholoog-adviseur verstrekt an de opdrachcgevers, als volgt verdeeld:

ad. I : in principe weer geschikt voor eigen of vergelijkbaar werk: $n=$ $241=30 \%$ ( $18 \%$ mannen en $12 \%$ wrouwen);

ad.Il : ongeschikt voor eigen, mar wel geschikt voor ander werk, eventueel na aanvullende scholing: $\mathrm{n}=185=23 \% 619 \%$ mannen en $4 \%$ vrouwen); N.B. het kunnen volgen vam onderwijs impliceert ook een bepalde restcapaciteit tot het verrichten van in dit verband "scholingsarbeid';

ad.TI : voorlopig volledig arbeidsongeschikt: $n=236=29 \%$ ( $18 \%$ mannen en $(1 \%$ vrouwen);

ad.IV : blijvend ongeschikt voor eigen werk en voorlopig ook voor ander werk: $n=31=4 \%$ ( $2 \%$ mannen en $2 \%$ wrouwen);

ad.W : wolledig blijvend arbeidsongeschikt: $n=75=9 \%$ ( $2 \%$ mannen en $7 \%$ wounen);

ad.WI : reeds bij aanvang det verzekering arbeidsongeschikt: $n=36=5 \%$ ( $3 \%$ mannen en $2 \%$ vrouwen).

In de histogram van figur 2 worden deze verstrekce psychologische arbeids- 
(on)geschiktheidsadviezen verdeeld naar geslacht volgens de categoriewindeling I tot en met VI weergegeven.

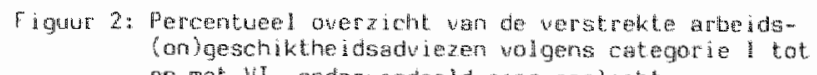

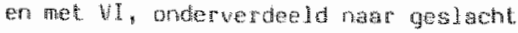

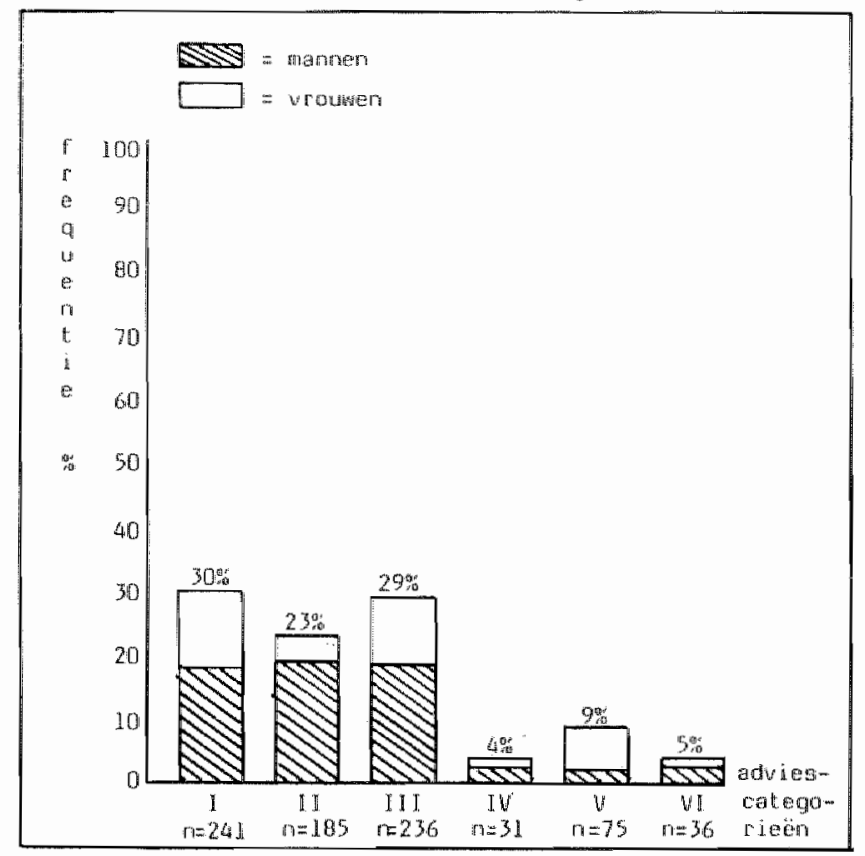

Uit Figutur 2 kan worden afgelezen dat zowel met betrekking tat de adviescategorieën I en IJ, zijnde geschikt voor eigen werk, respectievelijk ander passend werk, als ook categorie III 'voorlopig arbeidsongeschikt', de mannen de grootste groep vormen. Dit is in tegensteliling tot catcegarie W 'blijvend ongeschikt', warin de vrouwen het grootste andeel hebben.

Met betrekking tot de adviescategarie IV 'blijvend ongeschikt voor eigen werk, voorlopig ook voor ander passend werk' en categorie VI 'reeds arbeidsongeschikt bij aanvang der verzekering' liggen de verhoudingen tussen de mannen en vrouwen vrijwel gelijk.

Een indeling wolgens het dichotome criterium arbeidsgeschikt (AGt) wersus arbejdsongeschikt ( $\left.\mathrm{AG}^{-}\right)$, levert de valgende verdeling van de verstrekte psychologische adviezen op: 


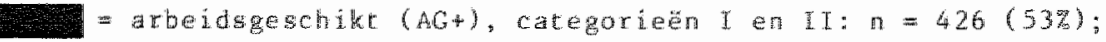

$J=$ arbeidsongeschikt $(A G-)$, categoriedn III tot en mer $1: n=378$ $(47 \%)$.

In figur 3 worden de adviseringscategoriean $A G+(53 \%)$ en $A G-(47 \%)$, verdeeld ratar geslacht weergegever.

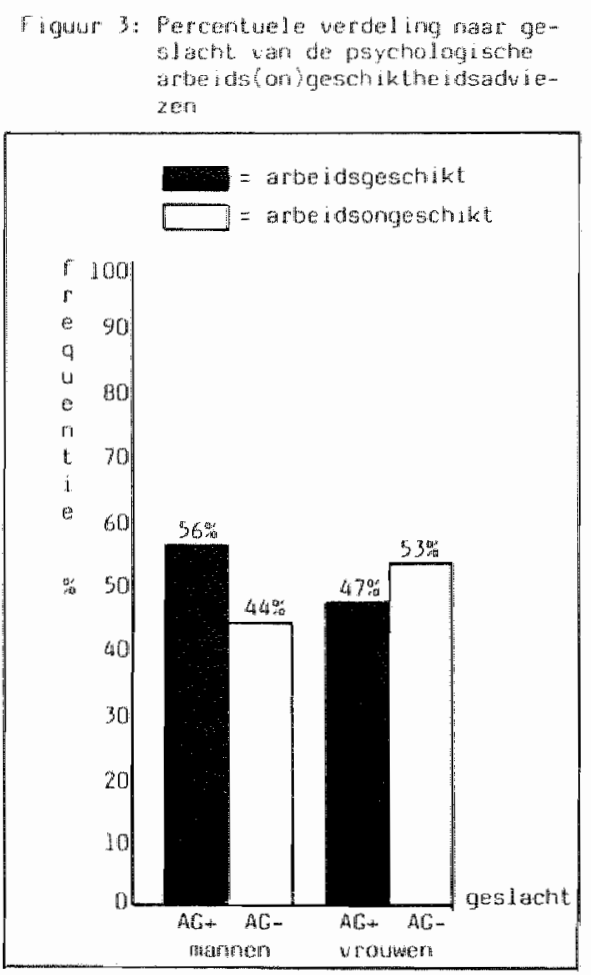

Uit de histogram van figune 3 blijkt dat in het total betreftende $56 \%$ van de mener en $47 \%$ van de vrouwen het psychologisch advies arbeidsgeschikt is witgebrach en vrijwel het ongekeerde beeld is ce zien wat betreft de arbeidsongeschiktheid: $53 \%$ van de vrouwen en $44 \%$ wan de mannen worden door de psychohoog-adviseur als arbeidsongeschikt beoordeeld. Het latste verschil tussen het antal mannen en vrowwen met eem arbeidsongeschiktheidsadvies is bij tweezijoige toetsing significant bijeg significantiegrens van $p<0.05(\operatorname{chi} 2=5.72, p=0.02)$. 
In figur 4 is de verdeling weergegeven van de adviezen arbeidsgeschikt $(A G+)$ versus arbeidsongeschikt $\left(\mathrm{AG}^{-}\right)$, ingedeeld nar leeftijdscategorieen.

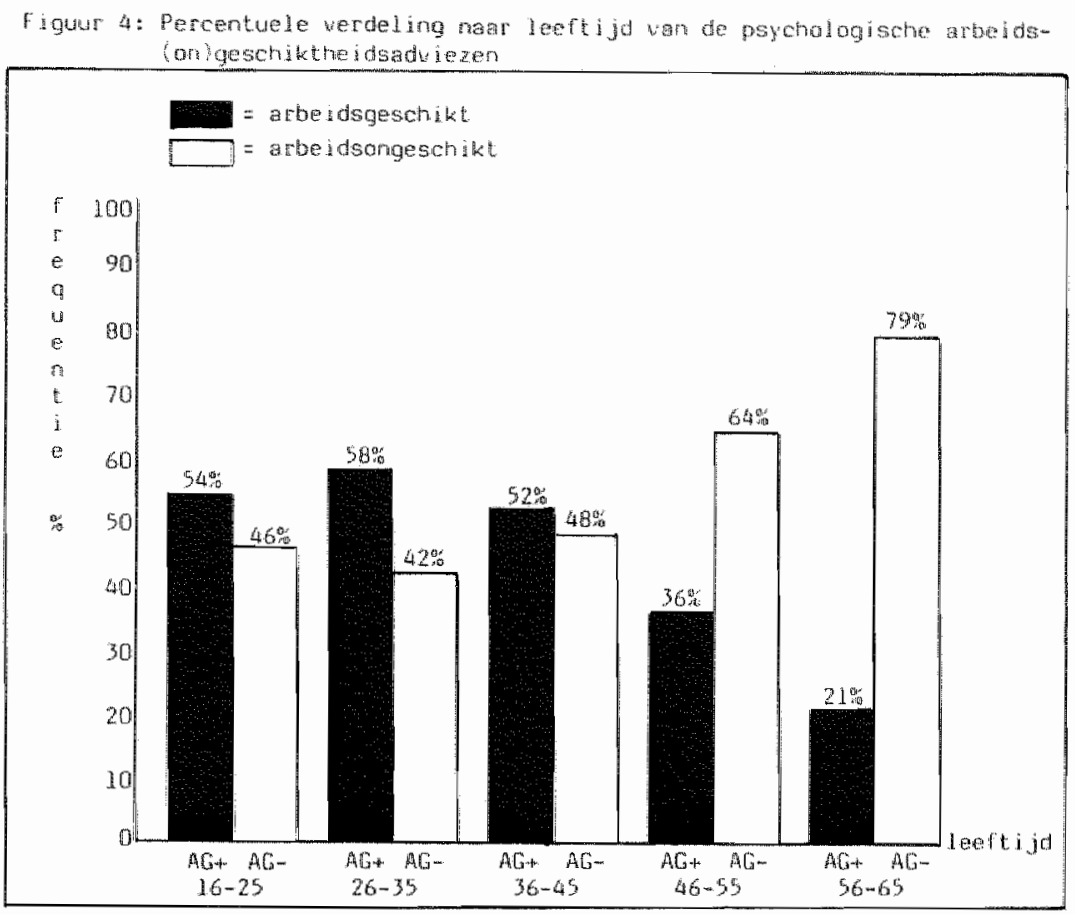

Wit de histogram van figuur 4 komt naar voren dat narmate de leeftija hoger is, het antal arbeidsongeschiktheidsadviezen toeneent. Het verschil in leertijd tussen de categorie arbeidsgeschikten en abeidsongeschikten is bij tweezijdige toetsing significant bij een significantiegrens van $p<$ $0.01(p=0.00$; zie tabel 16$)$.

De verdeling van het advies arbeidsgeschikt ( $A G+$ ) versus arbeidsongeschikt $(A G-)$ per leeftijdscategorie en ingedeeld naar gesiacht is percentagegewijs weergegeven in tabel 8 .

Uit tabel 8 blijkt dat er per leeftijdscategorie meer vrouwen dan manen door de psycholoog-adviseur arbeidsongeschikt worden beschouwd. 


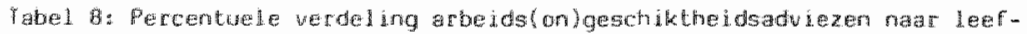
Lijot an ges bachl

\begin{tabular}{|c|c|c|c|c|}
\hline \multirow[b]{2}{*}{$\begin{array}{l}\text { Leeflijos- } \\
\text { categor Le }\end{array}$} & \multicolumn{2}{|c|}{ Grbeidsgesehikt } & \multicolumn{2}{|c|}{ arbeidsongeschikt } \\
\hline & $\begin{array}{c}\text { Manmen } \\
\left(\begin{array}{c}x_{x} \\
x^{\prime}\end{array}\right)\end{array}$ & $\begin{array}{c}\text { wrowien } \\
\left(\begin{array}{c}a \\
x\end{array}\right)\end{array}$ & $\begin{array}{c}\text { mannen } \\
\left(\begin{array}{c}\text { ce } \\
\text { a }\end{array}\right)\end{array}$ & $\begin{array}{c}\text { Hetowern } \\
(y)\end{array}$ \\
\hline $6-25$ & 59 & 54 & 4. & 46 \\
\hline $26 \rightarrow 35$ & 68 & 51 & 32 & 49 \\
\hline $36-45$ & 58 & 49 & 42 & 51 \\
\hline $46-55$ & 43 & 30 & 57 & 70 \\
\hline $56-65$ & 40 & 33 & 60 & 67 \\
\hline
\end{tabular}

De verdeling van het advies arbeidsgeschikt/arbeidsongeschikt, ingedeeld naar opleidingsniveau, is percentagegewijs in figuur 5 weergegeven.

Figur 5: Percentuele werdejing natr opledingsniveau van de psychologische arbejdsionlgeschiktheidsadviazen

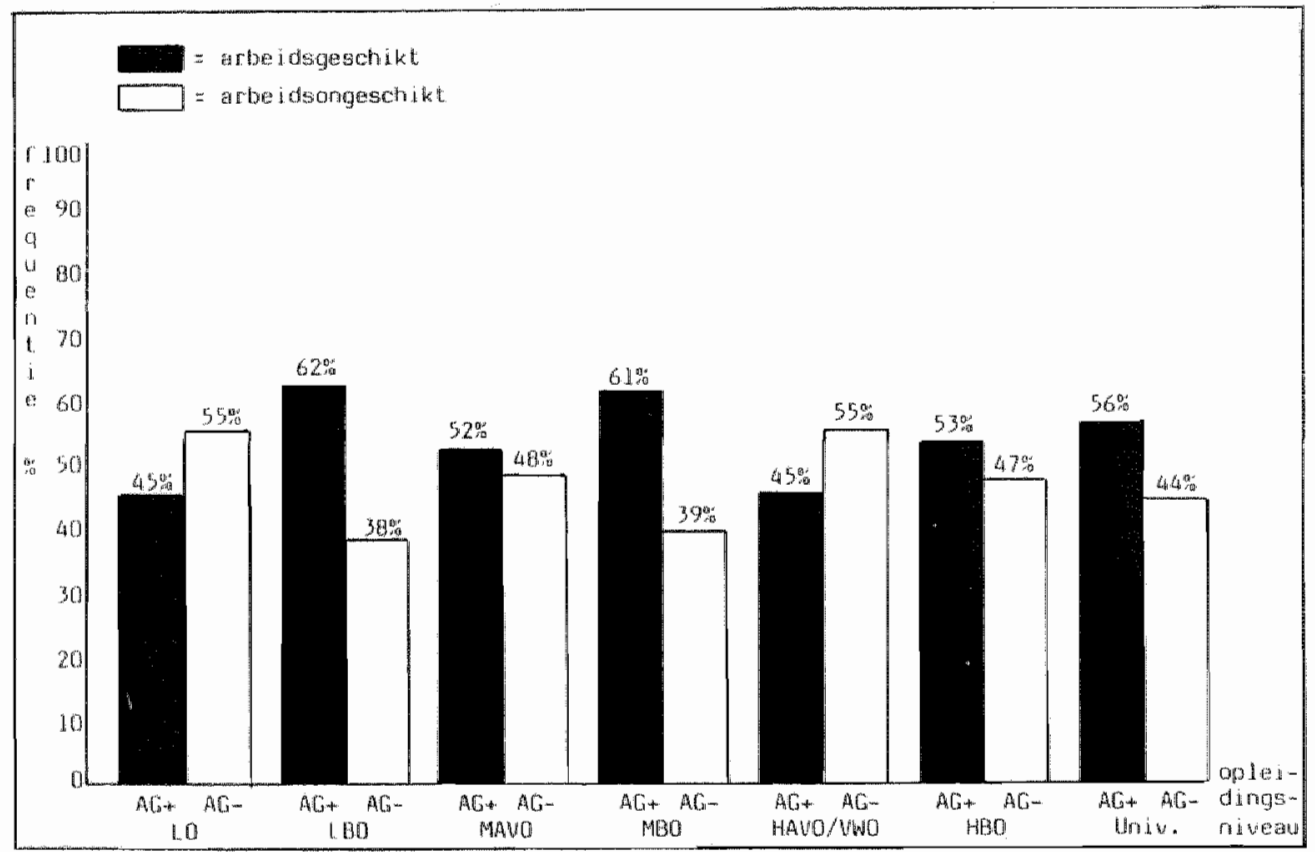

De histogram van figur 5 coont dat er per opleidingsniweau meer arbeidsge- 
schiktheids - dan arbeidsongeschikcheidsadwiezen zijn gegeven, met uitzondering wan het lagere school-(1) en middelbare schoolniveau (5), respectevelijk de minst geschoolden en de middelbar geschoolden, over wie in beide gevallen meer arbeidsongeschiktheids- dan arbeidsgeschiktheidsadviezen zijjn verstrekt.

Er is overigens door middel van een tweezijdige t-toetsing (spitz, 1965) geen significant verschil geconstateerd in opleidingsniveau tussen de categorieèn met het advies arbeidsgeschikt/arbeidsongeschikt bij een significantiegrens van $p<0.05(p=0.23$ : zie tabel 16).

In tegenstelling tot de eerder genoende onderzoeksbewindingen van Ris (1977), Kruidenier (1980), Nijhuis en Soevers (1982), Smulders (1984) en Schellart (1987), blijkt ex binnen deze onderzokspopulatie geen specifieke relatie aatoonbar te zijn tussen het psychologische arbeidsgeschiktheids- versus -ongeschiktheidsadvies en het oplaidingsniveau.

De verdeling van het advies arbeidsgeschikt (AG+) versus arbeidsongeschikt $\left(\mathrm{AG}^{-}\right)$naar opleidingsniveau en geslacht is percentagegewijs weergegeven in onderstaande tabel 9.

Tabel 9: Percentuelle werdeling arbe udo (on)geschiktheidsadviezen maar opleidingsrubeau en geslacht

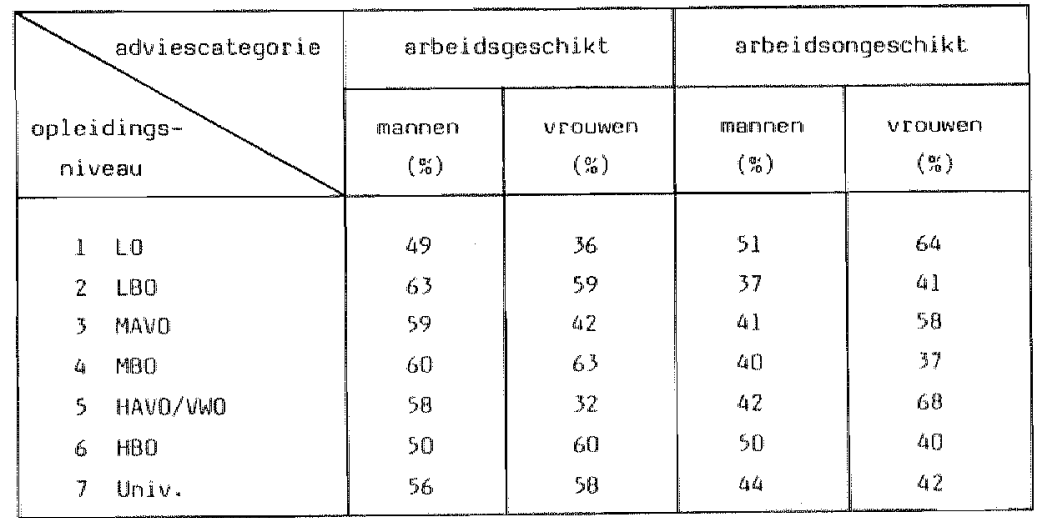

Uit tabel 9 blijkt dat met betrekking tot het opleidingsniveau in relatie tot de arbeidsongeschiktheidsadviezen, op de lagere niveaus (nival I lot en met. 3) relatief meer vrowwen dan mannen het advies arbeidsongeschikt krijgen. 
Damentegen krijgen op hogere niveaus (6 en 7) relatief meer manmen dan vrouwen het advies arbeidsongeschikt.

Een verklaring voor dit verschil in categorisering wat betreft arbeidsgeschiktheid versus arbeadsongeschiktheid naar geslacht en opleidingsniveau is op grond van de beschikbare onderzoeksgegevens niet te geven.

\subsection{Discussie}

Met betrekking tot de bevinding dat er door de psycholoog-adviseur sigmificant meer vrouwer dan mannen arbeidsongeschikt worden beoordeeld, kan worden gesteld dat dit overeenkomt net llandelijke onderzoeksgegevens van de GMD (CMD Jaarverslag 1981 tot en met 1985).

In het onderzoek van Bruinsma e.a. (1987) is nat voren gekomen dat mogelijk mede onder invloed van de toenemende arbeidsparticipatie het aandeel van de vrowwen onder de nieuwe arbeidsongeschikten voortdurend stijgt: het. bedragt nu landelijk over alle diagnosecategorieên $32 \%$.

Uit voonoemd onderzoek blijkt verder dat vrouwen vaker psychisch ziek zijn dan manen. Dit manifesteert zich niet alleen in een frequentere indeling. in de diagnosecategorie $V$ (psychische stoornissen), mar ook in de mate van psychisch onwelbevinden bij andere diagnosecategorieën.

De laatste jaren is er sprake van een relatief sterker toenemend roetredingspercentage van vrouwen dan mannen in de AAW/WAO wegens psychische stoornissen. Tegelijkertijd worden vrouwen wel weer eerder hersteld, c.q. arbeidsgeschikt verklaard dan mannen (Besseling en Bruinsma, 1986), al beperkt dit zich niet rot de categorie psychische stoormissen, maar geldt het voor alle diagnosecategorieën (Hermans, 1988).

De bevinding dat er een grotere kans is op een arbeidsongeschiktheidsadvies van de psycholoogadviseur narmate de leetijd hoger is, blijkt tevens volgens de eerder genoende GMD Jaarverslagen (1981 cot en met 1986) conform de landelijke trend bij de wetsuitvoerders te zijn.

De constatering dat er geen significante verschillen in de onderzoekspopulatie zijn wat betreft opleidingsniveau, kont overeen met andere recente onderzoeksuitkomsten van De Winter (1983), Meyman (1984), Van "t Hullenaar 
en Van Koningsveld (1986), Kompher e.a. (1986) en Van Dijk e.a. (1987).

Uit deze onderzoken is naar voren gekomen, dat hoge psychische belasting op alle niveaus van opleiding en werkaamheden voorkont en tot arbeidsbelenmerende stoornissen kan leiden, op grond warwan mensen arbeidsongeschikt worden beschouwd.

Voomoemde bevindingen nemen echter niet weg dat er onderzoekstesulaten zijn, die wel degelijk aangeven dat een geringe scholing de kans op arbeidsongeschiktheid vergroot (Wiersma, 1979; Kruidenier, 1980).

Dat in thet algemeen weinig scholing een relatief grotere kans op arbeidsongeschiktheid geeft, wordt volgens Bruinsma (1980) verklaard vanuit de mate waarin er juist in deze categorie sprake is van "verborgen werkloosheid". Dit laatste lijkt te worden bevestigd door het opvallend grote verschil tussen de vragg nat werk op scholingsniveau I (lager onderwijs) en het daadwerkelijke werkaanbod op dat niveau, zoals weergegeven in tabel 10.

Tabel 10: Overzicht var aantal werkloze mannen en vrouwen nar scholingsniveau in relatie tot het aental openstagnde vacatures in $1995 *$

\begin{tabular}{|c|c|c|c|c|c|}
\hline \multirow[t]{2}{*}{ Schol ingsniveau } & \multicolumn{3}{|c|}{$\begin{array}{c}\text { Aantal werkloze mannen } \\
(x 1000)\end{array}$} & \multirow{2}{*}{$\begin{array}{l}\text { Openstaande } \\
\text { vacatures } \\
(x \perp 000)\end{array}$} & \multirow{2}{*}{$\begin{array}{l}\text { Weachil wrago/aanood } \\
\text { van werk } \\
(x, 1000)\end{array}$} \\
\hline & märnen & Vrouwen & toteal & & \\
\hline $\mathbb{1}$ & 140 & 80 & 220 & 46 & -174 \\
\hline 2 & 33 & 37 & 67 & 22 & -45 \\
\hline 3 & 96 & 64 & 160 & 204 & +44 \\
\hline 4 & 19 & 15 & 34 & 21 & -13 \\
\hline 5 & 69 & 58 & 127 & 215 & +89 \\
\hline 6 & 21 & 24 & 45 & 120 & +75 \\
\hline 7 & 10 & 6 & 16 & 29 & $4 \quad 13$ \\
\hline
\end{tabular}

Schol ingsini veaus:

$1=$ lager onderwijs (LO, BLO)

2 = voortgezet lager (beroeps-) bnderwijs (LTS, LEAO, LAVO, VGLD, LHNO)

$3=$ uitgebreid 1 ager (beroeps-)onderwijs (ULo, Mulo, Mavo, UTS)

4 = midolelbar beroepsonderwijs (MTS, verpleegk.opl., MEAO)

5 - middelbaer onderwijs (MS, HAS, HAVO, atheneum, gymas ium, Vwo)

$6=$ hager beroepsonderwijs (HTS, Ped. Acadenie, HEAO, LO-akten)

$7=$ thiwersitair onderwi js, Mo-akten

* Met dank an dr. H.G.S.J. van Maraveen, hoofd der hoofdafdeling Statistiek van Arbeid en Lonen wan het Central Bureau voor de Statistiek, voor de offerte wan de gegevens, aan de hand warvan deze tabel is samengegteld. 
Waron er tevens op scholingsiveau 5 (middelbar niveau) relatief meer arbeidsongeschikcheids- dan -geschiktheidsadviezen zijn gegeven, hangt gezien de gegevens van tabel 10 niet samen met de verhouding tussen aabot van en wragis naar werk, ondat er meer a anbod vam werk is dan vraag op dat niveau.

Naar alle warschijnijkheid heeft het relatief grotere antal arbeidsongeschikheidsadviezen mede te maken met het gegeven dat mensen met dit opleidingsniveau nogal eens werkzam zijn in zeer stresserende middenkaderfuncties (Wiersma, 1979; Reiche, 1983). Het éćn en ander impliceert dat wanneer deze mensen met psychische en/of psychosomatische klachten uitvallen zij ook daadwerkelijk arbeidsongeschikt zijn.

\section{2 (DIS) CONGRUENTIE VAN DE PSYCHOLOGISCHE ARBEIDS(ON)GESCHIKTHETDS- CLASSIFICATIES EN DE BESLISSINGEN VAN DE OPDRACHTGEVERS}

In dit onderzoek wordt van de veronderstelling uitgegaan dat de mate van (dis)congruentie tussen de verstrekte adviezen wan de psycholoog-adviseur en de beslissingen van de opdrachtgevers mede de instrumentele utiliteit van de desbetreffende psychometrische onderzoeksgegevens bepaalt.

De mate van overeenkomst wordt uitgedrukt in de vorm van het percentage congruente classificaties van arbeidsgeschikten (AG+) en arbeidsongeschiklien $(A G-)$.

De vragstellingen die daarbij als uitgangspunt dienen zijn:

- Welke arbeids(on)geschiktheidsadviezen zijn er door de psycholoog-adviseur uitgebracht?

- Welke beslissingen hebben de opdrachtgevers genomen met betrekking tot de arbeids(on)geschiktheidsbeoordelingen na kennisneming van de psychologische arviegen?

- In hoevere is er sprake van verschillen in de psychologische arbeids(on) geschiktheidsclassificaties en de beslissingen van de opdrachtgevers en wardoor kunnen deze verschillen eventueel worden verklaard?

Uit label 11 blijkt dat van de 804 verstrekte adwiezen door de psycholoogadviseur $53 \%(=426)$ van de betrokkenen als arbeidsgeschikt en $47 \%(=378)$ als arbeidsongeschikt worden beoordeeld. 
Darentegen wordt van deze 804 betrokkenen door de opdrachtgevers $27,5 \%$ arbeidsgeschikt, zijnde ongeveer de helft van de psychologische AG+-adviezen, en $72,5 \%$ arbeidsongeschikt verklaard.

label 1. Classificatiematrix van psychologisctue adviezen en besisw singen van de opdrachtgevers betreffende arbeidstongeschivtheid

\begin{tabular}{|c|c|c|c|}
\hline$\overbrace{\substack{\text { psychologisch } \\
\text { aduies }}}^{\text {beslissing }}$ & $\mathrm{ACH}$ & $\mathrm{AG}_{\mathrm{G}}$ & totad \\
\hline AGt & 27,58 & 25,$5 ;$ & 530 \\
\hline$A G^{-}$ & c & $47 x$ & $47 \%$ \\
\hline totaal & $27,5 \%$ & 72,5 & $100^{a t}$ \\
\hline
\end{tabular}

Uitgaande van de beslissingen van de opdrachtgevers als criterium, kan op grond van de classificatiematrix met betrekking tot de psychologische adviezen het volgende worden geconcludeerd:

congruent geclassificeerd: $a+d /(a+d)+(c+b) \cdot 100=74,5 / 100 \times 100=74,5 \%$.

Deze bevinding impliceert dat de psychologische adviezen en de beslissungen van de opdrachtgevers voor bijna $75 \%$ overeenkomstig zijn.

Doot middel van berekening van de kappa-coëfficient. (Fleiss, 1971) is met corrigering woor de kans op toeval, de werkelijke overeenstemming cussen de psychologische arbeids(an) geschiktheidsadviezen en de beslissingen van de opdrachtgevers bepald. Op grond van $K=4.51$ kan worden geconcludeerd dat er sprake is van een redelijke tot goede overeenkons tussen de psychologische adviezen en de beslissingen van de opdrachtgevers in dezen.

Tereinde een meer nar de adviescategorieën gedifferentiear beeld te krijgen van de verstrekte adviezen en her percentage wat darwan door de opdrachtgevers bevestigd is, $z$ in de bevindingen in dezen weergegeven in Figunir 6 . 
Figun 6: Percentubel overzicht var de deor de opdrachtgevers wel en niet overgenomen

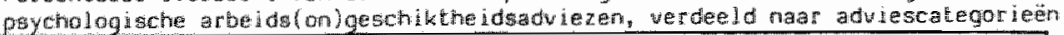

$8 X=$ door opdrachtgewers overgenomen adviezen

* door opdractitgevers niet overgenomen adviezen

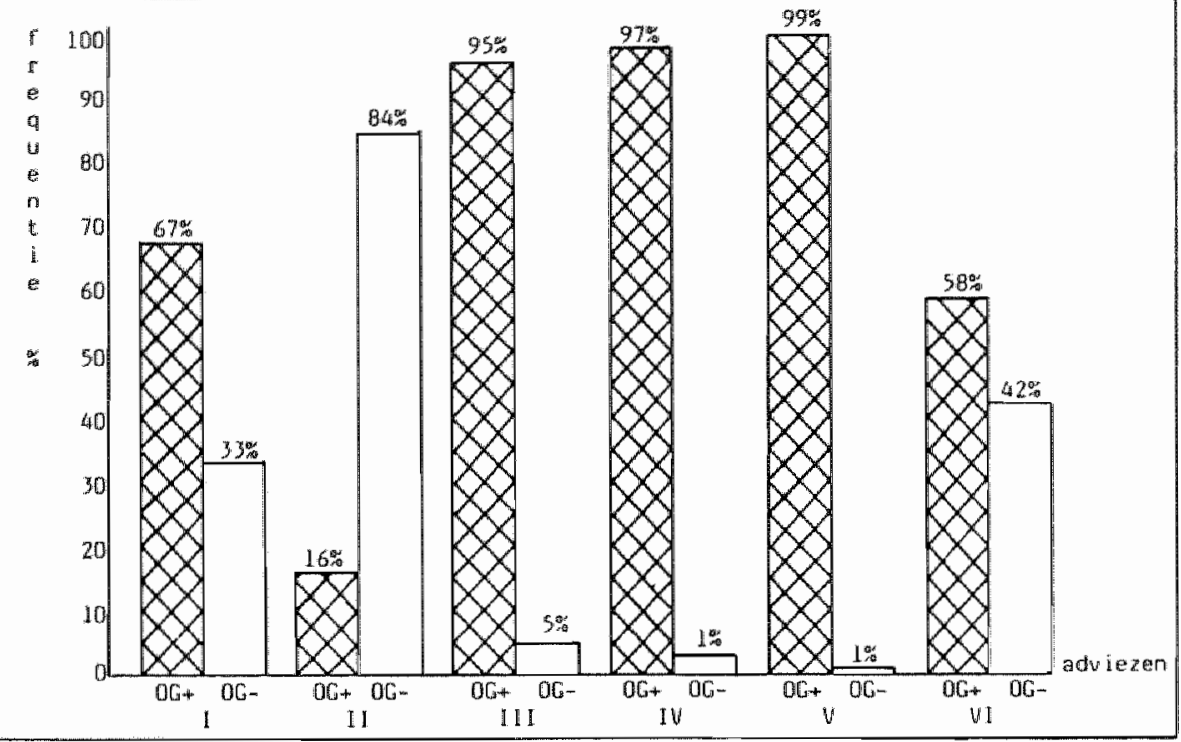

1 : geschikt ejgen/wergeli jkbarr werk

II: ongeschikt e.jgen werk/geschikt ander werk, eventuael na scholing

III: woorlopig wolledig arbeidsongegchikt

IV: blijvend angeschikt eigen werk/woorlopig ongeschikt ander werk

$V$ : volledig bli juend arbe idsangeschikt

VI : reeds geheel, gedeeltelijk en voorspelbar (blijwend) ongeschikt bij aanwang der verzeketing

Uit de histogram van figuur 6 blijkt dat verhoudingsgewijs het advies "arbe idsgeschikt voor ejgen werk" (I) voor meer dan de helft door de opdrachtgevers wotdt overgenomen $(67 \%)$. Het adwies 'arbeidsgeschikt voor ander werk" (II) blijgt in $84 \%$ van de gevallen toch te leiden tot een gehele of gedeeltelijke, mestal voorlopige, arbeidsongeschiktheidsbeslissing. In deze adviescategorte I $z$ it verreweg het grootste verschill tussen de psychologische adviezen en de bestissingen wan de opdrachtgevers.

De arbeidsongeschiktheidsadviezen in categorie III $(95 \%)$, IV (97\%) en V (99\%) bllijken vrijwel conform de beslissingen van de verzekeringsgeneeskundigen.

Met betrekking tot categarie VI blijkt dit voor meer dan de helft van de adviezen het geval te zijn $(58 \%)$. 


\subsection{Discussie}

Uit voomoende bevindingen betreffende de nate van overeenkonst tussen de psychologische arbeids(on)geschiktheidsadviezen enerzijds en de uitein delijke beslissingen van de opdrachtgevers anderzijds, blijkt dat er, ondanks een redelijk tot goede overeenkomst, bij een adntall adviescategorieën duidelijk verschillen zijn in de psychologische classificaties en de beslissingen van de opdrachtgevers.

Deze resultaten ilistreren dat bij de uiteindelije arbeids(on)geschiktheidsbeoordeling van de opdrachtgevers andere criteriagelden dan bij de psychologische arbeids(on)geschiktheidsclassificaties.

Tegen de achtergrond van de wettelijke formulering van het begrip "arbeidsongeschiktheid' kunnen ook andere, niet-psychologische factoren op de beoordeling van de opdrachtgevers van invloed zijn, zoals:

- het concrete verlies aan verdiencapaciteit, hetgeen het verschil is tussen wat betrokkene heeft verdiend en in principe nog kan verdienen (Hibbeln, 1970);

- werdiscontering van de leeftijd: de kansen om passend werk ce winden memen af naarmate men ouder is (Buys, 1984; Van 't Hullenar en Konings"veld, 1986);

- werdiscontering van de arbeidsmarktfactoren, c.q. de werkloosheid (GMD Jarverslag 1981 tot en met 1986; N.B. sinds de herziening van het sociale zekerheidsstelsel per $1-1-1987$ is dit niet meer mogelijk);

- inschatting van de arbeidsmotivatie en satisfactie van betrokkene en het daaran gerelateerde risico van een meer dan normal verhoogd verzuim bij werkhervatting (Koopman-Iwema en Wiegersma, 1985);

- vermijing van beroepszaken door de verzekeringsgeneeskundigen (Wehman, 1985), "omdat verloren beroepszaken nogal eens worden beleefd als zijn het berispingen van een tucht rechter", aldus Timmer (1988).

De discrepantie tussen het verstrekce AG+-advies en de AG-beslissing blijkt vooral betrekking te hebben op de arbeidsgeschiktheidscategorie 11 'arbeudsongeschike voor eigen of vergelijkbat werk, wel geschikt woor ander passend werk, eventueel na scholing'.

Hoewel niet expliciet onderzocht kan, gezien het scholingsbeleid zoals beschreven in de jaarverslagen van de opdrachtgevers, worden verondersteld 
dat, nast genoemde niet-medische factoren, vooral ook de mogelijkheden tot on-, her- en bijgcholing in het kader van de arbeidsongeschiktheidswetcen een rol spelen bij het niet overnemen van een AG+-advies. In de advisering AG* is namelijk ook de categorie mensen opgenomen die arbeidsongeschikt zija woor eigen werk, mat wel ander passend werk kumber verrichten, al of niet na omscholing. Het "in stat zijn tot bet volgen van scholing" is in dezen door de psycholoog-adviseur ook als een vorm van 'arbeidggeschiktheid' beschouwd, op basis van de constatering dat er voldoende psychische belastbaarheid en potentiele vermogens aenwezig zijn on scholing te volgen en daarna in principe weer an het arbeidsproces te kunnen gaan deelnemen.

Daarnaast bestat de mogelijkheid dat het advies 'gesehikt voor ander passend werk' wel degelijk door de opdrachtgever is overgenomen en door betrokkene ook gerealiseerd is, maar dat wegens een verlies aan theoretische verdiencapaciteit toch een bepald percentage arbeidsongeschiktheid is overgebleven en als zodanig door de opdrachtgevers is erkend.

of het psychologisch advies op zich is overgenomen wat betreft deze categorie kan niet uit de onderzoeksbevindingen blijken, ondat bij de analyse niet de theoretische schatting, mar alleen de beslissing van de opdrachtgevers inzake de arbeids(on)geschiktheid, uitgesplitst naar de categorieën I tot en met VI, als criterium is gehanteend.

Het één en ander illustreert dat het mogelijk is dat iemand vanuit psychologisch gezichtspunt op grond van de resterende belastbaarheid en beroepsvardigheden geschikt kan worden beschouwd wor passend werk, terwijl men. op grond wan het verlies van theoretische verdiencapaciteit toch in een bepalde categorie van arbeidsongeschiktheid wordt ingedeeld.

Met betrekking tot de discrepantie tussen het psychologisch advies en de beslissing van de opdrachtgever inzake adviescategorie vI "reeds geheel, gedeeltelijk of voorspelbaar (blijvend) arbeidsongeschikt bij aanvang der verzekering" kan het volgende worden opgenerkt.

ook het verstrekken van een dergelijk advies hoeft niet altijd te leiden tot overname door de opdrachtgevers. Ondanks voldoende aannemelijke. psychische gronden voor een arbeidsongeschiktheidsbeoordeling ten tijde 
dat betrokkene begon te werken, kunen de wetsulvoerende orgunen in hum beslissing van een dergelijk adwies afwijken.

Ingeval er sprake is van een volledige ongeschiktheid bij atrvang der verzekering, kunnen de zogenaamde "uitsluitingsartikelen" van toepassing zijn. In een dergelijke situatie is her op grond van de zogenama "discretionatre bevoegdheid' aan het desbetreffende uitwoeringsorgan in hoeverre deze artikelen ook dasdwerkelijk worden toegepast (De Jong e. a., $1984)$.

Ingeval de ABP-wec van toepassing is, mag de directie wan het ABP alleen wan deze bevoegdheid gebruik maken met goedkeuring van de Raad van Toezicht (artikel F14-3).

Deze uitsluitingsartikelen worden niet toegepast, ingeval er mogelijk wegens psychische arbeidsbelemeringen op zich wel sprake is van volledige arbeidsongeschiktheid bij aanvang der verzekering, mar er andere door slaggevende argumenten zijn wardoor betrokkene toch volgens de $2 W$, AMW, WhO en $A B P$-wet uitkeringsgerechtigd is.

Ingeval ex echter sprake is van een bij aanvang der verzekering aanwezige gedeeltelijke arbeidsongeschiktheid, is een zogenand "verplichtingsartikel" wan kracht. Dit betekent dat het uitslutingsartikel door de uitvoerende instanties moet worden toegepast wegens bet dwingendrechtelijk karakter ervan.

Tenslotte kan in dit verband worden verondersteld dat de beslissing van de verzekeringsgeneeskundige om de 'uitsluitingsartikelen' niet toe te passen beinvloed kan worden door terugkoppeling van diens ervaringen met beroepszaken inzake de toepassing van deze uitslutingsw, c.q. rísicowerende arcikelen. Met name in geval van psychische stoornissen worden de verzekeringsgeneeskundigen ofwel de uitvoerende instanties dikwijs in het ongelijk gesteld (Knepper, 1983; Hoencamp en Schipper, 1985). Dit is het gevolg van het feit dat er bij psychische stoornissen dikwijls sprake is van een discrepantie tussen de werzekeringsgeneeskundige cordeelsvorming en die van de (meestal) psychiatrische deskundigen van de beroepsinstan ties, terwijl de beroepsrechter geneigd is het standpunt van de deskundige wonder meer over te nemen (Knepper, 1983; Hoencamp en Schipper, 1985). 
Enerzijds zou dit een gevolg zijn wan de dikujls te geringe onderbouking van een "voor berop vatbare beslissing". Anderzijds zou het meer in het algemen samentangen met "de vaak onvoldoende kraliteit van de verzekeringsgeneakundige rapportage", aldus polak in zijn slotrede op de verzekeringsgeneskundige studiedagen in 1985 (Buis, 1986a).

Het is overigens uiterst discutabel om de psychiatrische beoordeling of een daarop gebaseerde uitspraak van de Rad van Beroep als kwaliteits-criterium te hanteren ten aanzien van de verzekeringsgeneskundige oordeelsvorming. De meeste psychiatrische uitspraken berusten op niet-objectief verifieerbare en onderling moeilijk vergelijkbare gegevens.

ook blijken psychiaters onderling sterk met elkaar van mening te verschillen over de arbeids(on)geschiktheid in geval wan een zelfde verzekerde (Kabela, 1988).

Bovendien stellen o.a. Nisbett en Ross (1980) en Hofstee (1981) in dit verband dat een eventuele overeensteming tussen beoordelaars niets over de jujstheid en geldigheid van hun beoordelingen zegt, zolang het, in tegenstelling tot 'gestandardiseerde beoordelingen', zogenaamde 'ongewapende beoordelingen' zijn.

Standaardisering 'wapent' de beoordelaar tegen subjectieve invlaeden welke inherent zijn an de "klinsiche beoordeling". Deze subjectieve invloeden zijn tot vandag de dag in de beoordeling van arbeidsongeschiktheid in geval van psychische stoornissen niet uitgesloten wegens het ontbreken van:

- een operationele definitie van het begrip atbeidsongeschiktheid;

- objectief-toetsbare criteria;

- een gestandardiseerd onderzoeksprotocol en een adequat. (samengesteld) gevalideerd en genormeerd meet instrumentarium.

Derhalve verkeert het "wetenschappelijk tijdperk" (Snijders, 1975) wat bem treft de psychiatrische en psychologische arbeids(on)geschiktheidsdiagnostiek nog in het beginstadium. 


\subsection{OVERZTCHT WAN HET AANTAL BEROEPSZAKEN}

Bij de inventarisatie van het aantal beroepzaken blijken relatief weinig mensen in beroep te zijn gegan tegen een mede op het psychologisch aduies gebaseerde "voor beroep vatbate beslissing".

Uit onderstaande tabel 12 valt af te lezen dat op het total van de $804 \mathrm{ar}^{-}$ beidsgeschikcheidsbeoordelingen 36 betrokkenen ( $5 \%$ ) dartegen in beroep zijn gegaan. Het betreft alleen AAW/WO-verzekerden. Daarbij gat het on 29 AG+-adwiezen en 7 AG--adviezen. Bij alle 7 gevallen van de lagtse categomie was er volgens de psycholoog-adwiseur reeds bij aavang wan de verzekering sprake van arbeidsongeschiktheid.

Tabel 12: Percentuele verdeling van in berop (act) versus niet in beroep (BC-) gegene bet rokkenen

\begin{tabular}{|c|c|c|c|}
\hline $\mathrm{C}_{\text {advios }}^{\text {bercopp }}$ & in beroep & miet in beroep & $\begin{array}{l}\text { tolate } \\
\text { anderzoeks- } \\
\text { popul the }\end{array}$ \\
\hline$A G+$ & $\begin{array}{c}n=29 \\
40\end{array}$ & $\begin{array}{c}n=397 \\
499\end{array}$ & $\begin{array}{c}7=426 \\
536\end{array}$ \\
\hline$A G^{-}$ & 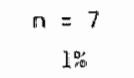 & $\begin{array}{c}n=37 \mathrm{~d} \\
466^{\circ}\end{array}$ & $\begin{array}{c}n=378 \\
477\end{array}$ \\
\hline totalal & $\begin{array}{c}n=36 \\
5\end{array}$ & $\begin{array}{c}n=768 \\
95 \%\end{array}$ & $\begin{array}{c}n=004 \\
100 \%\end{array}$ \\
\hline
\end{tabular}

\subsubsection{Discussie}

Teneinde een vergelijking te kumnen thaken tussen de onderzoeksgegevens en de landelijke gegevens wat betreft de verhouding tussen het aantal beslissingen van de uitvoeringsorganen versus het antal beroepsaken, zijn de hierover beschikbare gegevens geînventariseerd, warbij de landelijke gegevens $z$ ijn ontleend aan de jarverslagen van de GMD.

Met betrekking tot de beroepszaken beperken de gegevens over de periode 1981 tot en met 1984 (= de onderzoeksperiode) zich tot een algemeen over- 
zicht van het totale antal verstrekte arbeids(on)geschiktheidsadviezen aan de bedrijfsverenigingen en het total aatal beroepaken. In tabel 13 1 tangegeven in hoeverre de beslissingen van de bedrijfsverenigingen tot beroepsaken hebben geleid. Uitsplitsing naar bepalde biografische en ziektecategorieźn in dezen us niet mogelijk angezien de daartoe benodigde gegevens niet beschikbar zijn.

Volgens Groot Bluemink e.a. (1982) en Knepper (1984) mag evan worder uitgegaan dat ongeveer $20 \%$ wan het total antal beroepsaken betrekking heeft op de categorie "psychische stoornissen" "all spreekt recentelijk Kabela (1988) over ca. $13 \%$.

Uit tabel 13 kont nar voren dat van het total. aantal arbeids(on)geschiktheidsschatingen over de periode 1981 tot en net 1984 gemiddeld bijna $14 \%$ tot een beroepszaak heeft geleid.

Tabel 13: Owerzicht arbeidsongeschiktheidsschat ingen solo an beroepszaken in Mederland ower de periode $1901-1984$

\begin{tabular}{|c|c|c|c|}
\hline jara $\mathrm{r}$ & $\begin{array}{l}\text { arbeids (on) geschiktheids- } \\
\text { schat ingen }\end{array}$ & in beroep & niet in beroept \\
\hline 19月1 & 98.287 & 12.952 & 05.335 \\
\hline 1982 & 86.748 & 12.452 & 74.296 \\
\hline 1983 & 84.731 & 11.949 & 72.792 \\
\hline 198.4 & 84.493 & 11.772 & 72.721 \\
\hline \multirow[t]{2}{*}{ total } & 354.259 & 49.125 & $30) 5.134$ \\
\hline & $100 \%$ & $144 \%$ & $86^{\circ}$ \\
\hline
\end{tabular}

Een vergelijking tussen de landelijke cijfers en de verhouding binnen de onderzokspopulatie van het aantal beroepszaken coont, dat er binnen de onderzokspopulatie van deze studie opvallend minder beroepszaken voorkomen dan landelijk: $5 \%$ versus $14 \%$. Gezien de onderzoeksopzet mogen bier geen vergande conclusies aan worden verbonden, maar deze resultaten wijzen toch in de richting dat het gehanteerde protocol voor psychologisch onderzoek en het daarbij gebruik maken van psychometrische onderzoeksinstrumentem zijn effecten zou kumen hebben in de vorm van reductie van het aantal beroepsaken. Nader hierop gericht onderzoek zou dit kumen bevestigen of weerleggen. 


\subsection{OVERZICHT VAN DE (ON)GEGRONDUERKLARINGEN WAN WOOR BEROEP WATBARE BESLISSINGEN'}

De analyse van de gegevens omtrent het antal gegrond-" respectievelijix ongegrondverklaringen door de Raad van Beroep wan 'voor beroep vatbare besilissingen' lat zien dat van het total a antal in de onderzokspopulatie betrokken beroepszaken (36) er 6 gegrond en 30 ongegrond zijn verklaard.

Tabel 14 geeft het overzicht over de periode 1981 tot en met 1984 weer wan het aantal beroepszaken uit deze studie, vitgesplitst nat gegrond-en ongegrondverklaringen.

label 1.4: Verdeling gegrond en ongegrond werklarde beroepsaken van op psychologisch advies gebaseerde beslissingen van de opdrachtgevers

\begin{tabular}{|l|c|c|c|}
\hline jear & bercepszaken & gegrond & ongegrond \\
\hline \multirow{2}{*}{1981} & 7 & - & 7 \\
1982 & 11 & 3 & 8 \\
1983 & 9 & 2 & 7 \\
1984 & 9 & 1 & 8 \\
\cline { 2 - 3 } & 36 & 6 & 30 \\
\cline { 2 - 4 } & $100 \%$ & $16,5 \%$ & $83,5 \%$ \\
\hline
\end{tabular}

\subsubsection{Discussïe}

Ten aamien van de verhouding gegrond-en ongegrondverklaringen ven de categorie "psychische stoornissen" blijkt er op landelijk niweau sprake te zijn van een totall ander beeld dan binnen de onderzoekspopulatie: llandew lijk komen er verhoudingsgewijs meer gegrondverklaringen voor.

Terwijl in deze studie $16,5 \%$ van de beroepszaken gegrond is verklaard, geven Schipper en Hoencamp (1985) in hun evaluatie-onderzoek aan, dat in geval van psychische stoornissen meer dan $50 \%$ wan de beroepszaken gegrond wordt verklard. Kwee (1980) kwam an de hand van een dossierstudie zelfs tot meer dan 68\% gegrondverklaringen door de Raden van Beroep.

Het percentage gegrondverklaringen in deze studie $(16,5 \%)$ is wat dat 
betreft beduidend lager. Ondanks dat het hiet gat on een betrekkelijk gering antal gevallen, dat voor het geheel kwantitatief noch territoriagl representatef te achten is, wjzen deze bevindingen in de richting dat gebruikmaking van een psychologische expertise niet alleen de kans op beroepsaken kan verkleinen, maar ook die op gegrondverklaringen van dergeli illige beroepsprocedures.

Een nader, meer representatief onderzoek is overigens ook hier ter bevesthiging van deze verondergtedingen noodzakelijk.

De stelling wan knepper (1984) dat het zinloos is om als advies- en uitvoeringsorgaan, voorafgand aan de definitieve oordeelsvorming, expertise-onderzoek te laten verrichten on (het verlies van) een beroepsatk te woorkmen, wordt door deze resultaten ter discussie gesteld. Het mot dan blijkbat wel een expertisemonderzoek zijn, waarbij gebruik wordt gemakt wan theetbare 'objectiveerbare" gegevens, die alleen weerlegbatr zijn op basis van een psychometrische contra-expertise.

Bovendien mag op grond van voornoende bevindingen worden verondersteld, dat de oplossing van het 'objectiviteitsprobleem" in de oordeelsvorming bij psychodiagnostische deskundigen niet moet worden gezocht in het inschakelen wan meer dan één deskundige, zoals Kabela (1988) dat voorstelt, mat in het gebruik maken van meerbare, verifieerbate en vergelijkbare onderzoksgegevens (zi.e ook 6.5).

In aansluiting hierop heeft de andere, door Kabela (1988) aangegeven oplossing voor het objectiviteitsprobleem on de beordelend deskundige de mate van "zekerheid" van zijn conclusies aan te lacen geven wel bestaansrecht, waneer deze 'zekerheid' wordt gerelateerd aan verifieerbare psychometrigche onderzoeksbevindingen.

Deze stelling wordt onder meer onderschreven door Hofstee (1981) die als vuistregel stelt, dat "onafhankelijk van het a antal beootdelaars "ongewapende oordelen" wier keer zo willekeurig zijn als psychometrische onder zoeksbevindingen."

Uit de inhoudelijke analyse van verschillen in de gegrond en ongegrond ver$k l$ arde beroepszaken in deze studie is naar voren gekomen dat:

- 29 gevallen betrekking hebben op de adviescategorieën 1 en II 'geschikt. vook eigen en/of ander passend werk'. Alle argetekende beroepen zijn in 
dezen ongegrond verklaard. Alle betrokkenen hadden een regulier arbeidsverleden tot de datum van uitval.

- 7 gevallen betrekking hebben op de adviescategorie vi "wel arbeidsongeschikt, mar reeds (voorspelbaar) bij a anvang van de verzekering", watvan 6 gegrond en 1 ongegrond zijn verklaard. Betrokkenen hadden geen, dan wel een zeer onregelmatig arbeidsverleden.

Bij laatstgenoende 6 gegrondverklaringen is de verdaling mannen en vrouwen verhoudingsgewijs gelijk, het opleidingsniveau over de hele linie laag en de leefijic cussen de 30 en 39 jaar.

Metzelfde beeld geldt in grote lijnen ook voor de ongegrond verklaatde beroepszaken. Er zijn wat dat betreft geen verschillen geconstateerd in de biografische gegevens tussen de categorie mensen van wie het beroep gegrond, respectievelijk ongegrond is verklaard. Dat de gegrond- en ongegrondverklaringen niet door biografische en/of matschappelijke factoren worden bepald, is eveneens de conclusie van kwee (1980) naar aanleiding van zijn onderzoek betreffende beroepszaken AAW/WAO. "Verschillen in gegrond- en ongegrondverklaringen kunnen grotendeels worden begrepen uit de 'variabiliteit" die er blijkbaar mogelijk is im uitspraken van de adviserende deskundigen omtrent arbeids(on)geschikcheid op psychische gronden', aldus kwee (1980).

Timmer (1988) acht het moment van retrospectief onderzoek per definitie een structurele zwakheid van iedere beroepsprocedure, omdat in vrijwel alle gevallen een dergelijk onderzoek geruime tijd na de zagenaamde 'litigieuse' datum platsvindt. Dit is de datum warop de oordeelsvorming over de arbeids(on)geschiktheid betrekking heeft en die in de beroepsprocedure central stat.

Deze problematiek blijkt in thet bijzonder ara de orde te zijn bij retrospectief ondergok, gericht op beantwording van de vraag of een witsluitingsartikel varu toepassing zou kunnen zijn.

Een arbeids(on)geschiktheidsonderzoek, gericht op het beantwoorden van de vraagstelling of één der wettelijke uitsluitingsartikelen van toepassing is, c.q. de vraag aan de orde is of betrokkene wel of niet reeds bij anvang van de werkzamheden gedeeltelijk of geheel arbeidsongeschikt was, vindt achteraf plats. Ten tijde wan een dergelijk retrospectief onderzoek 
kan betrokkene in en andere condicie verketen dan daarvoor, terwil ar toch retrograad een uitspraxk sordt verwacht over iemands psychische toestand in het verleden. Uitspraken in dezen zijn grotendeels gebaseerd op 'achteraf-redenaties", warbij de adwiseur in belangrijke mate athankeli jk is van hetgen betrokkene over zichzelf achteraf rapporteert. Ervan uitBaande dat deze 'te goeder trouw' is, blijft het een praktisch probleem dat de belangen van betrokkene het verslag omtrent zijn eigen gesteldheid in het verleden kunnen vertekenen.

objectieve verificatie door middel van psychometrisch onderzoek is in dergelijke situaries vrijwel onmogelijk, ondat er conclusies moeten worden getrokken op basis wan retrospectief onderzoek en ex meestal geen psychometrische onderzoeksbevindingen van de periode warin betrokkene is gaan werken woorhanden zijn.

Kabela (1988) stelt in dit verband "dat het voor de psychiater, zelfs na een adequat psychiatrisch onderzoek, witermate moeilijk is een antwoord op dergelijke vragstellingen te geven." Hij veronderstelt, "dat het niet witgesloten moet worden geacht dat de meeste psychiaters zich niet goed in staat achten tot het doen wan retrograde uitspraken ontrent vermeende arbeidston)geschiktheid bij aanvang der verzekering, maar daaromtrent toch een uitspraak doen."

In de praktijk blijkt dat, ook waneer betrokkene het na een psychologisch onderzoek in eerste instantie eens is met het advies 'reeds bij aanvang van de verzekering arbeidsongeschikt', deze hier later nogal eens in de vorm van een beroepszaak op terugkomt. Bij overname van een arbeidsongeschiktheidsoordeel met betrekking rot het moment van aanvang der verzekering door de opdrachtgevers is er dikwijls geen recht op een arbeidsongeschiktheidsuitkering. Dit is overigens gezien de reacties in de dagelijkse praktijk niet algemeen bekend en zou well eens op onvoldoende voorlichting kunnen berusten.

In een becoepsaak wordt er meestal een contra-expertise verricht door een (vaste) deskundige van de Raad van Beroep, warbij de betrokken deskundige eveneens met genoende problematiek van "beoordeling achteraf" wordt geconfronteerd. Daarbij kan de betrokkene echter zijn informatie in de vorm van auto-anamestische zel frapportage 'anders gekleurd' geven dan hij of zij 
in eerste instantie heeft gedaan bij eerder onderzok, met name ingeval de resultaten darwan wor hem of haar 'negatief waren.

De latste arbeidscongeschiktheidsbeoordeling in het kader van de beroepszaak vormt meestal een belangrijke basis voor de witeindelijke uitsprak wan de Rad van Beroep ten amzien van het gegrond, dan wel ongegtond verklaren van het desbetreffende beroep. In het onderzoek van knepper (1984) bleek $90 \%$ van de rechterlijk gegrondverklaringen en meer dan $70 \%$ van de ongegrondverklaringen te berusten op de latust verrichte expercise. op basis daarvan concludeert knepper dat de beoordeling van de deskundige van de Raad van Beroep kennelijk een doorslaggevende rol in de rechterlijke besluitvorming speelt. Ook Hoencamp en Schipper (1985) komen in hun evaluatie-onderzaek van psychiatrische expertises voor de Rad van Beroep te Den Haag tot dezelfde conclusie.

Wiet alleen hebben de beroepsinstanties in dezen altijd het latste woord, maar zij blijken zich dus overwegend te baseren op de laatste witspraak van deskundige anderen, zonder dat er, woor zover bekend, ooit een empirisch onderzoek nar de redenen daarvoar heeft plaatsgevonden.

De geringe inter-beoordelaars betrouwbarheid in psychiatrische uitspraken omtrent arbeids(on)geschiktheid, zoals recentelijk door Kabela (1988) is geconstateerd, zou een dergelijk onderzoek zeker rechtvaardigen, ondat hiermee de 'rechtsgelijkheid' in oordeelsvorming van de Raden van Beroep direct en indirect ter discussie is komen te staar.

Alle 36 in beroep gegane betrokkenen in deze studie zijn in het kader van hun beroepszaak onderzocht door één van de vaste deskundigen van de Raad wan Beroep te Harlem. (N.B. Er hebben zich binnen de onderzoekspopulatie geen gevallen van hoger beroep voorgedaan..) In 35 van de gevallen was deze deskundige een psychiater en in één geval een peycholoog. zonder hieraan vergaande conclusies te kunnen verbinden, is het vermeldensward dat wan de 7 gevallen die in beroep ijn gegan tegen de uitsprak 'reeds arbeidsongeschikt bij aanvang der verzekering" de 6 gegrondverklaringen van dit. beroep door een psychiater waren onderzoch en de ongegrondverklaring was. afgegeven nadat betrokkene was onderzocht door een psycholoog. De betrokken (adviserend) psycholoog wan de Raad van Beroep had dezelfde onderzoeksinstrumenten gebruikt als de psycholoog-adviseur. Daardoor waren de onderzoeksbevindingen vergelijkbar en de daarop gebaseerde retrograde 
conclusie, argumentatie en mot ivatie van de psychologische beoordeling in ieder geval verifieerbar.

Uit een telefonisch gehouden enquête is tabel 15 samengestela, warin de antillen pgychiaters en psychologen die in het kader van beroepsaken in Nederland regelmatig worden ingeschakeld, staan weergegeven. Het verschil tussen het antal psychiaters en psychologen, die in dezen worden geconsulceerd, is verbazend groot.

Tabel 15: Owerzicht van het aantal psychiaters en psychologen als advigeurg van de Raden war Beroep in Neder land

\begin{tabular}{|c|c|c|c|}
\hline $\begin{array}{l}\text { Raden ven Beroep en } \\
\text { Anbtenarengerechten }\end{array}$ & paychiaters & psychologen & $\begin{array}{l}\text { totaal aantal } \\
\text { adviseurs }\end{array}$ \\
\hline Amste edam & 10 & - & 10 \\
\hline Arroben & $B$ & - & 8 \\
\hline Den Hoag: & 7 & - & 7 \\
\hline Hran ingen & 7 & - & 7 \\
\hline Hartem & 10 & 1 & $1 \Perp$ \\
\hline "g-Hertogenbogch & lil & - & 111 \\
\hline Roemond & 13 & 1 & 14 \\
\hline Rotterdan & 9 & - & 9 \\
\hline Whrecht & 7 & - & 7 \\
\hline Zuollie & 10 & 1 & $1 H$ \\
\hline Centrale Raad war & & & \\
\hline Beroep utrecht & 30 & - & 30 \\
\hline totian 1 & 122 & 3 & 125 \\
\hline
\end{tabular}

U.t tabel. 15 blijkt dat er in het total door de Centrale Raad van Beroep, de Raden van Beroep en de Ambtenarengerechten, 125 deskundigen als adviseur regelmatig worden geconsulteerd*. Daarvan zijn er 122 psychiater en 3 psycholoog. Er wordt overigens landelijk wel indirect van meer psychologen gebruik gernakt, maat dan altijd als adviseur van de psychiater cpersoonlijke mededeling van E. Heemsergen, secretaris van de Centrale Raad van

* Mer dank voor de medemerking aan mr. A.D.M. Mermemaeker, voorzicter van de Rad van Beroep te Roterdat, en de secretariatsmedewerkers van de andere Raden van beroep in Nederland. 
Beroep te Utrecht). Hoeveel psychologen er in dat verband worden geconsulteerd, is niet exact bekend.

Houben (1984), in leven voorzitter wan de Rabd van Beroep re Roermond, heeft een pleidooi gehouden voor de stelling dat op grond van hun psychometrische onderzoeksmogelijkheden psychologen veel meer bij beroepszaken zouden moeten worden ingeschakeld. Houben stelde dat juist met betrekking tot het 'grijze" gebied van de lichtere psychopathologie psychologisch onderzoek een uitkomst kan bieden. Enerzijds ter aanwulling op, dan wel vervanging van een psychiatrisch onderzoek, om op een zo objectief mogelijke wijze vast te stellen in hoeverre psychische stoornissen ook daadwerkelijk beperkingen in psychische belastbarheid en beroepsvaardigheden teweegbrengen. Anderzijds om vast te stellen in hoeverre de desbetreffende werkinhoud en -orastandigheden, gegeven de psychische belastbaatheid en beroepsvardigheden van betrokkene, voor deze een onmiskenbare overbelasting betekenen en tot (verdere) schade van diens gezondheid kunnen leiden.

Genoemde bevindingen betreffende de beroepszaken binnen de onderzoekspopulatie van deze studie steunen de stelling van Houben om meer psychologen bij beroepszaken te betrekken dan cot heden in Nederland het geval is.

\subsection{PREDTCTEEV WAARDE VAN DE ENRELVOUDIGE PSYCHOLOGISCHE PERSOONS- KENMERKEN MET BETRERKING TOT DE PSYCHOLOGISCHE ARBETDS(ON)GESCHIKT- HETDSCLASSIFICATIES}

Wij dit onderzok naar de relatie tussen psychologische persoonskenmerken en de psychologische arbeids(on)geschiktheidsclassificaties is gebruik gemakkt van reeds bestaande psychometrische onderzoeksmethoden (zie 5.4) en zes in de praktijk gebruikelijke categorieën van arbetds(on) geschikcheid (zine 4.3 .4 en 6.1 ).

op grond van de doelstelling van het onderzoek, het op basis van psychometrische onderzoeksgegevens kunnen voorspellen van de categorieën arbeidsgeschikten versus arbeidsongeschikten, zijn de zes adviescategorieën gereduceerd tot een dichotome indeling: arbeidsgeschikt ( $A G^{*}$ ) versus arbeidsongeschikt ( $A G^{-}$). 
Bij vergelijking van de psychologische persoonskenterken gat het on het woorspellend vermogen van deze meetbare gegevens met betrekking tot de criterium variabele, de psychologische classificatie: arbeidsgeschikt $(\mathrm{AG}+)$ versus arbeidsongeschikt (AG-).

In dit onderzoek wordc verondersteld dat ex een verschil is in psychologische persoonskenmerken (verklarende variabelen), zoals gemeten door de gehanted rde onderzoeksinstrumenten, van mensen die respectievelijk arbeidsgeschik (AG+) en arbeidsongeschikt (AG-) zijn geclassiticeerd door de psycholoog-advíseur.

De vraagstelling daarbij is: In welke psychologische persoonskenmerken verschillen respondenten die door de psycholoog-adviseur als arbeidsgeschikt $(A G+)$ worden geclassificeerd wan hen die als arbeidsongeschikt ( $A G-$ ) worden geclassificeerd?

Teneinde na te gaan of de desbetrefende variabelen op univariaat niveau een voorspellend vermogen hebben met betrekking tot de adviescategorieen $A G+$ en $A G^{-}$, heet er op grond van het exploratieve karakter van dit onderzoek een tweezijdige t-toetsing (Spitz, 1965) plaatsgevonden.

In dit onderzoek wordt de significantiegrens van $\mathrm{p}=0.05$ gehanteerd. Voorts zijn de statistische bewerkingen en analyses van de psychometrusche onderzoeksbevindingen gedaan op de zogenaamde "ruwe scores" "dit wegens het gegeven dat in de onderzoekspopulatie verschillende normgroepen naar geslacht, leeftijd en oplejdingsniveau aanezig zijn en in dit geval 'normscores" een herschaling van de ruwe scores zijn, dat wil zeggen niet met elkar vergeleken mogen worden.

In Label 16 stan de resultaten van de t-toets betreflende de samenhang tussen de psychologische persoonskenmerken enerzijds en de psychologische clasificatie arbeidsgeschike ( $A G+$ ) versus arbeidsongeschikt ( $\mathrm{AG}^{-}$) ander2. i.j. $\mathrm{d}$.

Met betrekling tot de biografische gegevens blijkt uit tabel 16 dat door de psycholoog-adviseur significant meer mannen dan wrouwen als arbeidsgeschilk worden geclassificeerd. Ook de leeftijd blijkt op univariaat niveau een rol te spelen in de psychologische arbeids(on)geschikcheidsbeoordeling. in die zan dat relatief oudere mensen significant meer het advies arbeidsongeschikt krijgen dan jongere. 
Wat betreft het opleidingsniveau blijkt er geen significant verschil tussen de psychologische beoordelingen arbeidsgeschikt versus arbeidsongeschikt.

Tabel 16: Gemiddel ten en t-toetsbevindingen betreffende psychologische pe:soonskerwerken en psychologische classificatie: arbeidsgeschikt ( $\mathrm{AC}$-) versus arbelosongeschikt $(\mathrm{AG}-)$

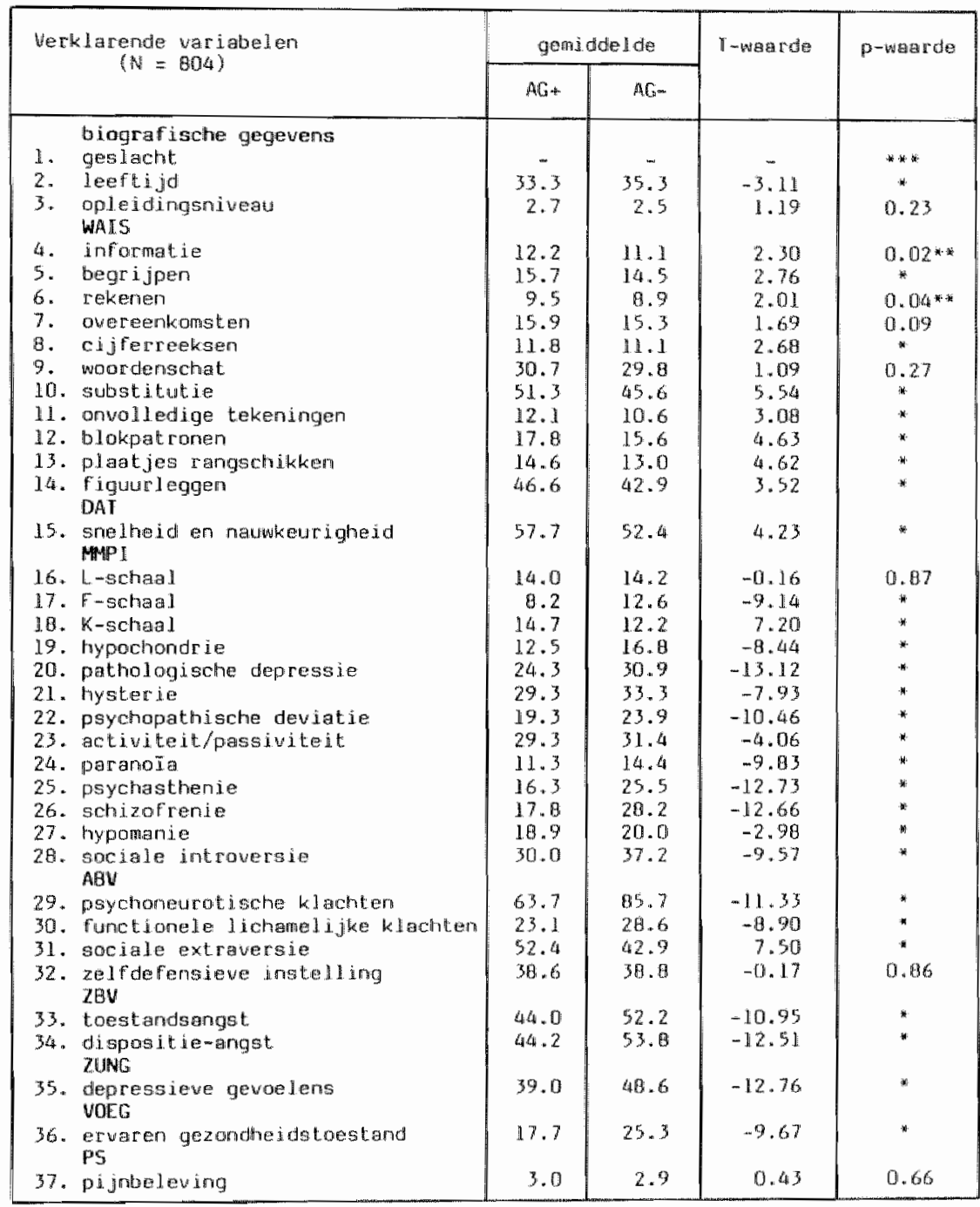

$* \quad \mathrm{p}<0.01$

* $: 0.05$

* : : mernen-vrouwen ch12 $=5.42, \rho=0.02$ 
Het byerzicht van de psychologische persoonskenmerken in tabel 16 geet voor 29 wan de $34(=85 \%$ variabejen stetn aan de oorspronkelijk geboen poychologigche beoordelingscriteria, als zijnde de variabelen met een woorspellende warde met betrekking tot de criterium-wariabele AG+ en $A G-$. Bij de twexijdige t-toetsing wordt deze steun overigens niet verkegen voor de beoordelingscriteria overeenkomsten (abstractievermogen) en woordenschat (woordenkentis), cerwijl dit bijeen significantiegrens van $p<$ 0.01 ook geldt voor informatie (algemene ontwikkeling) en rekener (rekeninzicht). De bevindingen wijzen in de richting dat met name de verbale inteligentiefactoren, met uitzondering van begrijpen (begrapsvermogen) en cijferreeksen (concentratie en geheugen), een gering tot onwoldoende voorspellend vermogen hebben met betrekking tot de criterium variabele AGt en $A G-$.

Ook wen anzien van de mate warin mensen geneigd zijn zich in meer at mindere mate social wenselijk te presenceren (L-schaal), wel of niet defensief zijn ten aanzien van hun gevoelens en subjectieve pijnklachten hebben, is geen wezenlijke invloed op de beoordeling van de psycholoog-adviseur aancoonbar. Dit blijkt daarentegen wel het geval bij duidelijk verhoogde psychische labiliteitsscores en de mogelijk daarmee samenhangende beperkingen in performale vermogens.

Wegens het verschil in inhoudelijke interpretatie van de activiteit/passiviteitschaal van de MMPI voor vrouwen en nannen (zie bijlage $c$ ) heef er een gespecificeerde analyse plaatsgevonden van deze variabele, uitgewerke naar geslacht.

Bij tweezijdige t-toetsing blijkt er bij mannen wel een significant verschil ce zijn, in ale zin dat de gemiddelde score op deze schaal bij mannen die arbeidsongeschikt worden geclassificeerd hoger ligt dan bij mannen die door de psycholoogadviseur als arbeidsgeschike zijn geclassificeerd $(T=-4.13 ; p=0.00)$. Mij vrouwen is dit verschil niet geconstateerd $(\mathrm{T}=0.31 ; \mathrm{p}=0.76)$.

op grond van deze gegevens mag worden geconcludeend dat deze schal in de psychologische pordeelsvorming al leen voor mannen een voorspell lende warde heeft. Passieve, omgevingsafhankejijke en (sociaal) overgevoelige mannen worden door de psycholoog-adviseur eerder als arbeidsongeschikt geclassiri- 
ceerd dan zij die een actieve, zelfscandige, dominante en strijdvardige houding hebben.

\subsubsection{Discussie}

De meeste psychologische indicatoren (85\%) blijken op univariat niveau een voorspellend vermogen te hebben. Dit ondersteunt wel de keuze wan de psychometrische onderzoeksinstrumenten van deze studie, mar op basis daarvan kunnen de onderlinge verhoudingen en het relatieve gewicht van de indicatoren thet betrekking tot de criterium-variabele AG+ en AG- echter niet cot witdrukking worden gebracht. Daarvoor moet eerst de onderliggende structur (model) van de desbetreffende indicatoren worden bepald en vervolgens daavan het voorspellend vermogen met betrekking tot de psychologische arbeids(on)geschiktheidsclassificatie worden vastgesteld.

Deze kwestie betreffende de onderliggende structur van de psychologische variabelen en de verhouding darvan in voorspellende zin tot de psychologische arbeids(on)geschiktheidsclassificatie, wordt in paragraf 6.9 nader uitgewerkt.

\subsection{PREDICTTEVE WAARDE VAN DE ENKELVOUDIGE PSYCHOLOGLSCHE PERSOONS- KENMERKEN MET BETREKRING TOT HET ADVIES-OVERNAMEBELELD VAN DE OPDRACHTGEVERS}

In dit onderzoeksgedeelte heeft een analyse plaatsgevonden van het advies-overnamebeleid van de opdrachtgevers. Daarbij is onderzocht, gegeven het psychologische advies, in hoeverte het advies-overnamebeleid kan worden verklabd ofwel woorspeld vanuit de scores van de onderzoekspopulatie op de psychometrische schalen van de desterreffende psychologische persoonskenmerken (indicatoren).

Teneüne na te garn welke specifieke psychologische persoonskenmerken ean voorspellende warde hebben met betrekking tot de categorieern warvan het advies wel wordt overgenomen en de categorieën war de opdrachtgevers contrair beslissen, heeft er door middel van een t-toets een nadere ana- 
lyse platsgevonden op de wel awergenomen (AG*) versus de niet overgenomen ( $\left.A G^{-}\right)$adviezen.

Daarbij is alleen gekeken nar de categorie mensen die door de psycholoog-adviseur als arbeidsgeschikt zijn geclassificeerd, uitgesplitst nat wel overgenomen (OG+) en niet overgenomen adviezen (OG-). Alle psychologische arbeidsongeschiktheidsadviezen blijken te zijn overgenomen, zodat de p-warde bij voorbat minimal en het significantieniveau derhalve maximal is. Alle gemeten psychologische persoonskennerken blijken dus in geval Wan arbeidsongeschiktheid met betrekking tor het beslissingsbeleid van de opdrachtgevers een voorspellende warde te hebben.

Er heefr een tweezijdige t-toetsing platsgevonden, warvan de resultaten in tabel 17 staan weergegeven.

Met betrekking tot de categorie mensen die door de psycholoog-adviseur als arbeidsgeschikt zijn geclassificeerd, kan uit tabel 17 worden geconcludeerd dat ex ten aanzien van de biografische gegevens een significant verschil is in leeftijd tussen de overgenomen AGt en de niet overgenomen AGt: het advies $A G+$ bijkt bij ouderen minder valk overgenomen te worden dan bij jongeren.

Berekend met de chi2-toets blijkt ook het geslacht van invloed te zijn, in die zin dat ten anzien van mannen minder vaak het advies AG+ wordt overgenomen dan bij wrowwen.

Mannen met een relatief hogere leeftid hebben derhalve in tweeërlei opzicht een verhoogde kans on, tegen het advies van de psycholoog-adviseur, uiteindelijk door de opdrachtgevers toch arbeidsongeschikt te worden verklaard. Het opleidingsniveaw blijkt niet significant te differentiëren cussen de categorie wel en niet door de opdrachtgevers overgenomen arbeidsgeschiktheidsadviezen.

Met betrekking tot de psychologische persoonskentserken blijkt de geneigdheid tot somatiseren, zoals bepald door verhoogde hypochondrie- en hysteriescores, significant $(p<0.05)$ te zijn ten anzien van contraire beslissingen van de opdrachtgevers.

Het aangeven vam somatoforme klachten verhoogt blijkbaar de kans on AG- te worden beschouwd door de opdrachtgevers, ook in geval van een AG+-advies. Daarnaast blijken mensen met een traag (psychomotorisch en perceptueel) 
Lempo een grotere kans te hebben op een AG-beslissing ondank een AG+-atures.

Tabel 1\%: Cemiddelden en t-toetsbewindingen betrefferde de categorid betrokktnen met het psychologisch advies arbeidsgeschikt: door de opdracht gevers owergenomem ( $\mathrm{OC}+$ ) versus miet owergenomen $\left(0 \mathrm{G}^{-}\right.$) adviezer

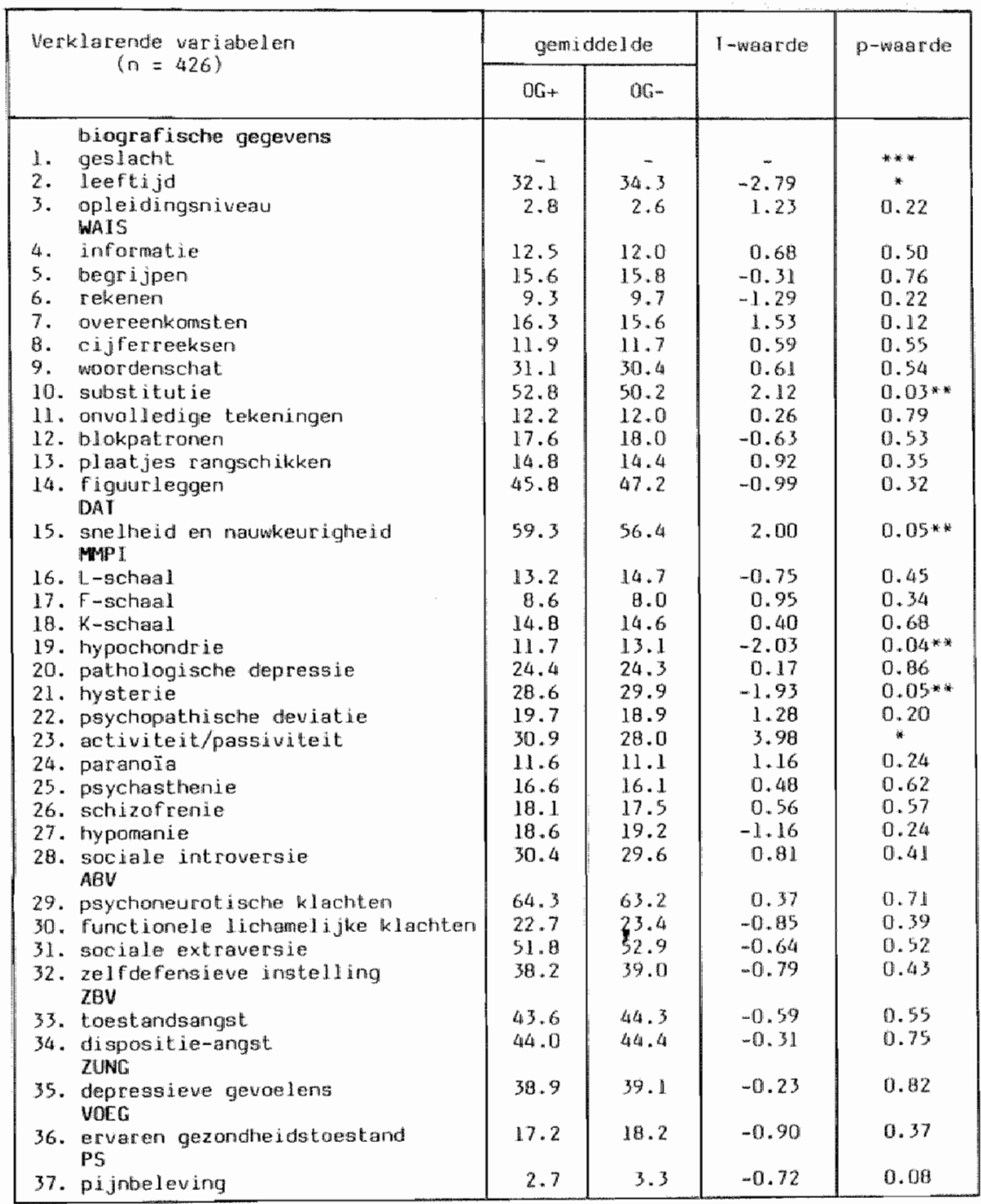

* : $\quad p<0.01$

* : $:$ P $<0.05$

* : mannen-vrouwen $\mathrm{Chiz}=19,17, \mathrm{p}=0.00$ 
Met betrekking tot het geconstateerde significante verschil in gemiddalde scores op de activiteit/passiviceitschal van de Mpl kan worden opgemerkt dat, wa de categorie mensen die op deze schal gemiddeld hoger scoort het psychologisch advies arbeidsgeschikt vaker door de opdrachtgevers wordt overgenomen dan wan de categorie mensen die gemideld lager scoren.

op grond van de verschillen in inhoudelijke interpretatie van deze activiteit/passiviceitschal nar gestacht (ziebijlage c) zou het één en ander kunnen betekenen dat ex een verschil in beoordelingsbeleid bestat bij de opdrachtgevers ten aanzien van vrouwen versus mannen. Gezien de onderzoeksgegevens worden arbeidsgeschiktheidsadviezen van respectievelijk actief ingestelde wrouwen en passief ingestelde manen in thet merendeel door de opdrachtgevers overgenomen. Een verklaring hiervoor is overigens op grond van de onderzoeksbevindingen niet te geven.

Samengevat blijken, uitgesplitst nar wel en niet door de opdrachtgevers overgenomen arbeidsgeschiktheidsadviezen, verschillen in leeftij, geslacht, somatiseren, activiteitenniveau en een lag psychomotorisch en perceptueel tempo van functioneren aanleiding te geven tot een van het psychologisch advies afwijkende beoordeling door de opdrachtgevers.

Slechts 4 wan de 34 (12\%) psychologische persoonskenmerken blijken een woorspeliend vermogen hebben, ofwel van invloed te zijn op het adviesovernamebeleid van de opdrachtgevers. Het opleidingsniveau en de overige psychologische indicatoren blijken daarentegen op univariaat niveau in dezen geen rol te spelen.

Deze bevindingen bevestigen dat andere factoren en criteria een rol spelen in de oordeelsvorming van de opdrachtgevers en wel onet name bij de categorie mensen met een psychologisch arbeidsgeschikcheidsadvies.

\subsubsection{Discussie}

Ten aanzien van de bevindingen dat het psychologisch advies AGt door de opdrachtgevers bij relatief meer vrouwen en jongeren wordt overgenomen dan bij mannen en ouderen, kam worden verondersteld dat dit het gevolg is van het feit dat in het algemeen werkende vrouwen en jongeren relatief minder verdienen dan mannen en ouderen, $0 . a$. ondat jongecen en vrouwen vaker een 
part-time functie bekleden (Central Bureau voor de Statistiek, 1984 ). Daardoor is het dikwijls gemakkelijket om op grond van resterende verdiencapaciteiten "passende" functies met een vergelijkbaar salarisniveau aan te geven. Indien er namelijk geen sprake is van een verlies van verdiencapaciteit van meer dan 15\% (AAW 25\%), is er ondanks mogelijke psychische klachten en symptomatologie geen reden voor arbeidsongeschiktheid in de zin der wet.

Bovendien wijzen Besseling en Bruinsma (1984, 1986) in dit verband tevens op de mogelíjkheid dat een normverschuiving en een verandering in wardeoordelen bij de wetsuitvoerders omtrent het verrichten van arbeid door vrouwen een rol kan spelen. Dit zou tot uiting komen in de onderzoeksbevindingen van voornoemde auteurs, namelijk dat mannen vaker dan wrouwen als (gedeeltelijk) arbeidsongeschikt worden beoordeeld, terwijl wrouwen vaker volledig hersteld worden verklaard.

\subsection{PREDICTIEVE WAARDE VAN DE ENKELVOUdIGE PSYCHOLOGISCHE PERSOONS- KENMERKEN MET BETREKKING TOT DE BEROEPSZAKEN}

In deze studie is zonder specifieke vooronderstellingen exploratief nagegaan in hoeverre er binnen de onderzoekspopulatie wat betreft de biografische en psychologische persoonskenmerkem verschillen aanwezig zijn tussen de categorie mensen die respectievelijk wel en niet in beroep zijn gegaan tegen de mede op het psychologisch advies gebaseerde beslissingen van de apdrachtgevers.

Het betrekking tot de biografische gegevens qua geslacht blijkt dat van de 534 mannen en 270 wrowwen respectieveli.jk 16 mannen en 20 vrouwen in beroep zijn gegaan, dat wil zeggen significant neer vrouwen dan mannen.

Met betrekking cot de psychologische variabelen blijkt dat slechts 3 van de 34 psychologische variabelen $(=9 \%)$ duidelijk een voorspellende warde hebben ten aanzien van de categorie mensen die respectievelijk wel en niet in beroep zijn gegaan.

Dit betreft de L-schaal van de MMPI, de activiteit/passiviteitschal van de MMPI en de pijnschaal. 
De mensen die in beroep zijn gegan scoren significant lager op deze psychometrigche wehlen dan $z i j$ die niet in beroep zijn gegaan.

Tabel 1t: Gemiddelden en t-toetsbevindingen betreffende de categorie betrokkerien dite in bervep is gegaan (BG+) vergus de categorie die niet in beroep is gegaain (Bé-)

\begin{tabular}{|c|c|c|c|c|}
\hline \multirow{2}{*}{$\begin{array}{c}\text { Verkiarende variabelan } \\
\qquad(N=94)^{4}\end{array}$} & \multicolumn{2}{|c|}{ gemiddelde } & \multirow[t]{2}{*}{ T-war dife } & \multirow[t]{2}{*}{ puwar de } \\
\hline & $\mathrm{BC}+$ & $96-$ & & \\
\hline $\begin{array}{l}\text { biograf iache gegevens } \\
\text { d. ges lacht }\end{array}$ & - & - & - & $x$ \\
\hline Z. $\quad$ leeftidd & $3 E .1$ & 34.2 & 1.22 & 0.22 \\
\hline $\begin{array}{l}\text { 3. opleidinganiverus } \\
\text { wars }\end{array}$ & 2.4 & 2.6 & -0.57 & 0.57 \\
\hline 4. informatie & 11.7 & 11.9 & $\mathbb{R} .08$ & 0.93 \\
\hline 5. begrifpen & 15.2 & 14.0 & 0.97 & 0.33 \\
\hline 6. rekenen & 9.3 & 7.0 & 1.83 & 0.06 \\
\hline 7. overenkonsten & 15.6 & 16.1 & -0.53 & 0.59 \\
\hline 6. cljferreken & 11.5 & 11.2 & 0.38 & 0.70 \\
\hline 5. woordengchat & 30.3 & 29.5 & 0.33 & 0.73 \\
\hline 10. substitute & 48.7 & 50.5 & -0.67 & 0.50 \\
\hline 11. onvoll ledige tekeningen & 11.4 & 12.1 & -0.53 & 0.59 \\
\hline 12. blokpertanen & 16.8 & 16.5 & 0.27 & 0.79 \\
\hline 13. plast jes rangach iktken & 13.8 & 14.6 & -0.82 & 0.41 \\
\hline $\begin{array}{l}\text { 14. Pigum leggen } \\
\text { DAF }\end{array}$ & 44.9 & 44.9 & 0.01 & 0.99 \\
\hline $\begin{array}{l}\text { 15. sme lhe id en ratukeurigheid } \\
\text { mip I }\end{array}$ & 55.2 & 56.3 & -0.3 .3 & 0.73 \\
\hline 16. L-schad & 13.5 & 26.8 & -2.73 & 0.01. \\
\hline 17. F-sehar 1 & 10.3 & 10.1 & 0.19 & 0.85 \\
\hline 18. $K-s c h$ aral & 13.6 & 12.5 & 1.24 & 0.21 \\
\hline 19. thypochondrie & 14.4 & 15.8 & -1.10 & 0.27 \\
\hline 20. patholagische depressie & 27.3 & 27.8 & -0.34 & 0.73 \\
\hline 21. hysterie & 31.2 & 3.3 & -0.10 & 0.92 \\
\hline 22. psychopathische deviatie & 21.4 & 20.3 & 0.97 & 0.33 \\
\hline 23. activitedtpassivileit & 30.2 & 32.1 & -2.29 & $0.02^{* * *}$ \\
\hline 24. par inoja & 12.8 & 13.2 & -0.43 & 0.66 \\
\hline 25. peychestthenie & 20.5 & 22.0 & -0.75 & 0.45 \\
\hline 26. sichizotrenie & 22.6 & 22.6 & 0.00 & 0.99 \\
\hline 27. hypomantie & 19.4 & 19.8 & -0.30 & 0.76 \\
\hline $\begin{array}{l}\text { 28. sociale introversie } \\
\text { ABN }\end{array}$ & 33.2 & 36.1 & -1.11 & 0.27 \\
\hline 29. psychoneurolische klachten & 74.1 & 69.3 & 0.95 & 0.34 \\
\hline 30. functionele lichanel i jke k lachten & 25.5 & $2 \theta .1$ & -1.66 & 0.09 \\
\hline 31. soc do de extraversie & 48.0 & 49.6 & -0.10 & 0.85 \\
\hline $\begin{array}{l}\text { 32. Zellfide funs lave instelling } \\
\text { ZBW }\end{array}$ & 38.7 & 30.9 & -0.11 & 0.91 \\
\hline 3. toegtanderangst & 47.8 & 47.8 & -0.03 & 0.97 \\
\hline $\begin{array}{l}34 . \text { di epos it ie-angst } \\
\text { ZuNo }\end{array}$ & 48.7 & 49.0 & -0.15 & 0.87 \\
\hline $\begin{array}{l}\text { 35. depresedeve gevoelens } \\
\text { worg }\end{array}$ & 43.4 & 43.6 & -0.08 & 0.93 \\
\hline $\begin{array}{l}\text { 36. Puaren gezoncthe ids toes tand } \\
\text { pg }\end{array}$ & 21.2 & 23.2 & -1.03 & 0.30 \\
\hline 37. pijntove leving & 2.9 & 4.2 & -2.31 & $0.02 *$ \\
\hline
\end{tabular}


Uitgande van de operationalisaties van de L-schaal, de activiteitpassiviteitschal en de pijnschaal. (Nutin en Beuten, 1969; Lachar, 1973; Danlstrom e.a., 1975; Greene, 1980) mag op grond van deze bevindingen worden verondersteld, dat de categorie mensen die in beroep is gegaan vergeleken met de categorie die niet in beroep is gegaan, wordt gekenmerkt door:

- meer psychische volwassenheid;

- meer reëel zelfinzicht;

- minder conventionaliteit;

- minder neurotische stoornissen;

- minder somatiseren;

- minder pijnbeleving.

Dat zowel actief ingestelde vrouwer als passief ingestelde mannen in beroep zijn gegaan, heeft nar alle warschijnlijkheid te maken met de hiervoor beschreven onderzoeksbevindingen, dat de opdrachtgevers met nane het adwies arbeidsgeschikt van deze categorie mensen overnemen en in de meeste gevallen vooral arbeidsgeschiktheidsverklaringen door betrokkenen worder aangevochten.

\subsection{Discussie}

Voomoemde bevindingen komen overeen met die van kwee (1980) en Knepper (1984), die eveneens hebben geconstateerd dat ar meer vrouwen dan mannen in beroep gaan.

Leeftijd blijkt geen verschil te kunem voorspellen tussen de categorie mensen die respectievelijk wel en niet in beroep gaan, al is er wel een tendens dat ouderen meer in beroep gan dan jongeren. Dit is in overeensteming met de bevindingen van Wehman (1985), die overigens wel een significant verschil in leeflijd heeft geconstateerd.

Wehman (1985) vond verder geen verklaring voor de verschillen tussen de in beroep en niet in beroep gegane respondenten wat betreft beroepsgroep, burgerlijke staat, gezinssamenstelling, aatal kinderen, het wel of niet: in medische behandeling/psychotherapie zijo (geweesc) en de gestelde psychische diagnose. 


\subsection{PREDLCTLUE WAAROE VAW DE ENKEL VOUDIGE PSYCHOLOGISCHE PERSOONS-}

KENMERKEY MET AETREKKING TOT DE (ON)GEGRONDVERKLARINGEN

In dit onderzok is vervolgens de vrag an de orde in hoeverre psychologische persoonskenmerken op univariat niveau een voorspellende waarde hebben met betrekking tot het onderscheid tussen mensen van wie het beroep door de rechter gegrond versus ongegrond wordt verklard.

Wegens het geringe aantal becrokkenen dat daadwerkelijk in beroep is gegaan $(n=36)$ en darmee het beperkte aantal gegrond- $(n=6)$ en angegrondverklaringen $(n=30)$ zijn de eventuele verschillen in psychologische persoonskenmerken in dezen niet zinvol en niet verantwoord statistisch coetsbar geweest.

\subsection{Discussie}

Ondat er geen statistische toetsing mogelijk was, heeft er een analyse van de gegrond versus ongegrond verklaarde 'gevallen' platsgevonden door middel van een kwallitatieve, beschrijwende exploratie.

Daarbij is een vergelijking gemakt met de landelijk bekende cijfers omtrent de verhouding tussen gegrond en ongegrond verklaarde beroepszaken bij de diagnasecategorie 'psychische stoornissen'.

Uit verschillende onderzoeken (Kwee, 1980; Knepper, 1984; Hoencamp en Schipper, 1985) is naar voren gekomen dat in geval van psychische problematiek 1 andellijk ongeveer $60 \%$ van de beroepszaken gegrond wordt verklaard, cerwijl het percentage gegrondverklaringen in deze studie op ongeveer $16 \%$ blifkt te liggen. Dat er landelijk ongeveer $40 \%$ ongegrondverklaringen platsvinden tegen de $84 \%$ die er bij de onderzoekspopulatie hebben platsgevonden, impliceent dat in deze studie tweenal zoveel ongegrondwerklaringen $z$ ijn afgegeven dan landelijk het geval is.

Deze gegevens staan overzichtelijk wergegeven in tabel 19.

vergeleken met het landelijk percentage gegrondwerklaringen over alle diagnosecategorieün (zie bijlage A) kan worden gesteld dat er wel een redelijke overeenstemming is. Landelijk worden per jaar bijna $14 \%$ van de beroepszaken gegrond verklaard (GMD Jaarverslagen 1981 tor en met 1984), terwijl dit in deze studie $16 \%$ bedragt. 
Tabell I9: Oubrzicht gegrond- an ongegrondverklaringen wan de landelijhe eng de anderzoekspopulatite

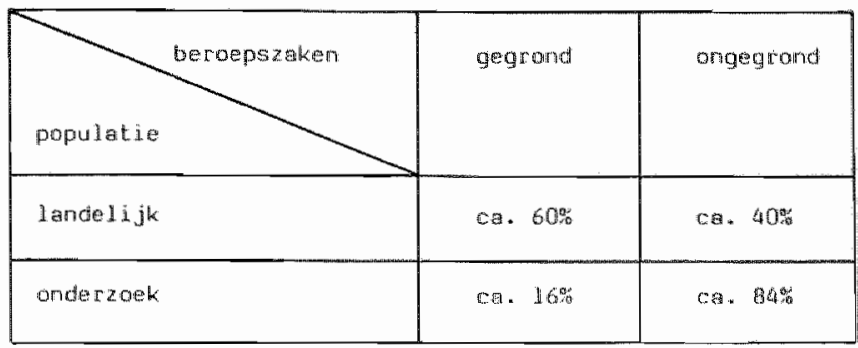

6.9 PREDICUTIEVE WAARDE VAN DE COMBINATIE VAN PSYCHOLOGTSCHE PERSOONSKENMERKEN MET BETREKKING TOT DE PSYCHOLOGISCHE ARBELDS(ON)GESCHIKTHETDSCLASSTFICATTES

Teneinde het voorspellend vermogen te kunmen bepalen van de psychologische persoonskenmerken met betrekking tot de psychologische arbeids(on)geschiktheidsclassificaties, wordt eerst de onderlinge structuur van de verklarende variabelen (predictoren) bepaald. Dat wil zeggen dat de variantie binnen het total aantal verklarende wariabelen effectiever wordt weergegeven in een beperkt aantal componenten.

Vervolgens wordt de voorspellende warde van de gevonden componenten bepald met betrekking tot de psychologische arbeids(on)geschiktheidsclassificatie arbeidsgeschikt $(\mathrm{AG}+)$ versus arbeidsongeschikt $\left(\mathrm{AC}^{-}\right)$.

Om op multivariat niveau de onderlinge structur van de werklarende varia bellen te bepalen is gebruik gemaak van de principale componenten-analyse (PCA). Deze structur levert da componenten (dimensies) op van de onderling samenhangende variabelen. Met deze techulek worden de correlaties van de variabelen met de componenten ('component-ladingen") aangegeven. Hiermee wordt een indicatie verkregen wan her belang van de variabelen met betrekking tot de gevonden componenten.

Een hoge lading betekent dat de desbetreffende variabele in sterke mate bijdragt an de betekenis van de desetreffende dimensie variabelen die hoog laden op dezelfde dimensie hangen onderling hoog samen. Een lage lading betekent dat deze variabele relatief weinig an de desbetreffende 
dimensie bijdragt. Er wordt in dit onderzoek uitgegaan van een componencenlading $>.5$ en $<-.5$.

In de principale componenten-analyse zijn de volgende subtests betrokken:

- alle subtests van de WhIS;

- de subtest snelheid en naukeurigheid van de DAT;

- alle schalen van de MMPI;

- alle schalen van de ABV;

- alle schalen van de ZBV;

- Zung-8core;

- VOEG-score;

- Pijnachaal.

De analyse levert een componentenstructuur met ach componenten met een eigenwarde > 1. Deze acht componenten tesamen verklaren $69 \%$ van de váriantie.

Na varimax-ratatie geeft de analyse een componentenladingsmatrix, zoals weergegeven in tabel 20 , warbij componentenladingen $<|.5|$ zijn verwijderd. De eigenwarden var de resulterende componenten zijn als percentage verklaarde variantice eveneens in tabel 20 opgenomen.

De eerste vijf componenten, bestaande uit 30 van de 34 variabelen ( $85 \%$ ), blijken goed interpreteerbaar. Met deze vijf dimensies wordt bijna $60 \%$ van de variantie verklaard, hetgeen voldoende is (Van Knippenberg en Siero, 1980).

De cotal verklaarde variantie en de per dimensie verklaarde variantie staan weergegeven in tabel. 20 .

De verklarende onderzoeksvariabelen laten zich redelijk representeren in een relatief eenvoudig model met, in volgorde van de mate van werklaarde variantie, de volgende vijf dimensies:

1. psycho-emot ionele labiliteit:

2. verbale intelligentie;

3. somatiseren;

4. psychopathologie;

5. performale intelingentie. 


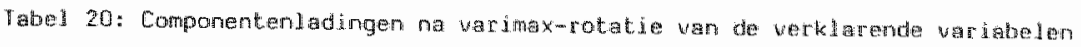

\begin{tabular}{|c|c|c|c|c|c|}
\hline wariabulen & $\begin{array}{l}\text { compo- } \\
\text { nent i } \\
\text { psycho- } \\
\text { amotio- } \\
\text { nelle } \\
\text { sabili- } \\
\text { teit }\end{array}$ & $\begin{array}{l}\text { compo- } \\
\text { nent } 2 \\
\text { verbale } \\
\text { intell i- } \\
\text { gentie }\end{array}$ & $\begin{array}{l}\text { conpo- } \\
\frac{\text { nent } 3}{\text { sontat in }} \\
\text { seren }\end{array}$ & $\begin{array}{l}\text { compo- } \\
\text { rent is } \\
\text { psycho- } \\
\text { patho- } \\
\text { logie }\end{array}$ & $\begin{array}{l}\text { compow } \\
\frac{\text { nent } 5}{\text { perfor- }} \\
\text { male } \\
\text { intel } 1 \text { i- } \\
\text { gentie }\end{array}$ \\
\hline 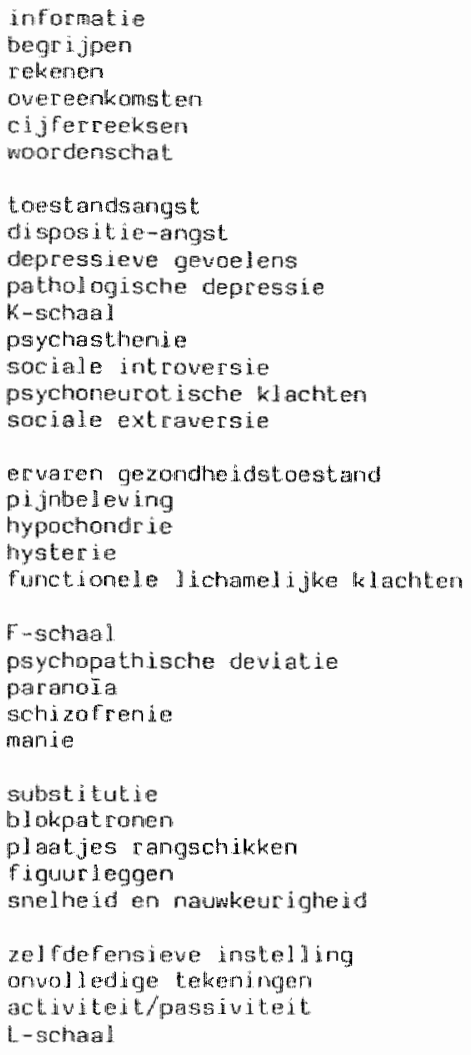 & $\begin{array}{r}0.72 \\
0.75 \\
0.71 \\
0.71 \\
-0.64 \\
0.78 \\
0.89 \\
0.71 \\
-0.76\end{array}$ & $\begin{array}{l}0.75 \\
0.79 \\
0.61 \\
0.75 \\
0.49 \\
0.84\end{array}$ & $\begin{array}{l}0.67 \\
0.54 \\
0.84 \\
0.78 \\
0.71\end{array}$ & $\begin{array}{l}0.65 \\
0.61 \\
0.59 \\
0.62 \\
0.84\end{array}$ & $\begin{array}{l}0.75 \\
0.70 \\
0.55 \\
0.72 \\
0.66\end{array}$ \\
\hline percentage verklatcde variant le & 30.1 & 1. Lif … थै & 6.1 & 4.9 & 4,0 \\
\hline $\begin{array}{l}\text { percentage lotal werklatarde } \\
\text { variantie }\end{array}$ & & & & & 59.4 \\
\hline
\end{tabular}


De eerste component prycho-emotionele labiliteit verklart $30 \%$ van de variantie en omat in volgorde var hun lading de volgende inhoudelijke variabelen, zoals weergegeven in tabel. 2 la.

Tabel 2la: Verklarende variabelen in volgorde van lading op component 1: psycho-emotionele labiliteit

\begin{tabular}{|c|c|}
\hline werpharende wariabejen & componentenladingen \\
\hline sacial in antrowerese & .88 \\
\hline porychagthenie & .79 \\
\hline aociale extraversie & -.76 \\
\hline dioponsilie-angst & .75 \\
\hline toestiandrangat & .72 \\
\hline pethologische depressie & .71 \\
\hline psycthoneur at ische kiachten & .71 \\
\hline depreselieva gevoedens & .71 \\
\hline Schizofrenie & .65 \\
\hline Correctieschad & -64 \\
\hline
\end{tabular}

De twede component verklaart bijna $14,5 \%$ van de variantie en kan worden benoend a $^{\mathrm{s}}$ verbale intelligentie, gezien de samenstelling uit alle verbale WaIS-subtests, zoals weergegeven in tabel. $2 \mathrm{lb}$.

Tabel 21b: Verklarende variabelen in valgorde wan lading op component 2: verbale intelligentie

\begin{tabular}{|c|c|}
\hline verkl trende var itabelen & componenten ladi ngen \\
\hline wotrdenschat: & .84 \\
\hline begri i jpen & .79 \\
\hline overeankonisten & .75 \\
\hline informatid & .75 \\
\hline rekener & .61 \\
\hline hoijferemen & $.49)$ \\
\hline
\end{tabular}

De derde component verklaart $6 \%$ van de variantie en kan worden beschreven als somatiseren. 
De desbetreffende variabelen $z$ ijn in volgorde wan hu lading weergegeven in tabel $2 \mathbb{C}$.

Tabel 2lc: Verklarende wariabelen in wolgordo wan lading op component 3: somat iseren

\begin{tabular}{|l|c|}
\hline Werklarende variabelen & conponentenladinger \\
\hline hypochondrie & .84 \\
hysterie & .78 \\
Functionele lichamelijke klachten & .71 \\
ervaren gezondheiostoestand & .67 \\
Pijnbeleving & .55 \\
\hline
\end{tabular}

De vierde component verklaart bijna $5 \%$ van de variantie en kan worden betiteld als psychopathologie, gezien de. inhoud van de variabelen, welke in volgorde van hun lading in tabel $21 d$ stan weergegeven.

Tabel 2ld: Verklarende variabelen in wolgorde van lading op component 4: psychopathollogie

\begin{tabular}{|l|c|}
\hline werklarende wariabelien & componentenladingen \\
\hline marie & .84 \\
F-schaal & .65 \\
schizofrenie & .62 \\
psychopathische dewiatie & .61 \\
paranoía & .59 \\
\hline
\end{tabular}

De vijfde component, $4 \%$ van de variantie verklarend, heeft gezien de samen stell lende variabelen, zoals weergegeven in tabel 2 le, betrekking op het praktisch handelend denken. Her betreft de performale WAIS-subtests, zij het minus die betreffende het kritisch warnemingsvermogen, en voorts de DAT-subtest snelheid en naukeurigheid. Op grond van deze samenstelling kan de vijfde component als volgt worden benoemd; performale incelligentie. 
Tabel 2le: Werklarende variabelen in wolgorde var lading op component 5 : performa le intell 1 igent is

\begin{tabular}{|c|c|}
\hline werklatende variabelen & componemenladirgen \\
\hline subetitutie & .73 \\
\hline figubir leggen & .72 \\
\hline blokpat ronen & .70 \\
\hline 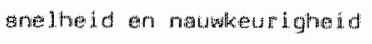 & .66 \\
\hline plat jes rangeshikken & .55 \\
\hline
\end{tabular}

Om de voorspellende warde van de vijf componenten ten aanzien van de psychologische arbeids(ongeschiktheidsclassificatie te bepalen, is er per alzonderlijke component een tweezjjige t-toetsing uitgevoerd.

De gemiddelden van de variabelen van de desbetreffende componentem en de t-toetsbevindingen, werdeeld naar de psychologische classificatie AG* versus $A G^{-}$, staan weergegeven in tabel 22 .

Tabel 22: Gemiddelon wan de wariabelen van de componentern en t-toetsbewindingen, werdeeld nam de psychologische classificatie: arbe idsgeschikt (AG+) versus arbeidsongesichikt ( $A C_{-}$)

\begin{tabular}{|c|c|c|c|c|}
\hline \multirow[t]{2}{*}{ Componenten } & \multicolumn{2}{|c|}{ gemidde J de } & \multirow[t]{2}{*}{ T-waarde } & \multirow[t]{2}{*}{$p-$ watade } \\
\hline & $\mathrm{AC}+$ & AG- & & \\
\hline poscha-emotionele labiliteit & 0.38 & 0.43 & -11.00 & $*$ \\
\hline verbale intel ligervien & -0.01 & 0.01 & -0.27 & 0.79 \\
\hline somg ti serer & -0.15 & 0.17 & -4.07 & * \\
\hline psychopethalogit & -0.12 & 0.13 & -3.24 & $*$ \\
\hline performese inted igentic & -0.119 & -0.21 & 4.94 & $*$ \\
\hline
\end{tabular}

* : p $<0.01$ bij tweezijdigo loetsing

Uit tabel 22 blijkt dat er en significant verschil bestat tussen de psychologische classificatie arbeidsgeschikt versus arbeidsongeschikt. Bij de arbeidsongeschikt geclassificeerden is er sprake van een verhoogde mate van psychomemotionele labiliteit, somatiseren en psychopathologie, terwijl bij deze categorie de performale intelligentie significant lager is dan bij de arbeidsgeschikten. Als zodan h bebben deze vier verklarende 
componenten een voorspellende warde ten aanzien van de psychologische beoordeling $A G^{*} / \mathrm{AG}^{-}$.

Deze onderzoeksbevindingen geven steun aan de opvatting dat met psychometrische tests, screenings- en persoonlijkheidsuragenlijsten een antal onafhankelijke psychologische dimensies gemeten kunnen worden (Luteijn, $1985)$.

De invariante hoofddimensies, zoals gevonden in dit onderzoek, ontenen in dezen hun warde aan de mate warin zijeen voorspellende warde blijken te hebben ten a anzien van het classificeren van de categoriean arbeidsgeschikten versus axbeidsongeschikten. Ter bepaling van het relatieve gewicht van de samengestelde componenten met betrekking tot de arbeids(on)geschiktheidsclassificatie is er een regressie-analyse over de componentenscores gedara (Kleinbaum e.a., 1882 ).

Een regressie-analyse geeft een beeld van de mate wan beinvloeding van de verklarende variabelen op de criterium-variabele. Een regressie-analyse beantwoordt de vraag: In hoeverre is de criterium-variabele arbeidsgeschikt $(\mathrm{AG}+)$ versus arbeidsongeschikt $\left(\mathrm{AG}^{-}\right)$te voorspellen uit een aantal predictor-variabelen?

De analyse-resultaten worden uitgedrukt in zogenaande regressiegewichten. Een regressiegewicht geeft aan hoeveel voorspellende warde een verklam rende variabele heeft met betrekking tot de criterium-variabele, nadat er rekening is gehouden met de voorspellende bijdrage van de overige variabelen

In dit onderzoek bestat de criterium-variabele wit twee categorieën, te weten AGt- en $A G--c l a s s i f i c a t i e s$. De classificaties omtrent de arbeids(on)geschiktheid zijn mede tot stand gekomen op basis van psychomertache onderzoeksgegevens.

Voor meer inzicht in de voorspellende warde wan de psychometrische onderzoeksgegevens dient de vraag beantwoord te worden: Welke factoren blijken van doorslaggevende betekenis te zijn voor de psychologische arbeids(on) geschiktheidsclassificaties?

onderzoekstechnisch heeft deze vraggstelling betrekking op enerzijds een dichotome criterium-variabele (arbeidsgeschikt af arbeidsongeschikt) en 
anderzijds een groot antal werklarende (potemieel-woorspellende) variabelen.

De eerste analyserende stap betreft de reducering van de potentiele predictoren. Door middel van componenten-analyse is de groep van 34 psychologische variabelen (zhe tabel 20 ) tot vijf factoren gereduceerd, te weten psycho-emotionele labiliteit, verbale inteligentie, somatiseren, psychopathologie en performale intelligentie (zie tabel 2 la tot en met 2 le).

Mls potentiael belangrijke biografische predictoren zijn gekozen: Leeftijd, geslacht en opleidingsniveau.

De oorspronkelijke vraagstelling kan nu gereduceerd worden tot: In hoeverre zijn deze acht variabelen adequate voorspellers voor de psychologische arbeids(on)geschiktheidsclassificatie en hoe sterk is de voorspellende warde wan elk daarvan?

Tabel 23: Het uiteindelijke resul tat van stapsgewijze logistigche regressie-analyse met als criter jum-variabele de psychologische arbejosongeschiktheidsclassificatie en de predictor-wariabelen

\begin{tabular}{|c|c|c|c|c|c|c|}
\hline Predictor-variabelen & $\begin{array}{l}\text { regressile- } \\
\text { caëfricient. }\end{array}$ & $\begin{array}{l}\text { standard } \\
\text { error }\end{array}$ & I-warde & Chi-square & DF & $p$ \\
\hline Constante & .16 & .10 & 1.71 & & & \\
\hline Psycho-emotionele labilitejt & 1.05 & .11 & $9.66 *$ & $108.30^{*}$ & $\mathbb{1}$ & .00 \\
\hline Sonatiseren & .42 & .09 & $4.42^{*}$ & $28.68 *$ & 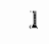 & .00 \\
\hline Psychopathol ogie & .34 & .10 & $3.57 *$ & $20.04 *$ & 1 & .00 \\
\hline Performale intelligentie & -.53 & .10 & $5.31 *$ & $13.19 \%$ & $\Downarrow$ & .00 \\
\hline Opleidingsniwean & - & - & - & 8.90 & 6 & .18 \\
\hline Leeftij.jd & - & - & - & .47 & $\Downarrow$ & .49 \\
\hline Werbale intejligentie & - & - & - & .15 & $\Downarrow$ & .70 \\
\hline Cosbatat. & a. & - & - & .11 & $\Perp$ & .74 \\
\hline
\end{tabular}

Coodneste of fit:

* Hostier Chi-squere $=11.24, D F=9, p=180$

* Brown Chi-gquare $=4.03$, of $=2, p=.133$

- Betekent dat BMDP geen coëfficiënten levert bowen het significantieniveau wan $p=0.05$.

* De afzonderlijke predictor-effecten kinnen zowel met de univariate i-waarde als mek de Chi-square getoetst worden. De Jogistische regressiecoëfriciënten behorende bij de met. sterret.jes gemerkte toetsingsgrootheden zijn bij tweezijdige toetsing significant ( $p<0.05$-niveau).

* De Hosmer en Brown Chi-square-waerden geven aan dat het gewonden model overeenkomt met de geobserveerde data, in die zin dat njet-significante waarden verwijzen naar adequastheld van het model. 
Tabel 23 geeft de witeindelijke resultaten weer, verkxegen door midel wan de stapsgewijze logistische regressieprocedure wan het stat istische standaardpakket Bio-Medical Statistical Data program (BMDP, 1981).

Deze regressie-analyse is toegepast op de variabelen: leeftijd, geslacht, opleidingsniveau, psychomemotionele labiliteit, psychopathologie, wewale intelligentie en performale intelligentie.

Uit tabel $23 \mathrm{kan}$ worden geconcludeerd dat de benadering van de geselecteerde componenten door middel van een logistische regressie-analyse antoont dat de predictieve variabelen zich goed laten representeren door een lagdimensionele structur: alleen psycho-emotionele labiliteit, somatiseren, psychopathologie en performale intelligentie bijiken de psychologische arbeids(on)geschiktheidsclassificaties te beanvloeden.

ondat deze paychologische dimensies weergegeven worden door componentenscores en wel in de vorm van gestandardiseerde variabelen (gemiddelde = 0 en standaarddeviatie $=1$, kunmen de logistische regressiecoëficienten worden beschouwd als onderling vergelijkbare kwantitatieve uitdrukkingen van de sterkte van de diverse effecten.

Aldus blijkt dat 'psycho-motionele labiliteit' de psychologische arbeids(on)geschiktheidsclassificatie praktisch tweemal zo sterk beînvloedt als de performale intelligentie en dat deze latste factor op zijn beurt weer een sterkere invloed heeft op de classificaties dan somatiseren en psychopathologie.

Teneinde de kwantitatieve warde van de sterkte wan de beinvloedingsrelatie van de predictoren op de criterium-variabele aan te kunnen geven, zijn de odds-ratio's berekend (Schlesselman, 1982).

Tabe 24: De odfs-ratio's van de relevante predictoron an de overeenkonst anet 95 ; bet rouwbarme idsinterwallan.

\begin{tabular}{|l|c|c|}
\hline Predictoren & odds-ratio': & $95 \%$ C. 1. \\
\hline Psycho-emotionele labiliteit & 2.86 & $(2.31 ; 3.53)$ \\
Somatisering & 1.51 & $(1.26 ; 1.82)$ \\
Psychopathologie & 1.41 & $(1.17 ; 1.69)$ \\
Performale intelligentie & .59 & $(.46 ; .71)$ \\
\hline
\end{tabular}


In tabel 24 worden de gestandardiseerde odds-tatio's wan alle relewante predictoren met de owereenkonstige $95 \%$ betroubaarneidsintervallen gegeven.

Bij een unit-stijging van één standaarddeviatie (in dit geval een toename van 1) in psycho-emotionele labiliteit stijgt de conditionele kansverhouding van de arbeidsongeschiktheidsclassificatie versus arbeidsgeschiktheidsclassificatie met $186 \%$.

Bij een unit-stiljing van één standarddeviatie op somatiseren en psychopathologie stijgt de desbetreffende kanswerhouding met respectievelijk $51 \%$ en $41 \%$.

Bij cen unit-stijging van één standaarddeviatie op de performale intelligentie blijkt de kans op een $A G+-c l a s s i f i c a t i e$ darentegen met $(1 / .59 \Rightarrow$ $.69 \%$ te diden .

Met becrekking tot de voorspellende warde van de psychometrische onderzoeksgegevens in volgorde van de gewichtstoekenning blijkt dat een hogere emotionele labiliteits-, somatiserings- en psychopathologiescore en een lagere performale intelligentiescore bepalend zijn voor de psychologische arbeids(on)geschiktheidsclassificatie.

De psychologische dimensies psycho-enotionele labiliteit, somatiseren, psychopathologie en performale intelligentie vertonen ten anzien van de psychologische arbeids(on)geschiktheidsclassificatie voldoende predictief vermogen .

De werbale intelligentie, het geslacht, de leeftijd en het opleidingsniveau hebben darentegen in deze studie geen of althans onvoldoende voorspellende warde met betrekking tot de psychologische arbeidstonjgeschiktheidsbeoordeling.

\section{9 .1 Discussie}

In het algemeen leidt het resultat van de statistische bewerkingen op het onderzoeksmateriaal tot de conclusie, dat er vier relevante psychologische dimensies zijn die de basis vormen voor de psychologische arbeids(on)geschiktheidsclassificatie. Deze bevinding vormt een bevestiging van de veronderstelling dat de gehanteerde psychometrische instrumenten voor de 
praktijk doeltreffend zijn en een objectiverende gebrukswarde kunnen hebben.

De statistische analyses geven een inzicht hoe aan de psychometrische kwancitacieve gegevens een relevante mate wan gewicht wordt toegekend in het beoordelings- en adviesbeleid wan de psycholoog-adviseur. op grond darvan kan worden gesteld dat her gebruik van de desbetreffende psychometrische onderzoekstinstrumenten een belangrijke ondersteuming kan zijn bij de psychollogische arbeids(on)geschiktheidsdiagnostiek.

Meer detail-gericht geeft een analyse van de onderzoeksresultaten aan dat de variabele 'schizofrenie' zowel een positieve lading blijkt te hebben op de component psycho-emotionele labiliteit als op de component psychopathologie. Dit heert naar alle warschijnlijkheid te maken net de heterogene itemsamenstelling van deze MPI-schaal (Harris en Lingoes, 1955).

Een inhoudsanalyse van de irems van de schizofrenieschaal heef a dat ex sprake is van een aantal homogene inhoudsdimensies, c.q. subschalen, welke betrekking hebben op respectievelijk ongewone lichamelijke sensaties, emotioneel-maffectieve, cognitieve en psychopathologische stoornissen (Greene e.a., 1980).

Derhalve is het op grond van deze onderzoeksresultaten mogelijk dat respondenten met in feite verschillende stoornissen allen hoog op de schizofrenieschaal kunnen scoren ( $\mathrm{T}$-score $>70)$, mat in feite tot diverse diagnosegroepen behoren.

Binnen de onderzoekspopulatie betreft dit respectievelijk de categorieën psycho-emotionele stoornissen en psychopathologische stoornissen.

De bevindingen van Moore e.a. (1988) dat de schizofrenie-itens van de MMI ook hoog kunnen laden op de factor somatiseren, en met name bij chronische pijnpatiënten, zonder dat er overigens sprake is wan ernatige psychopathologie, wordt door deze onderzoeksbewindingen niet bevestigd.

Tenslotte bevestigen deze onderzoksbevindingen, dat de samenstelling van het psychometrisch instrumentarium een aantal invariante psychologische hoofdimensies meet, wardoor het risico van een inadequate interprecatie van de psychologische bevindingen kan worden gereduceerd.

In deze context dient overigens nogmals te worden geconstateerd, dat in het kader van de psychologische arbeids(on)geschiktheidsdiagnostiek geen 
'objectief' crteriun aamezig is wartegen de psychologische onderzoeksbevindingen en de darop gebaseerde interpretaties en verstrekte adviezen kunnen worden afgezet dan alleen het oordeel van derden. Derhalve berust de 'objectiviteit' van de criterium variabele op consensus binner het zogenaamde "expert-systeem".

Het feit echter dat de psychologigche arbeids(on)geschiktheidschassificaties voorspelbat zijn uit de psychometrische onderzoeksgegevens, zoals deze worden gemeten door de hier toegepaste en geëvalueerde onderzoeksinstrumenten, betekent dat de oordelen niet subjectief en persoonsgebonden zijn. Door middel van het hanteren van psychometrische onderzoeksinstrumenten blijkt een individuele beoordelaar 'objectiveerbare' resultaten te kunnen behalen.

De warde van deze onder zoeksbevindingen is dan ook vooral bierin gelegen dat op grond van het gevonden statistische model, bestande uit de vier componenten psycho-emotionele labiliteit, somatiseren, psychopachologie en performale intelligentie, onderscheid kan worden gemakt tussen arbeidsgeschikten en arbeidsongeschikten.

Tevens kan dit model worden gebruikt om het "semi-klinisch oordeel" over een individuelle persoon te vergelijken met het 'statistisch oordeel'. Als het eigen semi-klinisch oordeel aiet overeenstemt met het oordeel volgens het statistisch model, kan de psycholoog-adviseur zich afvragen warom er sprake is van een discrepantie. Op grond van afwegen en beargumenteren kan dan het uiteindelijke oordeel tot stand komen en worden geëxpliciteerd.

In het algemeen kan worden gesteld dat dit statistische model niet is bedoeld om het semi-klinisch oordeel van de psycholoog-adviseur te vervangen, noch om diagnoses te stellen. Wel kan het een meer efficiente en consiscente verwerking van kwantitatieve informatie bewerkstelligen bij de psychologische arbeids(on)geschiktheidsdiagnostiek.

Wanneer derden bij de beoordeling van arbeids(on)geschiktheid zijn betrokken, verdient het a anbeveling dat dezelfde psychometrische onderzoeksinstrumenten worden gebruikt, opdat niet alleen bekend is welke variabelen bij de beoordeling zijn gebruikt, mar ook kan worden nagegaan welke 
gewichten aan elk van de gebruikte variabelen worden gegeven. Dit kan de "inter-beoordelaars betrouwaarheid" ten goede komen.

Bij gemeenschappelijke toepassing van de desbetreffende onderzoeksin strumenten kan bijeen afwijkend oordeel op grond van de desbetreffende psychometrische gegevens verificatie platsvinden, hetgeen verwolgens tot reflectie en discussie kan leiden, alvorens een definitief oordeel wondt gegeven.

6.10 PREDICTIENE NAARDE VAN DE COMBINATIE VAN PSYCHOLOGISCHE PERSOONSKENMERKEN MET BETREKKING TOT DE BESLISSTNGEN VAN DE OPDRACHTGEVERS

In dit onderzoeksgedeelte is nagegaan in hoeverre het beslissingsbeleid van de opdrachtgevers, gegeven de psychologische adviezen, kan worden verklaard c.q. voorspeld vanut bepalde psychologische persoonskenmerken.

Ter bepaling wan het voorspellend vermogen van de desber refende psychologische persoonskenmerken met betrekking tot de witeindelijke besluitvorming van de opdrachtgevers, is het verband tussen de variabelen geanalyseerd op univariat niveau door middel van de t-toets.

De vraag die daarbij centraal stat is: Wat is de predictieve waarde van psychologische persoonskenmerken, gegeven de psychologísche adviezen, afzonderlijk en in combinatie ten aanzien van de beoordeling door de opdrachtgevers?

Uit tabel 25 blijkt dat, gegeven het verstrekte psychologische advies, nast leeftijd en een traag tempo van functioneren, de volgende 16 van de 21 psychologische persoonskenmerken $(=76 \%$ een signjeficant voorspellende warde $(p<0.01)$ hebben ten aanzien van de witeindelijke arbeids(on)geschiktheidsbeoordeling var de opdrachtgevers: K-schal, hypochondrie, psychopathologische depressie, nysterie, psychopathische deviatie, paranồa, psychasthenie, schizofrenie, sociale introversie, psychoneurotische klachten, functionele lichamelijke klachten, sociale extraversie, toestandsangst, dispositie-angst, depressieve gevoelens en evaren gezondheidstoestand. 
Tabel 25: Geniddelden en t-toegtevinangen betreffende psychologiseme per

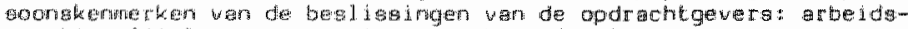

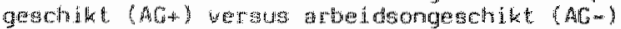

\begin{tabular}{|c|c|c|c|c|}
\hline \multirow{2}{*}{ 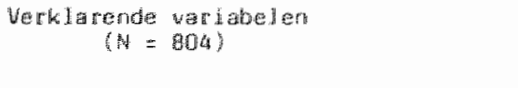 } & \multicolumn{2}{|c|}{ gem i didel de } & \multirow[t]{2}{*}{ I-xalate } & \multirow[t]{2}{*}{$p$-warde } \\
\hline & $A \mathrm{Al}+$ & $A G-$ & & \\
\hline bu iogear ische gegenenta & & & & \\
\hline 1. geadact & - & - & - & 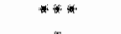 \\
\hline 2. leeftijo & 32.2 & 35.1 & -4.09 & F \\
\hline 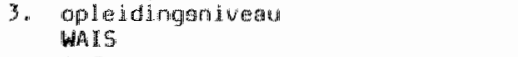 & 2.7 & 2.5 & 1.20 & 0.23 \\
\hline 4. inforthatie & 12.1 & 11.5 & 0.8 .1 & 0.41 \\
\hline 5. begr ijpen & 15.2 & 15.1 & 0.21 & 0.83 \\
\hline 6. rekengen & 9.0 & 9.3 & -0.80 & 0.42 \\
\hline 7. averemikomsten & 16.1 & 15.4 & 1.62 & 0.10 \\
\hline 8. ciffurreksen & 11.8 & 11.4 & 1.46 & 0.14 \\
\hline 9. woordenectut & 30.5 & 30.2 & 0.23 & 0.81 \\
\hline H0. gutstilutie & 52.0 & 4.7 .5 & 3.92 & in \\
\hline 11. onwoll ledige Hekieningery & 12.1 & 11.2 & 1.51 & 0.13 \\
\hline 12. bilokpitconen & 17.2 & 1.6 .7 & 0.91 & 0.36 \\
\hline 13. platijes rangechikken & 14.4 & 13.6 & 2.00 & $0.04 \%$ \\
\hline $\begin{array}{l}\text { 14. figuir leggen } \\
\text { DAT }\end{array}$ & 45.2 & 44.8 & 0.28 & 0.77 \\
\hline 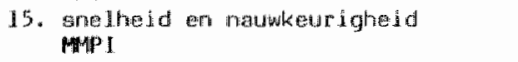 & 57.6 & 54.4 & 2.40 & * \\
\hline 16. L-schea.l & 13.8 & 14.2 & -0.21 & 0.83 \\
\hline 17. F-seheal & 9.4 & 10.6 & $-2.2 B$ & $0.02 *$ \\
\hline 10. K- Kucha & 14.6 & $13: 1$ & 3.73 & $*$ \\
\hline 19. Mypocthondrie & 12.6 & 15.2 & -4.46 & $*$ \\
\hline 20. pathollogische depressie & 25.3 & 28.2 & -4.72 & * \\
\hline 21. hyoterie & 29.4 & $\$ 1.9$ & -4.30 & * \\
\hline 22. psychopathische dewiatie & 20.3 & 21.8 & -2.80 & $*$ \\
\hline 23. anciwiteit/passiviteit & 31.0 & 30.0 & 1.69 & 0.09 \\
\hline 24. peranoüa & 11.9 & 13.2 & -3.37 & $*$ \\
\hline 25. pgyehasthenie & 17.7 & 21.7 & -4.58 & $*$ \\
\hline 26. schizofrenie & 19.6 & 23.9 & -4.20 & * \\
\hline 27. Mypronanie & 19.1 & 19.6 & -1.26 & 0.20 \\
\hline $\begin{array}{l}\text { 26. Sociale introwersie } \\
\text { ABS }\end{array}$ & 31.0 & 34.3 & -3.68 & $*$ \\
\hline 29. psychoneurotigche klachten & 67.0 & 76.5 & -4.08 & * \\
\hline 30. functionele lichamelijke klachten & 23.5 & 26.5 & -4.04 & * \\
\hline 31. sociale extrawersie & 51.5 & 46.6 & 3.38 & $*$ \\
\hline $\begin{array}{l}\text { 32. zelfuferensieve instedling } \\
\text { zBu }\end{array}$ & 37.9 & 39.0 & -1.42 & 0.15 \\
\hline 33. toe tandaranget & 44.5 & 49.0 & -5.07 & * \\
\hline $\begin{array}{l}\text { 34. dispositio-anget } \\
\text { ZUNG }\end{array}$ & 45.4 & 49.9 & -4.90 & $*$ \\
\hline $\begin{array}{l}\text { 35. Jepregereve geuber lang } \\
\text { votc }\end{array}$ & 40.1 & 44.7 & -5.15 & * \\
\hline $\begin{array}{l}\text { 36. ervaren gozondhe d dotoestand } \\
\text { p5 }\end{array}$ & 18.0 & 22.5 & -4.96 & $*$ \\
\hline 37. pi jubel aving & 2.7 & 3.1 & -1.58 & 0.11 \\
\hline
\end{tabular}

$*: p<0.01$

* : $: 0.05$

** : * *annen-vrowwen chi2 $=10.40, p=0.00$

Een analyse met behulp van cweezijdige t-toetsing op basis van de gemiddelden van de variabelen van de verklarende componentem, zoals beschreven in subparagraf 6.9 , met betrekking tot de $A G+-v e r s u s$ AG-beslissing van de 
opdrachtgever geeft een significant verschil op de componemen psychom emotionele labiliteit en somatiseren. Als zodanig hebben deze twee compow nemten, gegeven de psychologische adviezen, een vootspellende warde met betrekking tot de uiteindelijke beslissing van de opdrachtover dit in regenstelling tot de componenten verbale intelligentie, performale intelligentie en psychopathologie. Deze gegevens stán weergegeven in tabel 26.

Tabel 26: Cemiddelden van de variabelen van de componenten en t-totsbewiminm gen, verdeell nat de beslissingen van de opdrachtgevers: arbeldisgoschikt ( $A C_{*}$ ) wersus arbeidsongeschikt (AG-)

\begin{tabular}{|c|c|c|c|c|}
\hline \multirow[t]{2}{*}{ Componenten } & \multicolumn{2}{|c|}{ gemidde l de } & \multirow[t]{2}{*}{ T-wararde } & \multirow[t]{2}{*}{$p-$ waa $r e$} \\
\hline & $A G+$ & $A G-$ & & \\
\hline psycho-emotionele labiliteit & -0.27 & 0.10 & -4.27 & $*$ \\
\hline verbale intelligentie & -0.03 & 0.10 & $-0,48$ & 0.62 \\
\hline somat iseren & -0.20 & 0.00 & -3.20 & H: \\
\hline psychopathologie & -0.01 & 0.00 & -0.20 & 0.84 \\
\hline performale intelligentig & 0.08 & 0.03 & 1.22 & 0.22 \\
\hline
\end{tabular}

* p< 6.01 bi j tweezijolige toetsing

\section{10.1 Discussie}

Het blijkt dat door middel van statistische analyses van psychometrische gegevens psychologisch relevante aspecten van de klinische beoordeling door verzekeringsgeneeskundigen kunen worden geëxpliciteerd.

Dit is een vorm van 'policy-capturing', waardoor inziche kan worden verkregen hoe, onder meer op basis van psychologische persoonskenmerken, de verzekeringsgeneeskundige oordeelsworming tot stand kont.

Marom de componenten psycho-emotionele labiliteit en somatiseren well den woorspellende warde hebben met betrekking cot het beslissingsbeleid wan de opdrachtgevers, terwijl dit niet het geval is wat betreft de performale intelligentie, de verbale intelligentie en de psychopathologie, is op grond van de beschikbare onderzoeksgegevens niet zonder meer te verklaren. Een scatistische amalyse van het beslissingsproces wan werzekeringsgenes- 
kundiger zou meer inzicht kunnen geven hoe hut oordeelsworming tot wand lomt, welke criteria door hen dadwerkelijk worden gehanteerd en welk gewicht daarbijwordt toegekend aan de psychonetrische onderzoeksgegevens en de mede daarop gebaseerde psychologische arbeids(on)geschiktheidsadvitenten. 


\section{CONCLUSIES EN AANBEVELINGEN}

Dit onderzoek heeft zich gericht op de bepaling van de "objectiverende" warde van een aantal psychometrische onderzoeksinstrumenten in het kader wan de psychologische arbeids(on)geschiktheidsdiagnostiek. De resultaten van dit onderzoek, welke vooralsnog alleen gelden voor de desbetreffende onderzoekspopulatie binnen de grenzen van de plats warop eth het tijdsbestek waarbinnen de gegevens zijn verzameld, kumen worden gerangshik onder de noemer van de "descriptieve beslissingstheorie' (slovic e.a., 1977). Zij hebben betrekking op een statistische analyse van de wijze warop de psycholoogmadviseur hem bekende psychonetrische onderzoeksbevindingen heeft verwerkt bij het nemen van beslissingen in het kader van de psychologische arbeids (on) geschiktheidsbeoordeling.

Samenvatcend leiden de bevindingen van het onderhavige onderzoek tor de hiervolgende conclusies en aanbevelingen met betrekking cot:

- (voorlopige) beslissingsregels voor de psychologische arbeids(on)geschiktheidsdiagnostiek (7.1);

- de samenstelling van een psychometrisch onderzoksinstrumentarium voor de psychologische arbeids(on)geschiktheidsdiagnostiek (7, 2);

- het verrichten van vervolgonderzoek (7.3);

- de opleiding en bijscholing voor diegenen die werkzam (zullen) zijn in het werkveld van de sociale verzekeringspsychologie en verzekeringsgeneeskunde $(7.4)$.

Tot slot (7.5) wordt arbeidsongeschiktheid ten gevolge van psychische stoornissen niet alleen als individueel probleem, mar ook als matschappelijk, bedrijfstructureel en sociaal-economisch probleem geformuleerd, warmee in het kader van de psychologische arbeids(on)geschiktheidsdiagnostiek actief rekening dient te worden gehouden.

7. 1 VOORLOPIGE BESLISSINGSREGELS VOOR DE PSYCHOLOGTSCHE ARBETDS(ON) GE SCHTKSHE IDSD LAGNOST IEK

De gehanteerde en geëvalueerde psychometrische onderzoeksinstrumenten meten 34 variabelen (indicatoren), welke betrekking hebben op de psychische belastbatheid en beroepsvaardigheden. Het is mogelijk om op basis 
van deze psychologische onderzoeksgegevens, gegeven het besilissingsmodel, een adequate beoordeling inzake de arbeids(on)geschiktheid te geven.

Van de 34 variabelen blijken er $30(=85 \%)$ wan inwloed te 2 iju ap de psychologische arbeids(on) geschiktheidsclassificatie.

Op grond van deze onderzoeksesuitaten kan worden gesteld dat het gehanteerde psychologische onderzoksprotocol, inclusief het darbij gebrukte psychometrische instrumentarium, goed bruikbat is, doch overigens niet als volledig kan worden betiteld.

Gerelateerd an het verzekeringsgeneeskundig oordeel blijkt bijna $75 \%$ van het total antal verstrekte psychologische arbeids(on)geschiktheidsadviezen te zijn overgenomen en dus correct te zijn geclassificeerd.

Gerelateerd aan het verzekeringsgeneeskundig oordeel blijken alle psychologische arbeidsongeschiktheidsclassificaties in dezen correct te zijn voorspeld (100\%), cerwijl dit voor de psychologische arbeidsgeschiktheidsclassificaties in bijna $65 \%$ het geval blijkt te zijn.

Hoewel er geen eenduidige verklaring is te geven voor de geringere mate van sensitiviteit en specificiteit wan het psychologisch onderzoeksprotocol met betrekking tot de categorie arbeidsgeschikten, kan worden verondersteld dat dit o, a. een gevolg is van het feit dat de uiteindelijke arbeids(on)geschikcheidsbeoordeling door de opdrachtgevers mede berust op andere dan somatische en psychologische factoren.

Met betrekking tot het voorspellend vermogen van de psychometrische onderzoeksbevindingen ten aanzien van de categorie mensen die wel en niet in beroep gaan, kan worden geconcludeerd dat mensen die in beroep gaan psychisch "gezonder" zijn dan zij die dat niet doen.

Met betrekking tot de kans op he winnen of verliezen van een beroepszak geldt landelijk, dat er in geval van psychische scoornissen eer kans wan meer dan $50 \%$ is dat betrokkene een dergelijk beroep wint.

De resultaten van deze studie wijzen in de richting dat, wanneer een psychologisch onderzoek plaatsvindt door middel van psychometrische instrumenten, de onderzoeksbevindingen met betrokkene besproken worden en het advies beargumenteerd wordt, de kans bestaat dat er niet alleen sprake is van een aanzienlijk minder arot al mensen dat, vergeleken met landelijke cijfers, in beroep gat ( $5 \%$ versus $14 \%$ ), mar dat dit tevens de kans op 
een gegrondverklaring van een voor beroep vatbare beslissing reduceert $67 \%$ in het onderzoek versus $60 \%$ landelijk).

Dit geldt echter niet ingeval er sprake is van retrospectief onderzoek met vaagstellingen of bepalde uitsluitingsartikelen van de $2 W$, AAW, WAO of ABP-wet aan de orde zijn. Dit leidt in de meeste gevallen warin door meerdere deskundigen een beoordeling wordr gegeven tot tegenstrijdige uitspraken.

Een verklaring daarvoor kan niet aan de ondertoeksbevindingen van deze studie worden ontleend, al mag wel worden verondersteld dat gezien de aard wan de psychische problematiek en de beschikbare onderzoeksmethoden retrograde uitspraken altijd wel een zekere onbetrouwbatheid blijuen houden en daamee de kans op variabiliteit in de uiteindelijke beoordelingen mogelijk maken.

De in deze studie onderzochte meetbare psychologische persoonskenmerken betreffende de psychische belastbarheid en beroepsuardigheden zijn geoperationaliseerd in vijf samengestelde componenten: verbale intelligentie, performale intelligentie, psycho-emotionele labiliteit, psychopathologie en somatiseren. Vier van de vijfi componenter hebben een predictieve warde ten anzien var de arbejds(on)geschiktheidsclassificatie van de psycholoog-adviseur. Met name de verbale incelligentie blijkt gean voorspellend vermogen te hebben met betrekking tot de classificatie van arbeidsgeschikten versus arbeidsongeschikten.

De psychologische classificatie is derhalve in wolgorde wan gewicht, gebaseerd op de samengestelde psychologische componenter:

- psycho-emotionele iabiliteit;

- somatiseren;

- psychopathologie;

- performale intelligentie.

Deze componenter hebben een voorspellende en darmee "objectiverende' warde met betrekking tot de psychologische arbeidsongeschiktheidsbeoorde ling.

Gegeven het gehanteerde onderzoeksprotocol en de vier voornoende voorspellende samengestelde psychologische componenten kunnen ter verhoging van de objectiviteit en effectiviteit van de psychologische arbeidsconge- 
schiktheidsdiagnostiek de volgendz (woorlopige) beslissingsregels worden geformulerd:

1e. De classificatie "arbeidsongeschikt" is aan de orde wanneer de psychometrische gegevens, refererend aan de geniddelde normscore, eert afwijkende score te zien geven op de schalen betreffende de componenten:

- psychomemationele labiliteit;

- somatiseren;

- psychopathologie;

- performele intelligentie.

De geconstateerde componentenladingen van de desbetreffende psychometrische schalen (zie tabel 2 la, $c, d$ en $e$ ) kunnen in dit verband Fungeren als beoordelingscriteria. Een positieve componentenlading impliceert een positieve correlatie; een negatieve componentenlading betekent een negatieve correlatie.

Bij een pasitieve correlatie behoort een verhoogde score en bij een negatieve correlatie een verlaggde score, vergeleken met de gemiddelde normscore. In geval van een individuele casus kunnen deze scores worden vergeleken met de correlaties (criteria), zoals deze staan weergegeven in tabel 27.

Er is sprake van een verhoogde kans op een adequate arbeids(on)geschiktheidsclassificatie, wanneer bij de oordeelsvorming wordt uitgegaan van de mate van overeensteming tussen de individuele psychometrische onderzoeksgegevens en deze beoordelingscriteria.

2e. Alvorens tot een definitieve oordeelsvorming inzake de arbeids(on)geschiktheid te komen, dienen twee onafhankelijke voorspellingen te worden gedan op basis van respectievelijk de kwalitarieve (anamestische) en kwnt it at ieve (psychometrische) gegevens.

De psychologische arbeids(on)geschiktheidsclassificatie is wat dat betreft een semi-klinische beoordeling, gebaseerd op klinische en stat istische data.

Het in dat kader eerst opstellen van twee onafhankelijke voorspellingen, alvorens tot een definitieve oordeelsworming (beslissing) wordt overgegan, vermindert de kans dat een inadequate beslissing 
Tabe 1 27: Ouerzicht van de relewante samengestelde componenten en afzorderlijke predictorer als criteria voor de psychologische arbeids (on) geschilithe idsclassificatie

\begin{tabular}{|c|c|c|c|}
\hline \multirow[t]{2}{*}{ Componenten } & \multirow{2}{*}{$\begin{array}{l}\text { Psychol og ische } \\
\text { persoonskenterken }\end{array}$} & \multicolumn{2}{|c|}{$\begin{array}{l}\text { Couteria psychologische arbedels- } \\
\text { hongeschiktheidsel assificat id }\end{array}$} \\
\hline & & $\begin{array}{c}\text { arbedidsgeschikt } \\
(\mathrm{AC+})\end{array}$ & $\begin{array}{l}\text { abeidsongeschikt } \\
(\mathrm{AG})\end{array}$ \\
\hline $\begin{array}{l}\text { 1. psycho-renotione le } \\
\text { labilitteit }\end{array}$ & $\begin{array}{l}\text { socialle introversie } \\
\text { psychesthenie } \\
\text { sociale extraversie } \\
\text { disposite-angst } \\
\text { toestandsangst } \\
\text { pathollogische depressie } \\
\text { psychoneurotische klachten } \\
\text { depressiewe gevolens } \\
\text { schizaf renie } \\
\text { correctieschal }\end{array}$ & $\begin{array}{l}- \\
- \\
+ \\
- \\
- \\
- \\
- \\
- \\
+\end{array}$ & $\begin{array}{l}+ \\
+ \\
- \\
+ \\
+ \\
+ \\
+ \\
+ \\
+ \\
+\end{array}$ \\
\hline 2. somatiseren & $\begin{array}{l}\text { nypochondrie } \\
\text { hysterie } \\
\text { functionele lichamelijke klachten } \\
\text { ervaren gezondhe udstoestand } \\
\text { pijnbelewing }\end{array}$ & $\begin{array}{l}- \\
- \\
- \\
-\end{array}$ & $\begin{array}{l}+ \\
+ \\
+ \\
+ \\
+\end{array}$ \\
\hline 3. psychopatholagie & $\begin{array}{l}\text { manje } \\
\text { F-schaal } \\
\text { schizofrenie } \\
\text { psychopathische deviatie } \\
\text { paranoina }\end{array}$ & $\begin{array}{l}- \\
- \\
-\end{array}$ & $\begin{array}{l}+ \\
+ \\
+ \\
+ \\
+\end{array}$ \\
\hline $\begin{array}{l}\text { 4. per formale } \\
\text { intelligentie }\end{array}$ & $\begin{array}{l}\text { substitutie } \\
\text { figutrileggen } \\
\text { blakpatronen } \\
\text { sneaheid en nauweurighe id } \\
\text { plaatjes rangschikken }\end{array}$ & $\begin{array}{l}+ \\
+ \\
+ \\
+\end{array}$ & $\begin{array}{l}- \\
- \\
-\end{array}$ \\
\hline
\end{tabular}

* = vertwoogde score vergeleken mat de gemiddelide normisore

- = ver laagde score vergeleken met de gemiddeldie nomscore

wordt genomen. Daamee kan met name zoveel als mogelijk worden voorkomen dat aan niet-relevante gegevens onevenredig veel gewicht wordt toegekend in de oordeelsvorming. Het scheiden wan enerijds de twee vormer van respectievelijk kwatiteits ${ }^{-}$en kwalteitsvoorspellingen en anderzijds de ute indelijke beslissing biedt de mogelijklneid on de verschillende relevante argumenten te inventariseren en te vergelijken. Daarbij kan een eventuele discongruentie tussen de twee worspellingen expliciet worden gemakt. Op grond vankennis, inzicht en ervaring kunnen dan de argumenten nader worden gewogen in relatie tot de criteria wan de referentieberoepen en kan de uiteindelijke oordeelsvorming platsvinden. Openlad omtrent de argumenten en gewichtsverlening daaraan bij de oordeelsvorming makt verificatie en discussie mogelijk. Een dergelijke openheid vorm tegelijkertijd de 
voorwarde voor de verantwoording van de witeindelijke beslissing. Statistische analyses van beslissingen kunen leiden tot thet ontwkelen van prescriptieve modelien en diagnostische beslissingssystemen. Deze modellen en beslissingssystemen kumen op zich de basis vormen voor de beoordeling van de instrumentele utiliteit van bepalde onderzoeksinstrumenten in het kader van de psychologische arbeids (on)geschiktheidsdiagnostiek.

\subsection{EEN PSYCHOMETRISCH ONDERZOEKSINSTRLMENTARTUM VOOR DE PSYCHOLOGISCHE ARBETDS(ON)GESCHIKTHETDSDTAGNOSTIEK}

De instrumentele utiliteit van een toegepast psychometrisch onderzoeksinstrumentarium en de relevantie van de variabelen die daarmee worden gemeten, heeft betrekking op de mate warin ze voldoen an de doelstelling wan de toepassing en de doeltreffendheid ervan (De Groot, 1972).

Binnen de context en de opzet van deze studie gat het om het vaststellen of de desbetreffende psychologische variabelen een zinvolle bijdrage leveren aan de 'voorspelling' van de arbeids(on)geschikthed van mensen thet vermeende psychische stoornissen. De samenstelling van het psychomerrisch onderzoeksinstrumentariun, zoals in dere studie is geêvalueetd, bestat wit gestandardiseerde psychologische tests, inclusief vragen1ijsten, warvan de validiteit en betrouwbarheid in het algemeen bekend zijn (Visser e.a., 1982).

Het feit dat $85 \%$ van de gehanteerde variabelen een zinvolle bijdrage lewert aan de psychologische beoordeling arbeidsgeschikt/arbeidsongeschikt en deze beourdeling in $75 \%$ van het total antal gevallen goed is geclassificeard, impliceert dat de samenstelling van het onderzoek voldoet aan de eisen van nawkeurigheid en elfectiviteit.

Hicruit mag worden geconcludeerd dat de samengestelde "onderzaeksbatcerij" en daarmee de kwantificeerbare componenten een belangrijke basis vormen voor het nemen wan praktische beslissingen in het kader van de psycholoische arbeids (on)geschiktheidsdiagnost iek.

Mer betrekking tot de "instrumentele utiliteit" van de geêvalueerde onder- 
zoeks instrumenten $h_{2}$ an worden gesteld dat de samenstelling adequat is voor de psychologische arbeidston)geschitheidsclassificatie wat betreft:

- de Wechsler Adult Inteligence Scale: performale gedeelte (J. Stinissen e.a., 1970);

- de Differentiële Aanleg Test: snelheid en nauwkeurigheid (S.D. Fokkema, A. Dirkzwager, 1968 );

- de Nederlandstalige Minnesota Multiphasic Personality Inventory (MMP, C-vorm), (J. Nuttin en J.B. Beuten, 1969);

- de Amsterdamse Biograrische Vragenlijst (G.J.S. Wilde, 1970);

- de Zelf-Beoordellings Vragenlijst (H.M. van der Ploeg, P.B. Defares, C.D. Spielberger, 1980);

- de depressieschal van Zung (1973);

- de Vragenlijst voor Onderzoek van de Ervaren Gezondheidstoestrand (J.M. Dirken, 1974);

- de pijnschad (Fordyce, 1976).

Behalve dat dit samengestelde psychometrische instrumentarium aen adeguat hulpmiddel blijkt te zijn bij de psychologische classificatie van arbeidsa geschiktheid versus arbeidsongeschiktheid, draggt de toepassing ervan bij tot inzicht in:

- de kans dat een psychologisch arbeids(on)geschiktheidsadvies daadwerkelijk door de opdrachtgever zal worden overgenomen;

- de kans dat betrokkene tegen een op het psychologisch advies gebaseerde 'voor beroep vatbare beslissing" in beroep zal gaan.

Bovendien wijzen de onderzoeksbevindingen in de richting dat hantering van dit instrumentarium, gegeven het beschreven psychologische onderzoeksprotocol, de kans op beroepszaken en het gegrond verklaren ervan kan reduceren.

Met betrekking tot de arbeids(on)geschiktheidsclassificaties mag gexien de onderzoeksresultaten van deze studie verder worden geconcludeerd, dat het gebruik taken van voornoemde psychometrische onderzoeksinstrumenten een belangrijke bijdrage kan leveren an de verhoging van onderlinge vergelijkbaatheid en verifieerbaarheid wan onderzoeksgegevens en adviezen inzake arbeidscon lgeschik theid.

Het is a an te bevelen om in ansluiting op de bevindingen van deze studie 
door middel van voortgezt onderzek de sensitiviteit, specificiteit en efficiency yan het gehanteerde psychologische onderzoeksinstrumentarium verder de verbeteren.

\section{3 VERVOLGONDERZOEK}

Op grond wan de bevindingen dat vier relevante psychologische kwantificeerbare dimensies een rol spelen in de psychologische arbeidscongeschiktheidsbeoordeling en, met uitzondering van de performale intelligentie, arie ervan vergelijkbar lijken te zijn met de schalen negativisme, soma tiseren en psychopathologie van de Nederlandse Verkorte MMPI (NVM) van Luteijn (1980), is nader onderzoek naar deze vergelijkbaarheid en mogel ijk wervangaarheid vanuit rendementsgezichtspunt zinvol.

Het verdient vervolgens anbeveling on daarbij op grond wan de onderzoeksgegevens van Koele (1987) ook de subschalen van de Nederlandse Persoonlijkheids Vragenlijst (MPV) van Luteijn, (1985) in het onderzoeksdesign op te nemen.

Uit het onderzoek van koele (1987) is door middel van discriminant-analyse gebleken dat en antal subschalen van de NPV, met name de inadequatie- en de sociale inadequatieschaal, een discriminerende warde hebben bij de classificatie van arbeidsongeschikten en arbeidsgeschikten in geval van psychische problematiek.

Het heeft vooralsnog de voorkeur on bij vervolgonderzok alle subschalen Wan de NPV te ber rekken, omdat met behulp van de combinatie van de NPV en NWM een antal onathankelijke psychische dimensies worden gemeten, die volgens Luteijn (1985) in ieder geval voor de klinische context voldoende dekkend zijn.

Door alle subschalen van deze twee persoonlijkheidswragenlijsten in de onderzoeksopzer. te betrekken kan per dimensie de voorspellende warde met betrekking rot de psychologische arbeids(on)geschiktheidsclassificatie worden beparad.

Mogelijk kan het voorspellend vermogen van het samengestelde psychometrische onderzoeksinstrumentarium nog worden vergroot door tevens de 
subschalen van de Prestatie Motivatie Test (PMT) wan Hermans (1975) daar aan toe te voegen.

Uit het onderzoek van Broekhuis (1985) is namelijk gebleken dar de 'prestatie-motivatie" van betrokkene in ieder geval van invloed is op de oordeelsworming van de medewerkers van de Gemenschappelijke Medische Dienst (GM), terwijl falangststoornissen dikwijls dadwerkelijke cerugkeer in het arbeidsproces belemine cen (Hoencamp en Reinhart. 1988).

In hoeverce de dimensies 'prestatie-motivatie' en "faalangststoornissen' als aparte dimensies een rol spelen in de oordeelsvorming van de externe deskundige adviseurs is tot nu, woor zover bekend, nooit nader onderzocht, mar verdient op grond van voornoemde bevindingen wel nadere analyse.

Afgezien van de objectiverende warde die het performale deel van de WAIS in de psychologische arbeids(on)geschiktheidsbeoordeling blijkt te hebben, is het zeker zinvol om na te gaan of dit veel tijd vergende gedeelte kan worden vervangen door een korter durende test. Daarbij kan worden gedacht aan de schriftelijke verkorte vorm van de Groninger Intelligentie Test (GIT: Snijders en Verhage, 1983).

De voorkeur voor deze schriftelijke verkorte GIT is verder gebaseerd op grond van de begripsvaliditeit, betrouwbarheid en geschiktheid woor lager geschoolden, en is bovendien genormeerd voor AAw/WAO-uitkeringsgerechtigder (Kooreman en Luteijn, 1987).

Bij vervolgonderzoek kan worden overwogen ook meer specifiek taakgerichte gestandardiseerde onderzoeksinstrumenten te banteren en hun warde voor de psychologische arbeids(on)geschiktheidsclassificatie te bepalen. Dar-bij kan worden gedacht an specifieke taak-en functiegerichte psychometrische onderzoeksmethoden (Visser e.a., 1982).

Door specifieke taak- en functiegerichte onderzoksmethoden in het onderzoeksdesign te betrekken, mag meer inzicht en darmee een meer reäle beoordeling van het (resterende) arbeidsvermogen worden verwacht.

Na een dergelijke (stapsgewijze) ontwikeling van een samengesteld psychometrisch onderzoeksinstrumentarium kan door middel van kruisvalidatie (Nunally, 1978) tenslotte worden nagegan in hoeverre de verkregen resultaten met succes gebruikt kunnen worden bij het voorspellen wan 
arbeidsgeschikten versus arbeidsongeschikten. Darme kan een indicatie van het algeneen voorspellend $c$. ab obectiverend vermogen van het samengestelde psychometrische instrumentarium voor de psychologische arbeids(on)geschiktheidsdiagnostiek worden verkregen.

Het is langzamerhand algemeen geaccepteerd, dat het hanteren van een standard onderzoksprotocol en het daatij gebruik maken van hetzelfde psychometrische onderzoksinstrumentarium een noodzakelijke voorwarde is orn meer consistentie en betrouwbarlieid in de oordeelsworming inzake arbeids (on)geschiktheid bij vermeende psychische stoornissen an te brengen.

Standaardisering van het onderzoeksprotocol, het moeten voldoen an minhmale eisen wat betreft het hanteren van een adequat en goed voorspellend psychodiagnostisch anderzoeksinstrumentarium en een gestructureerde verslaglegging vormen daarbij belangrijke voorwaarden, zonder dat dit ten koste hoeft te gaan van de inventiviteit en wetenschappelijke creativiteit van de onderzoeker-adviseur.

De verantwoordelijkheid van adviseurs inzake arbeids(on)geschiktheid verelst controleerbarheid en zonodig corrigeerbarheid van het functioneren van de onderzoeker-adviseur. Inzichtelijkheid in de onderzoeksgegevens en de criteria warop de beslutivorming platesvindt, kan feitelijke willekeur voarkomen.

Ondat de psychologische arbeids(an)geschiktheidsdiagnostiek, nast een kwantitatief aspect ook een kwalitatief aspect kent, is het censlotte aan te bevelen om bij vervolgonderzoek de kwaliteit van de subjectieve betekeniswerlening an het werk, de referentieberoepen en de werkuitvoerings eisen te betrekken. Hoe de kwaliceit van de subjectieve betekenisverlening in relatie tot de kwaliteit van het werk, de referentieberoepen en de werkwitwoetingseisen en arbeidsomstandigheden kan worden gemeten, wordt verwezen naar recente onderzoeksresultaten op dit gebied van Zanders (1975), Biderman en Drury (1976), Thierry e.a. (1977), De Sitter (1981), De Galan e. $(1983)$ en Grosfeld (1988). 


\subsection{OPLETDENG EN BUJSCHOLING}

Gezien het toenemend belang wan psychologisch onderzoek in het kader van de arbeids(on)geschiktheidsbeoordeling is het an te bevelen om scholingsmogelijkheden in deze zeer gespecialiseerde richting te creèren en verder wit te bouwen op universitait en postdoctoraal niveau. Recentelijk zijn wel universitaire opleidingen op dit specifieke gebied van de 'Psychologie van Arbeid en Gezondheid" gestart (Schabracq, 1988), maar op postacademisch niweau bestaat de deskundigheidsontwikeling tot nu toe uitsluitend uit autodidactie en praktijktraining in 'in-service' vorm.

Enige vorm van gestructureerde opleiding of bijscholing voor degenen die zich in de praktijk bezighouden met de psychologische oordeelsvorming inzake arbeids(on)geschiktheid ontbreekt nog steeds.

Nast universitaire opleidingen kumen intervisie-bijeenkomsten, seminars en postdoctorale cursussen in de behoefte aan opleiding en bijscholing voorzien, cerwijl, al of niet door middel van het instellen van een universitaire leerstoel, an een specifieke voortgezette beroepsopleiding 'socialle verzekeringspsychologie' kan worden gedacht.

Daarbinnen kan dan gericht aandacht worden besteed aan de wijze waarop de arbeidscon)geschiktheidsdiagnostiek in geval van psychische stoornssen zo adequat mogelijk kan plaatsvinden en tevens worden onderzocht hoe de arbeids(on)geschiktheidsdiagnostiek in het kader van de humanisering van de arbeid een bijdrage kan leveren aan de preventie van ongeschikte arbeid.

\subsection{SLOTBESCHOUWING}

Ter afsluiting van deze studie over psychologisch onderzoek inzake arbeids(on)geschiktheid is het niet alleen wenselijk, mar zelfs noodzakelijk erop te wijzen dat arbeidsongeschiktheid ntet alleen een individued. probleem, war ook een matschappelijk, bedrijfsstructureel en socialleconomisch probleem is.

Bij arbeidsongeschiktheid stat de verstoorde relatie tussen het individu en zijn of hat arbeid en arbeidsomstandigheden en in bredere zin her 'arbeidsbestel' (Kwant, 1964) central. 
Deze studie heef zich beperkt tot de individuele psychologische arbeids(on)geschiktheidsbeoordeling. Daarbij is in het bijzonder ingegaan op de psychometrische aspecten van de pisychologische arbeids(on)geschiktheidsdiagnostiek. De individuele kwalitatieve anamestische gegevens van de onderzoekspopulatie en de mogelijike oorzaken van arbeidsongeschiktheid op meso- en macroniveau zijn buiten de onderzoeksopzet gehouden.

Uit de literatuur, weergegeven in hoofdstuk 3, blijkt dat niet alleen individuele, persoonsgebonden factoren en omstandigheden, maar ook matschappelijke, bedrijfsstructurele en social-econonische veranderingen en ontwikkelingen kunnen leiden tot psychische en psychosomatische klachten en arbeidsongeschiktheid. Met name de wijze warop de arbeid tot nu toe is verdeeld en georganiseerd, de toenemend verslechterde kwaliteit van de arbeid met het structureel. tekort aan geschikte arbeidsplatsen en tegelijkertijd de feitelijke en ideologische betekenis en warde die nog steeds wordt gehecht aan het verrichten wan bet alde arbeid, verhogen het risico van psychische en psychosomatische klachten (Den Heeten e.a., 1988). Door individualisering en medicalisering van onze samenleving en verruiming van het ziektebegrip in psychische en psychosomatische richting bestaat de kans dat het etiket 'medisch arbeidsongeschikt' wordt gehanteerd, met verhulling van het ziekmakende effect van het hedendaagse arbeidsbestcel en de daarmee samenhangende matschappelijke problenatiek en cegenstellingen.

De reductie van maatschappelijke, bedrijesstructurele en sociaal-economische problemen tot een individueel probleem wordt versterk door de algenene individualiseringstendens, die inherent is aan de naoorlogse ontwikkeling wan onze samenleving, inclusief de actuele arbeidsongeschikthe idswet geving.

Individualisering is een maatschappelijk mechanisme dat onder meer de aandacht afleidt van de ongeschiktheid van arbeid en arbeidsomstandigheden en derhalve de structurele oorzaken van arbeidsongeschiktheid versluiert.

Tegen deze achtergrond kan de psychologische arbeids(on)geschiktheidsdiagnostiek zich dan ook niet alleen beperken tot de individuele beoordeling van de arbeids(on)geschiktheid, maar dient zij mede een signalerende bijdrage te leveren aan de preventie varn ongeschikte arbeid (Grosfeld, 1988). op het individuele beoordelingsniveau kan an de preventie van ongeschikte 
arbeid door psychologen worden meegewerkt door systamatisch to registreren er in de onderzoksrapportage expliciet a an te geven welke in de arbeidssicuaties gelegen factoren een rol spelen bij de ontwikkeling wan psychische en psychosomatische stoornissen. Dethalve hoort bij de beoordeling van arbeidsongeschiktheid op individueel niveau ook een kwaliteitsbeoordeling van de werkzamheden en onstandigheden waraan moet worden gerefereerd.

Ervan uitgande dat de psychologische arbeidscongeschiktheidsdiagnostiek per definitie een kwantitatieve en kwalitatieve evaluatie betretc van enerzijas de individuele psychische belastbarheid en beroepsvardigheden en anderzijds de werkzamheden en werkonstandigheden waraan moet worden gerefereerd, dient een psycholagische arbeidsongeschiktheidsbeoordeling de volgende aspecten te bevatten:

1e. de constatering dat er sprake is wan ziekte of gebrek in termen van stoornissen en daarmee samenhangende beperkingen in psychische belastbaarheid en beroepsvaardigheden.

2e. de beeldworming van de intrinsieke en extrinsieke kwalteiten van het werk en de werkomstandigheden van betrokkene, dan well van de werkzamheden en omstandigheden waraan vanuit de wet dient te worden gerefereerd.

3e. een beeldworming omtrent de relatie cussen de stoornissen (ziekte en gebreky enerzijds en de aard en de kwaliteit van de te verrichcen werkzaamheden en onstandigheden anderzijds.

4e. een beeldvorming van de psychische belastbaarheid, potentiële schom lings- en beroepsvaardigheden en affiniteiten, waardoor niet alleen een classificatie arbeidsgeschikt versus arbeidsongeschikt voor loonverdienend werk mogelijk is, maar ook de "andersgeschiktheid' ofwel de toegankelijkheid voor ander nutcig wel. of niet betaald werk naar voren koint .

5e. voor welke vormen van behandeling en/of begelleiding betroklkene in a anmerking komt.

6e. welke veranderingen wenselijk dan wel noodzakelijk zijn in de inhoud van de desbetreffende werkzamheden en omstandigheden, teneinde arbeidsongeschiktheid en ongeschikte arbeid te voorkomem. 
Het op voomoende wijze terugkoppelen naar de verzekerings- en bedrijesgeneesundige sector van de psychologische onderzoeksbevindingen en daaraan ontleende psycho-sociale implicaties met betrekking tot de kwallueit van de arbeid en de arbeidsomstandigheden kan schadelijke bijwerkingen van bepalde vormen wan arbeid en/of organisatie reduceren en mogelijk doen werdwinen. Dit wanuit de filosofie dat ieder individu in stat zou moeten en kunnen worden gesteld om overeenkonstig eigen aard, behoeften en ontwikkeling bij te dragen an het arbeidsproces, wardoor zowel vervreending wan het individu van het arbeidsbestel als darmee samenhangende arbeidsbelemmerende psychische en psychosomatische stoornissen zoveel mogelijk kunien worden vookkomen. 


\section{SAMENVATTING}

In dit proefscheift wordt een onderzoek bescheven, dat zich riche op de bepaling van de "instrumentele utiliteit" van een aantal bestaande psychometrische onderzoeksinstrumentem vor de psychologische arbeids(on)geschiktheidsdiagrostiek. Het betreft een analyse van in de praktijk werstrekte psychologische arbeidscon)geschiktheidsadviezen, warbij wordt nagegaan:

- in welke mate psychonetrische onderzoeksgegevens bijdragen tot de classificatie van arbeidsgeschikcen versus arbeidsongeschikten;

- met behulp van welke psychometrische onderzoksinstrumenten de psychologische oordeelsvorming met betrekking tot de arbeidscon)geschiktheid geobjectiveerd en eventueel verbeterd kan worden.

Dartoe heeft een inventarisatie platsgevonden van psychomerische onderzoeksgegevens, welke zijn verkregen van verplich verzekerden, die in de periode 1981-1984 psychologisch $z$ ijo onderzocht op hun psychische belastbaarheid en beroepsvaardigheden. De desbetreffende onderzoeken $z$ ijn uitgevoerd door Psychologisch Adviesbureau Lancée te Alkmar in opdracht van de advies- en uitvoeringsorganen van de arbeidsongeschiktheidswetgewing, respectievelijk de Gemeenschappelijke Medische Dienst (GMD), het Gemeenschappelijk Administratiekantoor (GAK) en het Algemeen Burgerlijk Pensioen fonds $(A B P)$.

Daamast heeft er met medewerking van deze instanties een inventarisatie platsgevonden van de beslissingen, die zij als wetsuitvoerders op basis van de verstrekte psychologische adviezen omtrent de arbeids(on)geschiktheid van de onderzoekspopulatie $(N=804)$ hebben genomen.

Vanuit het gegeven dat 'arbeidsongeschiktheid', zijnde een social-wetcelijk begrip, grotendeels berust op "experts-consensus" is er niet alleen nagegan in hoeverre de verstrekte psychologische arbejds(on)geschiktheidsadviezen ook daadwerkelijk door de opdrachtgevers zijn overgenonen, mar is tevens geanalyseerd in hoevere de daarop gebaseerde beslissingen cot beroepsaken ex: (on)gegrondverklaring darvar hebben geleid.

Door de psychometrische onderzoeksgegevens te relateren am de verstrekte psychologische adviezen en de beslissingen wan respectievelijk de opdrachtgevers, betrokkenen en beroepsinstanties is het mogelijk on door middel wan statistische analyses de voorspellende warde van bepalde psycho- 
metrische onderzoksgegevens woot de arbeids(on)geschiktheidsbeoordeling te bepalen. Op grond darvan kunen en antal (voorlopige) beslissingsragels voor de psychologische arbeids(on)geschiktheidsdiagnostiek worden geformuleed en ean antal psychometrische onderzoeksinstrumenten worden angegeven die in dat verband doeltreffend zijn en kunnen worden gehanteerd.

In het inleidende hoofdstuk wordt na de formulering van het doel en de opbouw van deze studie een korte beschrijving gegeven van het forersisch psychologische referentiekader warbinnen psychologisch onderzoek inzake arbeidscon)geschiktheid plaatsvindt. Vervolgens kont de globale probleenstelling van het onderzoek aan de orde, welke betrekking heeft op de wrag: In hoverre kunnen mensen die in principe op lichamelijke gronden wel arbeidsgeschilkt, mar mogelijk wegens psychische stoornissen niet arbeidsgeschikt zijn, met behulp van psychometrische onderzoeksinstrumenten worden onderscheiden in arbeidsgeschikt en arbeidsongeschikt?

Aan deze probleenstelling worden drie evaluatieve aspecten ontleend, te weten:

le. vaststelling van de predictieve warde van de geinuentariseerde psychometrische onderzoeksgegevens, afzonderlijk en in combinatie, met betrekking tot de psychologische classificatie arbeidsgeschikt versus arbeidsongeschike (psychologische adviezen).

2e. vaststelling van de 'instrumentele utiliteit' (doeltreffendheid) in bredere zin van de gehanteerde psychometrische instrumenten met betrekking tot de psychologische oordeelsvorming inzake arbeids(on)geschiktheid in relatie tot de beshitvorming van de opdrachtgeners, betrokkenen en beroepsinstanties.

3e. vaststelling van (voorlopige) beslissingsregels voor de psychologische arbeids(on)geschiktheidsdiagrostiek.

Deze evaluatieve aspecten komen jn latere hootdstuken uitgebreider aan de orde.

In hoofdstuk 2 wordt vanuit een historisch perspectief het ontstaan van de psychologische arbeids(on)geschiktheidsdiagnostiek beschreven. Mede vanuit het gegeven dat de psychologische arbeids(on)geschiktheidsdiagnostiek zijn 
bestaan ontleent aan de (ontwikkelingen van) arbeidsongeschiktheidswetten, worden deze in een kort bestek besproken.

vervolgens wordt nader ingegaan op de algemene praktijkgang bij de adviesen alvoeringorganen en wordt in grote lijnen thet proces beschreven warlangs deze instanties tot hum oordeelsvorming inzake arbeids(on)geschiktheid komen. In dat verband wordt verder a angegeven welke beroepsmogelijkheden betrokkenen hebben, indien zij het met een beslissing van het desbetreffende uitvoeringsorgan ontrent de arbeids(on)geschiktheidsclassificatie niet eens zijn.

Het hoofdstuk eindigt met een algemeen overzicht van de procesgang bij de arbeidsongeschiktheidsbeoordeling.

In hoofdstuk 3 wordt nader ingegaan op arbeidsongeschikcheid en psychische stoornissen. Na een korte beschouving over de ontwikelungen van de begrippen 'ziekte" en "gebrek' wordt een overzicht gegeven van de sterke coename van her aantal mensen, dat wegens psychische stoornissen de latste jaten arbeidsongeschikt wordt beschouwd. Aan de hand van een literatuurstudie wordt angegeven in hoeverre enerzijds matschappelijke en bedrijfstructurele ontwikkelingen en anderijds 'iatrogene effecten" tot psychïsche staornissen en arbeidsongeschiktheid kunnen leiden.

Daarbij wordt tevens aangegeven welke psychologische persoonskentierken een (medięrende) rol kunnen spelen bij ziekteverzuim en arbeidsongeschiktheid.

In hoofdstuk 4 komen de theorecische achtergronden van de arbeids(on)gem schiktheidsdiagnostiek aan de orde. Uitgaande van het begrip bellasting belastbaarheid is de psychologische arbeids(on)geschiktheidsdiagnostiek gericht op het bepalen wan de functionele relatie tussen eneraija de werkutvoeringseisen van de referentieberoepen en andersijds de individuele psychische belastbarheid erk beroepsuatdigheden. Een verstoorde balars tussen de belasting en belastbaarheid kan leiden tot psychische, fysiologische en gedragsmatige stoornissen. Ahankelijk van hun ard, duur en ernst, kumnen dergelijke stooraissen een reversibel of irreversibel. karakter hebben en kunen daarmee leiden tot respectievelijk tijdelijke of: bli juende arbeidsongeschiktheid.

vervoligens worden de indicatiescellingen voor psychologisch onderzoek inzake arbeidscongeschiktheid geformuleerd. Daabij wordt afhankelijk van 
de vaagstelling onderscheid gemalikt tusen psychodiagnoseisch, psychotechnisch en beroepskeuze-onderzoek.

Het hoofdstuk eindigt met een beschrijuing wan een protocol voor psychologisch onderzoek, dat is gehanteerd bij de beoordeling van de psychische belastbatheid en beroepswardigheden wan de onderzoekspopulatie. In dat verband worden de psychiache belastbarheid en beroepsvardigheden operationeel gedefinieerd als en samengestelde factor, bestaande uit:

- cognitief-intellectuele functies;

- kennis en vaardigheden;

- karakterstructur;

- enotionalitelit en lichamel i.jke gevoelens;

- persoonlijke warden, normen, doelen, instelling en motivatie;

- ariniteitew;

- gedrag en aanpassingswermogen.

Hoofdstuk 5 geeft de opret en uitwoering wan het onderzoek van deze studie weer. Als zijude een 'paramorfe oordeelsstudie', wordt de probleemstelling. ervan gespecificeerd alls: het statistisch analyseren van de wijze warop de psychologische oordeelsvorming inzake arbeids(on)geschiktheid op grond van psychomet $r$ ische gegevens tot stand kom en toekomstige woorspellingen mogelijk zijn. Het onderzoek is dan ook zodanig opgezet, dat er kan worden gezocht naar de relatie tussen de desbetreffende psychometrische onderzoeksbevindingen (psychologische persoonskenmerken) als verklarende en potentieel voorspellende variabelen en de mede daarop gebaseerde psycho$10 g$ ische arbeids(on)geschiktheidsclassificaties als criterium-variabele.

De verklarende variabelen bestara uit 34 psychologische persoonskenmerken, zoals deze met een aantal psychometrische tests, persoonlijkheids- en screeningsuragenlijsten worden gemeten. De criterium-variabele daarbij is de psychologische classificatie arbeidsgeschikt (AG+) versus arbeidsongeschikt (AG-), met als afgeleide criteriumwariabelen de beslissingen van respectievelijk de opdtachtgevers, betrokkenen en de beroepsinstanties.

De onderzoekspopulatie wordt nader beschreven an de hand van de verdeling naar geslacht, leeftijd en opleidingsniveau.

Tenslotte wordt in dit hoofdstuk de methode van dataverzameling angegeven.

Hoofdstuk 6 geeft de resultaten en de discussie weet. Dartuit blijkt dat 
van de cotale onderzoekspopulatie (N = 804) 53\% op psychologische gronden arbeidsgeschikt wordt beschouwd en $47 \%$ arbeidsongeschikt. In het algemeen is er sprake van een goede overeenkomst tussen de psychologische a beids(on) geschiktheidsclassificaties en de beslissingen var de opdrachtgevers.

De mate van overeenkomst tussen de psychologische en verzekeringsgeneeskundige oordeelsworming is voldoende om te spreken van een acceptabele instrumentele waarde van de gehanteerde psychomecrische onderzoksinstrumenten. Dit wordt geadstrueerd door de bewinding dat vergeleken met de jaarlijkse landelijke gegevens daaromtent opwallend minder mensen in beroep zijn gegaan en in geval er toch sprake is geweest van beroepszaken, de meeste ervan ongegrond zijn verklatar.

Het betrekking tot de 'objectiverende' warde van de psychometrische onderzoeksgegevens betreffende de psychologische persoonskenmerken blijkt $85 \%$ een bijarage te leveren an de psychologische classificatie van arbeidsgeschikten versus arbeidsongeschikten. Door middel van een regressie-analyse is vastgesteld dat de psychologische oordeelsworming inzake arbeids(on)geschiktheid is gebaseerd op vier samengestelde componenten. In volgorde van de statistisch geconstateerde gewichtsverlening betreft het de compomenten: psycho-emotionele labiliceit, somatiseren, psychopathologie en performale intelligentie.

Van deze vier componenten hebben, gegeven de psychologische adviezen, alleen psycho-emotionele labiliteit en somatiseren een voorspellende waarde met betrekking tot het beslissingsbeleid van de opdrachtgevers. Van deze vier componenten heeft geen enkele een voorspellende waarde met betrekking tot het kunnen onderscheiden van mensen die well en niet in beroep gaan. Op univariaat niveau is naar voren gekomen dat mensen die in beroep gaan psychisch 'gezonder' zijo dan degenen die niet in beroep gan. Een statistische analyse van de relatie tussen psychologische persoonskenmerken en de beslissingen wan de beroepsinstantieg heeft wegens een te kleine onderzoekspopulatie die in beroep is gegan niet kunnen platsvinden. Wel heeft er van deze specifieke onderzoekspopulatie een kwalitatieve beschrijuende exploratie plaatsgevonder.

In hoofdstuk 7 wordt besproken welke conclusies en aanbevelingen er an de onderzoeksbevindingen kunnen worden verbonden en worden een aancal fvoor- 
lopige) beslissingsegels geformuleerd voor de psychologische arbeids(on)geschiktheidsdiagnostiek.

Vervolgens worden een aantal aanbevelingen gedaan voor een samengesteld psychometrisch onderzoeksinstrumentarium, hetgeen in dit verband kan worden gehanteerd. Daarop aarslutend worden anbevelingen gedaan voor werwolgonderzoek ter ontwikkeling van een standaard psychometrisch onderzoek, dat vanuit zowel wetenschappelijk als rendementsgezichtspun nader op zijn (predictiewe) warde voor de psychologische arbeids(on)geschiktheidsdiagnostiek kan worden beoordeeld.

Tot slot wordt gewezen op het belang van het landelijk hanteren wary een standaard onderzoeksprotocol bij de psychologische arbeids(on)geschiktheidsdiagnostiek en het daarbij op systematische wijze inveatariseren van factoren in het werk en de werksituatie, welke een psychisch ziekmakend effect hebben. 


\section{SHMMARY}

In this thesis a study is described, which is aimed at determining the

"instrumental value" of a number of psychometrie testing instruments for the psychological diagnostics of (in)apacity for work. It is an analysis of psychological recomendations on (in) lcapacity for work which have been given, whereby the following is investigated:

- to what extent psychometric testing instruments can contribute co a classification of persons capacitated for work versus persons incapacitated for work;

- what pychometric testing instruments can help to objectify and possibly improve the psychological assessment of someone's (in)capacity for work. In order to achieve this, an inventory has been made of psychometric testing results which were obtained from persons who had been compulsorily insured, and who had undergone psychological tests of their mentral capacity and occupational competence.

These tests were carried out bij' 'Psychologisch Adviesbureau Lancée' in Alkmar on the authority of the advisory and executive bodies of the incapacity for work legislation, the 'Gemeenschappelijke Medische Dienst" (GMD), the 'Gemeenschappelijk Admintratiekantoor' (GAK) and the "Algemeen Burgerlijk Pensioenfonds" (ABP) respectively.

In adition, these institutions have contributed to the raking of an inventory of decisions, which they have taken in their capacity as executors of the law and which decisions were made on the basis of the psychological recomendations on the (in)capacity for work of the group (N $=804$ ) subjected to this study.

From the fact that "incapacity for work", as a social-legal terro is mainly based on 'experts-consensus', it has not only been investigated to what extent the psychological (inycapacity for work recomendations have actually been followed up by the competent authorities, but it has also been analyzed how many of the decisions based on the recomendations have been appealed and how many of these appeals have been upheld.

By relating the psychometric test results to the psychological recommendations and decisions of the authorities, the persons concerned and the appeal boards respectively, it is possible to determine the predictive wlue of certain psychomeric test results for the assesment of 
(injcapacicy for work by means of statistical analysis. On this basis a number of (provisional) guidelines for the psychological diagnostics of (in)capacity for work can be formulated and number of psychometric test instruments can be indicated which are effective and can be applied in this area.

In the introductory chapter 1 , after the formulation of the objective and the structure of this study, a short description is given of the forensic psychological frame of reference within which psychological testing of (in)capacity for work is carried out. Subsequently a global definition is given of the problem studied, which looks at the question: To what extent can people who, in principle, are physically capable to work, but who are possibly incapacitated for work due to psychological disorders, be distinguished in capacitated and incapacicated for work with the aid of psychometric testing instruments?

Three evaluative aspects are taken form this definition of the problem. These are:

1. determining the predictive value of the psychometric test results which haven been collected, separately and combined, with regard to the psychological classification capacitated versus incapacitated cpsychological recommendations);

2. determining the 'instrumental utility' in a broader sense of the psychometric instruments used with regard to the psychological. assessment of (in)capacity for work in relation to the decision making of the authorities, persons concerned and appeal boards;

3. defining (provisional) guidelines for the psychological diagnostics of (in) capacity for work.

The evaluative aspects are looked into in more detail in subsequent chapters.

In chapter 2 the development of the psychological diagnostics of (in) capacity for work is described form bistoric perspective. party becase of the Eact that the psychological diagnostics of (in)apacity for work exist due to the (developments of) the legislation on incapacity for work, this legislation is discussed in brief.

Subsequently the general practice with the advisory and executive 
authorities is looked into in more detail, and a general description is given of the procedure by which these authorities reach their decision on someone's (in)capacity for work. In connection with this, it is also indicated what possibilities the persons concerned have to appeal if they do not agree with a decision by the executive authorities on the classification of their (in) capacity for work.

The chapter ends with a general outline of the procedure of the assessment. of someone"s incapacity for work.

In chapter 3 incapacity for work and psychological disorders are looked at in more detail. After a short consideration of the development of the terms "sickness" and 'disorder", an outline is given of the great increase that has occurred in recent years in the number of people considered incapacitated for work due to psychological disorders. Whth the aid of a survey of existing literature on the subject, it is indicated on the one hand how developments in society and in business structures, and on the other hand how iacrogenic effects can lead to psychological disorders and incapacity for work.

In addition, it is also indicated what psychological traits may play a (mediating) part in absenteeism and incapacity for work.

In chapter 4 the theoretical background of (in)capacity for work will be explained. Starting from the terms workload - coping, the psychological diagnostics of (in)capacity for work aim at defining the functional. relation between on the one hand the requirements for carrying out the work of the reference occupations, and on the other hand the individual mental. capacity and occupational competence. A disturbed balance between the workload and the ability to cope can lead to psychological, physiological and behavioral disorders, which, depending on their nature, duration and degree, can have a reversible or irreversible character and consequently can lead to temporary or permanent incapacily for work.

Subsequently indicators for psychological testing of (in) capacity for work are formulated, whereby, depending on the question, a distinction is made between psycho-diagnostic, psychomechnical and vocational preference tests.

The chapter is concluded with a description of a protocol for psycho- 
logical testing which is applied in the assessment of the mental capactey and occupational competence of the group studied.

In connection with this, the mental capacity and the occupational competence are operationally defined as a complex factor, consisting of:

- cogritive-intellectual functions;

- knowledge and competence;

- character etruccure;

- emocional and physical feelings;

- personal values, standards, objectives, atcitude and motivation;

- arinities;

- behavior and ability to adapt.

Chapter 5 describes the structure and execution of this study. The definition of the problem is specified as a "paramorphic assessment study" as: the statistical analysis of the manner in which the psychological assessment of (in)capacity for work takes place on the basis of psychometric cest results, and what predictions for the future can be made on the basis of these results.

For this reason the study has been organized in such a way that the rellationship can be investigated between the relevant psychometric test resulics (psychological trajts) as explicative and potentially predictive variables and the psychological (in)capacity for work classification, which is partly based on those cest results, as a criterion variable. The explicative variables consist of 34 psychological traits, measured in a number of psychometric test, and personality and screening questionnaires. the criterion variable in this case is the psychological classification capacitated for work ( $A G+)$ versus incapacitated for work ( $A G^{-}$), with the decisions of the authorities, persons concerned and appeal boards respectively as derivative oriterion wariable.

The group studied is described in more detail with a classification by sex, age and level of education.

Finally, in this chapter the method of data collection is described.

Chapter 6 gives the results and the discussion. This shows that of the cotal group studied ( $N=804), 53 \%$ is considered capacitated for work on psychological grounds and $47 \%$ incapacitated for work. On the whole, there 
is a great deal of agreement betweem the psychological (in)capacicy for work classification and the decisions taken by the authorities. The degree of agreement between the psychological appraisal and medical assessment for the insurance boards is suffichent to talk about an acceptabel instumental value of the used psychometric tests. This is supported by the fact, that un comparison wh national anual figures there is signitcantly lower number of appeals, most of which were disallowed.

With regard to the objectifying value of prychometric test results on psychological traits, $85 \%$ contribute to the psychological classification of capacitated for work versus incapacitaced for work. By using regression analysis it has been determined that the psychological assessment of (in)capacity for work is based on four compllex components. In the order of their statistically ascertained significance these are the components: psycho-emotional instabilicy, somatization, psychopathology and performative intelligence.

of these four components, given the psychological classification, only psycho-emotional instability and somatization have a predictive value with regard to the decision making policy of the competent authorities. Non of these four components has a predictive value with regard to distinguishing between those who do and those who do not appeal.

At univariate level it appeared that those who did appeal were psychologically 'healthier' than those who did not appeal.

A statistical analysis of the relation between psychological traits and the decisions of the appeal boards could not take place because the number of persons that appealed was too small, although a gualitative descriptive exploration of this specific group had been carried out.

In chapter 7 it is discussed what conclusions and recommendations can be drawn from this study and a number of (provisional) guidelines for decision making are formulated for the psychological diagnostics of (in)capacity for work.

Subsequently a number of recommendations are made for the composition of psychometric testing instruments which can be applied in this area. Following that, recommendations are made for further study for the development of a standard psychometric instrument which could be assessed boch from a scientific point of view and from a point of view of its 
practicall functionality on its (predictive) value for the psychological diagnostics of (in)capacity for work.

Finally, the importance of using a standard testing protocol nationally for the psychological diagnostics of (in)capacity for work and investing systematically the factors in work and workcircumstances, which have a psychic disabling effect, is stressed. 


\section{LITERATUUR}

AMSTER, C.W., Mat schappelijke achtergronden van ziek-zijn en zek-moetenzijn.

Medisch Contact $28,1973,690$.

ALGEMEEN BURGERLIJK PENSIOENFONDS, Pensioen en Pensioenfonds Bureau opleiding en Loopbaanbegeleiding A.B.P., Heerlen, 1981.

ALGEMEEN BURGERL IJK PENSIOENFONDS, Jaarverslagen 1981 t.e. m. 1986. Heerlen.

AMERICAN PSYCHIATRIC ASSOCIATTON, Diagnostic and Statistical Manual of Mental Disorders (third edition-revised: DSM-III-R).

Washington D.C., 1987.

ANDRIESSEN J.N.T.H. Interne of externe beheersing. Nederlands Tijdschrift voor de Psychologie 27, 1972, 172-198.

ARGYLE, M., A. FURNHAM \& J.A. GRAHAM, SOcial situations. Cambridge University Press, Cambridge, 1981.

BANDURA, A. Self-efficacy: toward an unifying theory of behavioral change. Psychologicall Review, $84,2,1977,191-215$.

BANEKE, R., De psycholoog in de gezondheidszorg. De Psycholoog, XXII, 1987, 208-209.

BASTELAER, A. van \&W. van BEERS, Organisatiestress en de personeelsfunctionaris.

Swets Zeitlinger B.V., Lisse, 1982.

BASTIAANS, J., Het $k Z$-syndroom en de menselijke vrijheäd. Nederlands Tijdschrift voor Geneeskunde, 1974, 1173-1208.

BAX, E.H., Matschappelijke veranderingen en arbejdsongeschiktheid: de macro-determinanten van WA-toetreding nader verkend.

Ministerie wan Sociale Zaken en Werkgelegenheid, 's-Gravenhage, 1984.

BEEHR, T.A. \& J.E. NEWMAN, Job stress, employee health and organizational effectiveness: a facet analysis, model and literature reviewn

Personnel. Psychology 31, 1978, 665-699.

BEEK, J.L.M. van, De demystificatie van de WAO. Medisch Contact $32,1977,339-341$.

BERGSMA, J., Somatopsycholagie. De Tijdstroom, lochem, 1977.

BERNARDIN, H.J. "The relationship of personality variables to organigation nal withdrawal.

Personnel Psychology 30, 1977, 17-27.

BESAMUSCA-EKELSCHOT, A.T.M., Psychiatrische expertises voor de Rad wan Beroep.

Maandblad Geestelijke Volksgezondheid, 6, 1985, 633-635.

BESSELING, J.J.M. \& H. BRUINSMA, Mannen en vrowwen in en uit de who 1977-1982.

Arts en Sociale Verzekering, jaargang $22,4,1984,938-945$.

BESSELING, J.J.M. \& H. BRUINSMA, Diagnose, geslacht en arbeidsongeschibtheid 1977-1983.

Tijdschrift voor Verzeker ingsgeneeskunde, jaargang 24, 1986, 198-204.

BIDERMAN, A.D. \& Th.F. DRURY (eds.), Measuring work quality for social reporting.

Wiley, New York/London, 1976.

BIEMAN, P.C.M. den, Beroepsrevalidatie door verzekeringsgeneeskundigen.

Tijdschrift voor Verzekeringsgeneeskunde, jaargang 25, 6, $1987,16 \|$.

BIESALSKI, K., Leitfaden der Kruppelfürsorge.

Voss, 1911 . 
BOELEN, J.L.A. S J.J.C.B. BREMER, Verantwoordel ijkheid voor de eigen gezondheid.

Medisch Contact, $23,1987,728-730$.

BOER, E.J., E. VERHAE G Ch.J de WOLE, Stress, uitdaging en bedreiging. Swets or Leitlinger B. vi. Lisse, 1983 .

BodkRTUS, H. Het verhaal van de persoonlijkheid. De herkenbarheid van de individuele persoon in de psychologie: ontwikelingen in de persoonli.jke constructenpsychologie.

Nederlands Tijdschrift voor de Psychologie, 43, 1988, 145-158.

BooN, L., Gegehiedenis van de psychologie. Boom, Meppel, 1984.

Bookden, $1 \mathrm{j}$. de, Zou Coronel nu tevreden zijn? Inagurele rede Rijksuniversiteit limburg.

Tijdschrift voor Sociale Gezondhe idszorg 61, 14, 1983, 487-491.

BOSCH, F.J.A. van den \& C. PETERSEN, De onvang wan de verborgen werkloosheid in de WAO.

E.S.B. $65,3238,1980,52-58$.

BOWLBY, $Y$., The making and breaking of affectional bonds. London, Tavistock, 1979.

BREMER, J.J.C.B., Stress als uitdaging of bedreiging.

In: E.J. Boer, fi. Verhage \& Ch.J. de wolff (red.), Stress, uitdaging en bedreiging. Swets \& Zeitlinger B.V., Lisse, $1983,41-53$.

BREMER, J.J.C.B., De zi iekenhuispatient.

Dekker nan de Vecht, Nijmegen, 1972 , 2e herziene druk.

BROEKHUIS, H., Beoordeling en begelejding bij arbeldsongeschiktheid. Lelystad, 1986.

BRUINSMA, H., Het determinanten-onderzoek WAO. Tijdschrift voor Sociale Geneeskunde 58, 1980, 87-90.

BRUINSMA, H., J. BESSELIMG, G. DIEPENDAAL \& A. JACOBI, WAO-toetreders uit 1985, een beschrijuing; rapport in het kader van het project 'Epidemiologie van arbeidsongeschikten" - thema 'Sociale Indicatoren". GMD-cahier or. 12, Amsterdam, 1987.

BRUYN, E.E. I. de, Besluitworming in de kl inische psychodiagnostiek. Nederlands Tijdschrift voor de Psychologie, 43, 1988, 263-279.

BUIS, H.A.M., De positie van de GMI als informatie verschaffende en ondersteunende instantie in de beroepsprocedures ingevolge de Beroepswet. GMD, Ansterdam, 1986 .

BuIS, H.A.M." De oncwikkeling van het begrip 'ziekte of gebrek" in de literatur en de jurisprudent ite.

Tijdschrift voor Verzekeringsgeneeskunde, jalargang 24, $1986 \mathrm{~b}, 134-136$.

BuYs, P.C., Curatieve gezondheidszorg, ziekteverzuim en arbeidsongeschiktheid.

Universiteit van Ansterdam, 1984.

BTJLSMA, T. \& F. KOOPMANS, De uitbreiding van het ziektebegrip en de wAO. Sociaal Maandblad Arbeid, 1982, 803-819.

CALDENBORGH, P.H.M.J. wan, J. van der GRTEND \& A. HOUBEN, Beroepsrecht. Nascholingsprograng GMD, Ansterdam, 1985.

CAPLAN, G., Priaciples of preventive psychiatry.

Basic Books, New York, 1964.

CAPLAN, R.D., S. COBB, J.R.P. FRENCH, R. van HARRISON \& S.R. PLNNEAU, Job demands and worker health: main effects and occupational differences. Hew Publications, Nosh, 1975, 75-160.

CENSE, W.H. Wetgeving patientenrechten en de dokter.

Medisch Contact, $40,1987$. 
CENTRAL BUREAU voor de STATISTIER, De leefsicuatie van de Nederlandse bevolking - kerncijters.

's-Gravenhage, 1983.

CHADWICK-JONES, J.K., C.A. BROWH, N. NLCHOLSON, Absence from work: ìts meaning, measurement and control.

International Review of Applied Esychology 22, 1973, 137-154.

CHAMBERS, W.N. \& H.F. REISER, Conjestive heart fallure. Psychosonatic Medicine, 15, 1953, 39-60.

ClARK, I., Time out? A study of absentee ism among nurses. Royal Nat, council nurses of the U.K., London, 1975.

GLEEN, M.A.E.J. de, De warde van een psychoilogisch adviesbureau voor het verzekeringsgeneeskumdig handelen.

Stichting woor Socialle Gezondheidszorg te Utrecht, januari 1985.

COOPER, R. \& R. PAPNE, Extraversion and some aspects of work behawior. Personnel Psychology 20, 1967, 45-57.

DAHLSTROM, W.G., G.S. WELSH \& L.E. DAHLSTROM, An MMPT handbook, Vol. 2: research applications.

University of Minnesota Press, Minneapolis, 1975, revised edition.

DANIELS, Mc., Onaangepastheid in de werksituatie. Nijmegen, 1958 .

DASSEL, H., Sociale factoren en invaliditeit Pre-advies III, Arts en Sociale Verzekering, 8, 1970, 93-107.

DECHESNE, B.H.H. \&.L.J. BUYS, Kinderrevalidatie. De ondwikkeling van een idee.

Nederlands Tijaschrift voor de Psychologie $38,1983,173-188$.

DEFARES, P.B., Socialisatie, adaptatie en stress.

Van Gorcum, Assen/Amsterdam, 1976 .

DEFARES, P.B. \& F. VERHAGE, Omgaan met stress.

In: E.J. Boer, F. Verhage \& Ch.J. de Wolff (red.), Stress, uitdaging en bedreiging. Swets \& zeitlinger B.W., Lisse, 1983, 87-104.

DINGEMANS, P., H. van ENGELAND, J.H. DIJKHUIS \& J. BLEEKER, De 'diagnostic interview schedule' (DIS).

Tijdschrift voor Psychiatrie 27, $1985,341-359$.

DIRKEN, J.M., Vragenlijst voor Onderzoek van de Ervaren Gezondheidstoest. and.

Wollers-Noordhoff, Groningen, 1967.

DRAATSM, D. \& P.G.W. SMULDERS, Ziekteverzuitm en het bedrijf. NIPG-TNO, Leiden, 1978.

DRENTH, P.J.D., De psychologische test. Van Loghum Slaterus, Dewenter, 1975.

DRENTH, P.J.D., H. THIERRY, P.J. WLLLEMS C Ch.J. de WOLF, Handboek Arbeids- en Organisatiepsychologie it en Ir. Wan Loghum Slaterus, Deventer, 1984.

DROGENDIJK, A.C.\&J.F. RANG, De onderzoeksduldingsplicht. Tijdschrift voor Sociale Geneeskunde, 44, 1966, 909-914.

DI.JK, F.J.H. van, D.A. Wan HASELEN, D.E. LENSHOEK, P. HELLINGA, S. de BOER \& C. KOFFEMAN, WAO-toetreding: Trends en risicogroepen in een groot industrieel bedrijf.

Tijdschrift voor Sociale Gezondheidszorg, 65, 1987, 654-662.

DIJKHUIZEN, N. van, from stressors to strains.

Swets \& Zeitlinger B.V., Lisse, 1980.

DIJKSTRA, A., Determinanten van ziekteverzuim in produktie-morganisaties voor gehand icapten.

NIPG-TNO, Leiden, 1977. 
EMAMUL, H, Het deterninantenonderzock WO. Voordracht NWVG-studiemidag mart 1986.

Tijdschrift woor Verzekeringsgeneeskunde, jaargang $24,1986,152-158$.

EPKER, W.H., Verzekeringgeneeskundigen en curatiewe zorg.

Medisch Contact, 43, 1987, 1367-1370.

EYCK, J.H.M., De angsten van arbeidsongeschikten.

Medisch Contace, 8, 1982, 223-226.

FARR, J.R., Response requirement and primacy-recency effect in a simulaced relection interview.

Journal of Applied Psychology, 57, 3, 1973, 228-232.

FESTRGER, L., A theory of cognitive dissonance. Euarston, Mllinois: Row, Peterson, 1957.

FLEISS, J.L., Measuring nominal scalle agreement among many raters. Psychological Bulletin, 76, 197》, 378-382.

EOROYCE, W.E., Behavioral methods for chronic pain and illness. Mosby Compagny, St. Louis, 1976.

FREUD, $S$, Intibitions, symptoms and anxiety. Hogarth Press, Standard Edition 20, London, 1926.

FRTJLING-SCHREUDER, E.C.M., Medische begeleiding van de psychische ontwikkel ing van het kind; goedkope preventie.

Nederlands Tijdschrift voor Geneeskunde 114, 1970, 1080-1085.

GALAN, C. de, M.R. van GILS \& P.J. van STRIEN (red.), Humanisering wan de arbeid.

Van Gorcum, Assen, 1983.

GEMEENSCHAPPELIJKE MEDISCHE DLENST, Jaarverslagen $1981 \mathrm{t} . \mathrm{e} . \mathrm{m}$. 1986. Amsterdam.

GERSONS, B.P.R., Werkstress: Opvang en behandeling. Medisch Contact, 43, 1987, 1363-1366.

GIEL, R. Het dilema van de medische beroepsuitoefening.

Medisch Contact, 31, 1976, 1021-1026.

GLEL, R., Waarom een psychiatrische diagnose? Samson Stafleu, Alphen a an de Rijn, 1985, 2e druk.

GLER, H.G. de, Arbeidsongeschiktheid onderzocht: de beteken is van onderzoek nat arbeidsongeschiktheid woor het sociale zekerheidsbeleid.

Sociaal Maandblad Arbeid, 36, 1981, 804-813.

GLASS, D.C., Behavior patterns, stress and coronary disease.

Lawrence Erlbaum, New Jersey, 1977.

GOLDMAN, H.H., Review of general psychiatry.

Lange Medical Publications, Los Alcas, California, 1984.

GKANDJEAN, E., Fitting the task to the man, an ergonomic approach. London, 1982 .

GREENL, R.L., The MMPI; an interpretive manual. Grune \& Stration Inc., New York, 1980.

GROENMAN, N.H., Gedragskunde en chronische pijn.

In: B.C. Deelman, P.M.G. Emuklkamp, A.F. Kalverboer \& F. Luteijn

(red.), Ontwikkelingen in de $\mathrm{kl}$ in ische psychologie. Van Loghum Slaterus B.V., Deventer, 1986.

Gkoot, A.D. de, Methodologie: Grondslagen van onderzoek en denken in de gedragswetenschappen.

's-Gravenhage, 1972, 7e druk.

GROOL, M.J.W. de, Kwantitatieve benadering van het verzuim door neurosen bij Nederlandse fabrieksarbeiders.

NIPG-TNO, Leiden, 1958, $111-120$. 
GROOT BLUEMTNK-van WIJK, J.M.E.A., H.E.C. HOEFSLAG, C. van der MAREL, E.M.E. v.d. WERF-HUYSMANS \& $S$. Wan der ZEE, Neuroticisme en arbeidsongeschiktheid.

Stichting voor Sociale Gezondheidszorg, Utrecht, 1982.

GROOTHOFF, J.W., Gezondheidszorg en 3-maands verzuingevalien.

Tijaschrift woor Sociale Geneeskunde $59,2,1981,81-83$.

GROOTHOF, J.W., Gezondheidstoestand van de beroepsbevolking. Fen studie naar de indicatoren arbeidsongeschiktheid, sterfte en gezondineid. Van Denderen B.V., Groningen, 1986.

GROSEELD, J.A.M., De voorspelbatheid van individuele verzuimduur. Swets \& Zeitlinget B.V., Amsterdam, 1988.

HAkK, J.C., De re integratie van de gehandicapte in het arbeidsleven.

In: A. Nap e.a. (red.), Validiteitsonderzoek. Stafleu, Leiden, 1970.

HARRIS, R. \& J. LINGOES, Subscales for the Minnesata Multiphas ic

Personality Inventory, mimeographed materials.

The Langley-Porter Clinic, 1955.

HAVERKAMP, N.J. Kanttekeningen bij de coepassing van de zorgvuldigheidsnorm in enkele witspraken van de Crentrale Raad van Beroep.

Sociaal Maandblad Arbeid, $1982,598 \mathrm{e.v}$.

HAZENWINKEL, A., Wat is stress?

In: Nederlandse Vereniging voor Bedrijfspsychologie 77, Omgan met stress in de organisatie. Kluwer, Deventer, 1984 .

HEETEN, W. den, H. KAAX, P. van VEEN \& T. VERSCHUREN, Preventie van ongeschikte arbeid. Visie en aabevelingen vanuit de preventieve ambulante geestelijke gezondheidszorg.

Hoo Fiddorp, 1988.

HERMANS, P. C*, De positie van vrouwen bij de uitvoering van de arbeidsongeschikthe idswetten.

Tijdschrift voor Verzekeringsgeneeskunde, jaargang $26,3,1988,93-96$.

HERREMA, T., Over Revalidatie: Psychologische aantekeningen over de revaLiciatie van door een ongeval getroffen arbeiders.

Van Loghum Slaterus, Arnhem, 1959.

HIBBELN, J.G., Onderwerp van de in de WAO verwatce verzekering,

In: A. Nap e.a. (red.) Validiteitsonderzoek. Stafleu, Leiden, 1970 , $370 \mathrm{~m}: 4 \| 1$

HIBBELN, J.G., Is de verzekeringsgedachte achterhaald?

Tijdschrift voor Sociale Geneeskunde 18, 1980, 209-212.

HILVERINK, H.G., Arbeidsongeschikt of arbeid ongeschikt?

In: Arbeidsongeschiktheid: enkelle invalshoeken. GMD, Amsterdam, 1977.

HUNKLE, L.E. \& N. PLUMMER, Life stress and industrial absentedism.

Industr. Med. Surg., 21, 1952, 363-375.

HOENCAMP, E. \& SCHPPER, J.A., Psychiatrische expertises voor de Raad van Beroep.

Maandblad Geestelijke Volksgezondheid, I, 1985, 3-18.

HOENCAMP, E. K. RIJNHART, Psychiatrische criteria in relatie tot arbeidsongeschiktheid.

In: E. Hoencamp e.a., Rapportage en de sociale wetgeving. De nietstrafrechtelijke forensisch psychiatrische en psychologigche beoordeling. Gouda Quint B.W., Arnkem, 1988, 45-61.

HOFFMA, P.J., The paramorfic representation of clinical judgment.

Psychological Bulletin, 57, 1960, 116-131.

HOFSTEE, W.K.B., Psychologische witspraken over personen.

Van Loghum Slaterus, Deventer, 1981. 
HOFSTEE, W.K.B., F.B. BROKKEN \& H. LAND, Constructie yan een Standard Persoonlijkheids-Eigenschappen-Lijst (SPEL).

Wederlands Tijdschrift voor de Psychologie, 36, 1981.

HOFSTEE, W.K.B., What's in a trait: reflections about the inevitability of traits, their measurement and taxonomy.

In: H. Bonartus, G. wan Heck ow. Smid (eds.), Personality psychology

in Europe, Vol. I: Theoretical and empirical developnents. Swets \& Zeitlinger B. W. Lisse, 1984 .

HOLTHUIS, R., Bedrijesgeneeskunde. Amsterdam, stichting CCOZ, 1980 a.

HoL.shUIS, R., Verzekeringsgeneeskumde. Arrsterdat, stichting CCOZ, 1980 .

HOROWITZ, M.J., Stress response syndromes. Aronson, New York, 1976.

HORST, L. van der, Rapport over het begrip psychische ziekte. Centrale kad van Beroep, 1953 (30 juni, 2W 1951/207 en 1952/46).

HOUBEN, A.H.G.M., De psychiatrische rapportering in beroepsprocedures over geschillen betreffende arbeidsongeschiktheid. Voordracht op de najaarsvergadering van de Nederlandse Vereniging voor Verzekeringsgeneeskunde. Tijdschrift voor Sociale Gezondheidszorg, 17, 1984, 688-690.

HOWELL, R.W.\& S. CROWN, Sickness absence levels and personality inventory scores.

Brit.J.Industr. Med. 28, 1971, 126-130.

HUBBEN, J.H., Medisch tuchtrecht en geestelijke gezondheidszorg. Maandblad Geestelijke Volksgezondheid 2, 1987, 123-146.

HULLENAAR, R.H.J. van 't \& D.B.J. KONJ NGSVELD, Afgebrand of afgedankt; een onderzoek naar oorzaken van arbeidsongeschiktheid.

Swets Zeitlinger B.V., Lisse, 1986.

HUNFELD, G. Interne GMD publicatie. Amsterdam, 1980 .

HYMANS wan den BERGH, A.A. \& J.M. BAART de la FAILLE, Rapport over het begrip ziekte.

Centrale Rad van Beroep, 1936 (24 mart, ZW 1935/79).

ILGEN, D.R. \& J.H. HOLLENBACK, The role of jobsatisfaction in absence behavior.

Organizational behavior and human performance 19, 1977, 148-161.

ILLICH, I., Het medisch bedrijf - een bedreiging voor de gezondheid? Wereldvenster, Baarn, 1975 .

JACOBS, M.A., A.Z. SPILKEM, M.M. NORMAN \& L.S. ANDERSON, Life stress and respiracory illness.

Psychosomat ic Medicine, $32,1970,233-243$.

JANSEN, B., Dagdienst en ploegendienst in vergelijkend perspectief. Swet \& Zeitlinger B.W., Lisse, 1987.

JANSEN, I., W.H.C. KERKHOFF \& M.J. VLELVOYE, Persoonlijkheidskenmerken en arbeid.

Tijdschrijft voor Verzekeringggeneeskunde, 25, 1987, 102-105.

JANEI, P., Les abessions en la psychasthénie.

Alcan, Paris, 1903.

JONG, Ph. de, H. BRUINSMA, L. AARTS \& J.P. HOP, Determinanten-onderzoek WAO, Fase I, determinanten van WAO-toetreding: een eerste totalbeeld. Zoetermeer/Leiden, $198 \|$. 
JONG, A. de, R. GIEL, C.J. SLOOFEEN \& D. WLESMA, Sociale beperkingen ten gevolge wan functionele psychosen. Het ontwerp wan een model voor de ontwikkeling van sociale beperkingen.

Tijdschrift voor Sociale Gezondheidszorg, 61, 1983, $78-85$.

JoNG, A. de, Over psychiatrische invaliditeit, ean theoretische mpinische verkenning nat het verband tussen psychitutische ziekce en social gedrag.

Van Denderen B.V., Groningen, 1984.

JONG, E.P., Het administratieve procesrecht wolgens de Beroepswet.

Uitgave Vermande, IJnuiden, 1984.

JONGERIUS, J.A.C., Decompensatie: draglast en dragkracht in relatie tot decompensatie bij meurastheen syndroom.

Uitgeversmatschappij Huisartsenpers B.V., Utrecht, 1984.

JONGH-HYLKEMA, J.T.O. de, Maatschappelijk werzuim in cijfers.

Tijdschrift voor Sociale Geneeskunde 51, 1973, 215-222.

KABELA, M., Psychiater en arbeidsongeschiktheid.

Medisch Contact, jaargang $41,51 / 52,1986$.

KABELA, M., Psychiatrische rapporten.

Tijdschrift voor Psychiatrie, $29,3,1987$.

RABELA, M, Psychiatrisch oordeel beoordeeld. De psychiatrische beoordeling van arbeidsongeschiktheid.

Swets \& Zeitlinger B.V., Lisse, 1988.

KABELA, M. \& W.H.J. LANCEE, Protocol voor psychiatrisch en psychologisch onderzoek inzake arbeids(on)geschiktheid.

In: E. Hoencamp e.a., Rapportage en de sociale wetgeving. De niet-strafrechtelijke forensisch psychiatrische en psychologische beoordeling. Gouda quint B.. ., Arnhem, 1988, 33-43.

KAHN, L. Some propositions toward a researchable conceptualisation of stress.

In: J.E. Mo.Grath (eds.), Social and psychological factors of stress. Holt, Rinehart \& Winston, 1970, 97-104.

KALSBEEK, J.W.H., Mentale belasting. Academisch proefschrift, Amsterdan, 1967.

KAMPHUIS, A., Mentale belasting: theorieèn en modelien. PTT - SWO 1, Rapport 595/1, Den Haag, 1977.

KAPLAN, H.I. \& B.J. SADOCK, Modern synopses of comprehensive textbook of psychiatry, IIT.

Williams and Wilkens Company, Baltumore, 1981.

KASL, S.V., Epidemiological contributions to the study of work and stress. In: C.L. Cooper \& R.L. Payne (eds.), Stress and work. Wiley, New rotk, $1978,3-48$.

KLEBER, R.J., Stressbenaderingen in de psychologie.

Van Loghum Slaterus, Deventer, 1982 .

KLEBER, R.J., D. BROM \& P.B. DEFARES, Traumatische ervaringen, gevolgen en verwerking.

Swets \& Zeitlinger B.V., Lisse, 1986 .

KLETNBAUM, D.G., L.L. KUYPER \& H. MORGENSTERN, Epidemiollogic Research: Principles and quantitative methods.

Van Nostrand Reinhold Company, New York, 1982.

KLERK, J.M. de, C.J. PETERSEN \& G.C. DIEPENDAAL, Diagnosecategorie V: psychische stoornissen en de WAO; een nadere beschrijving.

Arts en sociale verzekering, $2,1983,334-440$. 
KLERK, J.H. de, G.C. DLEPENDAL \& C.J. PETERSEN, Psychische staornissen en arbeidsongeschiktheid.

Tijdschrift voor Verzekeringsgeneeskunde, jaargang 24, 1986, 136-142.

KNEPPER, S., Een analyse van 500 schat ingszalken AAH/WAO vonor de Raad van Beroep.

Stichting voor Sociale cezondheidszorg, verecht, 1983 .

KNEPPER, $5 .$, De psychiatrische arbeids(on)geschihtheidsbeoordeling voor de administratieve rechtet. Voordracht op de Najaarsvergadering van de Nederlandse Vereniging voor Verzekeringsgeneeskunde.

Tijdschrift voot sociale Gezondheidszorg, 17, 1984, 681-684.

KNEPPER, S., Psychiatrische expertises voor de Raad van Beraep. Maandblad Geestel ijke Volksgezondheid, 3, 1985, 289-290.

KNEPPER, $\mathrm{S}$. Het deskund igenrapport in de verzekeringsgeneeskunde.

Nederlands Tijdschrift voor Geneeskunde, 22, 131, 1987, 938-942.

KNEPPER, S., GMD Jaarverslag 1986 nader beschouwd.

Medisch Contact, 43, 1987, 1370-1372.

KNEPPER, S. \& A. den OUDEN, Beschouwing van de niet-strafrechtelijke Corensische psychiatrische en psychologische beoordeling.

In: $\mathbb{E}^{2}$. Hoencamp e.a., Rapportage en de sacialle wetgeving. De nietstrafrechtelijke forensisch psychiatrische en psychologische beoordeling. Gouda quint B.V., Arnhem, 1988, 63-74.

KNIPPENBERG, $A$. van \& F. STERO, Multiwariate analyse. Van Loghum S1aterus, Deventer, 1986.

KOELE, P., H. BERENDS \& S. GOOZEN, Judgenent analysis in a clinical setting: a casestudy im policy capturing.

Afdeling Methodologie, Universiteit van Ansterdam, 1987.

KOENRAADT, E. M. PACH, Plaatsbepaling van forensisch psychiatrisch en psychologisch onderzoek.

In: E. Hoencamp e.a., Rapportage en de sociale wetgeving. De nietstrafrechtelijke forensisch psychiatrische en psychologische beoordeling. Gouda quint B.V., Arrhem, 1988, 9-19.

KOMPIER, M., T. METJMAN, H. MULDERS \& R. BULLINGA, Onderzoek nat de relatie tussen ziekteverzum en arbejdsongeschiktheid bij stadsbuschauffeurs.

Tijdschrift voor Sociale Gezondheidszorg, 64, 1986, 477-480.

KONING, R., Psychiatrische diagnose per computer.

Psychologie en Computers, Jaargang 4,2 , wIP/Swets \& Zeithinger B.V., 1987.

KOOPMAN-IWEMA, A.M. \& S. WIEGERSMA, SOC ile arbeidspsychollogie. De Toorts, Harleri, 1985.

KOOREMAN, A. F. GROOT, Registratie Scholing, 1981-1983. GMD, Ansterdam, 1984 .

KOOREMAN, A. \&H. BERK, Is een nadere differentiatie van het ARBI-beroepsniveau halbar met een checkllist?

Beroepskeuze, tijdschrift voot school-, studie- en beroepskeuzewoorlichting, jaargang $34,2,1987,86-94$.

KOOREMAN, A. \& I. LUTEIN, Groninger Intelligentie Test; schriftelijke verkorte vorm.

Swets \& zeitlinger B.V., Lisse, 1987.

KoRTMANN, F.A.M., Moeilijkheden bij de beoordeling wan arbeidsongeschiktheid wegens eem psychiatrische ziekte.

Thjdschrift voor Sociale Gezondheidszorg, 5, 1987, 136-138. 
ROTEN, J.W. S M. TIMER, Werzekeringsgeneeskunde als medebeheerder van de A.W/GAO.

Tijdschrift woor Sociale Geneeskunde, $60,1982,777-784$.

KOTEN, J.W., Arbeidsgeneeskundige thema's: zenuwvermoeiende werkomstandigheden (delen I, II en IIT).

Tijdschrift woor Verzekeringsgeneeskunde, jaargang $23,1985,18-21$, $43-51,82-85$.

KOTEN, J.W. \& M. TTMMER, stoornissencahiers.

GMD, Ansterdam (in press).

KRAFT, Th. B., Overspanning.

Bohn, Haarlem, 1972.

KRAFT, Th. B., Overspanning en arbeidsongeschiktheid.

Arcs en sociale Verzekering, 13, 1975, $44-49$.

KROEZEN, M. \& T. WIND, Hulpverlening aan arbeidsongeschikten.

Arbeidsongeschiktheid en psychosociale problematiek. Vakgroep Ki inische Psychologie, Rijksuniversiceit Groningen, 1983, 131-139.

KROODE, H.F.J. ten, Psychollogische onderzoekingen van rugpijn.

Medische Psychologie, Rijksuniversiteit van Wtrecht, 1982 .

KRUIDENIER, H.J., Het ontbrekende alternatief. Een onderzoek naar de persoons- en functiekenmerken van WAO-toetreders.

Amsterdam, CCOZ, 1980.

KRUITHOF, W., G. GODAERT \& D. SCHREURS, Psychosomatiek: visies, modellen en theorieèn.

Metamedica, $57,1978,243-253$.

KUTLMAN, M. , De psychosociale anamnese. GMD, Ansterdam, 1978.

KUILMAN, M., Psychotherapie en arbeidsongeschiktheid.

Lezing studiedag Sectie Psychotherapie voor de Nederlandse Vereniging van Psychiatrie te Harlem, 1982.

KUILMA, M., Over de patient die het niet zag zitten; dilema's voor het bedrijfis-en verzekeringsgeneeskundig handelen.

Tijdschrijft voor Sociale Gezondheidszorg, 16, 63, 1985, 704-7॥1.

KUIPER, J.P., Een gezondheidkundige kijk op de mens-arbeidrelatie.

In: C. de Galan, M.R. van Gils, en P.J, van Strien (red.), Humanisering var de arbeid. Van Gorcum, Assen, 1983, 181-216.

KWANT, R.C., Rilosofie van de arbeid.

De Nederlandse Boekhandel, Ancwerpen, 1864.

KWEE, S.H., De rol van de vaste deskundige bij de Raad van Beroep.

Scriptie in het kader van de cursus verzekeringsgeneeskunde, ut recht, 1980.

LACHAR, D., The MMPI: Climical Assessment and Automated Incerpretation.

Western Psychological Services, Los Angellos, 1985.

LAMBERT, H. LUTEIJN, E. De vergelijking van de NVM en de MMPJ in de klinische praktijk: instrumenteel onderzoek.

Nederlands Tijdschrift woor de Psychologie, jaargang 42,2 , 1987, $81-85$.

LAMMERS, C.J., Uiterlijke samenhang en bindingskracht van de organisatie. Oratie, Assen, 1964.

LAMCEE, W.H.J., Gedragsmodificatie in een school voor buitengewoon onderwijs.

In: J. de Wit, H. Bolle or J.M. van Mee] (red.), Psychologen over het kind 4. H.D. Tjeenk Willink, Groningen, 1976. 
LAWCE, W.H.J., Revalidariepsychologie een specialisme?

Inlaiding Wajarsconferentie Werkgroep Revalidatie Psychologen, Ml. Amsterdam, 1979.

LANCE, W.H.J., Interdisciplinaire samenterking in de revalidatie: conflictsituaties en conflicthantering.

Inleiding Basiscursus Revalidatie 1979-1980; Institut voor Revalidacie, Erasmus universiteit, Roterdam, 1980.

LANCE, H.H.J., Leerpsychologie in de revallidatie. Alkmar, 198 la.

LANCEE, W.H.J., Revalidatie en arbeid.

Bedrijfsgezondheidszorg, jaargang $34,1981 \mathrm{~b}, 18-23$.

LANCEE, W.H.J., Onderzoekstechnieken voor arbeidsrevalidatie. 1981 (niet gepubliceerd).

LANCEE, W.J., Vragen aan de psychologie over de grenzen van de bedrijfsgeneeskunde heen.

Inleiding glotsymposium van de lle cursus Arbeids- en Bedrijfsgeneeskunde, Nijmegen, 1983.

LANCEE, W.H.J., Het overbelastingssyndroom.

In lejding Werkgroep Deskundigheidsbevordering Huisartsen, Alkmarse artsencursus, Den Helder, 1988.

LANCEE, W.H.J., Chronische pijn en arbeidsongeschiktheid.

In: N.H. Groenman (red.), Chronische pijn, psychologische diagnostiek en operante behandeling (in press).

LAZARUS, R.S., Psychological stress and the coping process. Pacterns of adjustment,

MCGraw-Hill, New York, 1976 .

LEEEEN, H.J.J., Juridlische aspecten van medische keuringen.

Nederlands Juridisch Blad, 1980, $1082-1089$.

LEEST, P, van, Ontwikkelingen binnen intelligentie. Psychologie en Computers, jaargang 4, 2 , NIP/Swets \& Zeitlinger B.V., Ansterdan/Lisse, 1987.

LE SHAN, L.L. \& R.E. WORTHINGION, Loss of cathexes as a common psychodynamic characteristic of cancer patients: an attenpt at statistical validation of a clinical bypothesis.

Psychological Reports, 2, 1956a, 183-193.

LOESER, J.D. \& W.E. FORDYCE, Chronic Pain. Behavioral science in the practice ố medicine.

Ellsevier Biomedical, Amsterdam, 1983.

LOKANDER, S. \& M. MACHL, Sick absence in de Swedisch company. Part 4. The relationship between absence due to sickness and psychological status. Acta Psychiat. Scand. $40,1964,401-418$.

LUTEIJN, F. \& L. KINGMA, Een nieuwe verkorte MMPI. Hederlands Tijdschrift voor de Psychologie 34, 1979, 459-471.

LUTEIJN, R., D.R. KOK \& E.A.E. van der PLOEG, Handleiding bij de NVM. Swets \& Zeitllinger B.V., Lisse, 1980.

LUTELIN, $F$, J. STARREN \& H. Van DIJK, Handleiding bij de NPV. Swets \& Zeicllinger B.V., Lisse, 1985.

MAAS, P.d. van der, Arbeidsverzuim en arbeidsongeschiktheid in verband met psychische afwijkingen; hebben medische diagnoses enige betekenis in de wereker ingsgeneeskunde?

Arts en Sociale verzekering, 1975, $24-35$.

MACKENBACH, J.P. \& M. ENGELS, Regionale gezondheidsverschillen. NTPG-TNO, Leiden, 1984. 
MANEN, N.F. wan, De watergate wan het beroepsgehein. N.J.B., $1978,453-456$.

MANOURY, J. J.P. ASSCHER-VONR, Hoofdtrekken van de sactale verzekering. Tjeenk Willink, Alphen aan de Rijn, $1987,2 e$ druk.

MANSVELT, J. van, Een onderzoek naar de oorzakelijke factoren en bijzondere kennerken bij het langerdurend arbeidsverzuim. Medisch Contact, $30,1975,79-81$.

MENGES, L.J., Gezondheid en ziekte, gedragswetenschappelijke verkenthinen. Samson Stafleu, Aphen aan de Rijn, 1986.

MERENS-RIEDSTRA, H.G., Leven zonder werk; een saciaal-wetenschappelijk onderzoek nat arbeidsongeschiktheid.

Rijksuniversiteit Limburg, Maastricht, 198 .

MERTENS, A.Th.L.M. \& J.C. STRENG, Eindwerslag werkatheden comissie "Bestudering Ontwikkeling Ziekteverzuiru" . Sociale Verzekeringstaad, Zoetermeer, 1981.

METJMAN, T.F., Stress op de werkvloer. Veiligheid, 60, 1984, 547-550.

MEYMAN, T.F. \& J.F. O'HANLON, Arbeidsbelasting: een inleidend overzicht van de psychologische theorieen en meetmethoden.

In: P.J.D. Drenth e.a. (red.), Handboek arbeids- en organisatiepsychologie. Van Loghum Slaterus B.V., Deventer, 1984.

MOESROPS, H.A.M., De beroepsclassificatie. Sociaal Maandblad Arbeid, 1948, 64-69.

MOORE, J.E., M.E. MC.EALL, D.R. KIVLAHAN \& E. CAPESTANX, Risk of misinterpretation of MMPI schizofrenia scale elevation and chronic pain patients. Pain, 32, 1988, 207-213.

Moorz, M., De patiënt en zijn nasten. De invloed van houdingen in het persoonlijke netwerk wan de patiët op zijn medische consumptie. Pasman B.W., 's-Gravenhage, 1981 .

MUCHINSKY, P.M., Employee absentee ism. A review of the literature. Journal of Vocational. Behavior 10, 1977, 316-340.

MUNTENDAM, P., VijEtig jaar Ziektewet. Medisch Contact, 9, 1980, 277-279.

NEDERLANDS INSTITUUT WAN PSYCHOLOGEN, Beroepsethiek voor psychologen. Ansterdam, 1987.

NISBETT, R. \& L. ROSS, Human inference: strategies and shorteommings aE social judgment.

prenticewall, Englewood Cl iffs, New York, 1980 .

NUNNALLY, J.C., Psychiatric theory. Mc.Graw Hill, New York, 1978.

Nutrin, J. \& B. BEUTEN, Handleiding bij de persoonlijkheidsinventaris Mpl. Universitaire uitgaven, Leuven, 1969.

MIJHUIS, F" \& J. SOETERS, werk en ziekte. Een onderzoek naar a fwezigheid wegens ziekte en arbeidsongeschiktheid bij 51 industriele en niet-industriële organisaties in zuid-Limburg. Mastricht, 1982 .

NIJHULS, F. Beoordelingen van organisatiekenmerken. Rijksuniversiteit Limburg, Mastricht, 1984.

OLST, E.H. wan, A. KOK \& J.F. ORLEBERE, Inleiding in de psychofysiologie. Van Loghum Slaterus, Devencer, 1980.

OOSTEROM, A. van, De bedrijfsarts en stress in de arbeid. In: Nederlandse Vereniging voor Bedrijfspsychologie 77, Omgan met stress in de organisatie. Kluwer, Deventer, 1984. 
ORYEL, H., Moeite met lewen of een moeilijk leven. Een vervolgonderzoek naar de hinloed van psychosociale belasting op het welbevinden wan drithonderd Nederlanders.

Tijdgchtift voor Socialle Gezondheidszorg, jaargang 6, 1, 1985, 22-29.

OUDENDLJK, C., Sociale attas van de wouw 1983. Social en Cultureel. Planbureau, "s-Gravenhage, 1983.

PANHITS, P.J.A. van, Ziekte en/of gebrek in de psychiatrie. Tijdschifc woor Sociale Gezondheidszorg $65,14,1987,467-471$.

PARDINE, P., HIGGNS \&. SZEGLIN, Job-stress workerstrain relationship moderated by off-the-job experience.

Psychol. Resp. 48, 1981, 963-970.

PAS, J.H.R. Van der, Arbeidsongeschiktheidscriteria: van ongevallenwet naar arbejdsongeschikcheidswetcen.

Social Matndblad Arbeid, 7/8, 1978.

PHLLPSEA, H. Afwezigheid wegens ziekte; een onderzoek natar oorzaken van verschillen in ziekteverzuirm.

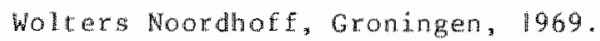

PHTLPSEN, H., Het medisch oordeel: besliskunde of speltheorie. Tijaschrift voor Sociale Geneeskunde, 57, 1979, 838-842.

PLOEG, H.M. van der, P.B. DEFARES C.D. SPTELBERGER, De Zelf-Beoordelings Vragenlijst, $\mid 981$.

PLOOY, J., Litarature en jurisprudentieregister/rechtspositie van de medische keurling.

Wi.llem Pompe Institud woor strafrechtswetenschappen: sector forensische psychiatrie en psychologie, Universiteit van utrecht, 1985.

POLAK, B.S., Het begrip ziekte in de zin van de Ziektewet. Medisch Contact, 32, 1979, 1018-1020.

Post, 0. Tatrogene ziekten: een issue vanuit de algemene gezondheidszorg. 1ijdschrift voor Sociale Geneeskunde 63, 17, 1983, 740-743.

PUTrEN, P. van der, De arbeidsongeschikt verklatrde ambrenar. Een dossier onderzoek.

Scriptie in het kader van de opleiding tot social-geneeskundige, 1981.

MAKHAWY, Y., M.S. GAWAD, A.R. FAWZY \& R. SOLIMAN, The effect of personal. factors on withdrawal from work in an industrial society in Egypt. J. Egypt.med.Ass. 56, 1973, 454-460.

REE,F. Wan \& G.A.S. KOSTER van GROOS, Beknopte handleiding bij de Diagnostische Kriteria van de DSM-III.

Swets \& zeilinger B.V., Lisse, 1982.

RETCHE, H.M.J.K.I., Stress a an het werk. Swets \& zeitlinger B.V., Lisse, 1982.

RENSSEN, K., De werzorging der gebrekkigen en mismakten. Nederlands rijdscheif voor Geneeskunde, 35, 2, 1899.

RTEFF, TH. \& J.J.C.B. BREMER, Leven met ademood; inventarisatie en evaluat le var fredragswetenschappelijk onderzoek.

Nederlands Astme Fonds, Leusden, 1982.

RINGELBERG, J., Korte psychopathologie van het werk. Arts en Socital verzekering, 1973, 11,70-72.

RIS, B.G.M., Fersoneel en ziekteduur. Verslag van een onderzoek bij 39 bedrijuen.

NIPG-TNO, Leiden, 1977.

Rok, R.A., Korte geschiedenis van de personeelsselectie.

rechnische Hogeschool, 1982.

ROE, R.A., Grondslagen der personeelsselectie.

Van Gorcum, Assen, 1983 . 
ROE, R.A., Rersoonskenmerken. Handboek arbeids- en organisatiepsychologie. Van Loghum Slaterus B.V., Deventer, 1984.

ROMBOUTS, $\mathbb{R}$. Bepaling wan psychosociale stressfactoren.

Psychologie en Computers, jaargang 4, 2, NIP/Swets \&eitlinger B.V. . Amsterdam/Lisse, 1987.

ROMME, M.A.J., De betekenis van stress en de opvang daarvan door social support.

Verslag Interlimburgs Post Universitair Centrum, Mastricht/Hasselt, 1974.

ROOMANS, H.G.M., Over oordelen en vooroordelen in de diagnostiek.

In: B.G. Deelman e.a., Ontwikkelingen in de klinische psychologie. Van Loghum Slaterus B.V., Deventer, 1986, 15-25.

RUMkE, H.C., Verklaringen over het begrip psychische aiekte.

Centrale Raad van Beroep, 1951.

RUTIZENDAA, P.H., Vooroordelen in psychiatrische rapporten. Sociaal Maandblad Arbeid, 1985, 383-397.

RIJKSARBEIDSBUREAU, Classificatie van de beroepen nar hun onderlinge verwant schap.

Staatsdrukkerij en Uitgeverij, "s-Gravenhage, 1952, 2e bewerking.

SANDERS-WOUDSTRA, J.A.R. \& J. de WITTE, Kinder- en jeugdpsychiatrie.

Van Gorcum, Assen/Mastricht, 1986.

SANTEN, A.J. van, Wet op de arbeidsongeschiktheidsverzekering. Nederlandse Staatswetten.

Editie Schuurman en Jordens, Tjeenk Willink, Zwolle, 1978 , 3e druk.

SCHABRACQ, M.J., Psychologie van arbeid en gezondheid.

Tijdschrift voor Verzekeringsgeneeskunde, $26,1988,134-136$.

SCHEEF, T.J., Labeling madness.

Prentice-Hall, Englewood Cliffs, New York, 1975.

SCHELLART, A.J.M., Ziekteverzuim en arbeidsproduktiviteit bij administratieve organisaties.

Universiteit van Ansterdam, 1987.

SCHERMER, J.J., Pre-advies IT: Psychische factoren en invaliditeit. Arts en Sociale Verzekering, 8, 1970, 75-92.

SCHERMER, J.J., Revalidatie en Psyche. Arts en Sociale Verzekering, 9, 1971, 67-69.

SCHLESSELMAN, J.J., Case-control studies: design, conduct and analysis. Oxford University Press, New York, 1982.

SCHMIDT, A.J.M., Persistence behavior of chronic low back pain patients. Rijksunversiteit Limburg, Mastricht, 1986.

SCHMID, W., Psychologische Bedingungen betrieblichter Fehlzeiten Unfalle, Qual it ät smänge 1 .

Z.Arbeitswiss. $30,1976,234-239$.

SCHNTTZLER, J.G., Psychiatrie en administratief recht.

In: De psychiatrie in het Nederlandse recht. Gouda quint B.W. Aruhen, $1986,45-70$.

SCHROER, C.A.P., F.J.H. NTJHUIS \& W. van ZUTHPEN, Gebruik en betekenis van de term overspanning in geneeskundige literatur.

Tijdschrift voor Sociale Gezondheidszorg 66, 1988, 163-166.

SCHUTRMAN, J.A., Revalidatie als leerproces.

In: A. Jennekens-Schinkel, J.J. Diamant, H.F.A. Diesfeldt \& R. Haxuma (red.), Neuropsychologie in Nederland. Van Loghum Slaterus B.V., Deventer, 1980.

SELYE, H., Leven met stress.

Bussum, 1976. 
SERGEAnT, J.A., Van impliciete naar explictete psychiatrische kennis. Lezing voor de Werkgeneenschap Heslissingsgedrag. Universiteit van Ansterdan, 27 november 1987.

SHONTZ, C.F., The pychological aspects of physical illness and disability. Mackillan Publishing Co. Lnc, New York, 1975.

SINHA, A.K.P., Manifest antiety affecting industrial absenteedsm. Psychol. Reps. 13, 1963, 258.

SINHA, D., Personal factors in absenteeism. Indian J.soc.Work 17, $1956,86-93$.

SITTER, L.U. de, op weg naar nieuwe fabrieken en kancoren. Kluwer, Deventer, 1981.

SLOVIC, P., B. WISCHOE S. LICHTENSTEIN, Behavioral decision theory. Annual Review Psychology $28,1977,1-39$.

SMTT, H.G., Het neuroseverschijnsel in verband met de uitvoering van de Ziektewet.

Tijdschrift woor Sociale Geneeskunde $30,1952,371-376$.

SMITSHUTJZEM, R.Ph., Een onderzoek nat het verband tussen de DSM-TII-diagnosecode en arbeids(on)geschiktheid.

Stichting Hogere School voor Gezondheidszorg, Utrecht, 1986.

SMULDERS, P.G.W. Bedrijfskenmerken en ziekteverzuim in de jaren zestig en tachtig.

Nederlands Lnstituut voor Praeventieve Gezondheidszorg TNo, 84014, $1984 \mathrm{a}$.

SMULDERS, P.G.W., Balans van 30 jaar ziekteverzuimonderzoek: de resulcaten van 318 studies samengevat.

NT.PG-"TNO, Leiden, $1984 \mathrm{~b}$

SHITSLAAR, B. J J.M. de KLERK, Verslaving, ziekte en gebrek: op zoek naar definities.

GMD, Ansterdam, 1982.

SMTJD脃S, J.TH. Universiteit 70-80. Wolters, Groningen, 1972.

SNIJDERS, J.Th. \& F. VERHAGE, Groninger Intelligentietest (GIT). Swets \& Zeitlinger B.V., Lisse, 1983.

SOE"TERS, J. Na de ziekmelding: over de behandeling we werkhervatting van langdurig zieke werknemers.

Rijksuniversiteit Limburg, Mastricht, 1983.

SPITZ, J.C., Statist lek voor psychologen, pedagogen en sociologen. Noord-Hollandse Uit geversmat schappij, Amsterdam, 1965.

SPRUTT, J,P., Unemployment, enployment and thealth. Insticut voor Sociale Geneeskunde, Rijksuniversiteit Leiden, 1983.

SlAATSUTGEVERIJ, De geschiedenis wan de burgerlijke pensioenwelgeving in Nederland.

is $\rightarrow$ Gravenhage, 1949 .

STINLSSE, J., e.a., De Wechster Adult Intelligence Scale, 1970.

STRTEN, P.J. van, Praktijk als wetenschap: methodologie van het sociaalwetenschappel. ijk handelen.

Van Corcum, Assen, 1986.

SUESAM, N. \& M. RETCHE, Het effect wan stress. Intermediair biblhotheek, Amsterdan, 1983.

SWAAN, B. de, Oneigenlijk gebruik meemt toe onder druk van de samenlewing. Weekblad Gezondheidszorg, 7, 1981 .

IAU, E., Psychologische verschillen tussen gehandicapten na arbeidsrevalidatie.

Interfaculteit Lichamelijke opvoeding, V.U., Amsterdam, 1982. 
TALOR, P.J., Personal factors associated with sickness absence; a study of 194 men with contrasting sickness absence experience in a refinery population. Brtt.J.Industr.Med. 25, 1968, 106-118.

THISRRY, H.K., H.H.G. ZANDERS, E. KOOPMAN \& Ch.J. de MOLFE, Socital indicatoren in beweging.

Kluwer, Devencer, 1977.

TIL, M. van, En welzijn in verband met de arbeid: Literaturonderzoek. Opleiding Arbeids- en Bedrijtsgeneeskunde, Katholieke Undversiteit Ni.jmegen, 1982.

TILBURG, W. van \& H.A. GERRITSEN, Het stelsel wan soeiale zekerheid en onbegrepen lichamelijke klachten.

Boerhavecomissie voor postacadenisch onderwijs in de geneeskunde, Ri jksuniversiteit Leiden, 1985.

TIMMER, M. \& J.W. KOTEN, Verzekeringsgeneeskunde als medebeheerder van de WAO/ $\mathrm{WWW}$.

Arts en Sociale verzekering, 4, 1982, $777-784$.

TIMMER, M. \& J.W. KOTEN, Over kwaliteitseisen en de kwaliteitsbewaring Len aanzien van de verzekeringsgeneeskunde.

Tijdschrift voor Sociale Gezondheidszorg 62, 1984, 259-276.

TIMMER, M. Verzekeringsgeneeskundig referentiekader (deel UI): Stoornissen in verzekeringsgeneeskundige zin.

Tijdschrift voor Verzekeringsgeneeskunde, jaargang $23,1985 a, 40-42$.

TIMMER, M., verzekeringsgeneeskundig referentiekader (deel III): over het getotal iseerde arbeidsvermogen.

Tijdschrift voor Verzekeringsgeneeskunde, jaargang 23, 19850, 76-80.

TIMMER, M. , Verzekeringsgeneeskundig meferentiekader (deel IV): over werkuitwoeringseisen.

Tijdschrift voor Verzekeringsgeneeskunde, jaargang 23 , 1985c, 106-109.

TIMMER, M., De verzekeringsgeneeskundige functie van een tiental uitvoeringsorganen in de sociale verzekeringssfeer.

Tijdschritt voor Verzekeringsgeneeskunde, jaargang 26, 1, 1988, 6-13.

TISSING, M.O., Een evaluatie-onderzoek van de door de Gemeenschappelijke Medische Dienst in de jaren 1981 tot en met 1984 bij de Arbeids Revalidatie Afdeling (ARA) te Zaandam ingebrachte personen.

Stichting Sociale Gezondheidszorg, Utrecht, 1987.

TOTMAN, R. , De ziekmakende factor.

Garma Publicaties, 1981.

VANMEULENBROECK, H.M.W., De ontwikkeling van het begrip 'ziekte" en het begrip 'arbeidsongeschiktheid" in verband net de sociale wetgeving. In: F" Doelman (red.), Verslag van the Boerhave-cursus over arbeidsongeschiktheid, ziekte en sociale verzekering. Faculteit der Geneskunde, Rijkstuiversiteit Leiden, 1982,41-57.

VELDKAMP, G.M.J., De crisis in de Nederlandse sociale zekerheid anno 1976. Uitgeversmat schappij Bonaventura, Amsterdam, 1976.

VERHULST, J., Pokerspel geneeskunde.

Nederlandse Uitgeverij, Antwerpen/utrecht, 1974.

WERHULST, J.C.R., Algemene psychologie van de gezondheidszorg.

Wolcers Noordhoff, Groningen, 1985.

VERKLEY, H.\& J.P. SPRUTT, Trends in her aantal ziektewetuitikeringen an werkelozen en werkenden 1975-1982.

Tijdschrift voor Sociale Gezondheidszorg, 63, 16, 1983, 712-717.

VISCARDJ, H., "Can disabled workers meet the demands of automation?"

Advanced Management, volume 22, 7, 1957. 
VISSER, R.S.H., J.C.VLIET-MULDER, A. EVERS \& J. ter LAAK, Docuntentate van cests en testresearch in kederland.

NIP, Amsterdan, 1982.

VLEK, C.A.J., Psychologische besliskunde. De Psycholoog XX1. $1987,73-86$.

vos, B., Evaluatie van een nieuwe samenwerkingsvorm tussen de behandelende sector en de GMD.

Stichting woor Sociale Gezondheidszorg, Utrecht, 1976.

VREEDE, H.M.J. de, Inleiding tot de beroepenkunde. GM, Stafifdeling opleidingen, Amsterdam, 1977.

VROEGE, $\mathbb{D}$., Verkenningen rond het concept belasting-belastbaarheid. Tijdschrift voor Sociale Geneeskunde $60,24,1982,793-798$.

VROLIJK, A. . Stressmanagement.

In: Hederlandse Vereniging voor Bedrijfspsychologie 77 , Omgan met stress in de organisatie. Kluwer, Deventer, 1984.

VROOLAND, V.Chr., Werk en gezondheid: over ziekteverzuim en humanisering van de arbeid.

Alphen aar de Rijn, 1982 .

VROOM, W.H., REgo-involvement, job satisfaction and job performance. Personel Psychol. 15, 1962, $\| 59-177$.

VROOM-KASTELEIN, W.R., Inzage: ja of nee? Medisch Contacto, $40,987$.

VUCHT TIJSSEN, J. van, A.A.J. van den BROECKE, N. van DTJKHUIZEN, H.M.J.K.I. REICHE \& Ch.J. de WOLFE, Middenkader en stress. COP/SER, $-\$-G$ Tavenhage, 1978.

WEHMAN, A., Een evaluatie-onderzoek betreffende psychologische expertises. Stichting Hogere School voor Gezondhejdszorg, Vtrecht, 1985.

WELEY, P.A. van, Onderbelasting in het werk. Nederlands Tijdschrift voor Geneeskunde, 125, 1981, 1659-1661.

WELLEM, J.G.M., Medicalisering van de samenleving. Metamedica, $60,1981,197-209$.

WESTMEYER, H., Grundlagenprobleme psychologischer diagnost ik. In: K. Pawlik, Diagnose der diagnastik. Klett, Stuttgart, 1976, 71-101. WEYEL, J.A., Neurose en neurotische verschijnselen in het arbeidsleven. In: A. Nap (red.), Validiteitsonderzoek. Stafleu, Leiden, 1970, $25-43$.

WEYEL, J.A., De invloed van sociale zekerheid un een maatschappij van overyloed op ziektegedrag.

Arts en Sociale Verzekering, 1974, 17-23.

WEZEL, J.A.M. wan, Ferintreding in hec arbeidsproces, een onderzoek onder werklozen.

Katholieke Hogeschool, Tilburg, 1972.

WIEGERSMA, S. \& P.J. wan BOCHOVE, De wereld der beroepen. De Toorts, 1976.

WIELEN, $Y . v, d$. , Begelleiding van verzekerden in de gezondheidszorg van morgen.

Arts en Sociale Verzekering 16, 1978, 24-27.

WIERSMA, D., Psychosociale stress en langdurige arbeidsongeschiktheid. Groningen, 1979.

WIERSMA, D., Langdurige arbeidsongeschiktheid: ongelijkheid in gezondheid of in social-economische omstandigheden.

Tijdschrift voor Sociale Geneeskunde 58, 1980.

WIERSMA, D. "H.W. HOEK, \&M. RUPHAN, Psychologische stoornissen en sociale beperkingen.

Tijdschrift voor Verzekeringsgeneeskunde, jaargang $24,1986,109-\| 12$. 
WLGGINS, J.S., Personality and prediction. Addison-wesley Publ. Comp. Massachusetcs, 1973.

WLDE, G.J.S. de, De Amsterdamse Biografische Vragenijat, 1970.

WINKLER PRINS, V., De maatschappelijke betekenis van geneeskundige keuringen.

Tijdschrift voot Sociale Geneeskunde, 1961, 75-80.

WINNUBST, J.A.M., Stress in organisaties: naar een nieuwe benadering van werk en gezondheid.

In: P.J.D. Drenth e.a., Handboek arbeids- en organisatiepsychologie.

Van Loghum Slaterus B.V., Deventer, 1984.

WINTER, E.R. de, Verzuim, Litspraken van werknemers en latere arbeidsongeschiktheid.

NTPG-TNO, Leiden, 1983.

WOLFF, CH.J, de, Werk en belasting.

Nederlands Tijdschrift voor Geneeskunde, $125,1981,1661-1664$.

WOLFE, H.G. \& H. GOODELL, Stress and disease.

C.C. Thomas, Springfield Mlinois, 1968.

WOLPE, J., Psychotherapy by reciprocal inhibition. Stanford University Press, California, 1958.

wood, P.H.N., The language of disablement: a glossery relating to disease and its consequenses.

International Rehabilitation Medicines, wol . 2, 2, 1980, 86-92.

WORLD HEALTH ORGANIZATTON, International classification of impajrments, disabilities and handicaps.

Genève, 1980.

WORTMAN, J.L.C., Het ziekenhuis voorheen en thans.

Nederlands Tijdschrift voor Geneeskunde, jaargang 59, 1915, 1313-1315.

WOUTERS, P.H.M., Handboek I.C.D. 9. GMD, Arusterdam, 1984 .

WRTGHT, B.A., Physical Disability, a psychological approach. Harper, New York, 1960.

WIJNBERG, B. \&W. JOLING, Ongelijkheid in gezondheid. Medisch Contact, 28, 1987, 871-875.

WIINEN, M.C., Ziekteverzum bij hoveniers, werkzam bij de Dienst Sociale We rkvoorziening te Zaandan.

Stichting voor sociale Gezondheidszorg te Utrecht, 1986.

ZAAL, M.J., Notities inzake arbeidsongeschiktheid.

ijdschrift voor Psychiatrie, 1974, 183-189.

ZANDERS, H.L.G. "Sociale indicatoren: meetinstrumencen voar de matschappij.

In: M.R. van Gils (red.), Werken en miet werken in een veranderde samenlewing. Swets \& Zeitlinger B.W. Amsterdam, 1975, B2-92.

ZANDWOORT, J.M.E. van, Psychiatrische oordeelsvorming in rapporten. Medisch Contact, 19, 1987, 599-604.

ZEEUW, J. de, Algemene Psychodiagnost lek I. Swets \& Zeit inger B.V., Lisse, 1981.

ZUNG, W.W.K. \& Mc.DURHAM, A selfrating depression scale. Arch. Gen. Psychiatry, 12, 1965, 63-70.

zUThEM, H.J. van, Technologische revolutie kan leiden tot kaste van pariáa $s$.

Noord-Hollands Dagblad, 26 september 1987.

ZUUREN, F.J. van, Kwal it at ief onderzoek.

De Psycholoog, 6, 1987, 283-289. 
2WEEKHORST, W.A., Passende arbejd: knelpunt van de arbeidsongeschiktheidsverzektering.

Social Maandblad Arbeid, 32e jaargang, 12, 1977, 253-255. 


\section{BI I.AGEN}

A Aantal uitkeringsgerechtigden op 31 december nat diagnose van 1981 tot en met 1985 (GMD Jaarverslag 1985)

B Het aantal blijvend ongeschiktverklaveden bij het ABP in de periode 198 -1985, verdeeld natr ziektecategorie (ABP Jarverslag 1985)

C Beschrijuing van de psychologische persoonskennerken

D. Lijst van afkortingen 
BLJLAE A

Aantall uitkeringggerechtigden op 31 december naar diagnose van 1981 tot en met 1985 (CHD Jaarvers lag 1985)

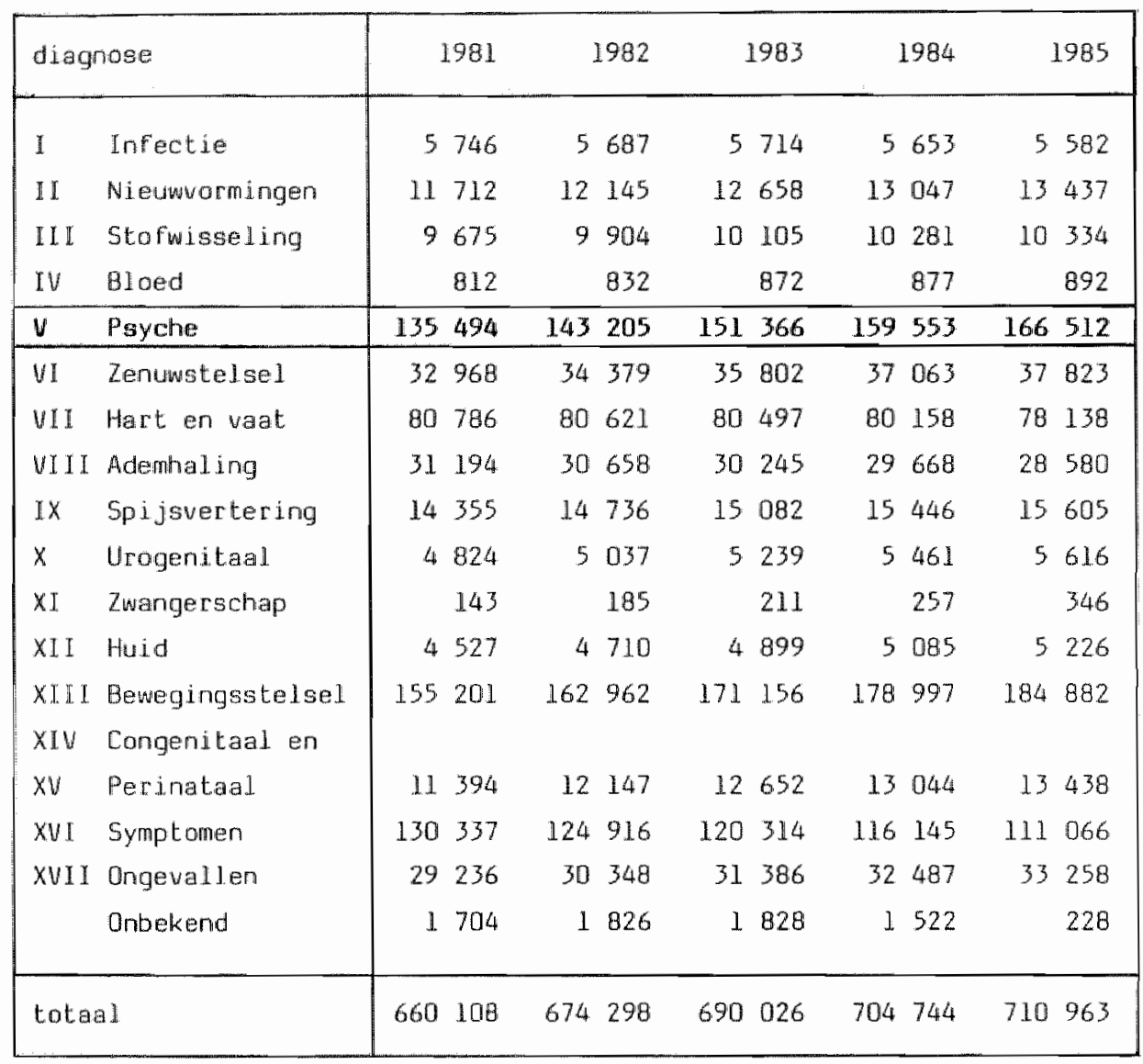


Het aantal blijuend arbeidsongeschikt verklaarden bij het ABP in de periofe 1981-1985, vedee1d naar ziektecategorie (ABP Jaarverslag 1985)

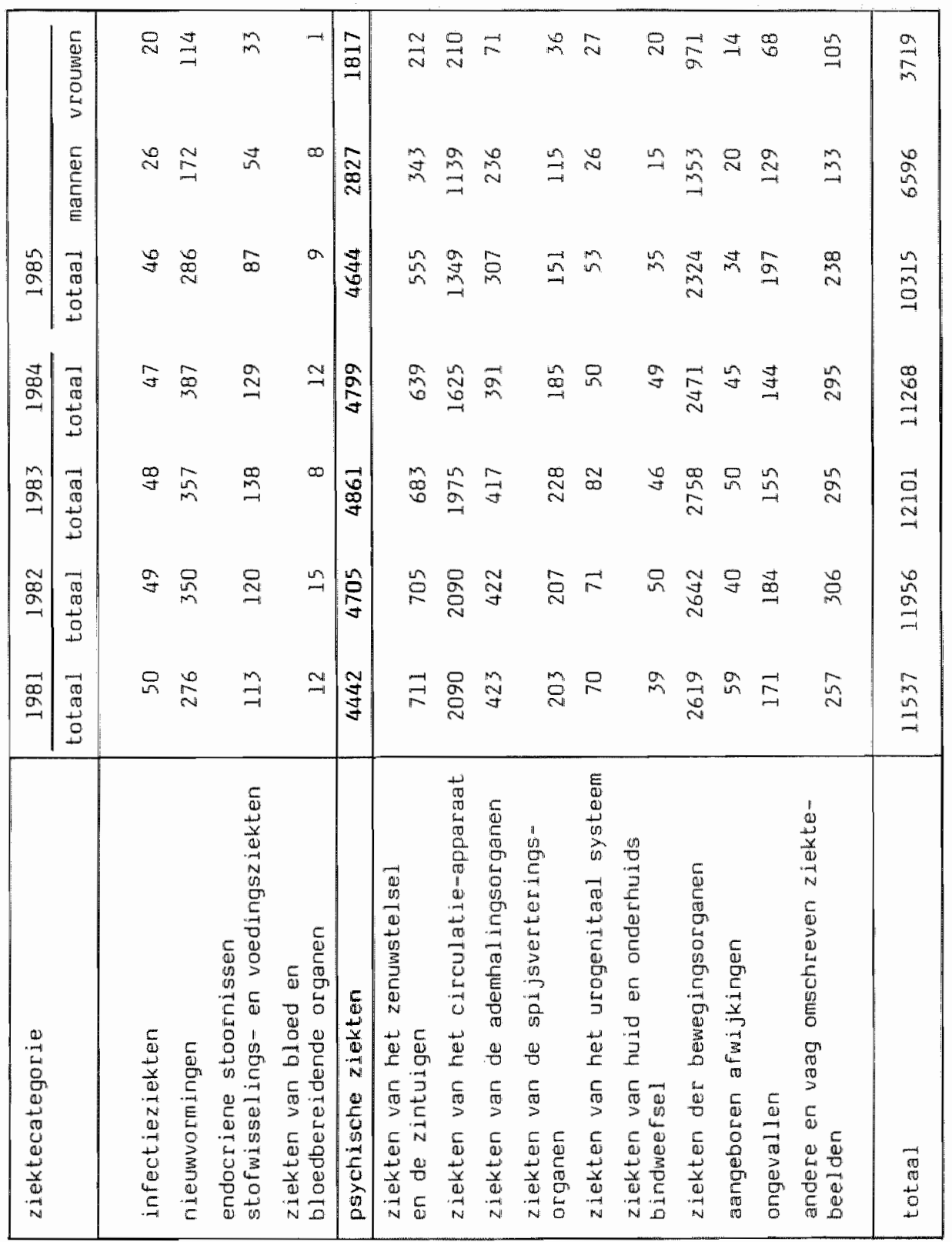




\section{MUAGE C}

Beachrijuing van de psychologische persoonskenmerken

Hiervolgend mordt per onderzoeksinstrument dat in deze studie is gebruikt angegeven op welke psychologische persoonskenmerken dit betrekking heeft en wat de meest relevante betekenissen en interpretaties wan bepaalde seores zijn.

\section{De Wechster Hdult Intelligence Scale (WAIS)}

Deze test bestat uit twee gededten, het zogenamde mondelinge of werbale gedeelke en thet zogenaande handelings- of performantiegedeelte.

Het mondelinge deel bestaat uit zes subtests (WAIS 1 tot en met 6), terwijl het hardelingsgedeelte uit vijf subtests bestar (WAIS 7 cot en met $11)$.

Hieronder volgt een karte beschrijving van de verschiliende subtests.

Vook uitgebreidere informatie wordt verwezen naar Stinissen e.a. (1970), De zeeuw (1980) en Visser e.a. (1982).

\section{Informatie (HAIS I)}

Deze subtest bestat uit een aantal vragen die betrekking hebben op de algemene ontwikkeling en kennis vanuit het dagelijks leven. De resultaten zijn een indicatie voor de breedce van de algemene kemis en van de belangstelling voor en de cognitieve oriencatie in de realiteit.

\section{Hegrijpen (WAS 2)}

Deze subtest heeft betrekking op het begrip voor allerlei praktische levenssituaties (begripsvermogen). De antworden geven informatie over inzicht van de onderzochte in allerlei praktische situaties ea her vermogen on gedachten of opvattingen op adequace wijze onder woorden te blengen.

Rekenen (WAIS 3)

Deze subtest heeft betrekking op het rekeninzicht en doet een beroep op het. "korte-termijngeheugen".

overeenkomsten (WAIS 4 )

Deze subtest betreft het miveau van het abstractievermogen. Het is een cest voor abstactie- en concept formatie en appelleert wat dat betreft aan het vernogen tot abstraheren en generaliseren door middel van taal.

cijferreksen (WAS 5 )

Deze opgave geeft het vermogen weer on korcdurend cijfers in te prenten, vast te houden en te reproduceren. Deze memorisatie- of inprentingstest wijat, nast het goed om kumen gan met cijfers, op het concentratievermogen en het korce-termijngeheugen.

Woordenschat (WALS 6 )

Deze testopgave geeft een beeld van de woodenkennis (synoniemen, essentielle eigenschappen, causale relaties en acties) en geeft aanwijzingen over het vermogen tot het werbaliseren van ideeen en gedachten door middel van de verworven woordenschat. 


\section{Substitutie (WAIS 7)}

Deze subtest heeft enerzijds betrekking op de oog-handcobrdinatie an anderzijds op het psychomotorische en perceptuele tempo.

\section{Onvolledige tekeningen (WAIS 8)}

Deze subtest betreft het vermogen tot het kitisch warthemen wan wisueel gepresenteerde objecten (patroonimprenting).

\section{Blokpatronen (WAIS 9)}

Deze subtest betreft het ruimtelijk inzicht op het platte vlak als cen analytüsche ruimelijk-perceptuele component van het praktisch-handelend denken.

Plat jes rangschikken (WAIS 10)

Deze subtest geeft het inzicht in sociale situaties, het realiteitsbesef en het begripsvermogen, zonder dat dit overigens iets zegt over de sociale aangepastheid.

\section{Figuurleggen (WAIS I1)}

Deze subtest doet een beroep op de zogenaande wisuele conceptformatie, warbij het gat over de anticiperende perceptuele en motorische coordinatie.

\section{De Differentiële Aanleg Test (DAT)}

\section{Werktempo en nauweurigheid}

Met deze test wordt een indruk verkregen van het werktempo en de naukeurigheid bij eenwoudige handelingen van routinematige aard, beide belangrijke vereisten in vele werksituaties.

Zie voor een uitgebreide en gedifferentieerde beschrijwing van de bifferentiële Aanleg Test: Fokkema en Dirkzwager (1968), De Zeeuw (1980) en visser e.a. (1982).

\section{De Minnesota Multiphasic Personality Inventory (MMPI)}

De MMP telt 13 schalen ter bepaling wan specifieke psychologische en psychopathologische persoonskenmerken.

Hiernavolgend wordt iedere schaal beschreven in de volgorde, wartin ze op het MMPI-profiel woorkomen.

Voor een uitgebreide interpretatie ervan wordt verwezen mar Nuttin en Beuten (1969), Lachar (1973), Dahlstrom e.a. (1975) en Greene (1980).

\section{Leugenschaal (t-schaal)}

De zogenaande $\mathrm{L}-$ schal beoogt aan te geven in hoeverre i.emand zich extra gunstig heeft willen voordoen, dat wil zeggen meer gereageerd heeft op geleide van sociale wenselijkheid dan vanuit reële zelfrapportage.

Hoge scares kunnen wijzen op:

- een algemene instelling om een goede indruk te willen maken en fouten ew/or gebreken te ontkennen;

- nauwgezetheid, als zijnde een bijzondere trek in de persoonlijkheid;

- overmatige conventionaliteit, rigiditeit en zelfoverschatting; 
- een neurotische katakterontwikkeling, o.a. tot witing komend in het hanteren wan neurotische arwermechanismen;

- een gebrek aan zel finzicht en een geneigdheid cot sonatiseren;

- psychische onrijpheid.

\section{Frequent ieschaal (F-schaal)}

De rogena ande $\mathrm{F}$-schaal heert betrekking op stoornissen in gedachten, overtuigingen en levenshouding. Daarnaast heeft deze schaal betrekking op een apathische houding, gebrek aan interesse en ontkennen van sociale verantwoordelijkheden en verplichtingen.

Hoge scoreg kunnen wijzen op:

- ernstige psychiatrische stoornissen (desorganisatie binnen de persoon, zich o.a. mogelijk uitend in psychotische reacties);

- ernstige stressstoornissen;

- identiteitscrisis;

- enotionele labiliteit, samenhangend met een theatrale levenshouding.

\section{Correctieschaal $(K-\operatorname{schaal})$}

De correctieschaal, de zogenaande $k$-schaal, is bedoeld als een correctiefactor on de discrininatiewaarde van de hiervolgend beschreven klinische schalen te verhogen. De $K-s c h a d$ meet de mate van defensieve instelling (atcicude) van betrokkene ten opzichte van de vragenlijst.

Hoge scores wijzen op:

- een verdedigingshouding aangaande de eigen psychische zwakte:

- rigiditeit en een gebrek aan flexibiliteit, beperkingen gevend in het int rospectieve vermogen en het begripsvermogen;

- zich "normaler" willen woordoen dam men zich in werkelijkheid voelt.

\section{Schaal 1: Hypochondrieschaal (Hs-schaal)}

De Hs-schaal is bedoeld on een overmatige bezorgdheid aangande de lichamelijke functies aan te geven.

Hoge uitslagen wijzen op:

- overdreven ongerustheid over de gezondheidstoestand;

- een geneigdheid tot klagen over allerlei pijnen en ongesteldheden, die somat isch moeilijk te identificeren zijn;

- de uiting van psychische en emotionele conflicten in de vorm van somatoforme klachten, warbiji er sprake is van een preoccupatie met de somatiek;

- een pessimistische, klagerige, passief-agressieve instelling ten opzichte van de omgeving;

- egocentriciteit en psychische on ijpheid, warmee de problemen van leven als volwassene worden benaderd;

- een gebrek aan inzichr in de emotionele basis van de Iichamelijke klachten;

- een geneigdheid door middel van overdreven lichamelijke klachten te zoeken nar sympathie en erkenning bij zowel de directe omgeving alls behandelaars, tewijl er vanuit een zeker wantrouwen een geneigdheid is om zich ten anzien van medische en/of psychotherapeutische behandeling negatiet op te stellen.

\section{Schaal 2: Depressieschaal (D-schaal)}

De D-schal geeft de mate van depressiviteit weer, hetzij als klinisch hootdsymptoon van psychische ontreddering, hetzij als nevenverschijnsel. van andere psychische stoornissen. 
Een hoge uitslag kan wijeen op:

- een gevoel van onbekwaameid, pessimisme, een laag moreel en gevoelens van nut to loosheid en hopeloosheid;

- een gebrek aan interesse, apathie, onbekwamheid om te werken en fysieke klachten;

- een neiging tot onrustig piekeren, beperktheid van interesse, introversie en vooral een gebrek aan zelfvertrouwen.

Schaal 3: Hysterieschaal (Hy-schaal)

De Hy-schaal signaleert de tendenten tot algemeen functionele of meer specifieke conversiestoornissen als middel on conflicten op te lossen dan wel (onberust) verantwoordelijkheden te vermijden.

Een hoge score kan wijzen op:

- een verhoogde kans op conversie- en/of somatoforme stoon issen (onder stress);

- algehele psychische onrijpheid;

- ontkenning van sociale angst;

- behoefte aan affectie:

- vermoeidheid, matheid, algehele malaise;

- gerende agressie;

- gedrag dat naar buicen coe vriendelijk, enthousiast en ontvankelijk is, maar tegelijkertijd ook egocentrisch en be Invlloedbara;

- onijp, manipulatief, eisend en kunstmatig gedrag;

- een defensieve en rigide instelling.

\section{Sichaal 4: Psychopathische deviatieschaal (Pd-sichaal)}

De Pd-schaal beoogt de bepaling van de mate wan geneigdheid tot anti-sociaal gedrag.

Hoge scores kunnen wijzen op:

- een onvermogen om met gevoelens om te gaan van zowel zichzelf als van anderen;

- een onvermogen om gevoelens op een juiste wijze te uiten;

- een geneigdheid tot impulsiviteit;

- non-conformisme en een sterke geneigdheid tot anti-sociale agressieve gedragsdoorbraken;

- het niet vatbaar zijn voor diepe, affectieve reacties;

- het onbekwaam zijn om gebruik te maken van apgedane ervaringen, het: negeren van sociale gedragsvormen en gebruiken;

- een onvermogen on te anticiperen op consequenties van het eigen gedrag en/of van ervaringen te leren (inclusief straf en psychotherapie);

- het gemakkelijk aangan wan interpersoonlijke relaties, met een gebrek aan reele intimiteit;

- autoriteitsproblemen;

- een geneigdheid tot ant $i$-social gedrag.

\section{Schaal 5: Activiteit-passiviteitschaal (Mf-schaal)}

De Mr-schal gat na in welke mate iemand een actieve en assertigve inste1ling heeft dan wel op grond van gevoelens van machtelooshejd, afhankelijkheid en zelfmedelijden tot passiviteit geneigd is. 
Moge scokes wizen bij vroumen op:

- een act icve instelling;

- zellatindigheid:

- dominameie:

- stridvardigheid;

- agsertibutét

- agressiwiteic.
Hoge scores wijzen bij mannen op:

- een passieve instelling;

- omgevingsafhankel ijkheid;

- (sociale) overgevoeligheid;

- innerlijke gerichtheid (zelfmedelijen);

- bezorgaheid;

- machte loosheid.

\section{Schaal 6: Paranoiaschaal (Pa-schaal)}

De Pawsctal is bedoeld om paranotde symptomen, zoals extreem wantronwen, overgevoeligheid, vervolgingswaan, all of niet gepaard gaand met grootheidswaan en paranoìde persoonskermerken, te meten.

Hoge scores kunnen wijzen op:

- zeer snel Lichtgeraakt zijn;

- star kunnen reageren in interpersoonlijke verhoudingen, voortwloeiend uit want rouwen:

- gefixeerd $2 \mathrm{ijn}$ in een bepalde avertuiging (rigiditeit).

\section{Scharal 7: Psychasthenieschaal (Pt-schaal)}

De Pt-schal heeft betrekking op de mate van obsessieve, compulsieve neurotische, dan wel angstroornissen, zoals dwangmatig denken en handelen. Verder meet de schad onredelijke (fobische) vreesreacties ten opzichte van voorwerpen en situaties en irreële angstreacties. In algemene zin wordt onder psychasthenie een verhoogde psychische kwecsbaarheid door gebrek aan psychische spankracht verstaan (Janet, 1903).

Hoge scates wijzen op:

- angst;

- gebtek aan zel fvertrouwen en zelfwardering;

- overmatige overgevoeligheid;

- stemminguisselingen in de vorm van lichte depressiviteit, overdreven ongerustheid, tobben;

- neurotische tendenties, zoals schuldgevoel, zich zorgen maken, angst, twijfelen aan zichzelf;

- een ineffectief gebruik van afweermechanismen, zoals intellectuliseren, rationaliseren en isoleren, ofwel het onvermogen om angst en spanning te reduceren;

- snel optredende daling van de psychische spankracht bij overbelasting.

\section{Scharl 8: Schizofrenieschaal (Sc-schaal)}

Deze achaal. beoogt de mate te meten warin er sprake is van een warverhouding cusaen de realiteit en de subjectieve belewing en warnening ervan. Omstanders kunnen de gedragingen en de gemoedstoestanden wegens de oninvoelbaarheid, bizarheid en ongewoonheid ervan dikwijls niet volgen.

Hoge scores kunnen wijzen op:

- een schizolde geestesgesteldheid;

- gevoelens van ontkenning en anders zijn;

- gevoelens wan nite begrepen worden, waardoor men zich isoleert en inferieur voelt:

- moeilijkheden hebben met het uiten van gevoelens van vijandigheid;

- een neiging tot cerugtrekken;

- moeilijkheden in de communicatie en de mate warin iemand zichzelf verliest in allerlei fantasieen. 
Schaal 9: Hypomaneschalal (Ma-schaal)

De Ma-schal beoogt de tendens tot hypomanie vast te stellea, dat wil zeggen de mate van euforie en hyperactiviteit in denken en doen aar te geven.

Hoge scores wijzen op:

- overactiviteit in denken en doen en daarbij het risico hopen in moeilijkheden te geraken, omdat er teveel zaken ineens worden ondernomen:

- een verhoogde kans op moeilijkheden met anderen wegens een geneigdheid on sociale gebruiken af te keuren ofwell te hervormen; de algehele overactiviteit wordt gekenmerkt door een instabiele steming en vlucht in idealen, hetgeen kan worden afgewisseld met depressiviteit, eufore stemming, toegenomen prikkelbaarheid en improdukt iviteit;

- hyperactiviteit, geaguteerdheid en manische opgewondenheid, wasbij de 'aard' der hyperactiviteit en opgewondenheid bepalt of er sprake is van pathologie;

- een slechte impulscontrole, kunstmatig verhoogde afleidbartheid en een nare istische instelling.

\section{Schaal 0: Sociale introversieschaal (Si-schaal)}

De si-schal betreft de tendens van het vermijden van social contact, het zich onplezierig voelen in sociale interactie en mogelijk het antbreken van sociale vaardigheder.

Hoge scores wijzen op:

- inferioriteitsgevoelens;

- zich niet willen aanslujten bij anderen;

- een lage behoefte aan sociale contacten;

- overgevoeligheid voor meningen en kritiek van anderen;

- interpersoonlijk wantrouwen;

- geneigdheid tot somatiseren met onvermogen tot sociale aanpassing, c. ter overdekking van verlegenheid en gebrek aan zelfvertrouwen;

- een schizolde acceptat ie, neurotische zelfdeprivatie en depressiviteit.

\section{De Amsterdamse Biografische Vragenlijst (ABV)}

\section{Psychoneurotische en functionele (lichamelijke) klachten}

onathankelijk van de fysisch-diagnostisch vaststelbare functiebeperkingen kan de psychische belastbarheid worden afgeleid uit de mate watin er sprake is van psychoneurotische en/of functionele (lichamelijke) klachten. Hoge scores kunen wijzen op 'neurotisch energieverlies', waardoor de psychische spankracht onvoldoende kan zijn of worden om de psychische belasting, war men mee wordt geconfronteerd, an te kunnen. Dit kan zowel een gevolg zijn van een te grote draghlast als een te geringe, dan wel afgenomen draagkracht.

\section{Extraversie}

Deze schal geeft a an hoe iemand zijn gevoelens ervart en hanteert in zijn dagelijks bestaan. Dit hangt direct samen met het vermogen tot het leggen en onderhouden van sociale contacten.

Hoge scores wijzen op een extraverte instelling.

\section{Defensiviteit ten aanzíen van gevoelens}

Deze schaal geeft de mate aan warin iemand verdringingstendenzen heeft ten aamien van zijn gevoelens.

Hoge scores geven de mate van defensiviteit aan, hetgeen betrekking heert 
op de lans dat iemand psychische problemen verdrangt, gevoelens afweert, kritiek vertijd en weinig openhartig is (Wilde, 1970 ).

\section{De Zelf-Beoordelings Vragenlijet (2BV)}

\section{Angst}

In dit onderzoek word gebruik gemakt van een Nederlandse bewerking van de State-Trait-Anxiety-Inwentory van Spielberger e.a. (1973), in de vorm van de zell- Beoordelings Vragenlijst (ZBV: Van der Ploeg e.a., 1980).

Met behulp wan deze vagenlijst kunnen twee afzonderlijke vormen van angst worden gemeten, te weten toestandsangst en angstdispositie.

Toestandsangst is een situationeel bepalde voorbijgande enotionele conditie van het individu. Kenmerkend zijn de subjectief ervaren gevoelens van spanning of gespannenheid, een werhoogde activiteit van thet autonome zenuwstelsel en de darmee gepard gande psycho-fysiologische reacties.

Een hoge score op deze schaal betekent dat iemand situaties, inclusief de onderzoekssicuatie, als een bedreiging ervaar.

Angstdispositie verwijst naar algemene geneigdhejd on te reageren met een verhoging in de intensiteit van de coestandsangst op als bedreigend ervaren situaties.

Een hoge score op deze schaal betekent dat iemand in het algemeen in bedreigende sicuaties reageert met een verhoging in de intensiteit wan de toestandsangst.

Bepaling wan het niveau van beide vormen van angstgeneigdheid is erop gerich on inzicht ce krijgen in enerzijds de mate warin iemand zich in nieume, onbekende situaties snel angstig en gespannen voelt en anderzijds in het algemene karakcerologische angstriveau.

De meest vaortkomende arbeidsbelemerende angststoornissen zijn volgens Suesan en Reiche (1983):

- doodsangst (biologische oerangst);

- angst voor Iichamelijk letsel, verwonding, fysische schade en pijn;

- verlies-, verlatings- en scheidingsangst;

- gewetens-, beschuldigings- en afwijzingsangst;

- scharmo en fallangst.;

- angst voor het onbekende.

Deze vormen van angst kunnen gepaard gaan met motorische spaningsverschijnselen, somatoforme klachten als gevolg wan hyperactiviteit van het autonome zenuwtelsel, angstige verwachtingen, vermijdings- en agressief gedrag, waardoor mensen beperkt worden in hun arbeidsvermogen en beroepsvaardigheden en daardoor tijdelijk of blijvend arbeidsongeschikt kumen s.i.jn.

Bij langdurige arbeidsongeschiktheid op grond van angststoornissen is er volgens Hoencamp en Rijnhart (1988) nogel eens sprake van een anti-therapeutische instelling bij betrokkenen wit "angst voor de angst" en is de prognose op herstel van de arbeidsgeschiktheid mede op grond darvan ongunstig. 


\section{Depressie}

Ter bepaling wan de subjectief ervaren depressiviteit wordt in dit onderzoek gebruik gemakt van de Zelfbeoordelingsschatl voor depressie (zung, 1.963).

De items tit deze vragenlijst hebben betrekking op symptomen van depressie, onderscheiden naar:

- verstaring van de gemoedsrust, die zich kennerkt door overheersende gevoelens van verdriet en me tancholie;

- verstoring van fysiologische processen, zoals die tot uiting komen in dagschomme ingen, verminderde eetlust, problemen met de stofwisseling en vermoe idheid;

- psychomotorische stoornissen in de vorm van hetrij agitatie, hetzij geremdheid;

- psychologische stoornissen, zoals verwardheid, leegheld, besluiteloosw heid, een lage zelfwardering en sulfidegedachten.

Een hoge score duidt op een verhoogde mate van depressiviteit.

In algemene zin is depressiviteit geen reden voor een blijvende arbeidsongeschiktheid, hoewel met name depressies op oudere leeftijd dartoe wel. aarleiding kunnen geven wegens hun verhoogde kans op een chronisch karakter van deze stemingstoornis.

ook al is er bij minder ernstige depressieve gevoelens in de vorm van dysthyne stoornissen op voorhand geen sprake van arbeidsongeschiktheid, roch is er bij dergelijke stoornissen ter objectivering van het subjectieve beleven van 'niet kunnen werken' volgens Foencamp (1987) een indicatie voor psychologisch testonderzoek naar resterende psychische belastbarheid en be roepsvaardigheden .

Bij chronische pijnpatiënten treden waak depressies op (Fordyce, 1976). De betrokkene wordt depressief door het obsessionele idee dat bepalde activiteiten niet of nauwelijks mogelijk zijn geworden. De depressie is bij deze mensen niet altijd even duidelijk waannembaar (Sternbach, 1978), o. a. wegens maskering ervan door somatische preoccupatie - de overbezorgdheid voor het eigen lichaam.

Wat betreft de relat ie tussen depressiviteit en arbeidsongeschiktheid kan worden gewezen op de bevindingen van Mc.Daniel (1969), die heeft gecon stateerd dat mensen die depressief zijn hun kansen om een bepald doel te bereiken - zoals hec vinden van a angepast werk - lager inschatcen dan zij die minder depressief zijn.

De Vragenlijst voor Onderzoek van de Erwaren Gezondheidstoestand (VoLG)

\section{Ervaren gezondheidstoest and}

De VOEG betreft subjectief ervaren gezondheidstoestand en geeft het resultaat aan van de interactie tussen de lichanelijke en psychische draagkracht van het individu in relatie tot de omstandigheden waronder hij op dat moment leeft.

In tegenstelling tot de neurotische somatiseringsfactor van de $A B V$ vormt "ervaren gezondheid" geen persoonskenmerk, maar een situationeel gebonden reactiepatroon, waarin bij wisseling van onstandigheden veranderingen zijn te bewerkstelligen, voor zover persoonlijkheidskemerken dit ook toelaten. Hoge scores kunnen wijzen op intrapsychische spanningen als gevolg van hec 
zich (bewuse en onbewust bedreigd of overbelast voelen. De scores kunnen worden opgevat als etr mate van algemeen onwelbevinden en derhalve als een indrecte indicator voor de belastabarheid.

Wolgens Weyel (1970) kan een hoge score op de VokG wijzen op een 'hyperesthet isch-emotionee 1 syndroom", hetgeen betrekking heeft op somatoforme Klachten op basis van angststoornissen, depressieve (dysthyme) stoornissen, aanpassingstoornissen en 'overspannenheid'.

\section{De Dijnschaal (PS)}

\section{Pijnbeleving}

Naar analogie van de angsthermometer van Wolpe (1958), gegradeerd in zogenaande 'subjective units of disturbance' (SUD), is door Fordyce een pijnthermometer geconstrueerd. Als operationalisering van de variabele pijn in dit onderzoek wordt van deze pijnthermometer gebruik gemakkt, dit mede wegens de eenvoud in het gebruik en de betrouwbarheid ervan.

op een schaallijn van 0 rot $10 \mathrm{~cm}$ moet iemand aangeven hoe ernstig de ervaren pijn is.

De hoogste score (10) betekent dat ienand de pijn als ondraghlijk ervaart.

Wanner voor de (pijn-)klachten van betrokkene geen lichamelijke en/of psychische 'ziekte of gebrek' als oorzakelijke verklaring kan worden gevonden, wordt betrokkene, ondanks zijn klachten, niet als arbeidsongeschikt in de zin der wet beschouwd (Centrale Raad van Beroep, 21 december 1979 en 17 december 1982 .

Derhalve is een verklaring voor de subjectieve pijnbeleving in termen van stoornissen op respectievelijk sensorisch-tysiologisch, motivationeel-emotioneel, cognitief en gedragsniveau een noodzakelijke voorwarde on over arbeidsongeschiktheid te kunnen spreken. Het verdient aambeveling deze stoornissen te 'transponeren' nat het classificatiesysteem van de DSM-III-R (APA, 1987), zodat een diagnose kan worden geformuleerd en deze 'bevestigt' dat er sprake is van een ziekte of gebrek (lancée, in press). 


\section{BIJLAGE D}

\section{Lijst van afkortingen}

\begin{tabular}{|c|c|}
\hline AAW & Algemene Arbeidsongeschiktheidswet \\
\hline $\mathrm{ABP}$ & Algemeen Burger1ijk Persioenfonds \\
\hline$A B V$ & Amsterdamse Biografische Vragenlijst \\
\hline $\mathrm{AG}+$ & arbeidsgeschikt \\
\hline $\mathrm{AG}^{-\infty}$ & arbeidsongeschikt \\
\hline $\mathrm{AMP}$ & Algemene Militaire Pensioenwet \\
\hline $\mathrm{BG}+$ & in beroep gegaan \\
\hline BG- & niet in beroep gegaan \\
\hline $\mathrm{BV}$ & Bedrijfsverenging \\
\hline CBS & Centraal Bureau voor de Statistiek \\
\hline DAT & Difterentiele Aanleg Test \\
\hline DSM & Diagnostic and Statistical Manual of Mental Disorders \\
\hline GAR & Gemeenschappelijk Administratiekantoor \\
\hline Got & beroep gegrond verklaard \\
\hline $\mathrm{CO}^{-}$ & beroep ongegrond verkl aard \\
\hline GIT & Groninger Intelligentie Test \\
\hline GUD & Gemeenschappel ijke Medische Dienst \\
\hline LOAN & $\begin{array}{l}\text { Wet op de Inkomenswoorziening voor oudere en gedeelteli.jk } \\
\text { Arbe idsongeschikce werkloze Werknemers }\end{array}$ \\
\hline TOAZ & $\begin{array}{l}\text { Wet op de Inkomensvoorziening voor Oudere en gedecltelijk } \\
\text { Arbeidsongeschikte gewezen zelfstandigen }\end{array}$ \\
\hline IP & Inwallititeitspensioen \\
\hline IW & Invaliditeitswet \\
\hline INI & Interimwet. Invaliditeits renter rekkers \\
\hline MMP I & Minnesota Multiphasic Personality Inventory \\
\hline NIP & Nederlands Instituut van Psychologen \\
\hline NPV & Nederlandse Persoonlijkheids Vragenlijst \\
\hline NVM & Nederlandse verkorte MPI \\
\hline nww & nieuwe Werkloosheidswet \\
\hline oGt & overgenomen advies \\
\hline OG- & niet overgenomen advies \\
\hline PMT & Prestatie Motivatie Test \\
\hline PS & Pijnschal. \\
\hline RTM & Revalidatie Institut Muiderpoort \\
\hline VEVB & voor beroep vatbare beslissing \\
\hline VOFG & Vragenlijst woor Onderzoek van de Ervaren Gezondheidstoestand \\
\hline WAIS & Wechsler Adult Intelligence Scale \\
\hline Who & Wet op de Arbeidsongeschiktheidsverzekering \\
\hline ZABV & zelf-administrerende Bedrijfswereniging \\
\hline ZBV & Zelf-Beoordelings Vragenlijst \\
\hline $2 \mathrm{~W}$ & Ziekcewer \\
\hline
\end{tabular}


De schrijuer van dit proefschrife werd geboren op 6 april 1948 te Amersfoort.

In 1967 behalde $h$ ij het HBS-A-diplona an de Christelijke HBS Charlois te Rotterdarn.

Tijdens zijn studie in de psychologie aan de Universiteit yan Amsterdam behalde hij in 1970 het kandidaats-examen cum laude en werkce vervolgens als kandidats-assistent op de afdeling ontwikkelingspsychologie bij prof.dr. R. Vuyk.

In 1972 is hij als psycholong afgestudeerd (hoofdrichting ontwikkelingspsychologie; bijuak psychopathologie) en heeft zich post-doctoraal verder geschoold in de diagnostiek van de psychopathologie en chronische pijn. Van 1972 tot medio 1975 was hij als psycholoog werkzaam in IJmuiden bij de Stichcing voor Geestelijke Volksgezondheid te Noord-Holland.

$\mathrm{Na}$ twee jar als psycholoog-coördinator verbonden te zijn geweest aan de Onderwijsbegeleidingsdienst te Heemskerk, was hij van 1977 tot $\$ 981$ werkzaam op de Revalidatie-afdeling wan Ziekenhuis De Heel te Zaandam. Daar heeft hij als psycholoog-coördinator van de Arbeids functie Afdeling zich in het bijzonder met arbejdsrevalidatie beziggehouden.

In deze periode is hij wooritter geweest van de Werkgroep Revallatiepsychologen van het Nederlands Instituut van Psychologen.

Sinds 1981 is hij directeur van het Psychologisch Adwiesbureau Lancée te Alkmaar en Assen, waar psychologische onderzoeken worden verricht ten behoeve van de advies- en uitvoeringsorganen van de arbeidsongeschiktheidswetgeving, bedrijfsgezondheidsdiensten, juridische instanties en particuliere verzekeringsmatschappijen.

Hij is lid wan de Werkgroep Rapportage en de Sociale Wetgeving. 